\author{
UNIVERSIDADE DE SÃO PAULO \\ ECA | FAU | FFLCH | MAC \\ Pós-Graduação Interunidades em Estética e História da Arte
}

\author{
HELOISA PINTO URURAHY
}

\title{
MUSEUS NA INTERNET DO SÉCULO XXI: a caminho do museu ubíquo
}



HELOISA PINTO URURAHY

\section{MUSEUS NA INTERNET DO SÉCULO XXI: a caminho do museu ubíquo}

Dissertação apresentada à Pós-Graduação Interunidades em Estética e História da Arte, da Universidade de São Paulo, para obtenção do título de Mestre em Artes.

Orientador: Prof. Livre Docente Artur Matuck.

São Paulo

2013 
Autorizo a reprodução e divulgação total ou parcial deste trabalho, por qualquer meio convencional ou eletrônico, para fins de estudo e pesquisa, desde que citada a fonte.

Catalogação na Publicação

Serviço de Biblioteca e Documentação

Faculdade de Filosofia, Letras e Ciências Humanas da Universidade de São Paulo

$\mathrm{U} 82 \mathrm{~m}$

Ururahy, Heloisa Pinto

Museus na internet do século XXI: a caminho do

museu ubíquo / Heloisa Pinto Ururahy ; orientador

Artur Matuck. - São Paulo, 2013.

$133 \mathrm{f}$.

Dissertação (Mestrado) - Museu de Arte Contemporânea MAC/USP. Departamento de Pesquisa. Área de concentração: Estética e História da Arte.

1. Museus virtuais. 2. internet. 3. redes

sociais. 4. arte efêmera. 5. patrimônio imaterial. I. Matuck, Artur, orient. II. Título. 


\section{HELOISA PINTO URURAHY}

\section{Museus na internet do século XXI: a caminho do museu ubíquo}

Dissertação apresentada à Pós-Graduação Interunidades em Estética e História da Arte, da Universidade de São Paulo, para obtenção do título de Mestre em Artes.

Orientador: Prof. Livre Docente Artur Matuck.

\section{BANCA EXAMINADORA:}

Prof. Dr. Instituição:

Julgamento: Assinatura:

Prof. Dr. Instituição:

Julgamento: Assinatura:

Prof. Dr. Instituição: Julgamento: Assinatura: 



\section{AGRADECIMENTOS}

Agradeço,

Ao meu orientador, Prof. Artur Matuck, pela confiança, pela paciência e pela precisão nos comentários que me direcionaram durante todo o trabalho de pesquisa acadêmica.

Aos professores Carlos Zibel e Hugo Fortes, da banca de qualificação, pela disponibilidade e pelos comentários e sugestões fundamentais para o desenvolvimento da dissertação.

Aos professores e colegas das disciplinas cursadas, pelos excelentes espaços de aprendizagem e troca criados no ambiente da universidade.

Aos colegas orientandos do prof. Matuck, pelas parcerias em processos artísticos colaborativos dentro e fora das salas de aulas.

À amiga Maíra Vaz Valente, grande companheira de pesquisa e criação, pela investigação que realizamos juntas e que faz parte desse trabalho.

Aos amigos Débora e Rogério pela companhia durante o processo.

À minha família, minha mãe, meu pai, meu irmão, minha cunhada e minha madrinha, pelo apoio e estímulo incondicionais. 


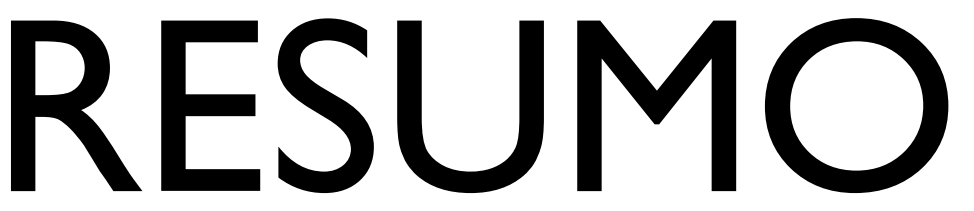

A pesquisa observa as novas relações de produção e difusão da arte que surgiram com a utilização da internet e das novas tecnologias, pelas instituições culturais, para a expansão de suas atividades. A investigação propõe que essa nova forma de comunicação pode unir o alcance das plataformas virtuais, a credibilidade de grandes centros artísticos e a força dos processos colaborativos de criação em rede para ampliar a propagação da arte e da cultura. O estudo pretende mostrar como museus, galerias e instituições culturais em geral, têm desenvolvido trabalhos na world wide web, desde o começo dos anos 90, de forma a ampliar o acesso do público, não apenas a seus acervos e exposições, mas também à possibilidade de criação conjunta do conhecimento museológico e de nossa herança cultural.

Através da observação dos conteúdos disponibilizados na rede por museus variados, nacionais e internacionais, relacionados a artigos sobre questões contemporâneas da museologia, são analisados como os objetivos das instituições artísticas quanto ao uso do ciberespaço têm evoluído. Há um crescente esforço em suprir as necessidades culturais dos novos espectadores da era conectada da internet. Hoje, modelos de exposições virtuais permitem que formatos de arte efêmera, como performances ou intervenções, possam efetivamente fazer parte dos espaços museológicos. Foi criada uma nova ligação com o visitante do museu, que pode estar em qualquer lugar do mundo e, utilizando redes sociais e mídias móveis, passa a ser criador e difusor de conteúdo, além de receptor. Por fim, há a reflexão sobre como, enquanto se adéquam às novas relações do homem com a arte e a cultura através do mundo virtual, as instituições devem se preocupar com a responsabilidade social e a democratização do acesso aos bens culturais por aqueles que ainda não tem contato frequente com as novas tecnologias.

PALAVRAS-CHAVE: Museus; galerias; museus virtuais; acervos digitais; internet; redes sociais; mídias móveis; gêneros artísticos; arte efêmera; difusão cultural; patrimônio imaterial; herança cultural. 


\section{ABSTRACT}

The research points the new relations of production and dissemination of art that emerge with the use of the Internet and new technologies, by cultural institutions to expand their activities. The research suggests that this new form of communication can put together the reach of virtual platforms, the credibility of major artistic centers and the strength of networks for collaborative creation processes, to enlarge the propagation of art and culture. The study aims to show how museums, galleries and cultural institutions in general, have developed activities on the world wide web since the early '90s, in order to increase public access, not only to their collections and exhibitions, but also to the possibility of joint creation of the museological knowledge and cultural heritage.

How the goals of art institutions in the use of cyberspace have evolved are analyzed through observation of the content provided on the net by various museums, national and international, related with articles about issues on contemporary museology. There is a growing effort to meet the cultural needs of the new spectators of internet connected age. Nowadays, virtual exhibitions models allow ephemeral art formats, such as performances or interventions, to effectively be part of the museum spaces. A new connection was created with the museum visitor, who can be anywhere in the world and, using social networks and mobile media, becomes a creator and disseminator of content, as well as a receiver. Finally, there is the observation on how, while adapting with the man's new relationship with art and culture through the virtual world, institutions should concern also about social responsibility and democratic access to culture for those who do not have frequent contact with new technologies.

KEYWORDS: Museums, galleries, virtual museums, digital archives, internet, social networks, mobile media, artistic genres, ephemeral art, cultural diffusion, intangible heritage, cultural heritage. 


\section{LISTA DE ILUSTRAÇÕES}

[Imagem 01] - Obra de Marcel Duchamp: La Boîte-en-Valise

[Imagem 02] - André Malraux com as ilustrações para Le Musée Imaginaire

[Imagem 03] - Frames do vídeo Luminare. Direção: John Sanborn e Dean Winkler

[Imagem 04] - Site do Museu de Arte Contemporânea de Niterói

[Imagem 05] - Site do Museu de Arte Contemporânea de São Paulo

[Imagem 06] - Site do Museu de Arte de São Paulo Assis Chateaubriand

[Imagem 07] - Site do Videomuseum

[Imagem 08] - Portal francês Joconde

[Imagem 09] - Página da Web Gallery of Art

[Imagem 10] - Páginas da Frick Art Collection

[Imagem 11] - Site Era Virtual Museus

[Imagem 12] - Pinacoteca do Estado de São Paulo no GoogleStreetView

[Imagem 13] - Página do Museum of Computer Art

[Imagem 14] - Site do Museu Virtual para a Arte Computacional

[Imagem 15] - Site do Dia Center for the Arts

[Imagem 16] - Site E.SPACE

[Imagem 17] - Site do ZKM Media Museum

[Imagem 18] - Página do Museo Virtual de Artes

[Imagem 19] - Site do Adobe Museum of Digital Media

[Imagem 20] - Site do Streaming Museum

[Imagem 21] - Página do Museum With no Frontiers

[Imagem 22] - Página MOMA Explore

[Imagem 23] - Página MOMA Multimidia

[Imagem 24] - Site do Guggenheim Museum

[Imagem 25] - Página Interact do site do Guggenheim - NY

[Imagem 26] - Página da Tate Gallery com recursos para crianças

[Imagem 27] - Página da Tate Gallery com recursos educativos

[Imagem 28] - Gráfico da evolução da Web

[Imagem 29] - Gráfico detalhado da evolução da Web

[Imagem 30] - Página no Twitter do MOMA - NY

[Imagem 31] - Página My Collection do MOMA - NY

[Imagem 32] - Página do Museu Guggenheim no Facebook

[Imagem 33] - Comunidade online Tate Collectives no site da Tate Gallery 
[Imagem 34] - BMW Tate Live no YouTube

[Imagem 35] - MOMA Screen Tests no Flickr

[Imagem 36] - Re: Contemplating the Void no Flickr (Guggenheim)

[Imagem 37] - YouTube Play, mostra bienal de vídeos online (Guggenheim)

[Imagem 38] - Maurizio Catellan: All App (Guggenheim)

[Imagem 39] - MOMA Iphone App

[Imagem 40] - Tate iPad App: Tate Guide to Modern Art Terms

[Imagem 41] - Interface do Museum App

[Imagem 42] - Mobile Online Museum of Contemporary Art

[Imagem 43] - The Widget Art Gallery

[Imagem 44] - Página da Gallery of Lost Art (Tate Gallery)

[Imagem 45] - Vídeo de Richard Serra: Television Delivers People (1973) no Ubuweb

[Imagem 46] - Canal de Dean Winkler no YouTube

[Imagem 47] - Site do Lin Hsin Hsin Art Museum

[Imagem 48] - Projeto One Hundred Boxes

[Imagem 49] - Site do The Mini Museum of the XXI Century Arts

[Imagem 50] - Página da 700MB Gallery

[Imagem 51] - Projeto The Museum of Online Museums

[Imagem 52] - Site do projeto da Intel: The Museum of Me

[Imagem 53] - Página do perfil do Instagrafite no Instagram

[Imagem 54] - Página de artista no site CargoCollective

[Imagem 55] - Perfil do SFMOMA na rede social Pinterest

[Imagem 56] - Página inicial do site Delicious

[Imagem 57] - Museu Virtual da Intervenção Urbana SP no Delicious

[Imagem 58] - Museu Virtual da Intervenção Urbana SP no Pinterest

[Imagem 59] - Museu Virtual da Intervenção Urbana SP no Pinterest - Viajou Sem Passaporte

[Imagem 60] - Museu Virtual da Intervenção Urbana SP no Pinterest - Viajou Sem Passaporte

[Imagem 61] - Museu Virtual da Intervenção Urbana SP no Pinterest - Manga Rosa

[Imagem 62] - Museu Virtual da Intervenção Urbana SP no Pinterest - Manga Rosa

[Imagem 63] - Museu Virtual da Intervenção Urbana SP no Pinterest - 3NÓS3

[Imagem 64] - Museu Virtual da Intervenção Urbana SP no Pinterest - 3NÓS3

[Imagem 65] - Museu Virtual da Intervenção Urbana SP no Delicious

[Imagem 66] - Museu Virtual da Intervenção Urbana SP no Delicious

[Imagem 67] - Site do Museu da Pessoa de São Paulo

[Imagem 68] - Projeto Cleveland Historical

[Imagem 69] - Website da Wikipedia

[Imagem 70] - Site da Virtual Museum Transnational Network

[Imagem 71] - Site TourSphere 


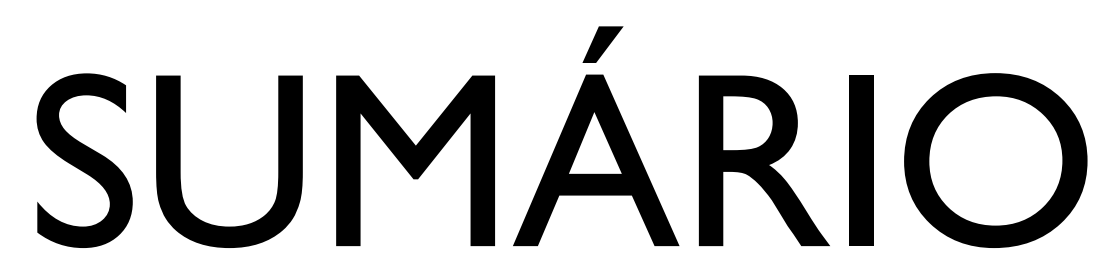

> INTRODUÇÃO …………………………………..... 15

I BREVE HISTÓRICO DO MUSEU ELETRÔNICO. p. 20

I.I Primórdios do museu 'sem paredes' ................................................... p. 20

I.2 O site museográfico como sistema de divulgação e acervo online ..... p. 25

I.3 O site do museu como repositório de obras para a web ........................ p. 35

I.4 Os museus virtuais e as exposições digitais ............................................. p. 42

\section{MUSEUS E A TRANSFORMAÇÃO DA WEB ............ p. 48}

2.I O museu on-line como extensão do museu off-line ................................... p. 48

2.2 A evolução da Internet e da informação na web ....................................... p. 56

2.3 A presença dos museus nas redes sociais ................................................... p. $6 \mathrm{I}$

2.4 Mídias móveis dentro e fora dos museus ............................................ p. 70

2.4.I Os dispositivos como extensões do homem .................................................... p. 70

2.4.2 Aplicativos móveis on-site e off-site ............................................................... p. 72 


\section{DIRETRIZES PARA UM MUSEUVIRTUAL CONTEMPORÂNEO}

3.I A web como espaço museográfico da arte efêmera, do colecionismo e da personalização

3.2 Projeto experimental:

Museu Virtual da Intervenção Urbana em São Paulo p. 90

3.2.I Redes sociais como plataforma para o colecionismo e a personalização na web p.90

3.2.2 Museu Virtual da Intervenção Urbana SP: o uso dos sites Delicious e Pinterest como espaço museológico p. 96

4 MUSEUS, INTERNET E A CRIAÇÃO COLETIVA DA HERANÇA CULTURAL p. 105

4.I $\bigcirc$ papel da internet na preservação do patrimônio imaterial p. 105

4.2 Criação coletiva de uma herança cultural global p. 112

4.2.I Criações colaborativas e patrimônio cultural p. 112

4.2.2 A democratização dos meios de produção e difusão da cultura p. 115

$>$ CONSIDERAÇÕES FINAIS: PERSPECTIVAS PARA OS MUSEUS NA INTERNET.

$>$ APÊNDICE p. 122

$>$ REFERÊNCIAS BIBLIOGRÁFICAS 
"O futuro é tudo que os museus podem nos proporcionar. Sabemos agora que não há história absoluta, que o passado é escrito no presente." [Roy Ascott, 1996] 


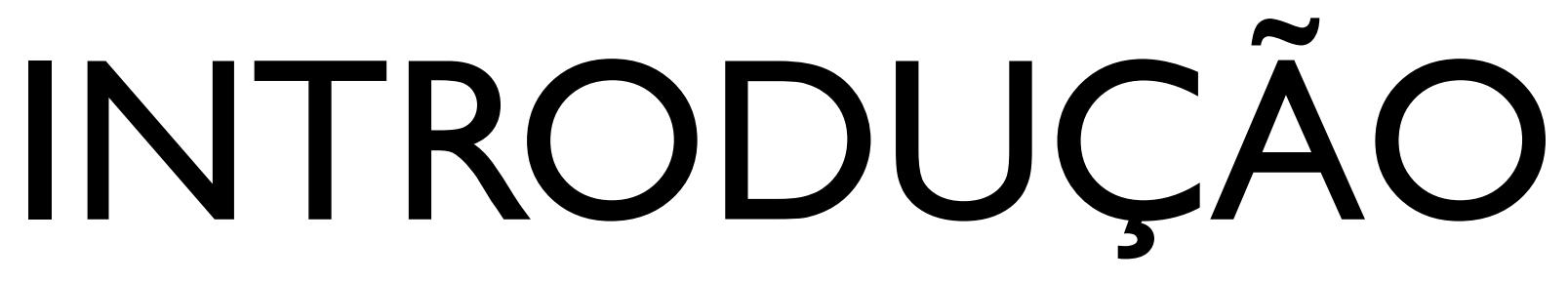

Computadores e internet são tão presentes no cotidiano atual que esquecemos o que seria o mundo sem a world wide web. A rede antes era considerada um mundo a parte e tratada, até os anos 90, como uma 'segunda vida'. Hoje, ela é a extensão natural do dia a dia da maioria dos cidadãos nas grandes cidades de todo o planeta. Para as novas gerações, principalmente, já não há mais distinção entre formas de comunicação online e offline, entre relações virtuais e o contato humano direto.

Esses novos hábitos de ser e viver, totalmente integrados às mais avançadas tecnologias, geraram outro modo de interação entre as pessoas e o mundo ao seu redor. Muito mudou, além das relações sociais - pessoais e profissionais - mudaram também, as formas de contato que se tem com a informação e a cultura. Hoje, espaço e tempo se confundem. Através da internet, pessoas espalhadas por todo o globo terrestre podem ter acesso aos mesmos conteúdos a qualquer hora e lugar.

O uso das novas tecnologias na difusão cultural ainda é um processo em constante evolução, acompanhado há algum tempo por acadêmicos e estudiosos. Para García Canclini, antropólogo argentino, "as fusões multimídia e as concentrações empresariais na produção de cultura correspondem, no consumo cultural, à integração de rádio, televisão, música, notícias, livros, revistas e internet. Devido à convergência digital destes meios, se reorganizam os modos de acesso aos bens culturais e às formas de comunicação" ${ }^{1}$. Ele completa que, para atender aos novos espectadores, todas as instituições, culturais ou não, tiveram que se reorganizar, seguindo novas regras de marketing, distribuição internacional e difusão por meios eletrônicos de comunicação: "nem os hábitos atuais dos leitores-espectadores-

I GÁRCIA CANCLINI, Néstor. Lectores, espectadores e internautas. Barcelona, España: Editoral Gedisa, 2007, p. 49. [tradução livre] 
internautas, nem a fusão de empresas que antes produziam de forma separada cada tipo de mensagem, ainda permite conceber como ilhas separadas os textos, as imagens e sua digitalização" ${ }^{2}$.

O sociólogo espanhol, Manuel Castells, apresenta a ideia de que utilizando novas tecnologias de informação e de comunicação, "a articulação entre o real e o virtual, o físico e o simbólico, está desenvolvendo cada vez mais novos híbridos culturais que geram a renovação da comunicação cultural no mundo" ${ }^{3}$. Em seguida, ele afirma que a mescla entre tecnologia e cultura tem se tornado a regra, e não a exceção, nas atividades dos museus hoje em dia ${ }^{4}$.

As instituições culturais logo perceberam a importância de se atualizarem quanto às novas formas de comunicação, e começaram pela utilização da internet para divulgar suas atividades. Hoje, uma série de conteúdos, antes somente disponíveis dentro do espaço físico de bibliotecas e museus, agora podem ser acessados e conhecidos, a qualquer momento, em quase todo o planeta. Essas organizações que muitas vezes mantinham seus acervos fora de exposição, em um esforço de preservar obras frágeis ou mesmo raras, descobriram na web uma forma de disponibilizar suas coleções inteiras ao público.

A percepção de um museu que pode estar em qualquer lugar, e em todos os lugares, deixa de ser uma visão utópica. O museu ubíquo passa a ser um progresso natural e possível dos acervos de nosso patrimônio cultural. A presença de museus e do trabalho museológico na internet merece especial atenção, pois demonstra grande esforço por parte dessas instituições em se adaptar para preservar nossa herança cultural, acompanhando a constante evolução da sociedade.

2 GÁRCIA CANCLINI, 2007, p. 50. [tradução livre]

3 CASTELLS, Manuel. Museums in the information era: cultural connectors of time and space. In: Parry, Ross (ed.) Museums in a age digital. USA: Routledge, 2010, p. 427. [tradução livre]

4 Idem, 2010 , p. 427. 
O conceito do que seria o museu virtual ainda é muito vago, está em endereços eletrônicos muitas vezes que pouco tem em comum, e se refere praticamente a qualquer tipo de reunião de materiais ${ }^{5}$. São muitas as formas nas quais se apresenta o trabalho museográfico na internet, desde websites de grandes museus, passando por espaços e obras de arte criados apenas virtualmente, e até pequenas coleções digitalizadas e postadas por indivíduos comuns. Por isso, se faz necessária a apresentação da extensa nomenclatura difundida para tratar do assunto: 'cibermuseu', 'museu virtual', 'museu eletrônico', 'museu digital', 'museu online', 'museu na internet', 'web-museu', 'e-museu', entre outros.

Apesar do uso indiscriminado de todos esses termos, praticamente como sinônimos, e de alguns estudos tentarem levar em consideração etimologia, terminologia e tipologia para separar as suas funções. Os nomes preferidos ao longo dessa pesquisa serão:

Museu online: no qual a própria palavra 'online' sugere um contraponto a uma versão offline e deve ser usada, em geral, para museus que possuem também um prédio físico;

Museu virtual: que traz a palavra derivada do latim virtus, que significa excelência e virtude - este deve ser usado para conteúdos que foram programados e funcionam apenas na internet.

Museu na internet, Museus na web ou Web-museus: que cobrem qualquer manifestação museológica que possa existir na internet ${ }^{6}$.

A investigação observará os variados tipos de manifestação museológica presentes na internet, sejam elas, de grandes instituições, pequenas galerias ou iniciativas pessoais. O maior foco recai sobre os museus de arte moderna e contemporânea e os

5 HUHTAM0, Erkki. On the origins of the virtual museum. In: Parry, Ross (ed.) Museums in a age digital. USA: Routledge, 2010, p. I2I.

6 SVILICIC, Niksa. Creation and Typology Definition of the Museum on the Internet. Croatian Audiovisual Center, Zagreb, Croácia, 2010. 
projetos de artistas, devido a seu natural posicionamento de vanguarda no uso das novas tecnologias. No entanto, a pesquisa não é excludente e também cita museus cujo acervo não é exatamente relacionado às artes visuais, mas que representam potentes abrigos de herança cultural.

Grande parte do material analisado encontra-se online, em web-museus, webgalerias e outros tipos de websites criativos, e não são transponíveis ao meio impresso. Os exemplos citados são, em sua maioria, páginas com diversas camadas de informação constantemente atualizadas, e devem ser visitadas para seu melhor entendimento e contextualização. A leitura do trabalho transita no 'interespaço' entre o impresso e o virtual. Por isso, junto com versão encadernada do texto, há também uma versão e-book, com hiperlinks ativos, conectando o leitor aos ciberespaços relacionados na pesquisa. 
"O Telemuseu: Você desfrutará do privilégio de selecionar imagens compativeis com o seu humor, ou que atendam as demandas de qualquer ocasião especial. Através do ecrã de seu Teleset você compartilhará o domínio dos maiores tesouros da arte do mundo." [Frederick Kiesler, 1926-1930] 


\section{BREVE HISTÓRICO DO MUSEU ELETRÔNICO}

\section{I.I PRIMÓRDIOS DO MUSEU 'SEM PAREDES'}

A ideia de um museu transportável e onipresente não aparece apenas com o surgimento da internet. Referências a um acervo da cultura global transportável e acessível a população mundial, permeiam todo o século XX antes dos primeiros embriões da rede de computadores.

Por volta dos anos 20, artistas da avant-garde, com o avanço do uso das novas tecnologias de seu tempo, fotografia e filme, sentiam a necessidade de mudanças no conceito e papel da arte na sociedade, e de um novo pensamento da relação entre espaços de exibição e espectadores. A arte baseada nesses novos suportes não seria facilmente inserida nas instituições culturais da época, e por consequência, uma parte essencial da atividade dos modernistas era buscar novos meios de exibir suas obras ${ }^{7}$.

Visionários como Moholy-Nagy e Herbert Bayer, viam o projeto de exibição das obras como mais um novo meio a ser desenvolvido, e imaginavam a possibilidade de 'galerias domésticas'. Entre 1926 e 1930, o artista Frederick Kiesler vislumbra um Telemuseum, no qual as paredes de nossas casas teriam painéis sensíveis que receberiam imagens transmitidas a elas. Já o dadaísta Marcel Duchamp preconizava um 'museu portátil' carregando pequenas réplicas e reproduções de seus trabalhos em uma maleta, obra denominada La bôite-en-valise [imagem 01] ${ }^{8}$.

7 HUHTAMO, 2010, p. 124.

8 Idem, 2010, p. 123-129. 
Ainda nos anos 30, o romancista H.G. Wells já havia apresentado o termo 'world brain' - em português 'cérebro mundial' - em uma série de artigos e palestras. Ele imaginava um banco de dados global construído com microfilmes e disponível para qualquer estudante do mundo acessá-lo através de projetores em suas próprias casas $^{9}$.

Muitas foram as ideias que prepararam o caminho para o conceito de museu virtual, mas talvez o mais lembrado seja o livro de André Malraux, 0 museu imaginário ${ }^{10}$. Ele foi escrito após o importante ensaio de Walter Benjamim em 1936, A obra de arte na era de sua reprodutibilidade técnica ${ }^{11}$, que nos apresenta a fotografia e sua possibilidade de reprodução mecânica infinita, como o momento de perda da 'aura' da obra de arte, já não haveria mais diferença entre original e cópia. Em 1947, a ideia de Malraux para um 'museu imaginário sem paredes' surge pela possibilidade de reprodução fotográfica. Fotos de obras de arte poderiam ser agrupadas de diferentes formas e levadas aonde fossem necessárias [imagem 02].

Nos anos 40, o engenheiro americano Vannevar Bush criou um serviço de manipulação de informações chamado Memex que permitia que o usuário armazenasse e recuperasse arquivos em um sistema não linear, princípios que hoje são tratados como o começo do hipertexto ${ }^{12}$. Ele também permitia a indexação associativa, conceito que é utilizado até hoje em buscas na web. Mais tarde, já nos anos 60, o filósofo americano Ted Nelson, considerado pioneiro no campo da tecnologia da informação, desenvolveu um projeto chamado Xanadu, que é considerado o percursor do hipertexto de hoje, seu objetivo era criar uma rede entre computadores com uma interface muito simples ${ }^{13}$.

9 HUHTAM0, 2010 , p. I3I.

10 MALRAUX, Andre. 0 museu imaginário. Lisboa: Edições 70, 2000.

II BENJAMIN, Walter. A obra de arte na era de sua reprodutibilidade técnica. In: Magia e técnica, arte e politica: ensaios sobre literatura e história da cultura. São Paulo: Brasiliense, 1994.

12 HUHTAMO, 2010 , p. 123.

13 Idem, p. 122. 
Na década de 80, prévias do que seria um museu virtual já haviam sido testadas. 0 trabalho em video chamado Luminare, realizado em 1986, de John Sanborn e Dean Winkler ${ }^{14}$, começa com um passeio virtual através de uma paisagem eletrônica com dançarinos e objetos digitais. Em seguida, atravessam-se corredores com representações de quadros apresentando a história da arte em um modelo de galeria virtual [imagem 03] ${ }^{15}$.

Durante todo os anos 90, muitos museus já usavam o hipertexto multimídia na confecção de CD-ROMs para difusão de seus acervos. Inseridos em computadores pessoais, os CDs traziam fotos de obras digitalizadas, exercícios interativos e passeios virtuais em simulações de espaços de exposições de três dimensões. Os discos eram disponibilizados nas lojas físicas dos museus como souvenir para seus visitantes e também encontravam lugar em bibliotecas escolares como material didático para professores e alunos que não teriam acesso aos museus pessoalmente ${ }^{16}$.

Foi no ano de 1990, que o britânico Tim Berners-Lee, considerado o fundador da world wide web, inventa o HTML (Hyper Text Markup Language), usado para definir a estrutura e o layout de webpages ${ }^{17}$. No entanto foi no Japão de 1991, ainda não conectado à Internet, que surgiu a primeira exposição discutindo a exibição de obras de arte a distância. O projeto 0 museu dentro da rede de telefonia era acessado remotamente via telefone, fax e um tipo de rede computacional. Quatro anos depois se seguiu uma nova versão da exposição chamada $O$ museu dentro da rede, já alocada na própria Internet ${ }^{18}$.

Nos anos que se seguiram, a presença de museus na rede mundial de computadores apenas cresceu. Em um primeiro momento, fazendo parte essencial dos planos de marketing e divulgação dessas instituições, para que em seguida se transformassem em um de seus melhores trunfos na ampliação do cumprimento de suas missões básicas: coleção, preservação, investigação e exposição.

I4 LUMINARE. Vídeo, 6'54", 1986, direção: John Sanborn e Dean Winkler (HUHTAMO, 2010 p. 132).

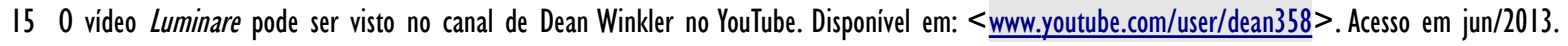

16 HUHTAMO, 2010, p. 122.

17 THE BIG INTERNET MUSEUM. Disponivel em: < www.thebiginternetmuseum.com>. Acesso em maio/2013.

18 HUHTAMO, 2010, p. 122. 


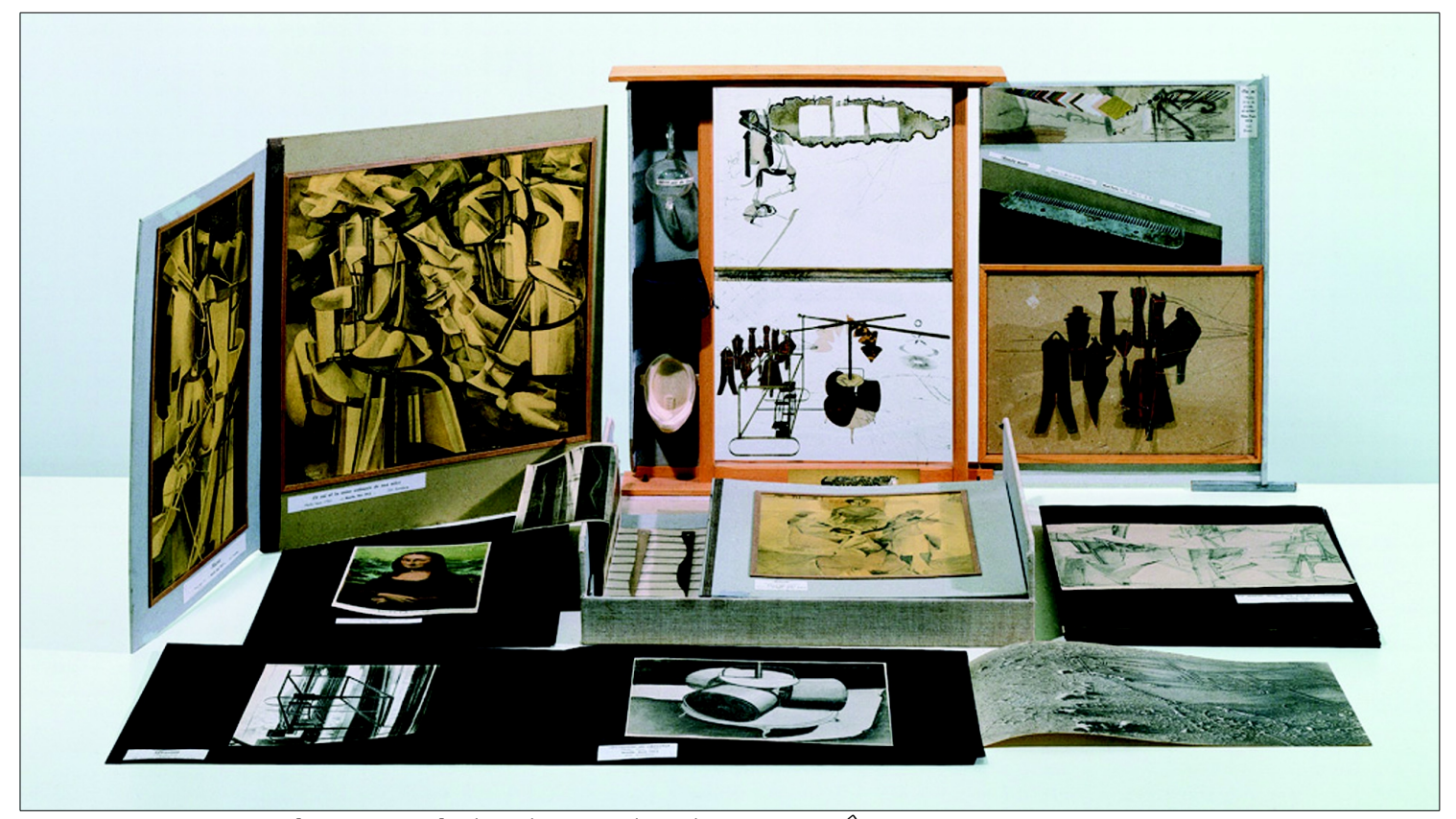

[Imagem 01] Obra de Marcel Duchamp: LA BOÎTE-EN-VALISE, 1938-1941.

Fonte: <www. 1fmediaproject.net/2011/07/22/site-inspection-the-museum-on-the-museum-ludwig-museum-budapest>

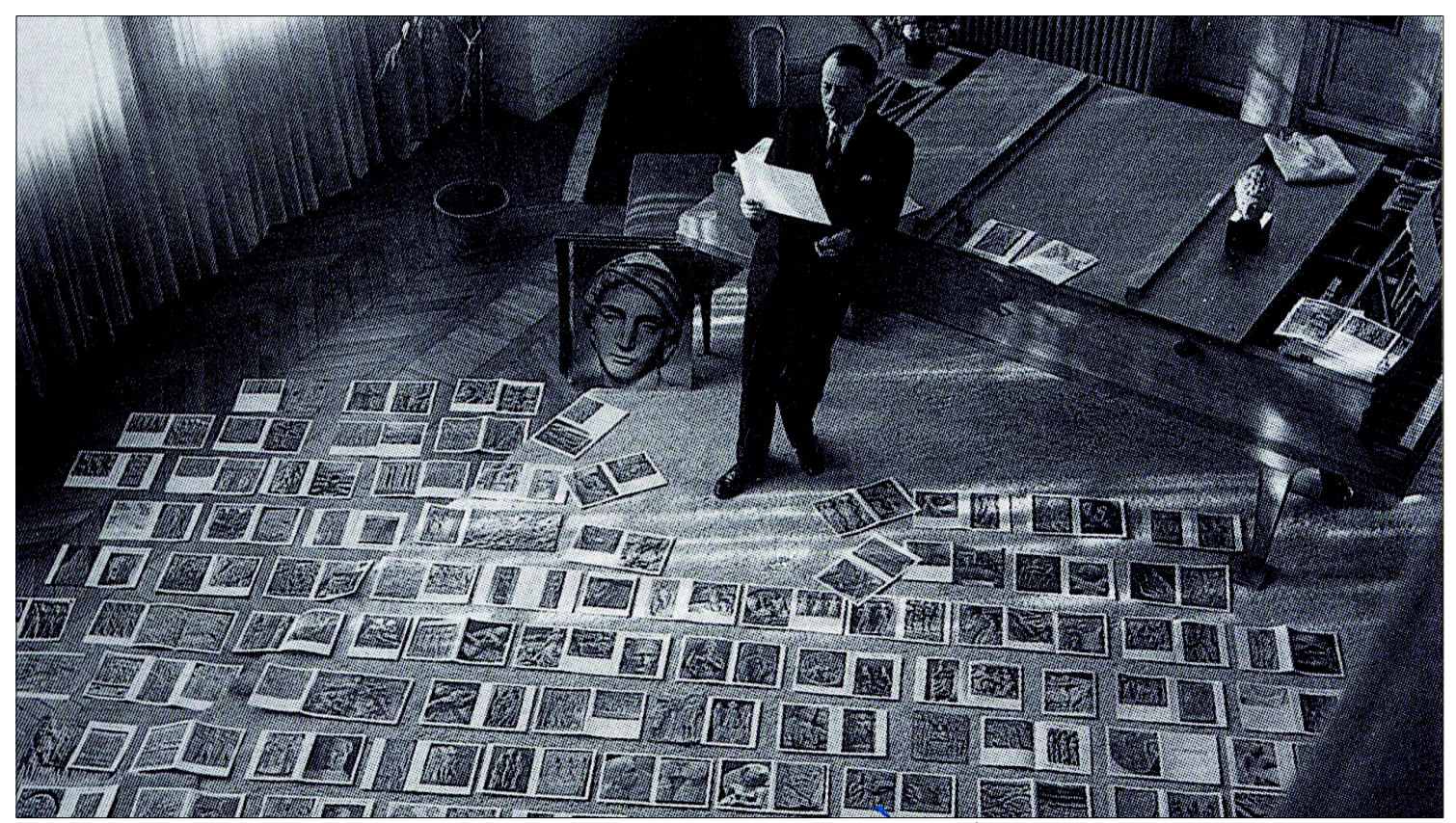

[Imagem 02] André Malraux, com as ilustrações para LE MUSÉE IMAGINAIRE, 1947.

Fonte: $\leq$ www.grupaok.tumblr.com/post/18739422082/andre-malraux-with-the-illustrations-for-le-musee $>$ 


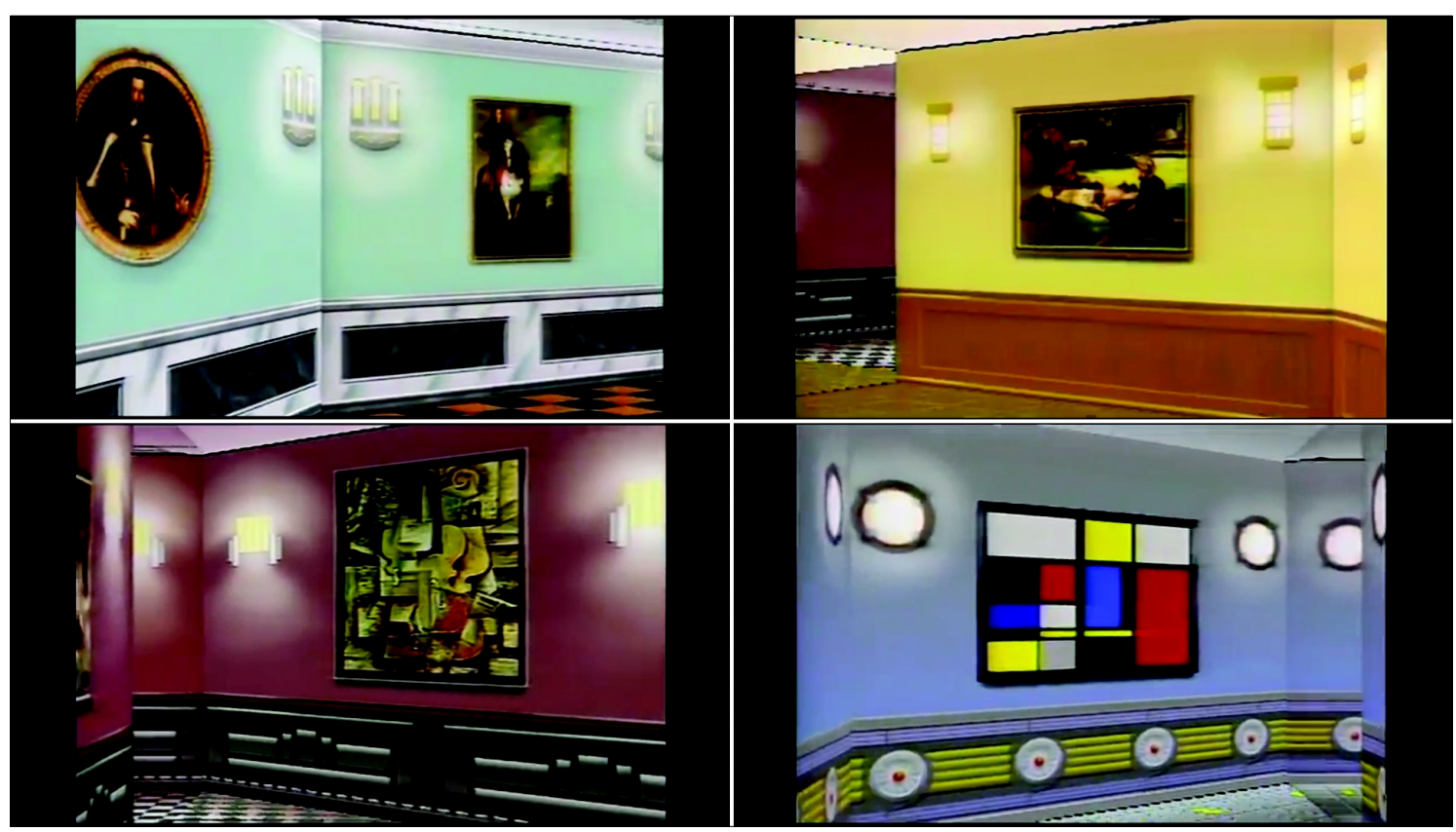

[Imagem 03] Frames do vídeo LUMINARE. Direção: John Sanborn e Dean Winkler. (Vídeo, 6'54", 1986). Fonte: $<$ www.youtube.com/user/dean358 $>$. Acesso em jun/2013. 


\title{
I.2 O SITE MUSEOGRÁFICO COMO SISTEMA DE DIVULGAÇÃO E ACERVO ONLINE
}

\begin{abstract}
Atualmente, alguns dos mais importantes museus conhecidos se destacam com páginas web ricas em conteúdos e formatos inovadores e interatividade multidirecional. No começo dos anos 90 aparecem os primeiros softwares de navegação ${ }^{19}$ e logo as grandes instituições artísticas começam a criar seus primeiros sites na internet. A princípio, seus maiores objetivos estavam focados somente na publicidade e divulgação de suas atividades a um número maior de pessoas além da comunidade localizada a sua volta e de seus visitantes habituais.
\end{abstract}

Nesta primeira fase dos museus na web, as próprias instituições, e em especial seus departamentos de ação cultural e educacional, identificam que suas funções primordiais haviam aumentado, aproveitando a potencialidade difusora da internet. Às tradicionais atribuições de coleção, preservação, investigação e exposição, acrescentar-se-iam os novos deveres de educação e comunicação. Para a acadêmica espanhola Bellido Gant, a rede vinha para permitir que se superasse o afastamento geográfico, facilitando o acesso individual e descentralizado do público com reproduções eletrônicas de obras de arte, facilitando a sua contemplação de maneira não presencial ${ }^{20}$.

As páginas web dos museus, até então, contentavam-se em disponibilizar informações sobre as atividades e o que mais houvesse em seu espaço físico. Encontrávamos nesses sites, por exemplo, a sua localização, preços, horários e serviços, parte ou toda coleção digitalizada, históricos das instituições, programação e calendários, publicações, loja virtual, departamento de imprensa e informações sobre programas de difusão e educação presenciais. Havia ainda, alguns tipos de serviços bidirecionais, que permitiam o contato do usuário com a empresa, como listas e

190 primeiro software de navegação popularmente conhecido foi lançado em 1994 com 0 nome Mosaic Netscape 0.9, posteriormente mudado para Netscape Navigator (THE BIG INTERNET MUSEUM. Disponivel em: <www.thebiginternetmuseum.com>. Acesso em maio/2013).

20 BELLIDO GANT, Maria Luisa. Arte, museos y nuevas tecnologías. Gijón, España: Ediciones Trea, 200I, p. 233. 
fóruns de discussão, bases de pesquisa, e-mail para a gerência e questionários de sugestões ou satisfação. Como aponta Bellido Gant:

"os museus converteram a internet em um substituto das páginas tradicionais de seus boletins e publicações periódicas, folhetos e catálogos, mas com a grande vantagem de possibilitar uma difusão em âmbito global. (...) Os boletins eletrônicos estão à disposição de qualquer um na rede, não possuem custo de impressão e distribuição e permitem sua atualização no mesmo ritmo com que se produzem as notícias" ${ }^{21}$.

Como exemplos de websites de museus que mantiveram por um longo tempo esse padrão da primeira fase da utilização da internet, podemos usar as páginas de algumas importantes instituições brasileiras ainda no começo desta década. No site do Museu de Arte Contemporânea de Niterói $i^{22}$, até julho de 2011, encontrávamos apenas uma barra de menu com as seguintes opções: história, visitação, arquitetura, exposições, acervo, programação, ações educativas, biblioteca online, publicações, parceiros e contato [imagem 04]. Na página do Museu de Arte Contemporânea de São Paulo ${ }^{23}$, na mesma época, observávamos as possibilidades de navegação: institucional, programa acadêmico, acervo, exposições, cursos, eventos e biblioteca [imagem 05]. Já o Museu de Arte de São Paulo ${ }^{24}$, ainda apresenta uma página bastante informativa, com links para acervo, exposições, institucional e informações gerais, e ainda em uma barra de opções mais escondida: educativo, biblioteca, escola, eventos, loja, parcerias, imprensa e programação mensal [imagem 06$]^{25}$.

Através desses primeiros esforços, as instituições conseguem ampliar a divulgação e promoção de suas coleções, exposições, programas e atividades, tanto para o público local, como também para um público internacional antes não atingido; e ainda aproximar-se mais de seus usuários pelos canais de comunicação direta, como fóruns de discussão e e-mail. A internet afeta, primeiramente, a projeção externa do museu,

21 BELLIDO GANT, 200I, p. 23I-232. [tradução livre]

22 MUSEU DE ARTE CONTEMPORÂNEA DE NITERÓl. Disponivel em: < www.macniteroi.com.br>. Acesso em jul/2012.

23 MUSEU DE ARTE CONTEMPORÂNEA DE SÃO PAULO, MAC-USP. Disponivel em: <www.mac.usp.br>. Acesso em jul/2012.

24 MUSEU DE ARTE DE SÃO PAULO ASSIS CHATEAUBRIAND, MASP. Disponivel em: < www.masp.art.br>. Acesso em jul/2013.

25 Ao término dessa dissertação, em julho de 2013 , todas as instituições já dispunham de sites um pouco mais atualizados às demandas atuais, contando com pelo menos alguma ligação externa a blogs, podcasts e redes sociais, como será visto mais adiante no texto. 
melhorando o acesso a informação, ao catálogo virtual e o enlace a recursos externos, além de favorecer o desenvolvimento de novas técnicas de mercado que aumentam o número de visitantes reais, e a aparição de novas atividades que geram novas demandas ao local $^{26}$.

Essas atividades iniciais dos museus na rede priorizavam a divulgação de informações esperando uma possível visita ao museu físico, funcionando como um catálogo eletrônico que promovia a democratização cultural com a exposição, divulgação e promoção da instituição e seus produtos na rede. Ainda, os museus se viram com a possibilidade de conectar seus acervos, facilitando a busca do usuário e o acesso a conteúdos separados fisicamente, mas unidos em catálogos virtuais gerais.

Nesse exemplo, temos o Videomuseum ${ }^{27}$, site que reúne 59 museus e coleções públicas francesas de arte moderna e contemporânea em uma mesma base de dados, concebendo a ideia de um espaço museológico interconectado e integrando variadas coleções em um espaço online comum. A organização iniciou suas atividades em 1991 gravando seu acervo em videodiscos, um tipo de mídia que precedeu o DVD, e que inspirou o nome do grupo. Em 1998, a instituição transferiu sua base de dados para a internet [imagem 07]. Ainda na França, a catalogação unificada de obras de museus públicos e privados foi iniciada em 1975, em um banco de dados chamado Joconde, em referência ao nome francês da obra de arte mais famosa situada naquele país, a Mona Lisa de Leonardo Da Vince. A base de dados Joconde é mantida pelo Ministério da Cultura da França e foi transferida para a internet em 1995. Ela possui cerca de 500 mil objetos catalogados, vindos em sua maioria de museus de belas artes, artes decorativas e arqueologia [imagem 08]. Um caso ainda importante foi a criação em 1996 da Web Gallery of Art $^{28}$. Iniciada por dois pesquisadores húngaros, o site se apresenta como um museu eletrônico e uma grande base de dados da arte europeia entre os séculos XI e XIX [imagem 09].

26 (Rosario López de Prado, 2000-200I) in: BELLIDO GANT, 200I. p. 23I.

27 VIDEOMUSEUM. Disponivel em: <www.videomuseum.fr >. Acesso em jul/2012.

28 WEB GALLERY OF ART. Disponivel em: < www.wga.hu >. Acesso em jun/2013. 
Outro derivado comum à presença dos museus na rede em sua primeira fase foi o desenvolvimento do chamado 'passeio virtual'. Muitos museus dedicaram grande parte de seus esforços à criação de visitas digitais imersivas. O museu é apresentado através de fotos estáticas, coladas umas às outras, formando um ambiente tridimensional na tela do computador. Um dos primeiros espaços a utilizar esse tipo de apresentação foi a Frick Art Collection ${ }^{29}$ de Nova York, que já contava com uma visita virtual em seu site desde 1998 [imagem 10].

Na missão de difundir acervos únicos e ampliar o alcance educativo das instituições culturais, a possibilidade de uma imersão virtual nas dependências de museus inacessíveis a grande parte da população, é vista como uma forma de democratizar o contato com a informação através do acesso remoto pela internet. A evolução de softwares específicos para esse tipo de exibição na rede se manteve constante. No Brasil, temos um belo exemplo de catálogo de 'passeios virtuais' no site Era Virtual Museus $^{30}$. Iniciado em 2008 e lançado em 2010, a página apresenta a possibilidade de visitações virtuais imersivas a acervos e exposições permanentes e/ou temporárias de 17 instituições brasileiras, entre as quais, o Museu Nacional de Artes e Ofícios de Minas Gerais e o Museu da República no Rio de Janeiro [imagem 11].

O computador começa a fornecer novas formas de contato com as informações museológicas, que passam a ser experimentadas de outros modos além da tradicional visita ao prédio do museu. O pesquisador italiano Andre Bandelli define isso como "dar de volta o controle ao espectador" 31 . O passeio do visitante pelo site do museu seria equivalente a andar pelos corredores do lugar real e parar diante de seus pontos de maior interesse. Com a vantagem de que no site, ainda recebemos informações extras sobre o mesmo contexto ${ }^{32}$.

29 THE FRICK COLLECTION. Disponivel em: <www.frick.org > Acesso em jun/2013.

30 ERA VIRTUAL MUSEUS. Disponivel em: < www.eravirtual.org >. Acesso em jul/2013.

31 BANDELLI, Andrea. Virtual spaces and museums. In: Parry, Ross (ed.) Museums in a age digital. USA: Routledge, 2010, p. 150. [tradução livre]

32 Idem, p. I5I. 
Atualmente, temos um grande exemplo da tentativa de levar os museus para dentro dos computadores pessoais no Google Art Project ${ }^{33}$. Através da tecnologia do Google Street View, o internauta pode visualizar o interior de alguns dos mais importantes museus do mundo através de imagens de alta resolução. Além da possibilidade de zoom em cada obra, o site fornece informações extras sobre as peças expostas, relaciona outras obras daquele autor e oferece vídeos sobre o mesmo tema. O espaço permite salvar imagens escolhidas, montando sua própria coleção para possível compartilhamento com amigos. A ideia é que em pouco tempo, essa transmissão de imagens, do espaço do museu para o usuário no computador remoto, seja feita ao vivo.

Até o momento, fazem parte do projeto apenas duas instituições brasileiras, a Pinacoteca do Estado de São Paulo, com 98 obras disponíveis, e o Museu de Arte Moderna de São Paulo, com 89 obras. A curadoria das obras disponibilizadas é feita pelos próprios museus, que ainda podem escolher uma obra para ser digitalizada em altíssima resolução (7 bilhões de megapixeis). No caso dos museus brasileiros, os escolhidos foram o painel da dupla osgemeos do MAM-SP e o quadro Saudade, de Almeida Júnior, do acervo da Pinacoteca ${ }^{34}$ [imagem 12].

33 GOOGLE ART PROJECT. Disponivel em: < $<w w . g 00 g$ leartproject.com>. Acesso em: jul/2012.

34 MAGENTA, Matheus. Google Art Proiect libera visita virtual à Pinacoteca e ao MAM. Folha online, 03 abr. 2012. Disponivel em: $<$ http://wwwl.folha.uol.com.br/ilustrada/l071082-google-art-project-libera-visita-virtual-a-pinacoteca-e-ao-mam.shtml>. Acesso em abril/2012. 


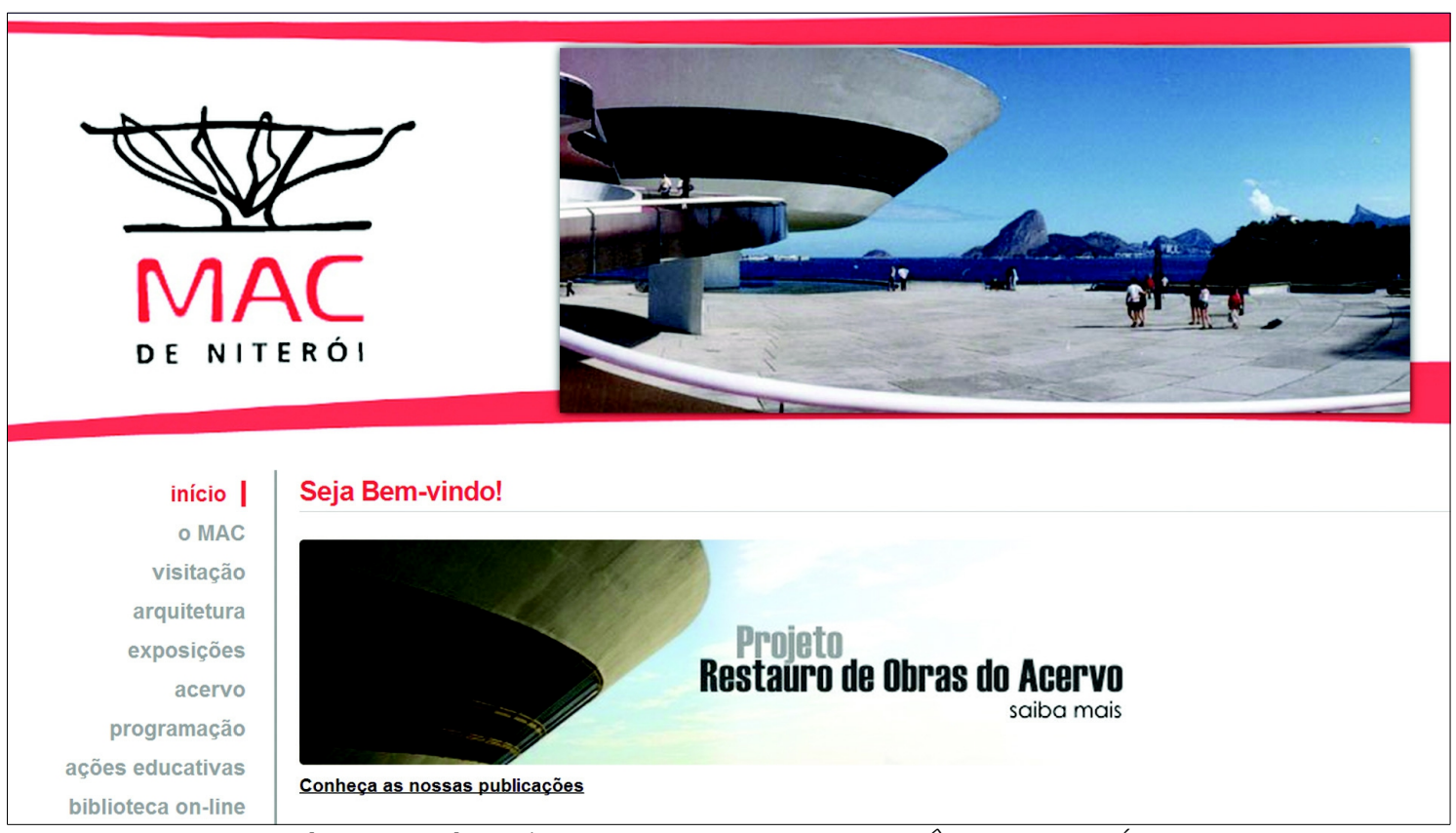

[imagem 04] Site do MUSEU DE ARTE CONTEMPORÂNEA DE NITERÓI. Fonte: $\langle w w w . m a c n i t e r o i . c o m . b r\rangle$. Acesso em jul/2013.

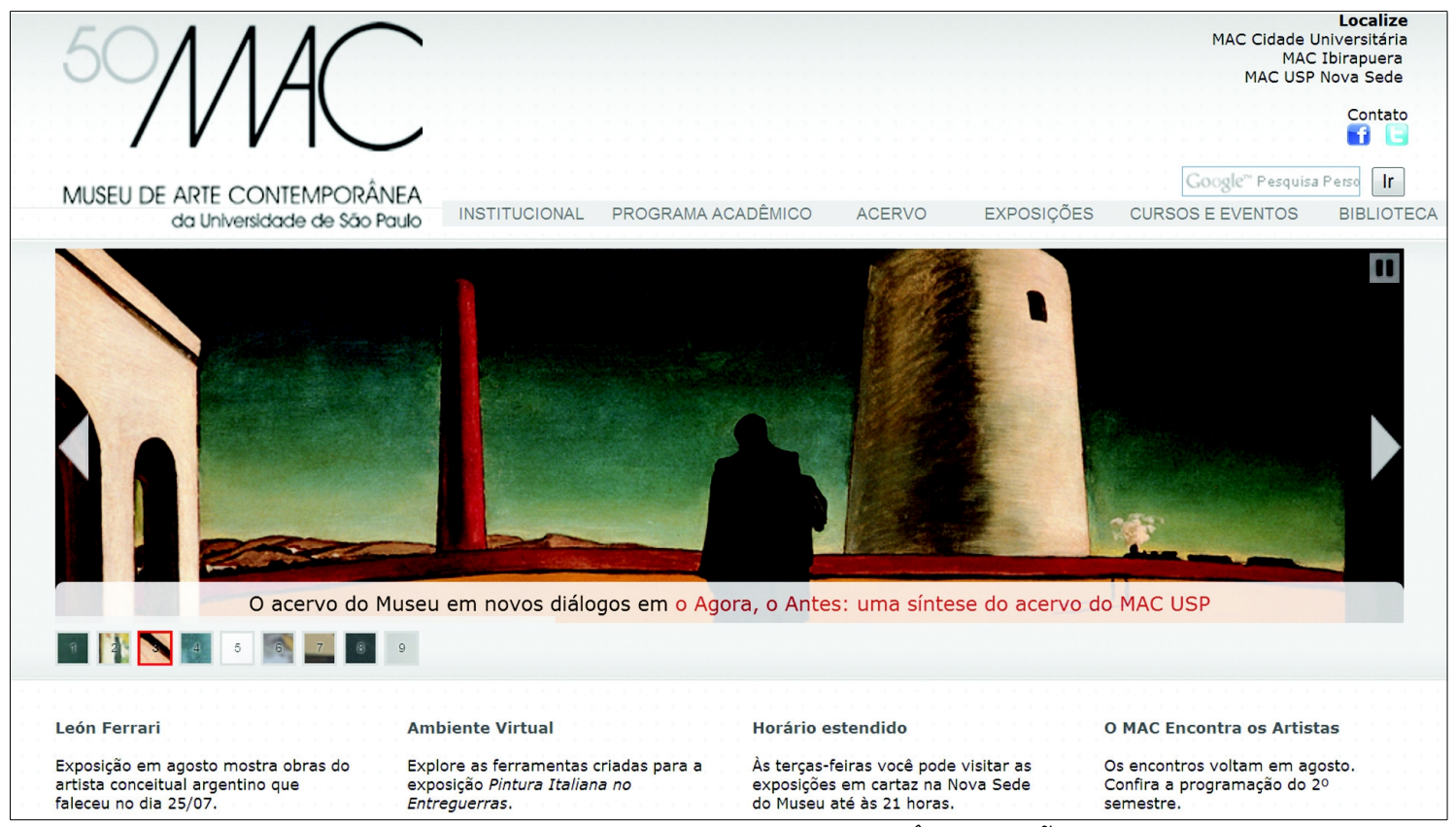

[imagem 05] Site do MUSEU DE ARTE CONTEMPORÂNEA DE SÃO PAULO.

Fonte: $\langle\underline{w w w . m a c . u s p . b r}\rangle$. Acesso em jul/2013. 


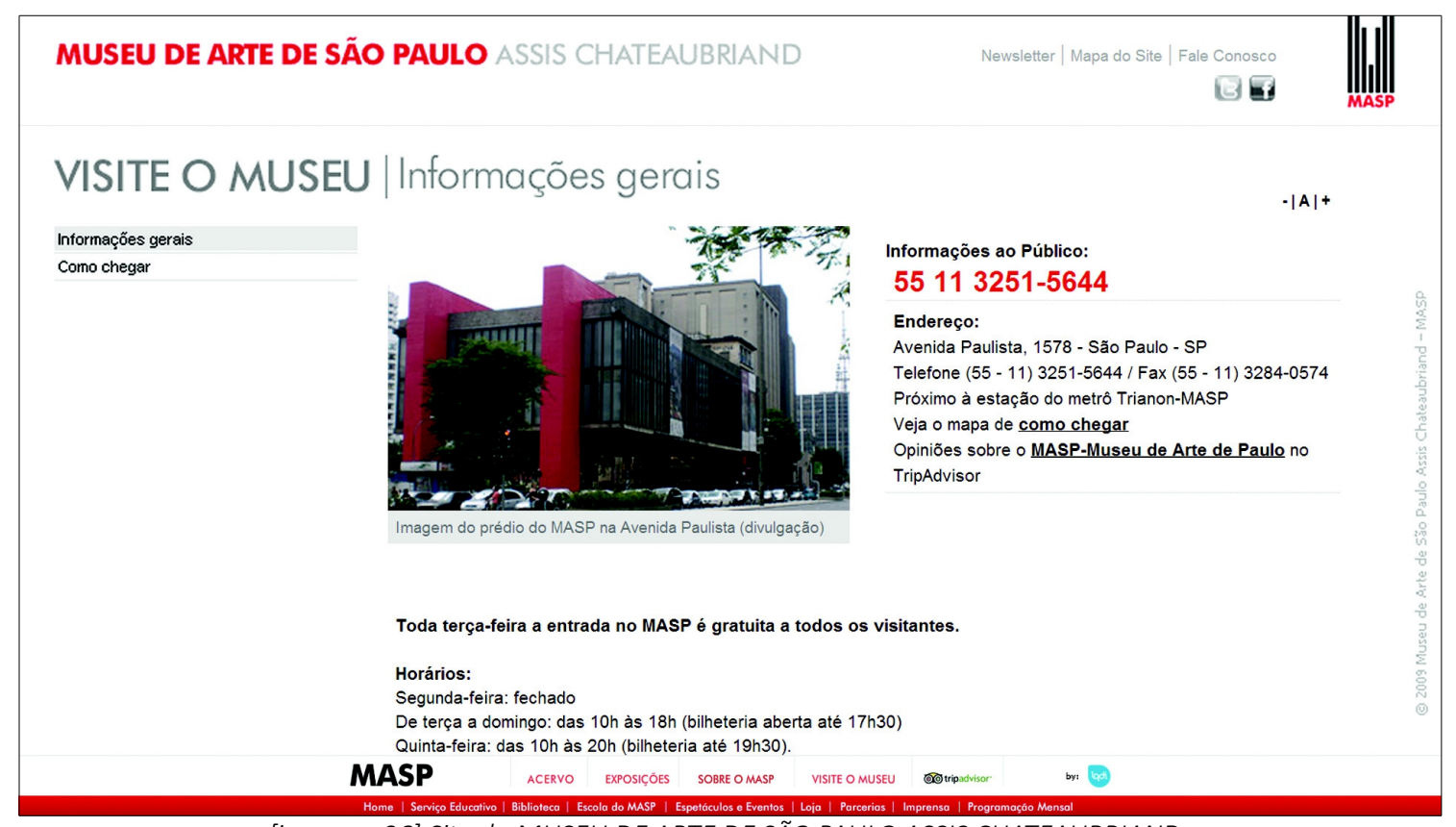

[imagem 06] Site do MUSEU DE ARTE DE SÃO PAULO ASSIS CHATEAUBRIAND.

Fonte: <www.masp.art.br $>$. Acesso em jul/2013.

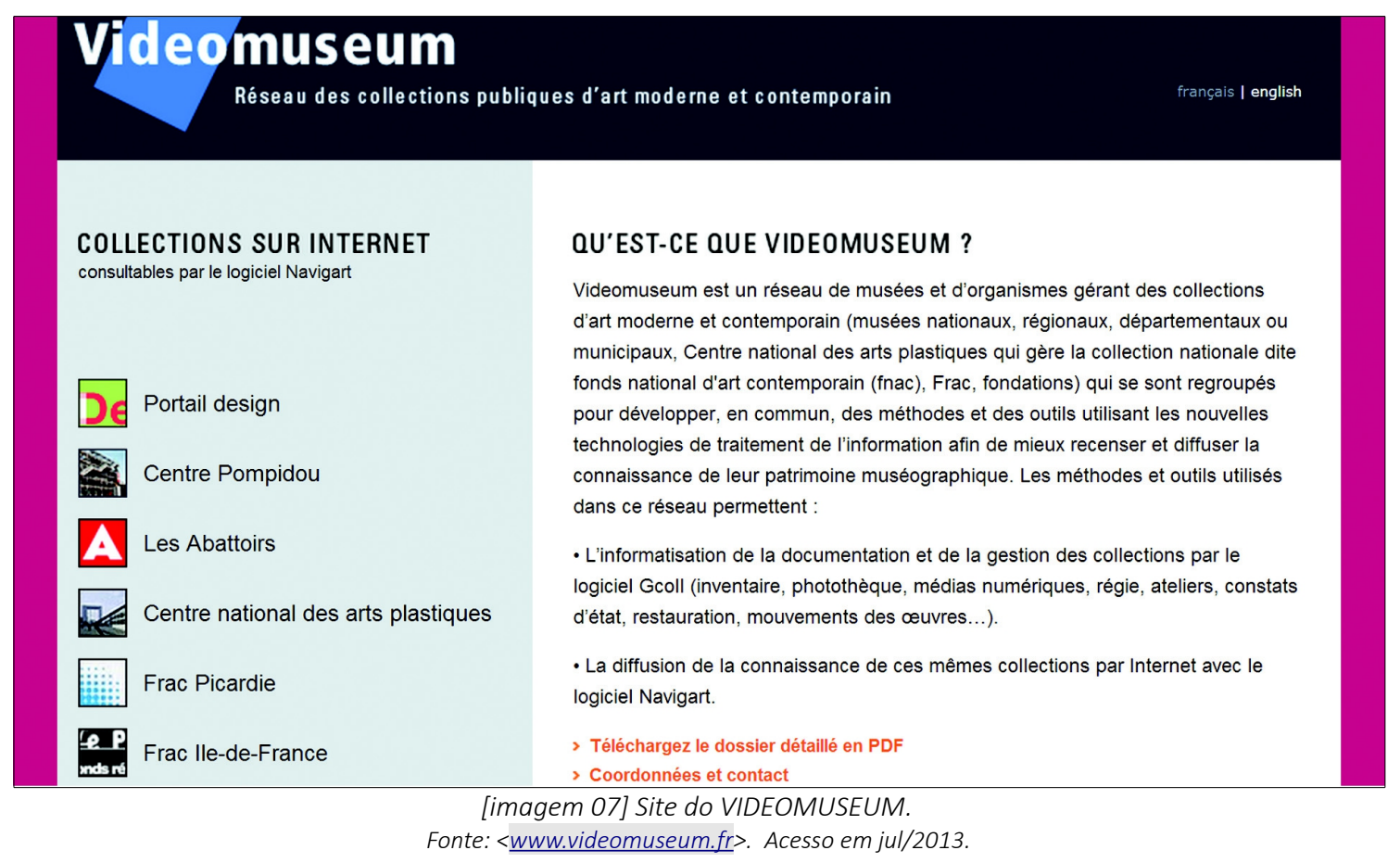




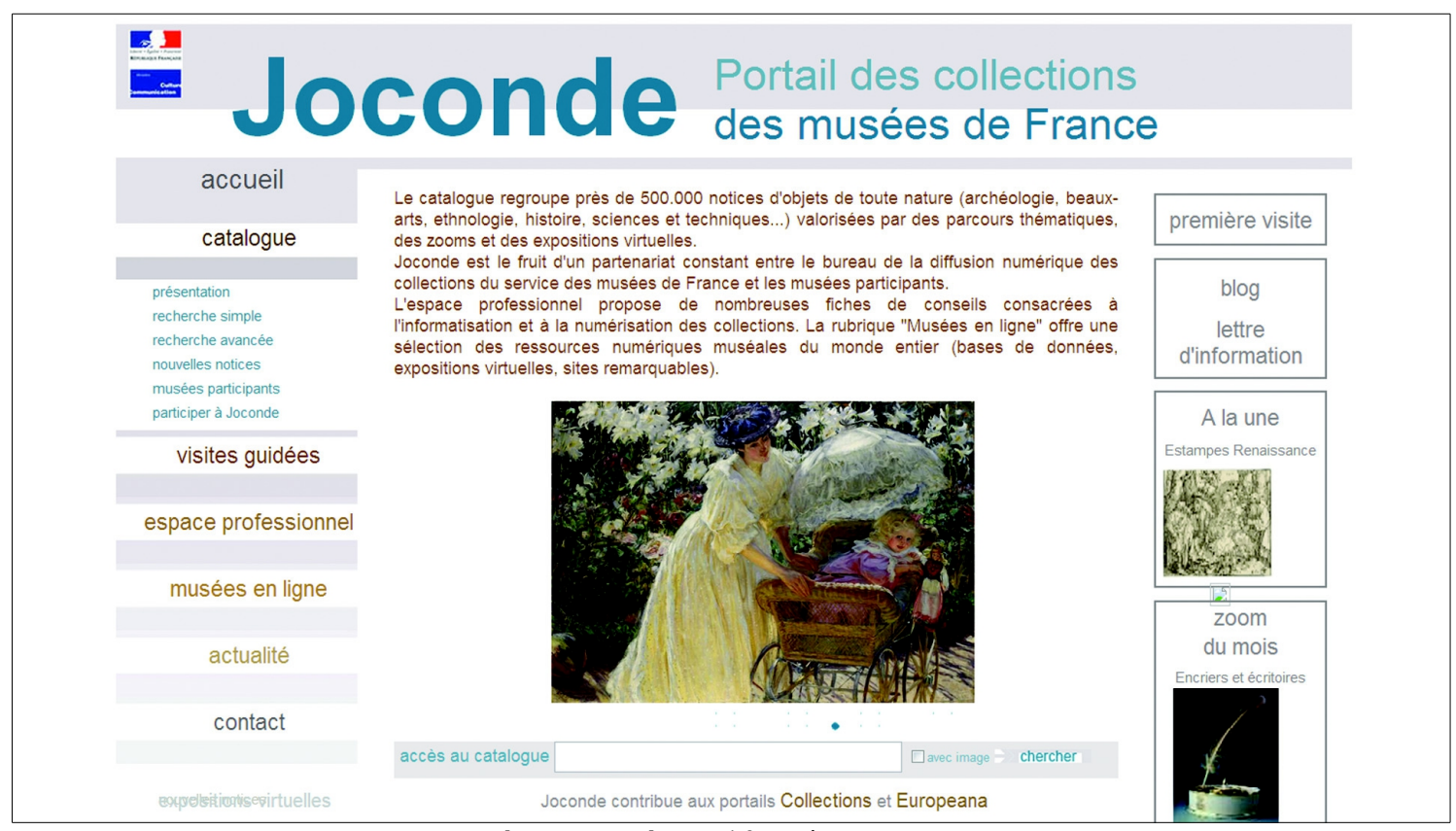

[imagem 08] Portal francês JOCONDE.

Fonte: <www.culture.gouv.fr/documentation/joconde $>$. Acesso em jun/2013.

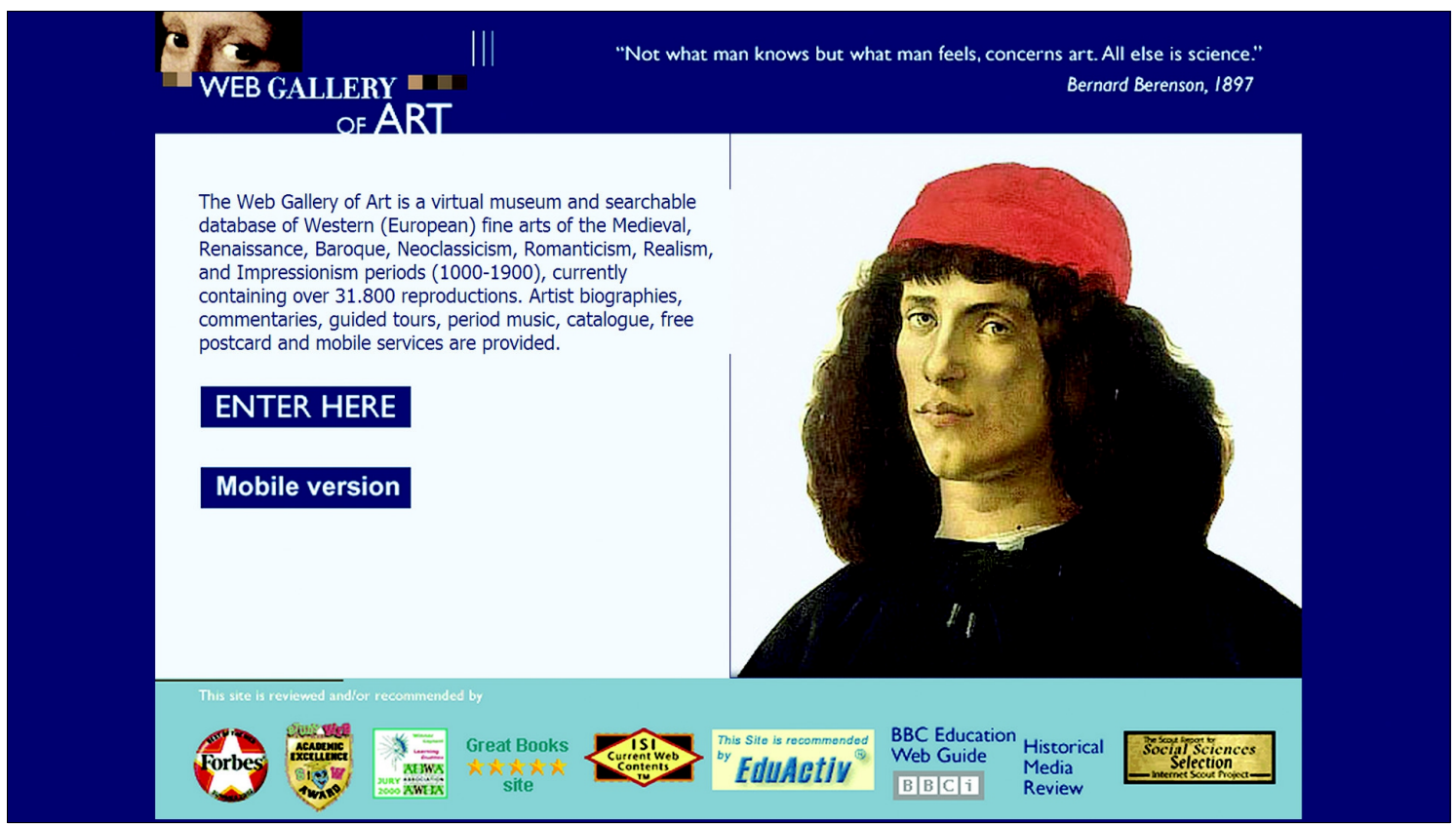

[imagem 09] Página da WEB GALLERY OF ARTE.

Fonte: <www.wga.hu>. Acesso em jun/2013. 


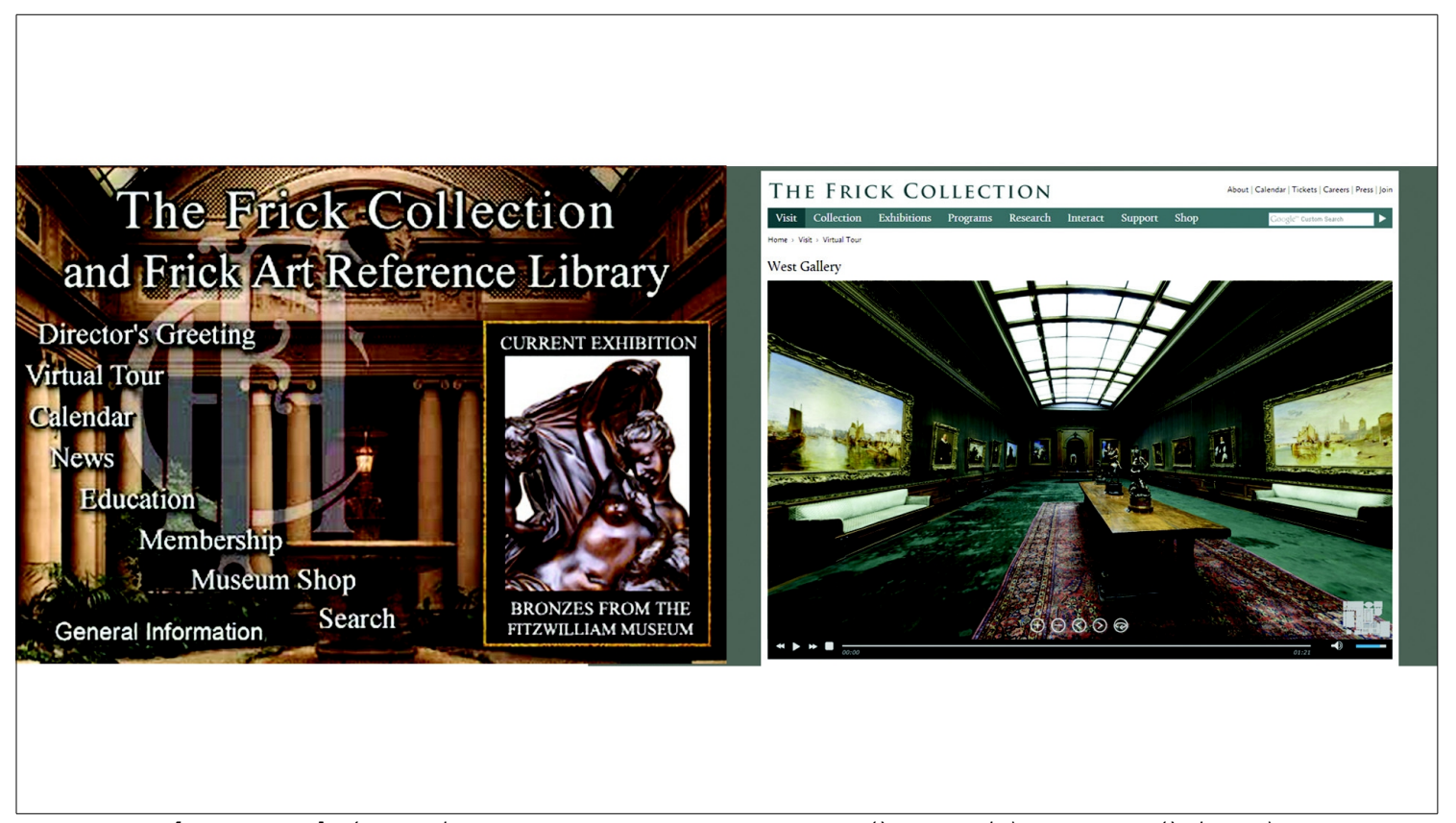

[imagem 10] Páginas da FRICK ART COLLECTION em 1998 (à esquerda) e em 2013 (à direita). Fonte: $\langle w w w$.frick.org $>$. Acesso em jun/2013.

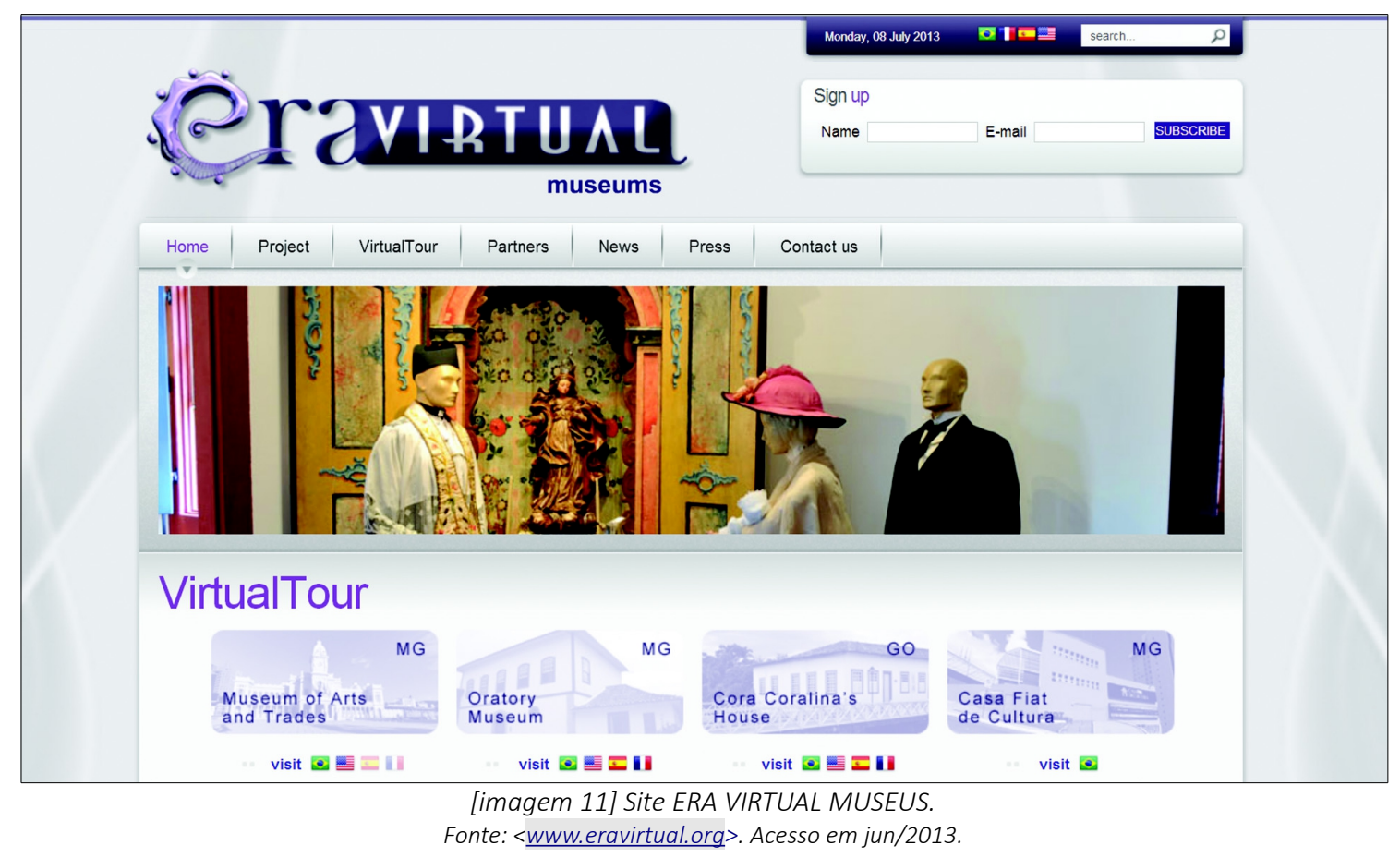




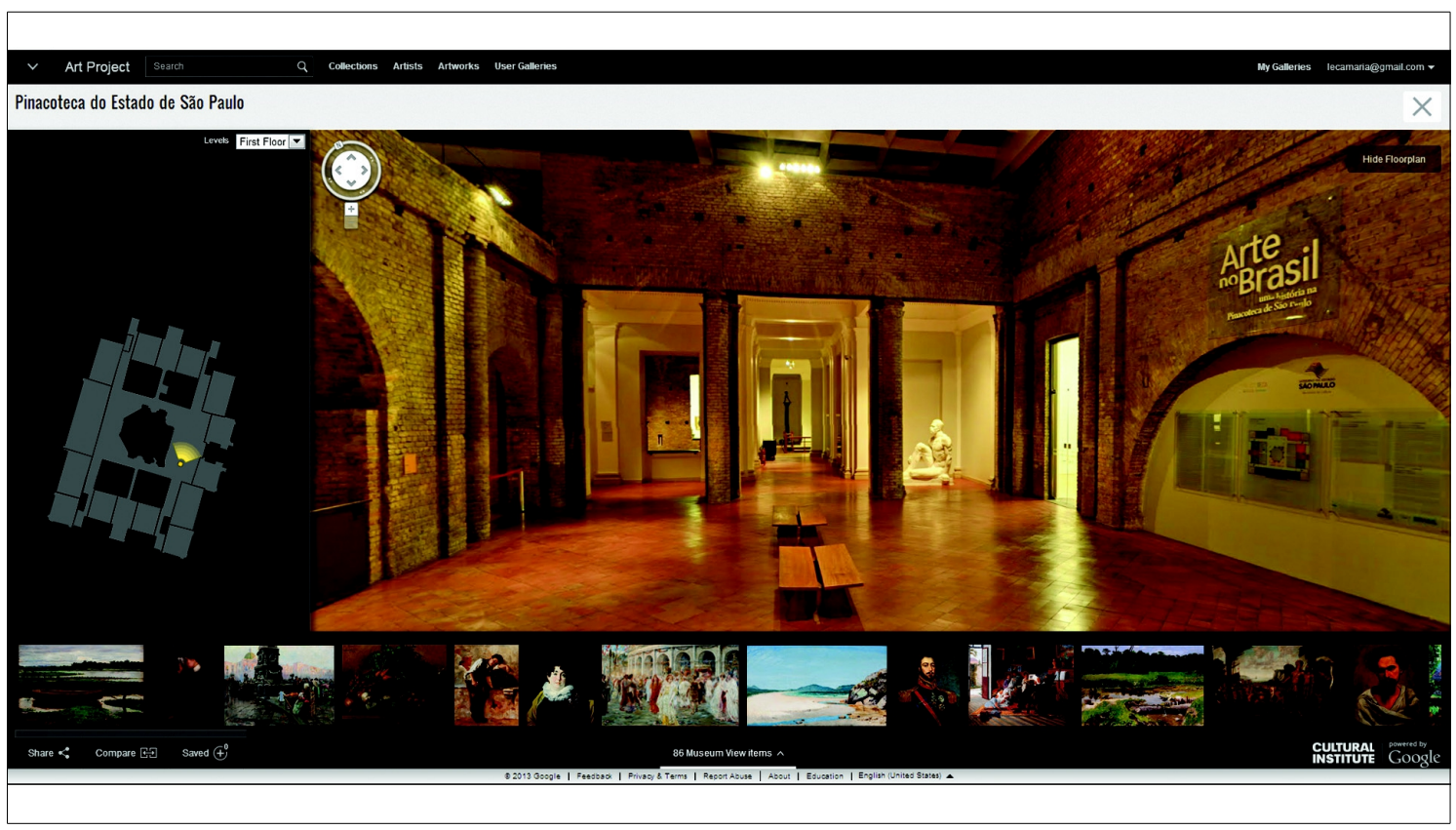

[imagem 12] Página da Pinacoteca do Estado de São Paulo no GOOGLE ART PROJECT.

Fonte: $\langle w w w$.googleartproject.com/collection/pinacoteca-do-estado-de-sao-paulo $\rangle$. Acesso em jul/2013. 


\section{I.3 O SITE DO MUSEU COMO REPOSITÓRIO DE OBRAS PARA A WEB}

A internet rompe a antiga característica isolacionista dos museus, substituída pela conexão de distintos museus entre si e ao usuário final, facilitando o acesso à informação ${ }^{35}$. Ainda assim, eram percebidos novos desafios para a utilização do espaço da internet pelas instituições artísticas. Já se sabia que o website não substituiria o prédio físico do museu, no entanto, o maior desafio era transformar o museu da rede em um lugar para situações que só poderiam ser vividas ali e não um lugar de transposição dos acontecimentos da sede real de exposições.

Esta ideia é absorvida num segundo momento do uso da internet pelos museus, na qual se observa sua preocupação principal com um novo tipo de arte sendo criado, a arte imaterial. O artista e teórico britânico Roy Ascott fala dessa fase que seria chamada de 'Museum of the Second Kind', em português, 'Museu do Segundo Grau':

"Há uma arte destinada para o que poderíamos chamar de Museu do Segundo Grau, que não é originada em pigmento, tela, ou aço, mas que é composta de pixeis desde de sua criação, desde o início digitalmente destinada para a tela do computador, que desliza facilmente na Rede para o consumo mundial instantâneo. Esteticamente é pouco diferente da pintura ou do desenho, no sentido tradicional. A imagem é processada, formas são compostas, um trabalho de finalidade estética é criado. Você pode navegar por ele, mas é basicamente um mundo fechado. Em ambos os casos, a Rede continua a ser um sistema de entrega, uma fonte de arquivo, um catálogo de participações. Ele não desafia as artes plásticas tradicionais, nem as torna redundante. Ele simplesmente aumenta o repertório de imagens e ideias artísticas, atingindo as partes do globo que outros mecanismos de galeria não podem alcançar "136.

35 (Maxwell L. Anderson, 1999) in: BELLIDO GANT, 2002. p. 233-234.

36 AscoTt, Roy. The Museum of the third Kind. Intercommunication, n.15, 1996. Disponivel em: <www.ntticc.or.jp/pub/ic mag/ic015/ascott/ascott e.html. Acesso em: maio/2013. [tradução livre] 
A atividade que nos chama mais a atenção foi a busca pela utilização da internet para a divulgação de obras e exposições feitas especialmente para a web. A arte feita para a internet, programada em softwares de tecnologia computacional, agora seria exposta nos websites dos museus e não apenas em totens de computadores montados em exposições dentro das galerias. Christiane Paul, em Challenges for a ubiquitous museum, ressalva que para o museu se transformar e acomodar essa nova arte, a net-art, há a necessidade de uma grande troca entre instituições, curadores, artistas, obras e espectadores, com o objetivo de aproveitar as propriedades particulares das novas mídias para ampliar o público da $a^{2 t e^{37}}$. Sobre a nova forma de arte nascente, ela também comenta: "toda mídia emergente explora suas próprias características como um passo importante e necessário para moldar a prática artística" ${ }^{38}$.

No final dos anos 90, entramos no momento da aparição dos sites de realização. Páginas cujo objetivo principal era, não apenas disponibilizar e divulgar obras feitas para a plataforma web, mas também colecioná-las.

Um dos sites mais importantes de coleção de obras de web-art é o Museum of Computer Arts $^{39}$. Criado em 1993 por dois artistas americanos, a página hospeda centenas de artistas e milhares de obras de todo o mundo, e é uma das bases de dados de arte computacional mais respeitadas da internet. Constantemente atualizado, o museu eletrônico conserva diversas categorias de arte e tecnologia, como 3-D, fractais, vídeo e técnicas mistas, entre outras [imagem 13].

No mesmo estilo, foi executado no Brasil em 1995, o Museu Virtual para a Arte Computaciona $^{40}{ }^{4}$, dentro da Universidade de Brasília. O site funcionava para a divulgação e organização de trabalhos de arte feita em programas de computadores e pesquisas da época sobre o assunto. O endereço do site ainda é disponível, no entanto pouquíssimos links continuam ativos [imagem 14].

37 PAUL, Christiane. Challenges for a Ubiquitous Museum. In: From the White Cube to the Black Box and Beyond, 2008, p. 53.

38 Idem, 2008, p. 67. [tradução livre]

39 MOCA - MUSEUM OF COMPUTER ART. Disponivel em: < www.museumofcomputerart.org > Acesso em jun/2013.

40 MUSEU VIRTUAL PARA A ARTE COMPUTACIONAL. Disponivel em: < www.arte.unb.br/museu/museu.htm>. Acesso em jul/20I2. 
Já a Dia Art Foundation ${ }^{41}$, de Nova York, mantém-se desde 1995 até os dias atuais no exercício de suas atividades de patrocínio de artistas convidados para a criação de projetos exclusivamente para a internet [imagem 15]. Todas as obras realizadas pelos artistas patrocinados, desde o começo do projeto, estão disponíveis para acesso pelo site, cumprindo uma das mais difíceis funções museológicas que é justamente a preservação da arte tecnológica.

O portal E-space ${ }^{42}$ foi iniciado em 1998 pelo Museu de Arte Moderna de San Francisco ${ }^{43}$, um dos primeiros a adquirir a arte computacional para sua coleção e ainda patrocinar artistas na criação de obras para seu portal web [imagem 16]. Apesar de a página estar fora do ar atualmente, o Museu de Arte Moderna de San Francisco continua com suas pesquisas e com o desenvolvimento nas novas práticas artísticas e mantém um acervo de arte eletrônica disponível em seu site.

Coleção e preservação da net-art é uma das grandes preocupações dos museus atualmente. A arte nascida da tecnologia passa a ser a mais efêmera de todas. Desde a aceitação da videoarte no museu, essas obras vindas das novas mídias encontraram seu espaço para exibição, mas não para coleção. Qual a certeza de que as obras feitas para web estarão acessíveis no futuro? Ou mesmo as tecnologias por elas requisitadas?

Essas questões nos trazem a outras iniciativas importantes, como o ZKM Media Museum $^{44}$, parte do Center for Art and Media Karlsuhe, criado na Alemanha em 1997, com o objetivo de preservar não apenas as obras realizadas com as chamadas novas mídias, como também a mídia em si e os suportes necessários à sua manutenção [imagem 17]. Ou o New Art Trust, um consórcio que reúne especialistas de três grandes centros: MOMA - Museu de Arte Moderna de Nova York ${ }^{45}$, SFMOMA -

4I DIA CENTER FOR THE ARTS. Disponivel em: <www.diacenter.org > Acesso em jul/20II.

42 E.SPACE. Disponibilizado em: <www.sfmoma.org/espace/espace overview.html>. Fora do ar. Acessado pelo Wayback Machine: <www.archive.org>.

43 SFMOMA - San Francisco Museum of Modern Art. Disponivel em: < www.sfmoma.org > Acesso em jul/2012.

44 ZKM MEDIA MUSEUM. Disponibilizado em: <http://onl.zkm.de/zkm/e/institute/medienmuseum>. Acesso em jul/20I2.

45 MUSEUM OF MODERN ART NEW YORK. Disponível em: <www.moma.org >. Acesso em jul/2012. 
Museu de Arte Moderna de San Francisco e a Tate Gallery ${ }^{46}$ de Londres, em parceria dedicada à intensa investigação sobre as necessidades especiais da arte das novas mídias. O objetivo do grupo é atender a necessidade de um acordo entre os museus e colecionadores de todo o mundo sobre a apresentação e preservação de obras de arte com tecnologias avançadas ${ }^{47}$.

O trabalho desenvolvido pelos museus, acionando suas atenções às obras concebidas diretamente para a internet, surge na tentativa de resolver - ou ao menos expandir - algumas das principais preocupações das instituições naquele momento: Como manter a página do museu interessante para o visitante que também irá ao museu físico, além daquele que apenas o acessará desde sua casa? Como atrair o espectador para a web-art se ele experimentará apenas uma das configurações possíveis daquela obra e não a obra completa (já que na arte interativa cada acesso resultaria uma obra diferente)?.

Para Paul, a experiência única com a obra interativa na rede não se trata de uma tentativa de introduzir mais ou menos valor artístico na obra, mas simplesmente uma realidade da prática artística contemporânea ${ }^{48}$. Ascott afirma que esse é o momento no qual o espectador passa a ser ativo na criação da arte e seus significados:

"Na Internet, ver é possuir! O que quer que chegue à sua interface particular, não importa de onde na web, quer se trate de imagem, texto ou frase de efeito, é de sua propriedade. Mais significativamente, é seu para transformar. Transformação, particularmente nas mãos do espectador, é o principal determinante da funcionalidade do museu." 49

Nesse momento o museu virtual começa a deixar de ser um reflexo do museu real e passa a ter vida própria. Não está mais satisfeito com apenas exibir e informar, mas passa também a desafiar o novo público para a ação e a descoberta ${ }^{50}$.

46 TATE MODERN MUSEUM. Disponivel em: <www.tate.org.uk>. Acesso em jul/20II.

47 Maiores informações sobre as atividades do grupo NEW ART TRUST podem ser encontradas em seu perfil no site MUSEUMS AND THE WEB: $<$ www.museumsandtheweb.com/tags/newarttrust $>$. Acesso em jul/2013.

48 PAUL, 2008, p. 71.

49 ASCOTT, 1996. [tradução livre]

50 BATTR0, Antonio M. From Mauraux's imaginary museum to the virtual museum. In: Parry, Ross (ed.) Museums in a age digital. USA: Routledge, 2010 , p. 146. 


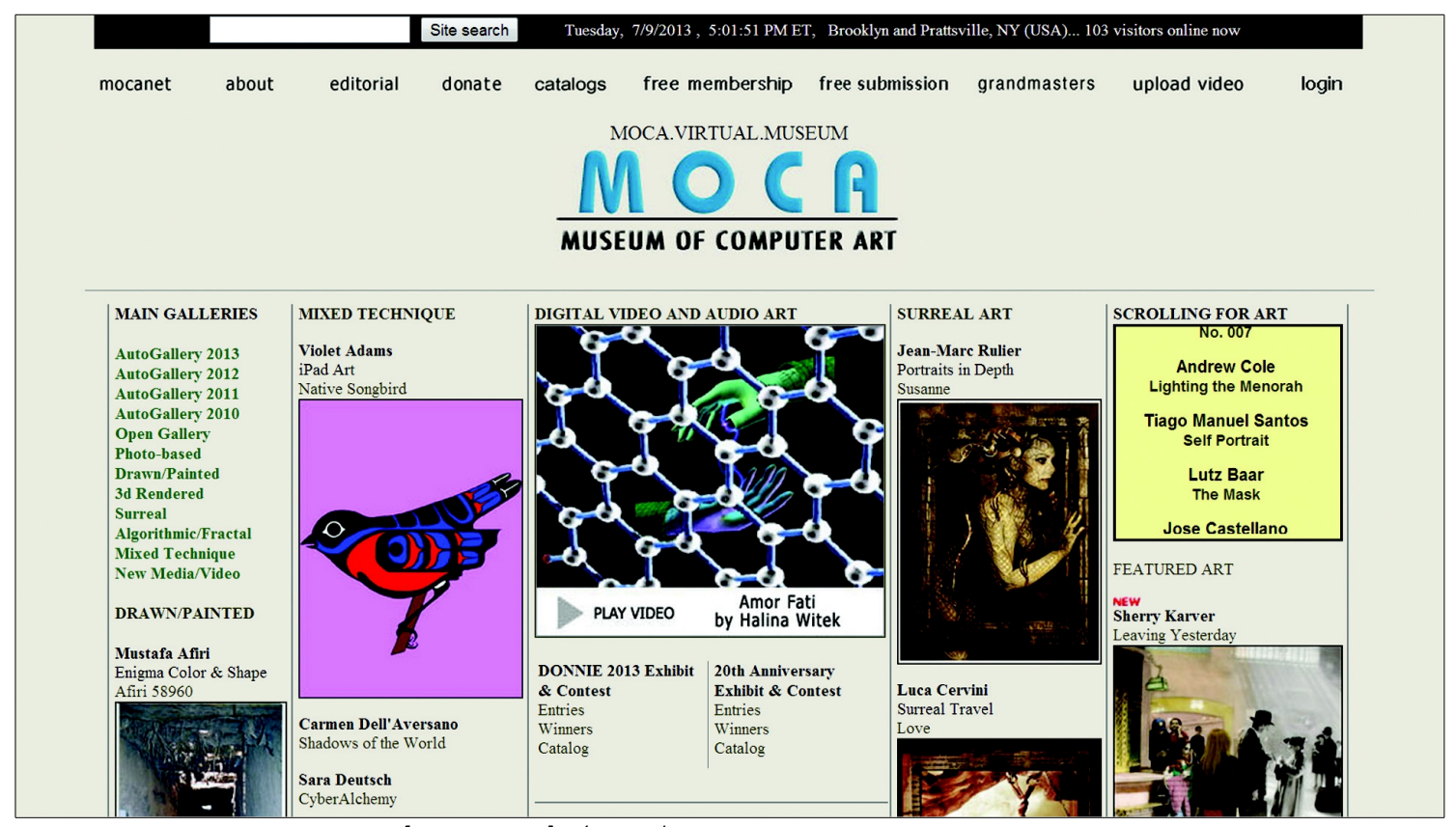

[imagem 13] Página do MUSEUM OF COMPUTER ART.

Fonte: <www. museumofcomputerart.org $>$. Acesso em jul/2013.

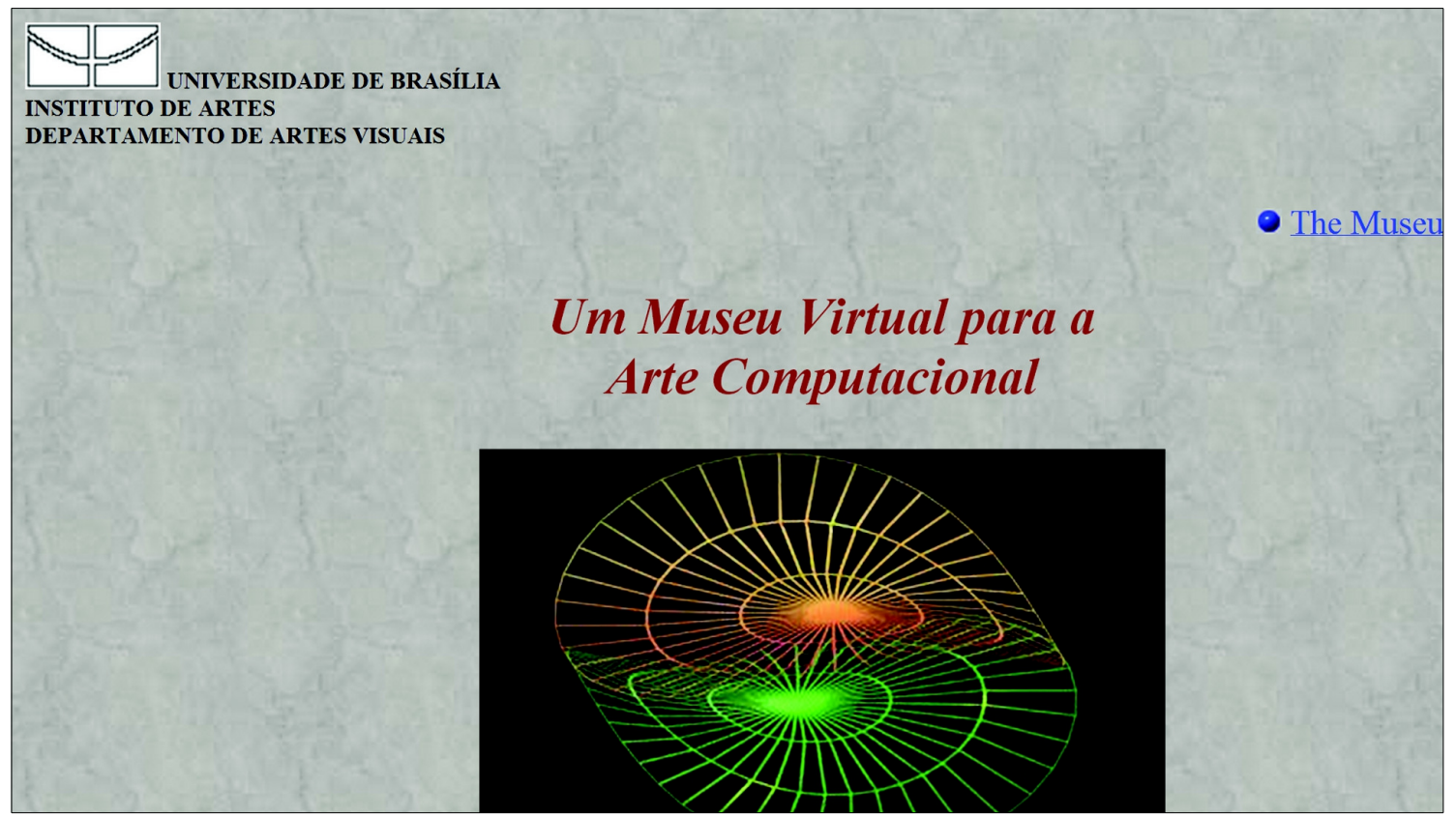

[imagem 14] Site do MUSEU VIRTUAL PARA A ARTE COMPUTACIONAL. Fonte: <www.arte.unb.br/museu/museu.htm $>$. Acesso em jul/2013. 


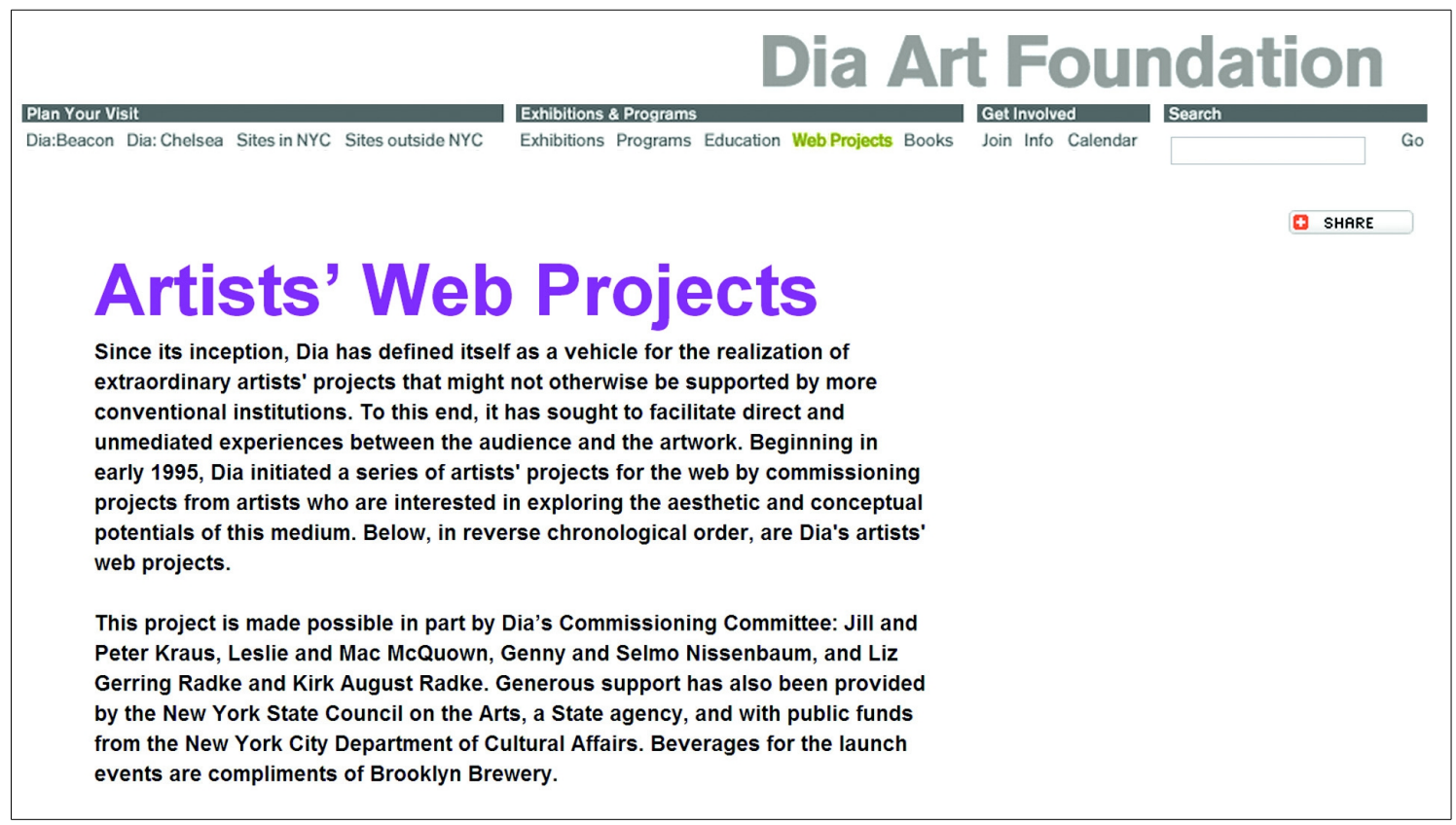

\section{Artists' Web Projects}

Since its inception, Dia has defined itself as a vehicle for the realization of extraordinary artists' projects that might not otherwise be supported by more conventional institutions. To this end, it has sought to facilitate direct and the web by commissioning projects from artists who are interested in exploring the aesthetic and conceptual potentials of this medium. Below, in reverse chronological order, are Dia's artists' brojects. Peter Kraus, Leslie and Mac McQuown, Genny and Selmo Nissenbaum, and Liz the New York City Department of Cultural Affairs. Beverages for the launch [imagem 15] Site do DIA CENTER FOR THE ARTS

Fonte: <www.diacenter.orq $>$. Acesso em jul/2013.

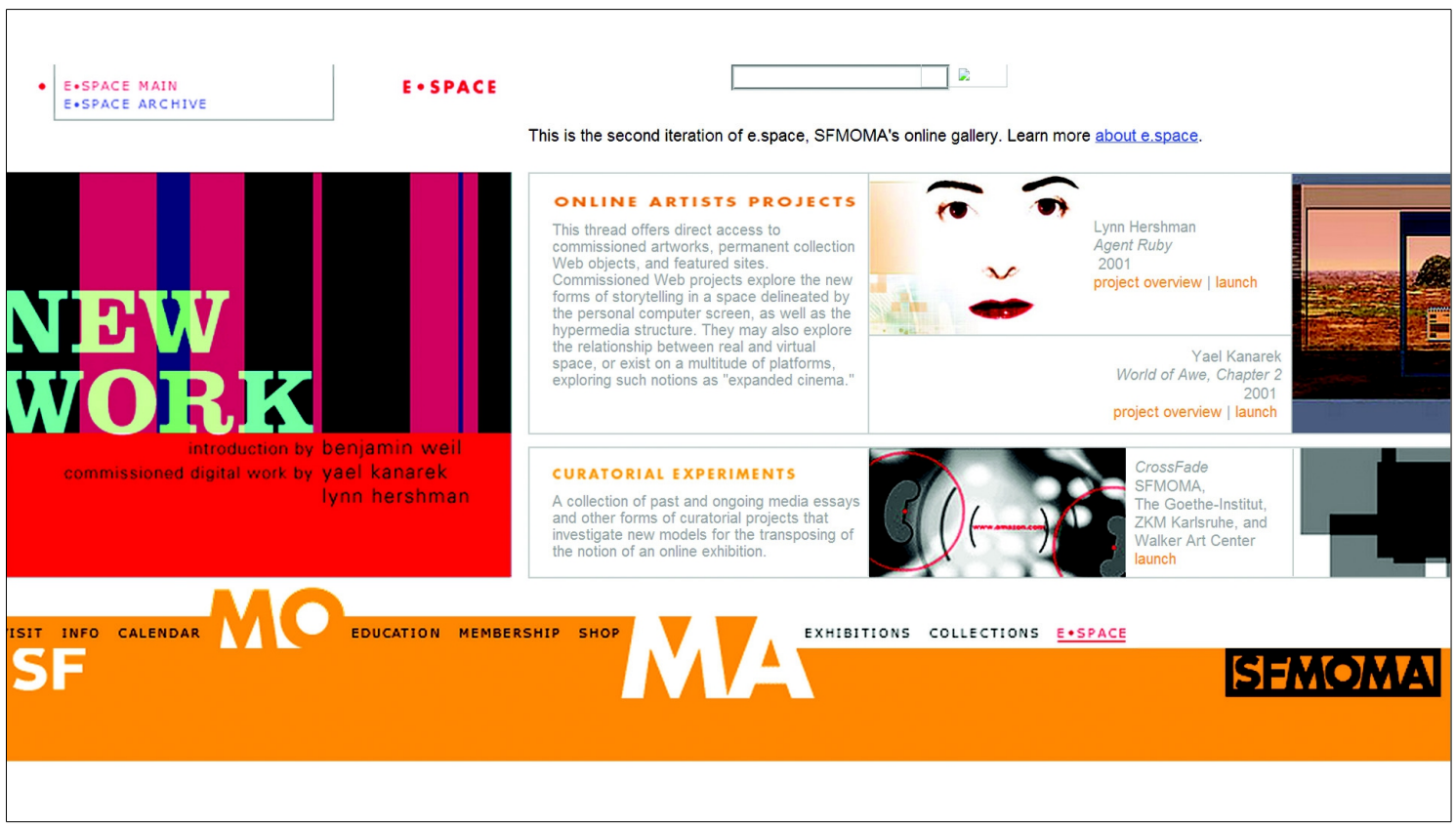

[imagem 16] Site E.SPACE.

Fonte: <www.sfmoma.org/espace/espace overview.html>. Fora do ar. 


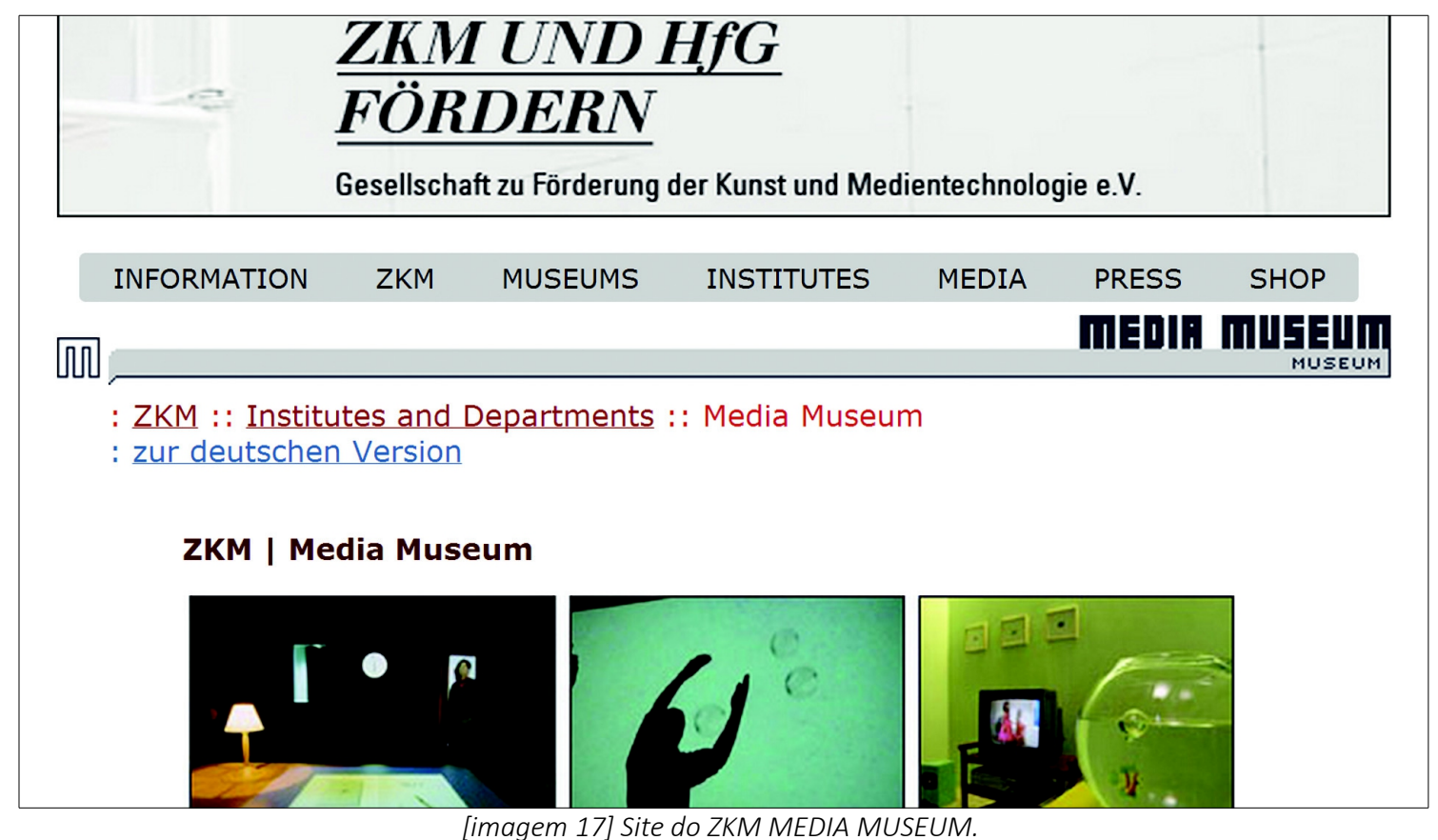

Fonte: $<$ http://on1.zkm.de/zkm/e/institute/medienmuseum $>$. Acesso em jul/2013. 


\section{I.4 OS MUSEUS VIRTUAIS E AS EXPOSIÇÕES DIGITAIS}

Seguindo a linha dos passeios virtuais e entendendo as possibilidades únicas de difusão do patrimônio cultural através dos meios digitais e da rede de computadores, centros e grupos de pesquisa passaram a desenvolver espaços para coleções e exposições que somente existiriam na internet. Esses projetos, executados inteiramente na web desde sua concepção à sua concretização, assumiram o título de 'verdadeiros museus virtuais'.

Um dos primeiros exemplos de museu criado apenas na internet foi o Museo Virtual de Artes $^{51}$. O site uruguaio lançado em 1997 apresenta obras reais digitalizadas para formar uma coleção que não existe em nenhum museu físico. A ideia é disponibilizar à população o acesso às peças que não se encontram em exibição em museus e galerias, por estarem em coleções particulares ou até mesmo desaparecidas. O site é divido em MUVA I, feito em 1997, e MUVA II, projetado dez anos depois, em 2007. Os dois contam com passeios imersivos interativos em prédios 3-D idealizados especificamente para a instituição virtual [imagem 18].

Um projeto mais recente, que também aproveita a ideia da arquitetura do espaço virtual como parte crucial do ambiente museográfico na web é o Adobe Museum of Digital Media ${ }^{52}$, de 2010. Atualmente, grandes centros artísticos tem abraçado a ideia de projetos arquitetônicos icônicos e imponentes e contratado profissionais estrelados para a execução de seus prédios físicos. Também a Adobe escolheu o famoso arquiteto Filippo Innocenti (associado da arquiteta-celebridade Zaha Hadid), para o design de seu espaço virtual de exposições temporárias de arte digital. Innocenti é reconhecido por sua pesquisa envolvendo design digital inspirado na biologia e sua aplicação na arquitetura e engenharia ${ }^{53}$. Ao assistir um tour virtual entendemos que o projeto, sem portas de entrada ou saída, ocuparia $57.608 \mathrm{~m}^{2}$ se

51 MUVA - MUSEO VIRTUAL DE ARTES. Disponivel em: $<$ http://muva.elpais.com.uy >. Acesso em maio/2013.

52 ADOBE MUSEUM OF DIGITAL MEDIA. Diponivel em: <www.adobemuseum.com>. Acesso em maio/2013.

53 Mais informações na homepage do arquiteto: FILIPPO INNOCENTI: <www.filippoinnocenticom>. Acesso em jul/2013. 
fosse realmente construído, e teria 50 andares de altura. O museu se apresenta como "um lugar para refletir sobre a importância e o impacto da mídia digital em nossas vidas" [imagem 19].

Mais um museu que aparece nos últimos anos para abrigar na internet uma forma de arte que só existiria através dessa tecnologia é o Streaming Museum ${ }^{54}$. O museu apresenta exposições via transmissão online, de temática contemporânea às artes plásticas internacionais, para uma audiência global através da Internet, e mantém uma rede em expansão de telas grandes em todo o mundo. É produzido e transmitido de Nova York e inaugurou suas exibições em 2008, exatamente ao mesmo tempo em telas públicas de sete continentes: Joanesburgo (África do Sul), Seul (Coreia do Sul), Melbourne (Austrália), Londres (Inglaterra), Dallas (Estados Unidos), Montevidéu (Uruguai) e na base argentina da Antártida. Desde então, as transmissões do Streaming Museum já foram vistas ao vivo em pelo menos cinquenta e cinco lugares diferentes do globo. O acervo das exibições é disponível em seu site web [imagem 20].

Ainda não citadas, outras investigações muito interessantes são as que utilizam as tecnologias computacionais para criar museus com coleções que deixaram de existir fisicamente, como réplicas de artefatos e até cidades inteiras de civilizações dizimadas. Nesta posição temos o exemplo do Museum With No Frontiers ${ }^{55}$, que tem como objetivo construir coleções inteiras modeladas em 3D para fins educativos e de preservação do patrimônio cultural. Esse tipo de museu pode criar lugares que jamais poderiam ser visitados de outra maneira [imagem 21].

No entanto, apesar de observarmos exemplos bastante importantes na conservação de nosso patrimônio artístico e cultural na rede, a 'autoridade' de museus com versões apenas na internet ainda é intensamente questionada. O consultor alemão Klaus Müller entende que na sociedade atual, as experiências estão sendo cada vez mais produzidas e moldadas pela mídia, e por isso museus costumaram ser o único lugar no qual se encontra o 'autêntico'. Müller explica que "o público escolheu os museus, em vez das escolas, universidades e da mídia, como as mais confiáveis

54 STREAMING MUSEUM. Disponivel em: < www.streamingmuseum.org $>$. Acesso em maio/2013.

55 MUSEUMS WITH NO FRONTIERS. Disponivel em: <www.discoverislamicart.org > Acesso em jul/20II. 
instituições culturais"”56. Ele indaga que "quando museus se definem como vitrines de objetos materiais que os visitantes podem experimentar no local, o modo de visualização virtual na web parece ser uma distorção desse encontro" ${ }^{57}$. Porém, ainda defende a ideia da utilização do meio digital além da simples reprodução de objetos reais, pois acredita que a virtualidade é uma prática fundamental de exibição, assim como a curadoria e a arquitetura ${ }^{58}$. Müller aponta:

"Virtualidade vem do latim virtus, que tem vários significados, incluindo excelência, força, poder, e (em sua forma plural) superpoderes. A palavra descreve um modo de participação ou potencialidade. Neste sentido, objetos virtuais podem ser vistos como iluminando os potenciais significados da arte e de outros objetos. (...) Assim, a virtualidade deve ser entendida como uma complexa interpretação cultural de objetos que nos obriga a repensar as marcas tangíveis e intangíveis da história de nossa cultura" ${ }^{15}$.

Ainda sim, como veremos no capítulo a seguir, os museus que mais usufruíram dos benefícios trazidos pela comunicação online, foram os grandes museus que já mantinham excelente reputação com suas instituições físicas. Ao trazerem suas marcas e toda sua identidade visual para dentro da rede, de alguma forma, a autoridade também era mantida. As acadêmicas Graham e Cook conferem aos museus artísticos 'selos de aprovação': "museus de arte têm grandes orçamentos de publicidade, um vasto público ouviu falar deles, e eles são o lugar onde as pessoas vão para encontrar arte. (...) Mais importante, eles têm publicações, documentação e coleções - são onde a história da arte é feita" ${ }^{60}$.

56 MÜLLER, Klaus. Museums and virtuality. In: Parry, Ross (ed.) Museums in a age digital. USA: Routledge, 2010, p. 297. [tradução livre]

57 Idem, 2010, p. 296-297. [tradução livre]

58 Idem, 2010, p. 297.

59 Idem, 2010, p. 296. [tradução livre]

60 GRAHAM, Beryl; COOK, Sarah. Rethinking curating - Art after new media. Cambridge: The MIT Press, 2010, p. 190. [tradução livre] 


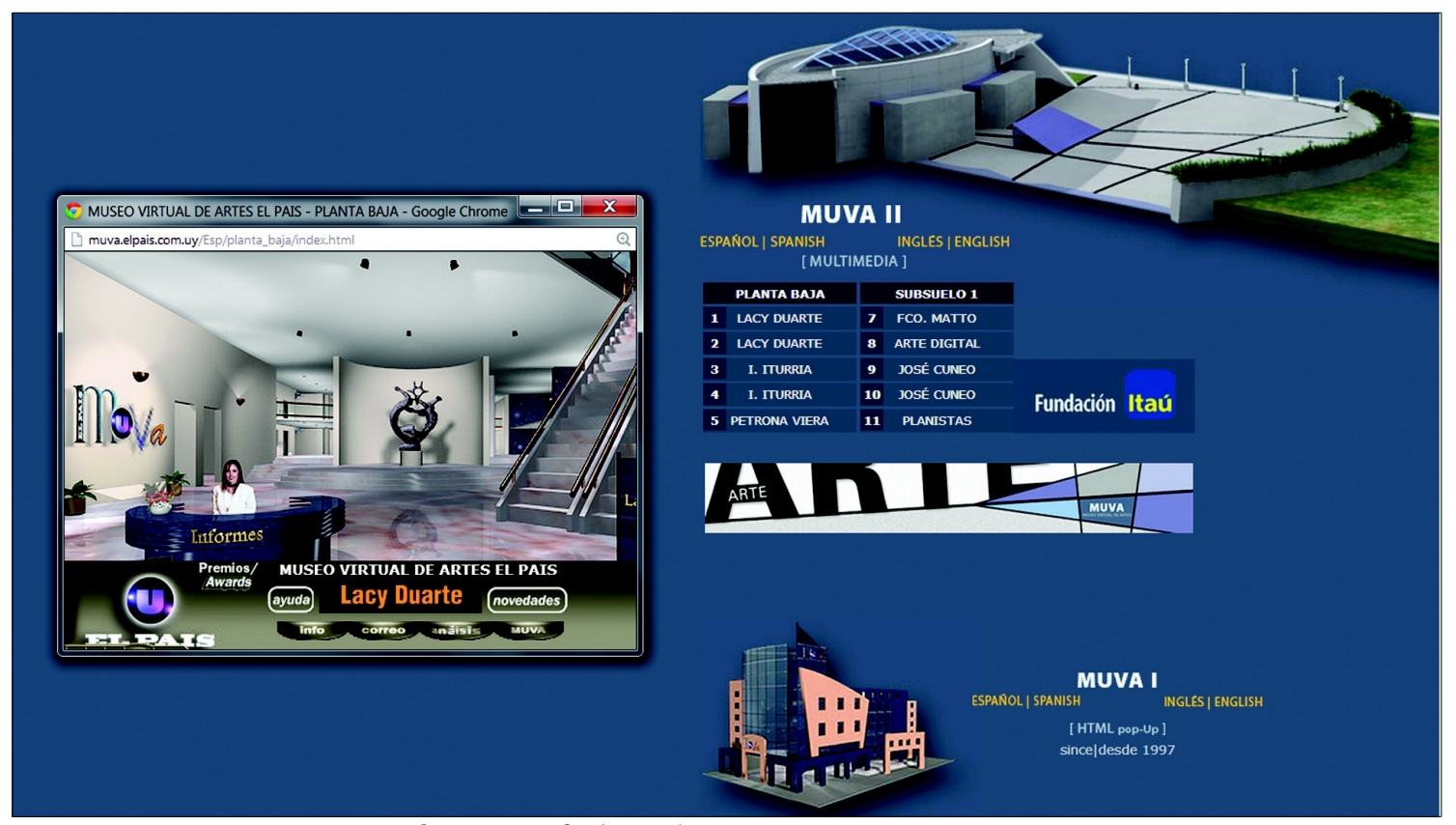

[imagem 18] Página do MUSEO VIRTUAL DE ARTES.

Fonte: <http://muva.elpais.com.uy>. Acesso em maio/2013.

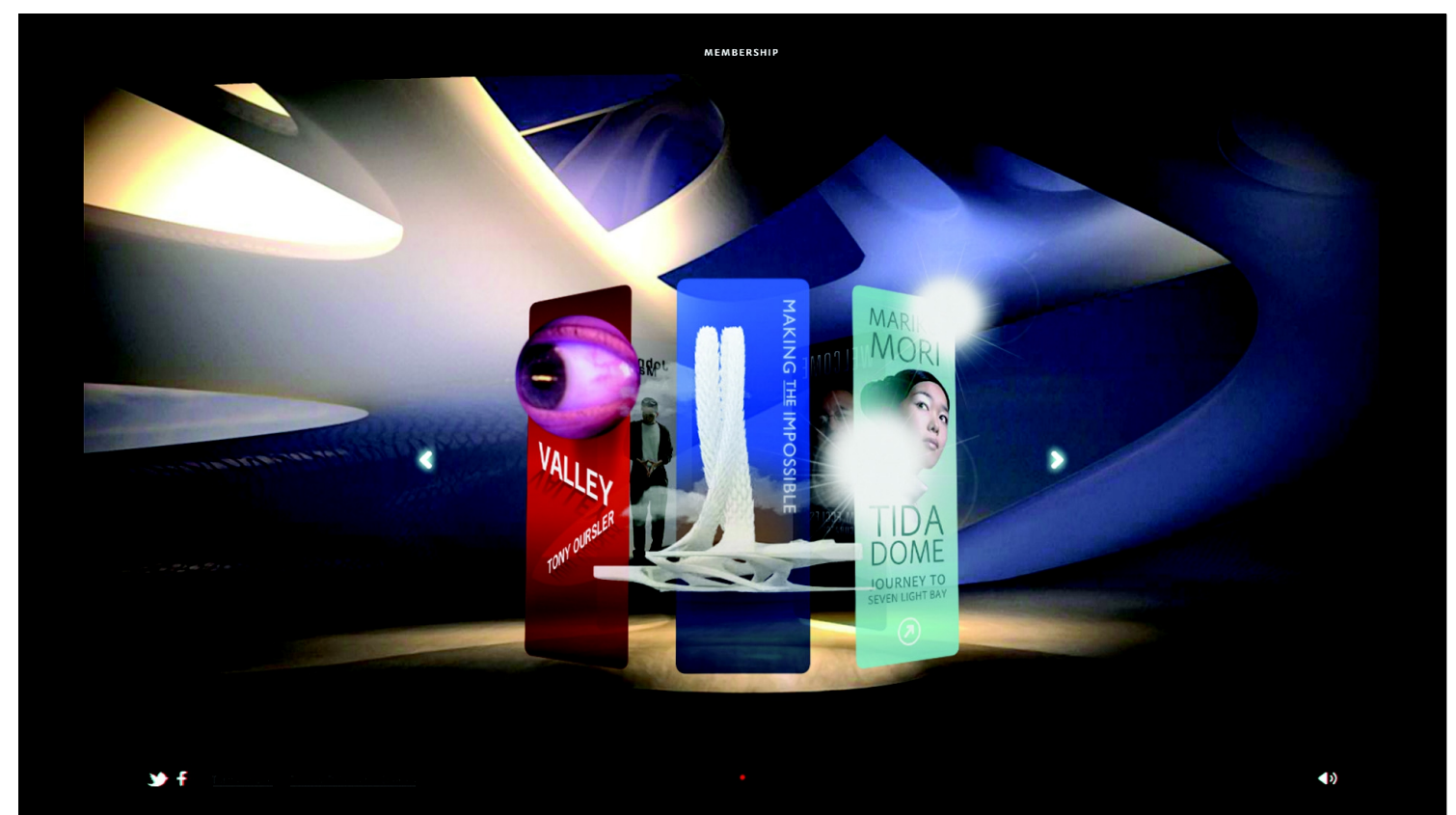

[imagem 19] Site do ADOBE MUSEUM OF DIGITAL MEDIA.

Fonte: $\langle$ www.adobemuseum.com $>$. Acesso em maio/2013. 


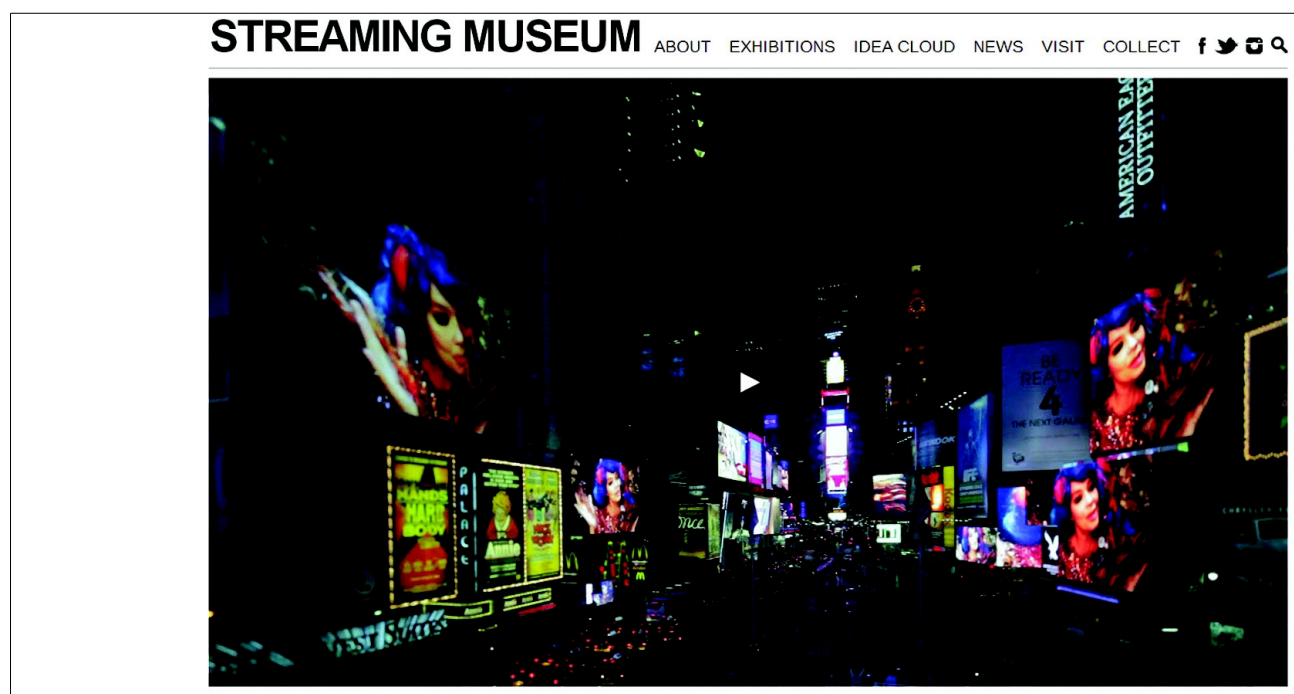

FEATURED

Times Square Arts and Streaming Museum Go Global with Björk's "Mutual Core" to Screens on 7 Continents

[imagem 20] Site do STREAMING MUSEUM.

Fonte: <www.streamingmuseum.org $>$. Acesso em maio/2013.

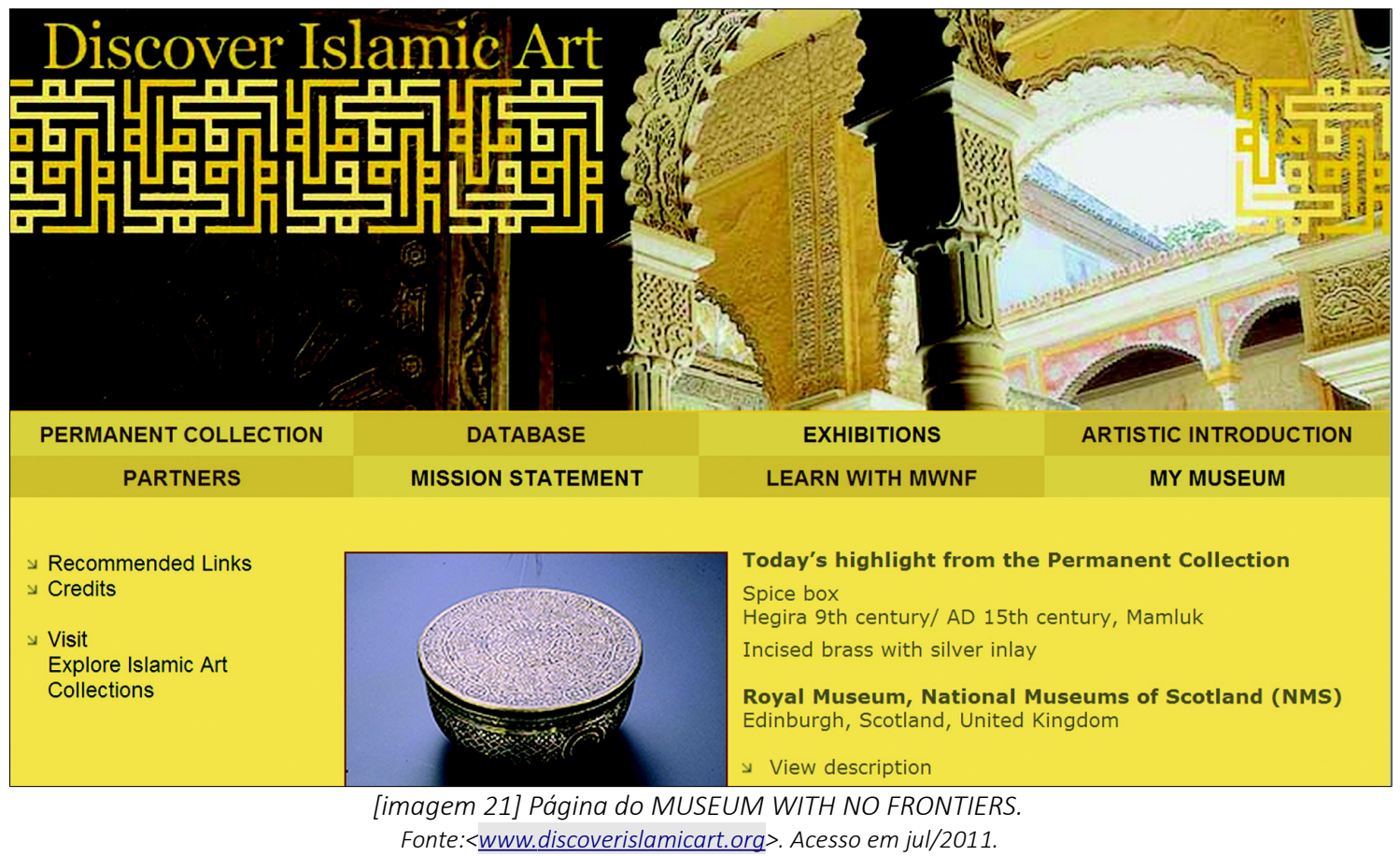


"O próximo meio, seja ele qual for - pode ser a extensão da consciência incluirá a televisão como seu conteúdo, não como seu entorno, e transformará a televisão em uma forma de arte. Um computador como instrumento de pesquisa e comunicação pode aprimorar a restauração/organização obsoleta da biblioteca de massa, recuperar a função enciclopédica do indivíduo e transformar-se em uma linha privada de dados rapidamente atualizados e negociáveis".

[Marshall McLuhan, 1962] 


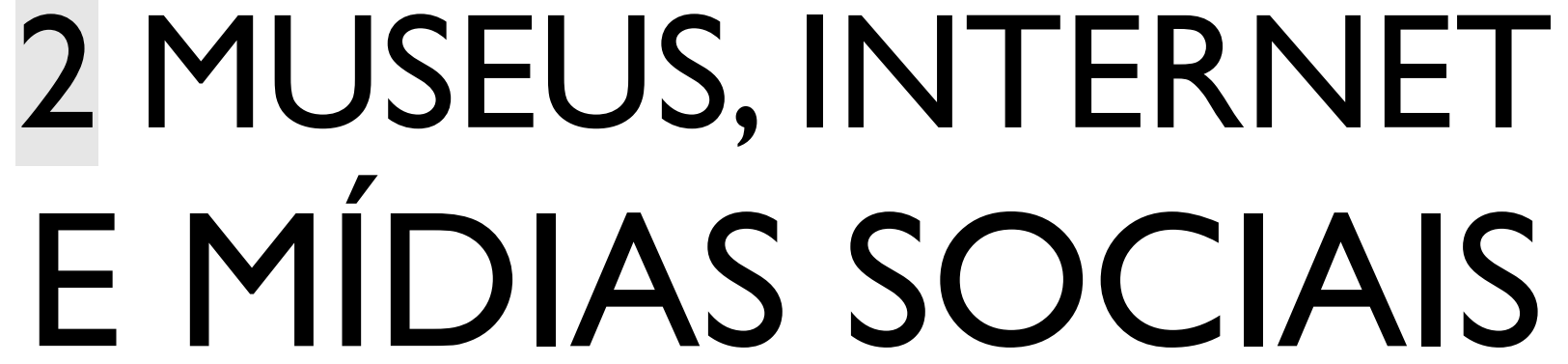

\section{I O MUSEU ON-LINE COMO EXTENSÃO DO MUSEU OFF-LINE}

No começo do século XXI, novas questões continuam surgindo quanto ao aproveitamento do potencial da internet na difusão artístico-cultural. Os museus entendem que devem manter sua realidade física com diversificadas oportunidades e ainda, ser um emissor de informações de grande adaptabilidade às circunstâncias de produção e usufruto da arte em um mundo cada vez mais dependente das redes digitais de comunicação e da telepresença ${ }^{61}$. A maior variável envolvida na equação seria o novo tipo de espectador do museu virtual: o que querem esses novos espectadores que não atuam mais apenas de forma passiva diante ao acesso digital das informações?

Em um terceiro momento de 'descoberta' das possibilidades da internet pelas instituições artísticas e culturais, temos exemplos nos principais museus de arte contemporânea do mundo. Observa-se que primeiro, os museus começam a usar a internet buscando maior projeção social, para descobrirem que a cultura passa a ser um valor social, acessível a todos, e a arte, uma manifestação que pode se instalar na experiência cotidiana ${ }^{62}$. A rede oferece a oportunidade, que para muitos não existia, de usufruir do acervo e das atividades de grandes centros artísticos, mudando definitivamente a forma com que as pessoas lidariam com a informação cultural.

6I BELLIDO GANT, 200I. p. 246.

62 Idem, 2001 , p. 237. 
Os grandes museus tiveram que descobrir como utilizar as possibilidades da programação online para construir experiências que fossem além de uma visita ao museu. Havia a preocupação com a perda da 'aura' e como compensar o nãoencontro físico com a obra. Para Müller "a transformação do domínio físico para o digital tem obscurecido a distinção entre autêntico e virtual: cada vez mais eles se sobrepõem" ${ }^{\prime 63}$. Os programas digitais podem eliminar completamente a dimensão física, mas oferecem novas formas de contextualizar os objetos com camadas interativas de informação ${ }^{64}$. Ele também lembra que o amor das pessoas pela arte e pela cultura foi, historicamente, alimentado por reproduções e aponta:

"Enquanto a singularidade e presença dos artefatos desaparece em sua duplicação, a maioria de suas camadas informacionais permanecer intacta. Educação e compreensão da cultura é baseada em informações e não exclusivamente na experiência enfática da presença do objeto" ${ }^{65}$.

Bandelli identifica que a critica mais comum aos computadores e a internet sempre foi a de isolar as pessoas umas das outras, mas que, contrariando isso, o museu consegue usar a web como uma ferramenta para aumentar o seu alcance e ampliar o espaço social ${ }^{66}$. Ele ainda afirma que "a chave para entender a relação entre um museu virtual e um real é, portanto, compreender ações sociais no espaço e no tempo, e a relevância dos objetos únicos, ou aqueles reprodutíveis, e maneiras de experienciá-los ${ }^{67 \prime \prime}$.

Müller cita uma série de pontos importantes na hora dos museus ampliarem suas atividades para além do ambiente offline e planejarem exposições online interativas:

Espaço - O acesso deve ser possível de qualquer computador do mundo. Exposições on-line não são regionais, elas falam com um público global. A visualização digital deve desafiar e expandir a nossa percepção de obras de arte.

63 MÜLLER, 2010, p. 298. [tradução livre]

64 Idem, 2010, p. 297.

65 Idem, 2010, p. 300. [tradução livre]

66 BANDELLI, 2010, p. 149.

67 Idem, 2010, p. 152. [tradução livre] 
Tempo - Exposições online são definidas pelo tempo que os visitantes precisam utilizá-las. Os visitantes podem entrar e sair quando quiserem e perder a noção da hora. O tempo na web é organizado pelas necessidades individuais do usuário.

Links - Exibições online devem levar a estruturas de múltiplas camadas que combinam informação textual e visual, sons e imagens.

Narrativa - Reproduções digitais só ganham profundidade, quando são apresentadas como parte de uma história maior. Narrativas criam a sensação de espaço que a web precisa.

Interatividade - Exposições online devem encontrar maneiras de fomentar a interatividade e facilitar o acesso. Criando um mercado aberto de abordagem interativa que permite que os visitantes se tornam colaboradores.

Valores de produção - Trabalhar com a informação digitalizada é mais barato, mais rápido e mais flexível. Os baixos custos de produção de exposições online as tornam boas ferramentas para pequenos e grandes museus se redefinir e inovar.

Acessibilidade - Não criar problemas para pessoas com deficiências e aumentar a acessibilidade a recursos museológicos é o principal incentivo dos programas de patrimônio digital. ${ }^{68}$

Os grandes museus aceleraram suas atividades online como uma expansão natural de seus projetos museológicos, durante toda a primeira década do século XXI. Um bom exemplo do desenvolvimento de novas relações com o público através de sua página na internet é o do Museu de Arte Moderna de Nova York ${ }^{69}$. O MOMA-NY possui um site bastante complexo, altamente atualizado e com uma incrível variedade de aplicativos para o usufruto do espectador. Além do conteúdo tradicional informações básicas para visitas físicas e sobre o espaço e sua programação, base de dados com a coleção e as publicações do museu, área para ações educativas direcionadas a diversos públicos; associações de amigos e patrocinadores da instituição e loja virtual - a página do MOMA conta com uma série de atrações interativas de toda a sorte de 'novidades' do mundo virtual.

68 MÜLLER, 2010, p. 30I-302.

69 MUSEUM OF MODERN ART NEW YORK. Disponivel em: < www.moma.org >. Acesso em jul/2012. 
Na opção do menu denominada Explore [imagem 22], o MOMA-NY oferece uma plataforma chamada MOMAmultimedia. Nela encontramos uma atração interativa de visualização 3D das exposições programada em Flash; links para webpages de exposições em cartaz e antigas; tutoriais para professores, jogos interativos sobre arte para crianças e adolescentes; além de trailers de suas mostras de filmes e vídeos promocionais de exposições [imagem 23].

Também podemos observar o site do Museu Guggenheim New York ${ }^{70}$. O endereço principal do grupo Guggenheim nos leva diretamente a página do museu de Nova York. Porém, ela sustenta uma aba superior com links para todos os outros museus da família: Bilbao, Veneza, Abu Dhabi, além de exposições internacionais. Nesta mesma página principal, temos informações para visitação, doações, programação de exposições e eventos, institucional, educacional, assessoria de imprensa, loja virtual, interatividade e coleção online [imagem 24].

Na página relacionada a funções interativas, encontramos as opções: comunidades (com links para as redes sociais de diversos departamentos do Museu Guggenheim); 'para ouvir' (um arquivo de podcasts de 2006 a 2008 e um banco de gravações de áudio feitas pelo museu entre 1952 e 1990); 'para assistir' (com uma série de vídeos sobre os bastidores das montagens de exposições); fórum online (no qual o museu incentiva visitantes a entrar em discussões sobre as artes em geral); blogs (blogs de diversas áreas do museu atualizados constantemente com informações relevantes aos seus campos de estudo); 'para participar' (com atividades, concursos e festivais aos quais o público é convidado a participar); além de e-cards e e-news (nos quais o público pode enviar cartões-postais virtuais ilustrados com obras do museu ou receber notícias da instituição via e-mail) [imagem 25].

No website da Tate Gallery de Londres, outro importante centro de arte contemporânea, temos na página de entrada ligação para os sites de seus quatro espaços físicos: Tate Britain, Tate Modern, Tate Liverpool e Tate St Ives. Além de links para sessões como: exposições, eventos, recomendações, artistas e coleção,

70 GUGGENHEIM MUSEUM. Disponivel em: <www.guggenheim.org > Acesso em jul/2013. 
informações, importantes, blogs e canal de vídeo, doações, aprendizagem, pesquisa, institucional e loja. Todos com mais inúmeras divisões, como por exemplo o menu educativo, que apresenta uma área infantil bastante interativa, a Tate Kids, com dezenas de jogos online, filmes e desenhos animados, sugestões de atividades de artesanato, e a possibilidade das crianças enviarem suas próprias criações para uma galeria virtual [imagem 26].

No mesmo menu educativo também temos opções para jovens e adultos. A Tate Learn, com: recursos online de aprofundamento em exposições específicas, notas de ensino para professores, recursos para exploração de outros nove museus e galerias, um mapa para apresentação de arte para pessoas com deficiências visuais, guia para cursos e workshops, além de comunidades online nas quais jovens podem partilhar suas ideias e trabalhos artísticos [imagem 27].

Como podemos observar, na existência de uma versão offline e de uma versão online do mesmo museu, as duas acabam interligando-se. A presença eletrônica do museu aumenta as possibilidades de interação com a informação cultural dentro dele, fora dele e dentro da própria rede. Junto com a evolução da tecnologia e da internet, também os museus ampliaram sua participação na sociedade. Eles conseguiram alcançar novos espectadores, melhorar a experiência do visitante online e offline, e se tornaram mais relevantes para a integração cultural global. 


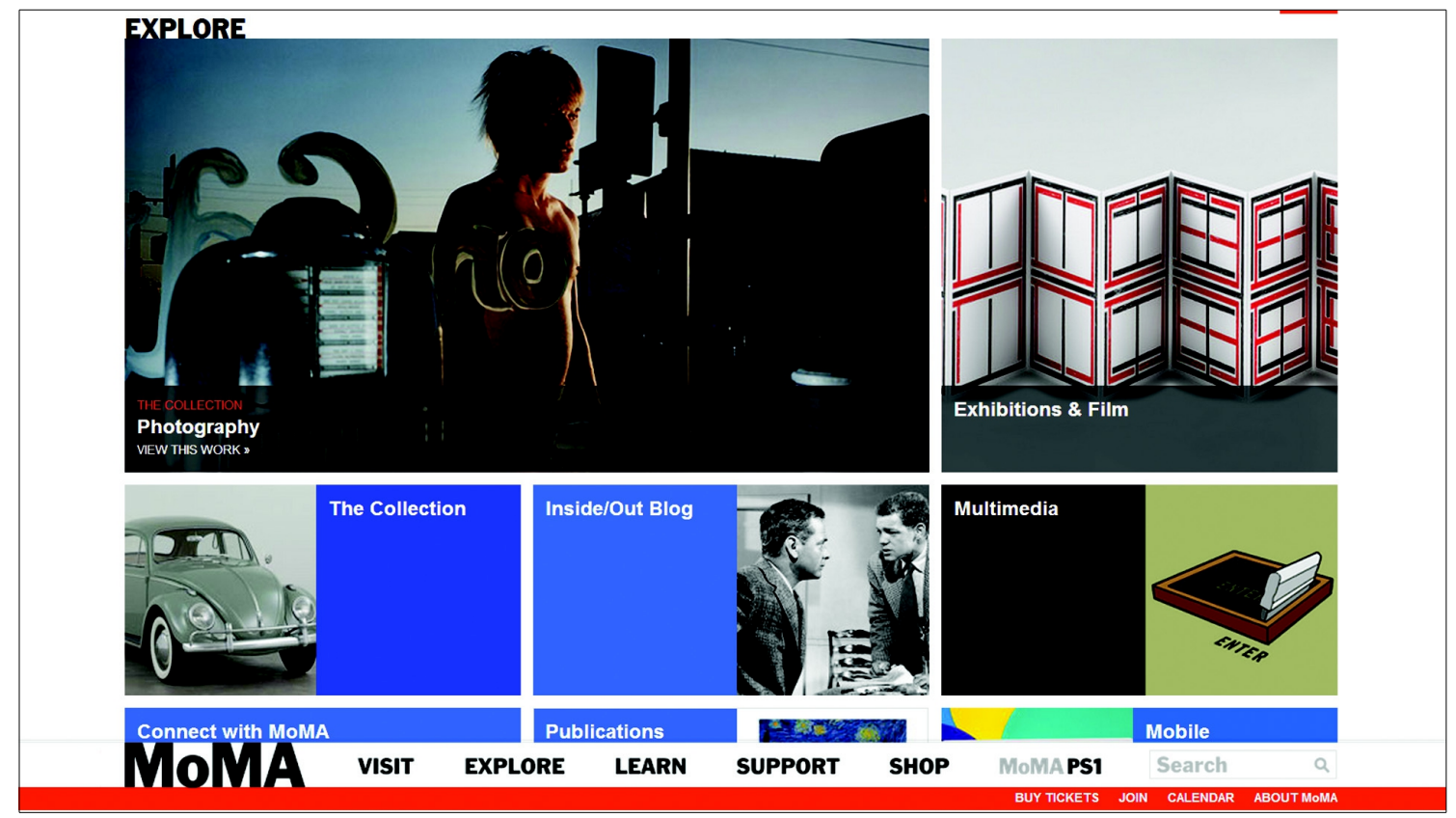

[imagem 22] Página MOMA EXPLORE.

Fonte: $\langle w w w . m o m a . o r g / e x p l o r e>$. Acesso em jul/2012.

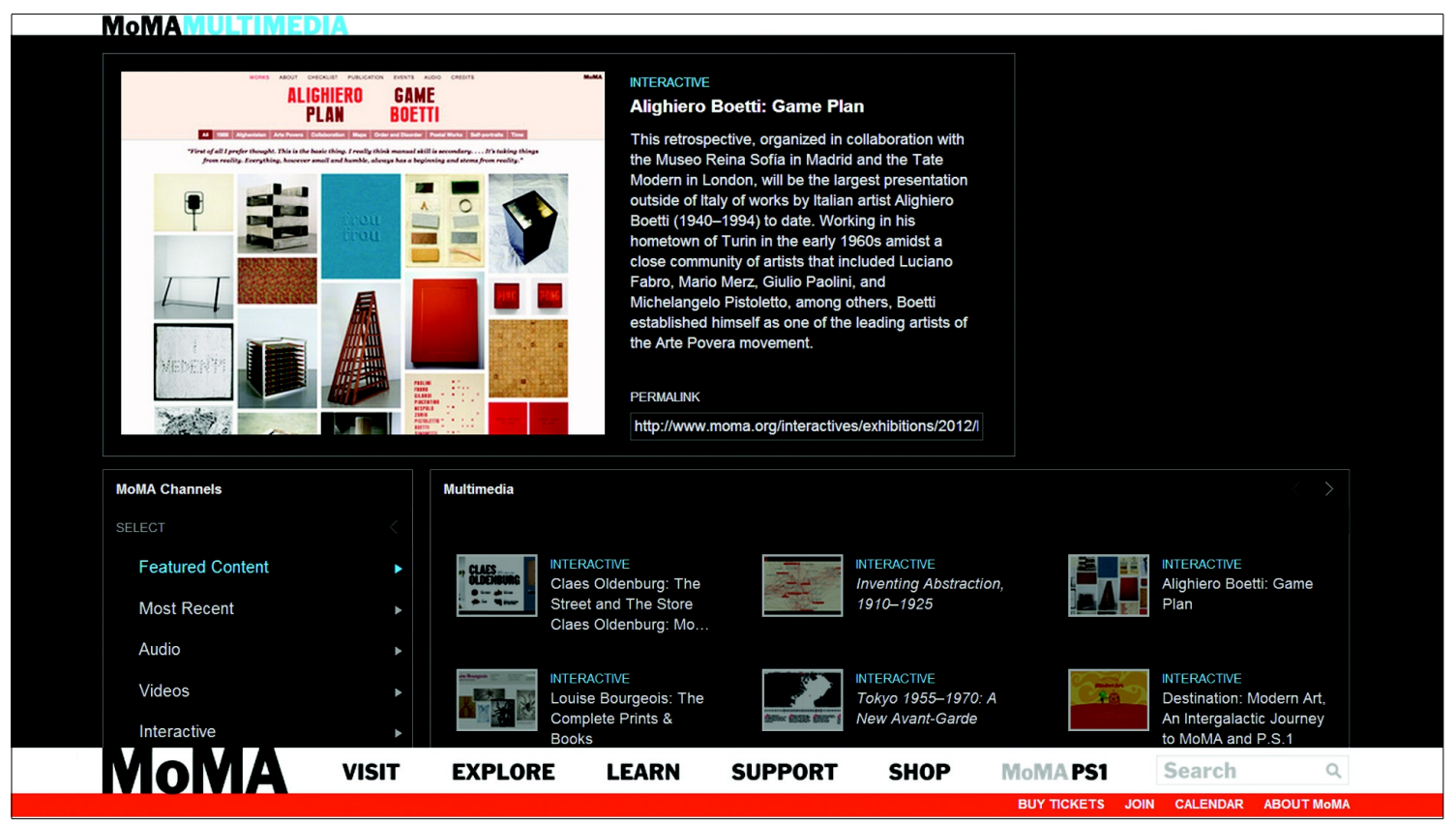

[imagem 23] Página MOMA MULTIMIDIA.

Fonte: <www.moma.org/explore/multimedia $>$. Acesso em jul/2013. 


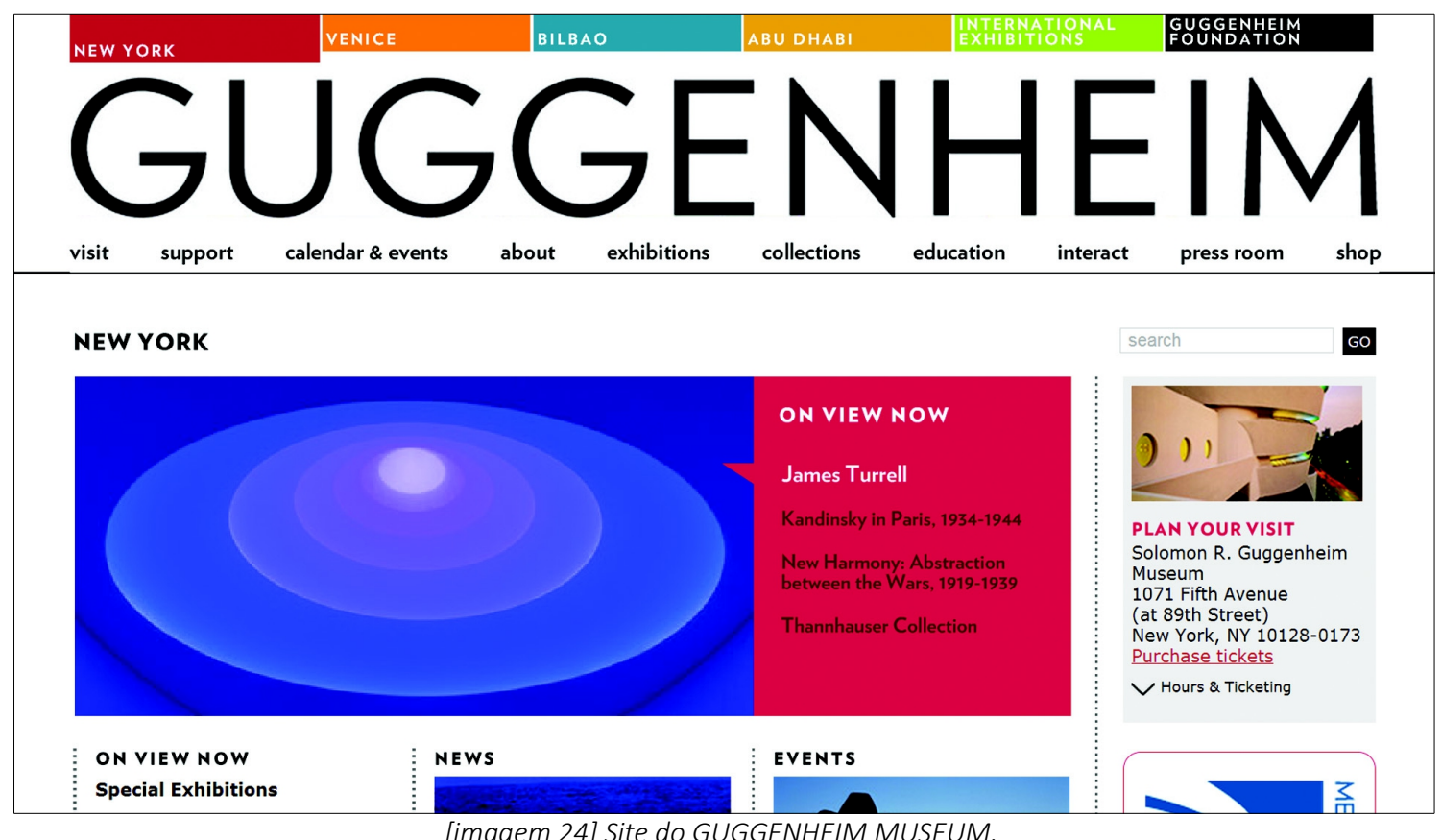

[imagem 24] Site do GUGGENHEIM MUSEUM.

Fonte: <www.quqgenheim.org>. Acesso em jul/2013.

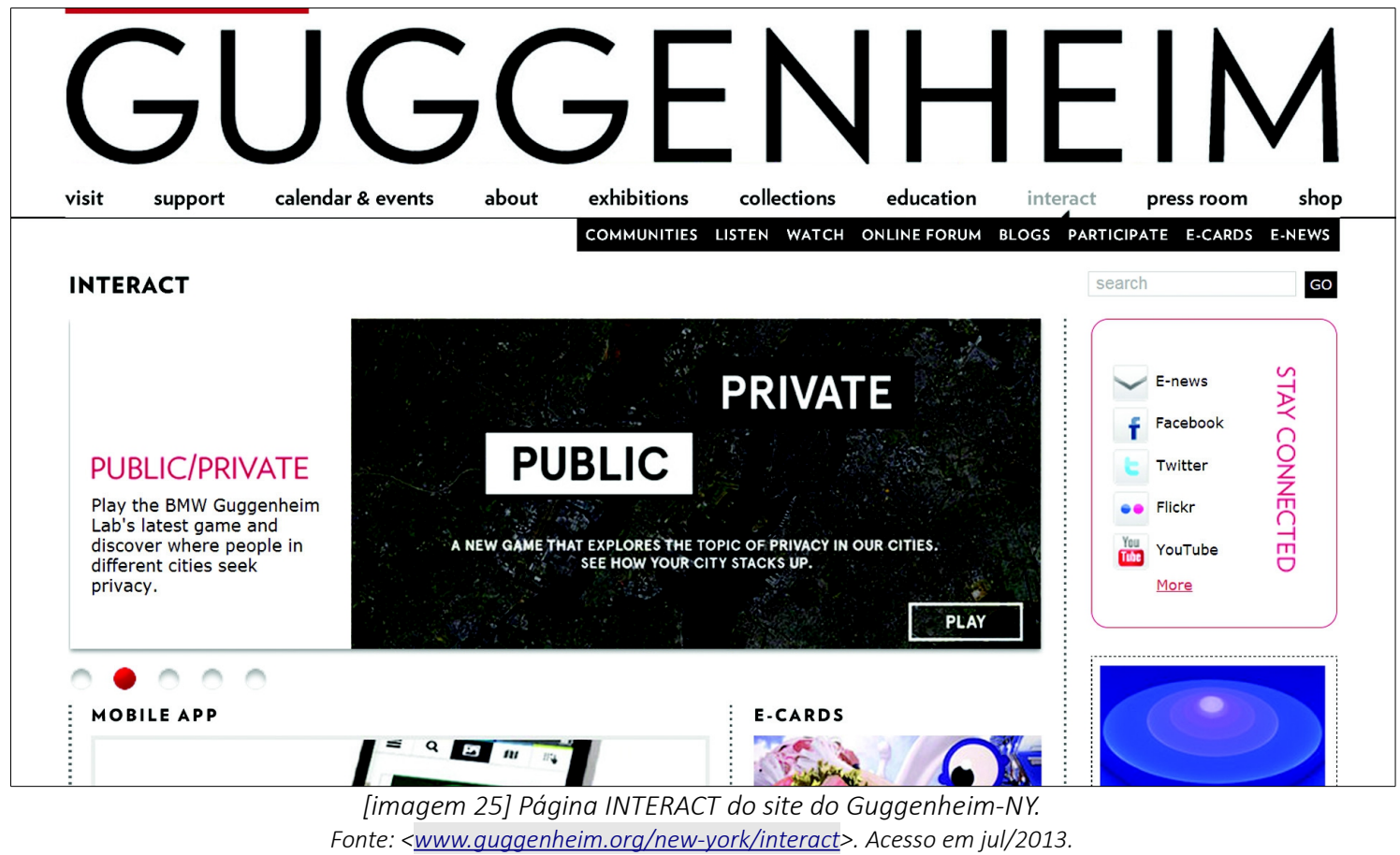




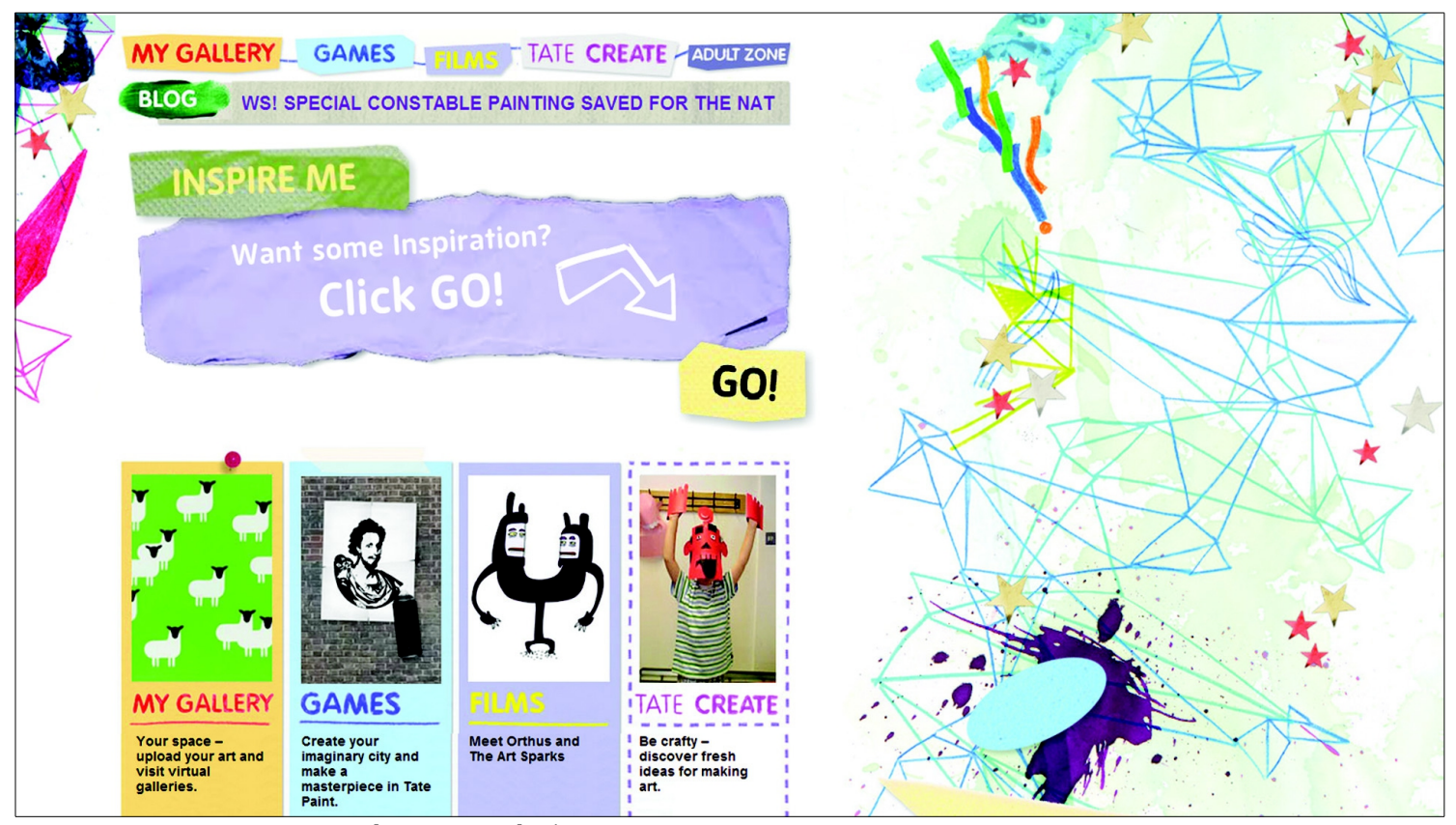

[imagem 26] Página TATE KIDS, com recursos para crianças.

Fonte: <http://kids.tate.orq.uk>. Acesso em jul/2013.

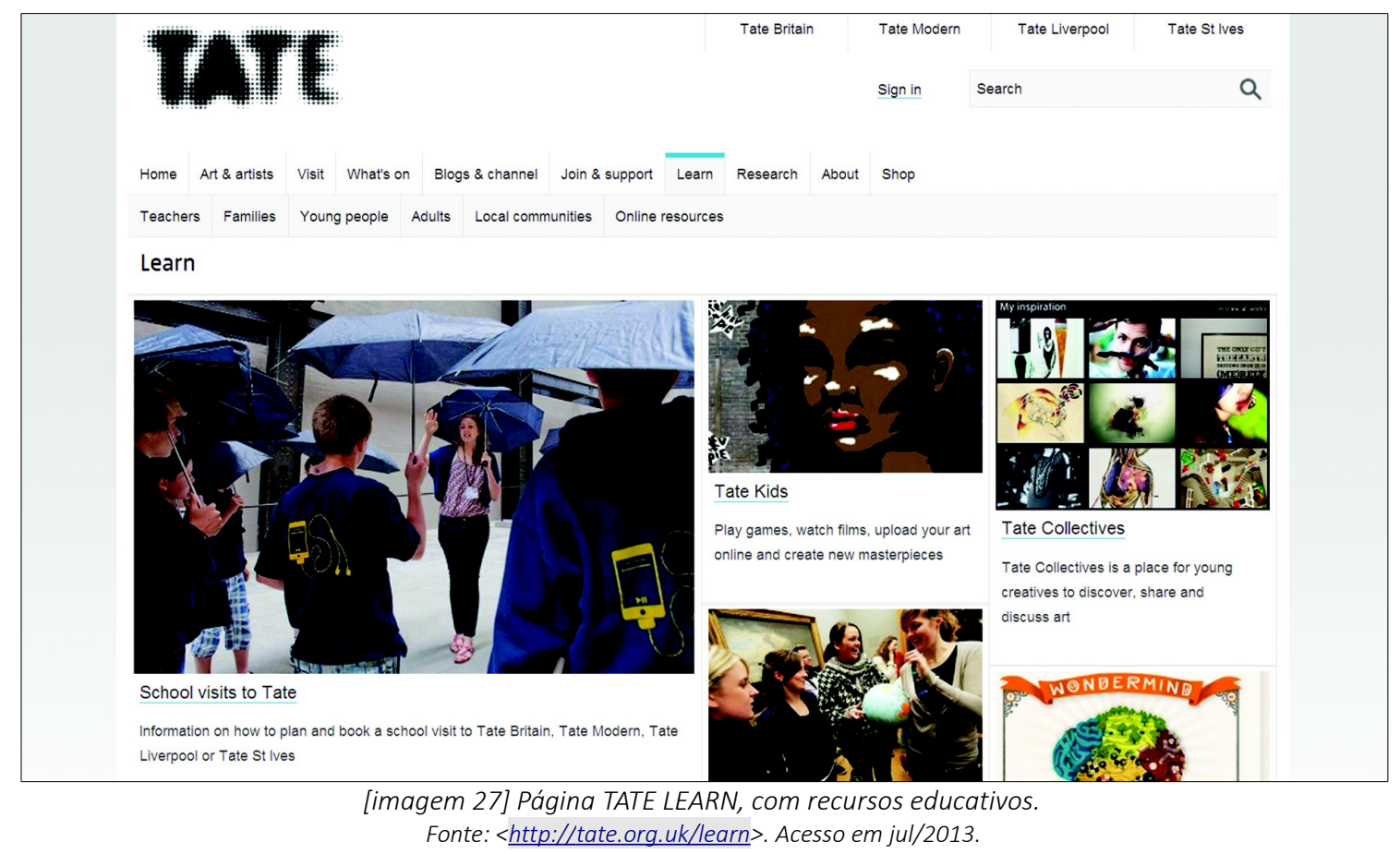




\subsection{A EVOLUÇÃO DA INTERNET E O ACERVO MUSEOLÓGICO}

Desde que começaram suas atividades na internet, as instituições culturais passaram por transformações que acompanharam a evolução da própria rede mundial de computadores. A primeira fase dos museus segue a primeira fase da internet (entre os anos 1990 e 2000), que pode ser chamada de 'readable web', ou 'web para ler'. Os websites possuíam apenas publicações de fotos e textos que eram consumidas pacificamente pelos usuários da rede. As empresas já sabiam a importância de ter uma página na internet, mas seu objetivo era apenas usa'-la para fornecer informações. Na entrada da década seguinte, surge a Web 2.0, ou 'writable web', 'web para escrever' (entre 2000 e 2010). Graças às novas tecnologias, novos modelos de comunicação apareceram. Os usuários começaram a participar ativamente na criação de conteúdos, gerando blogs, postando vídeos e outras mídias interativas. Com o grande sucesso das mídias sociais, o usuário tomou o papel central da web $^{71}$.

Em texto sobre o futuro da web, produzido pela firma de consultoria em gestão, de renome internacional, Booz\&Company, entendemos a importância da Web 2.0:

"O advento da Web 2.0 permitiu aos usuários irem além do consumo passivo de conteúdo Web, permitindo-lhes participar plenamente na geração real de conteúdo em qualquer número de novas mídias. Essa mudança tem sido uma grande benção para as empresas, permitindo-lhes obter importantes dados sobre o comportamento e as atividades dos consumidores on-line, assim, melhorando as vendas on-line e os esforços do marketing na web. No entanto, a próxima etapa da Web já está no horizonte, e vai oferecer um novo nível de conectividade, comunicações e informações sobre os clientes, incluindo as suas atitudes e preferências" ${ }^{\prime 2}$.

71 SABBAGH, Karim. ACKER, Olaf. KARAM, Danny. RAHBANI, Jad. Designing the Transcendent Web The Power of Web 3.0. @20II Booz \& Company Inc. 72 Idem, 20II. [tradução livre] 
Como é apontado, na atual década que vivemos, esperamos o aparecimento da chamada Web 3.0, ou 'semantic web', a 'web semântica' (entre 2010 e 2020). A Web 3.0 deve levar os usuários a uma experiência muito mais personalizada na rede. Ela também é chamada no texto da Booz\&Company de 'transcendent web', ou 'web transcendental ${ }^{173}$, aludindo à revolução além dos limites que proporcionará aos internautas:

"Web 3.0 - que chamamos de Web Transcendental - tem quatro elementos fundamentais:

A Web Social aperfeiçoará significativamente as capacidades de rede social, permitindo mais poderosas buscas, localizações, recomendações, e serviços similares.

A Web Semântica conectará todos os dados da Web e informações mais proximamente, permitindo busca e pesquisa baseadas em seu contexto.

A Internet das Coisas deixará as máquinas de todos os tipos conectadas à Web, comunicando-se umas com as outras e conosco, criando um rico fluxo de dados sobre a suas localizações e status.

A Inteligência Artificial, todas essas informações poderão ser agregadas e analisadas para refinar mais as buscas, recomendações e outros tipos de filtragem de informação.

O resultado para os usuários será uma experiência on-line muito mais personalizada, as empresas se beneficiarão através de um maior fluxo de dados que podem ser aplicados ao desenvolvimento de produtos, marketing e vendas, operações diárias e muito mais ${ }^{\prime \prime 4}$ [imagens 28 e 29].

Importante lembrarmos que antes de iniciar a evolução da Web 3.0, processo que vem acontecendo nesta década (2010-2020). Os museus cresceram muito no momento do desenvolvimento da Web 2.0 (2000-2010). O termo Web 2.0 data de 2004 e é tratado por muitos apenas como um modismo ou uma 'jogada de marketing', já que nenhuma atualização tecnológica de fato ocorreu na rede mundial de computadores. Ele remete a uma nova forma de ver e utilizar os serviços da internet. Aproveitando propriedades particulares existentes desde o começo da $w w w$,

73 SABBAGH, ACKER, KARAM, RAHBANI, $201 \mathrm{I}$.

74 Idem, 20II. [tradução livre] 
porém que apenas na década passada foram sistematizadas como 'regras' para a obtenção de sucesso no uso da plataforma. As principais características do modo de ver e usufruir a rede neste começo de século podem ser resumidas pela proliferação das redes sociais, a utilização da classificação por marcadores e a absorção de aplicativos inteligentes.

As redes sociais são as grandes tramas de conteúdos gerados pela exposição pública das informações de seus autores-participantes-seguidores-conexões. A classificação por marcadores permite que cada usuário da rede faça sua própria organização do imenso conteúdo disponibilizado, gerando uma grande variedade de marcações que atingem um maior número de buscas, creditada por uma maioria de pessoas. Os aplicativos inteligentes são softwares que aproveitam os efeitos de rede para se tornarem melhores quanto mais são usados pelas pessoas, aproveitando as informações deixadas por cada uma delas. Na internet de hoje, existe uma grande participação do usuário gerando, organizando, personalizando, comentando ou avaliando as informações. No chamado consumer generated media, o conteúdo é criado e divulgado pelo próprio consumidor.

Também a relação do espectador com a obra de arte mudou muito nos últimos anos devido a grande participação da tecnologia e dos computadores em nosso cotidiano. Com a possibilidade de infinita reprodução da mídia digital, as obras chegam cada vez mais próximas de um número maior de pessoas, através de réplicas originais, dos designs exclusivos e também da difusão de acervos eletronicamente, em arquivos digitais. Para Canclini, foi abandonada a ideia de que as pessoas só poderiam ter "uma relação única com a arte desde uma subjetividade incondicionada"75. A difusão da arte, atualmente, deve se voltar aos espectadores concebidos na era digital interativa, e planejar uma comunicação baseada em novas tecnologias. Sobre essa percepção, Bellido-Gant comenta o trecho: “(...) no futuro a arte será mais das massas do que nunca. O êxito de uma obra de arte se medirá em função dos seus resultados na rede (...). O mercado das massas, e não o de 'colecionismos' milionários, marcará a demanda e o êxito"76.

75 GÁRCIA CANCLINI, 2007, p. 23. [tradução livre]

76 (Julián Aragoneses, 1995). In: BELLIDO GANT, 200I, p. 37. [tradução livre] 
O novo público dos museus, tanto em seu espaço físico, mas especialmente em seu formato virtual, é o espectador multifunção que não se satisfaz apenas com a relação bidirecional de receptor da obra emitida. Ele deseja - ou apenas exerce naturalmente - a função de receptor-emissor, criador-difusor, não atuando mais de forma passiva diante ao acesso de múltiplas informações, mas gerindo e reconstruindo outros significados a elas. Para Christiane Paul, o meio digital acaba por envolver mais o público no processo curatorial e autoral: "apesar de um novo modelo precisar de tempo para se desenvolver completamente, ele sugere o potencial das tecnologias digitais como uma fonte aberta para a criação e apresentação da arte"77.

É em conjunto com a chegada da terceira geração da internet, que Ascott observa o aparecimento do terceiro tipo de museu, o Museum of the Third Kind, ou 'Museu do Terceiro Grau', e de uma nova interação entre observador e arte:

"A arte não é mais um encontro unilateral com o gosto oficial, nem um encontro secundário de interpretação pessoal, mas um encontro imediato do terceiro grau, envolvendo transformação e interatividade, onde o observador se torna parte integrante do sistema de criação. Nossa arte pode ser chamada digital, paranatural, tecnológica, online, virtual, pós-biológica ou o que seja, mas doravante, será sempre interativa. ${ }^{78 "}$

Em um terceiro momento das instituições museológicas na internet, os museus acompanham as novidades da evolução da rede e se aproximam ainda mais do seu público. Criando situações mais descentralizadas de interação dos espectadores com os bens culturais e entre si, principalmente, através de sua presença nas redes sociais e em aplicativos móveis.

77 PAUL, 2008, p.74. [tradução livre]

78 ASCOTT, 1996. [tradução livre] 


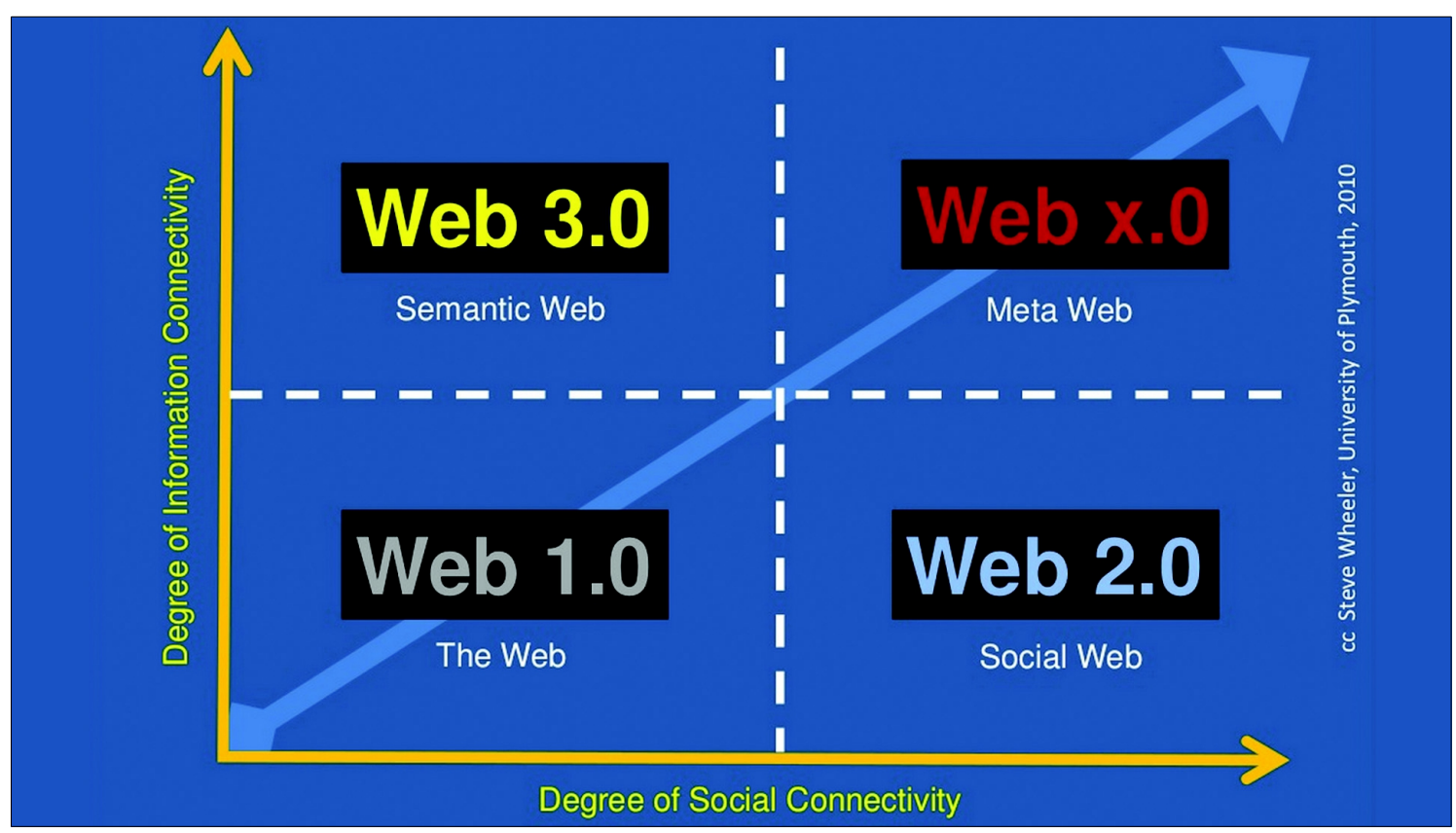

[imagem 28] Gráfico da evolução da WEB.

Fonte: <www.steve-wheeler.blogspot.com.br $>$. Acesso em jul/2013.

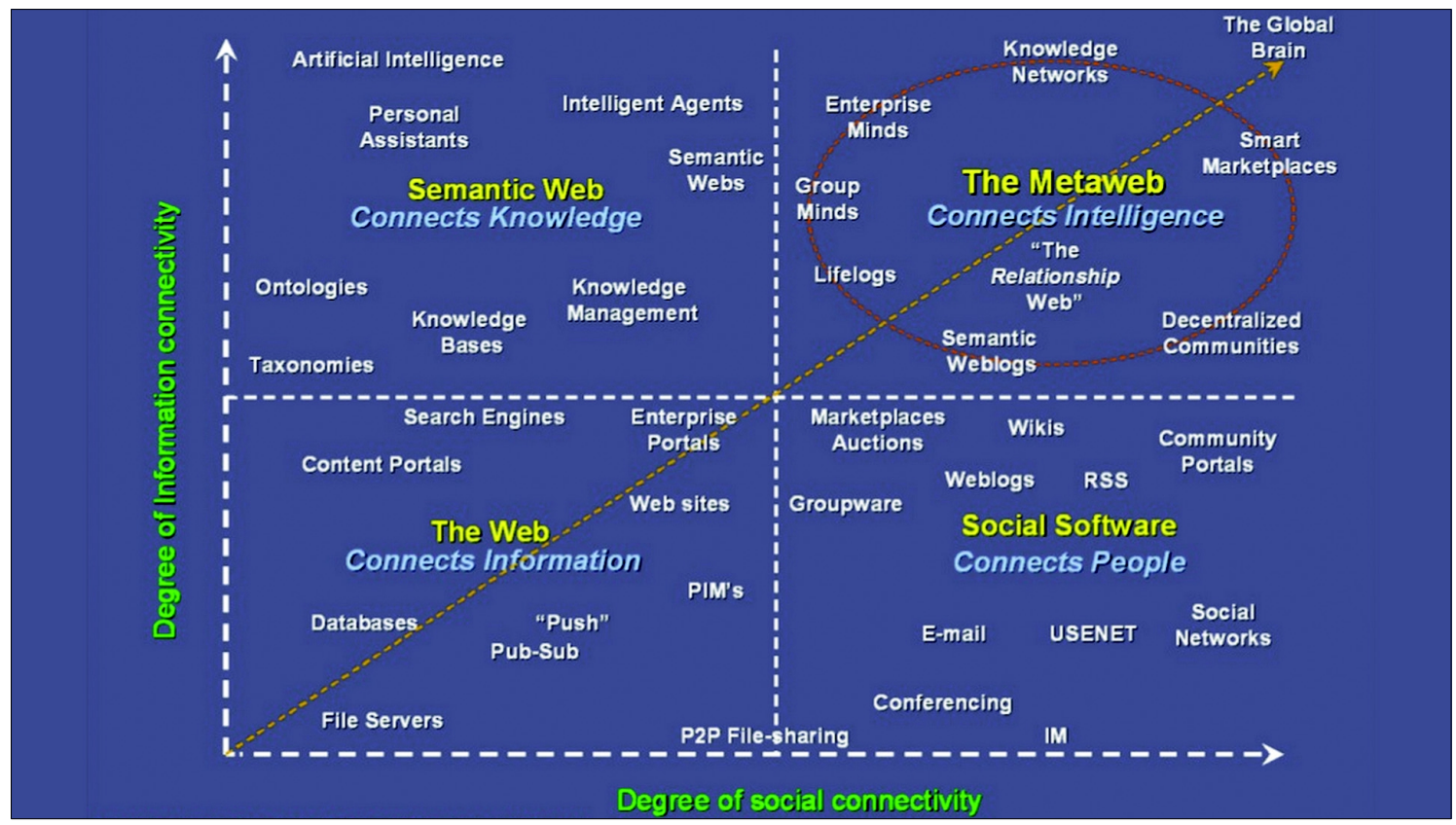

[imagem 29] Gráfico detalhado da evolução da WEB.

Fonte: <www.novaspivack.typepad.com $>$. Acesso em jul/2013. 


\subsection{A PRESENÇA DOS MUSEUS NAS REDES SOCIAIS}

A grande aproximação com o seu público foi um dos maiores ganhos das instituições culturais ao utilizar os instrumentos de comunicação interativa que a internet thes trouxe. Além de um melhor entendimento de sua comunidade e de maior interação entre os participantes de suas redes online. Bandelli nos lembra que uma das maiores características do prédio físico do museu é ser um espaço social. No entanto, uma experiência muito difícil de se criar dentro desse espaço é a interação social entre indivíduos que não se conhecem. Já em comunidades online, é muito mais comum acontecerem conversas espontâneas entre participantes, pois desaparecem as barreiras físicas ${ }^{79}$.

Atualmente, as redes sociais são a ferramenta com maior popularidade entre os usuários da rede, principalmente, entre os mais jovens. A conexão entre pessoas com os mesmos gostos e ideias acaba se fortalecendo e se multiplicando através das novas tecnologias. Recomendações, busca, localização, e outros serviços serão aperfeiçoados e personalizados utilizando a grande quantidade de informações coletadas enquanto os usuários interagem nas redes sociais ${ }^{80}$.

Observa-se que a integração da mídia social nas práticas museológicas mantém, primeiramente, uma situação na qual ela é utilizada para engajar os visitantes em votações e classificações ${ }^{81}$. Através da marcação pelas redes sociais, os curadores tem a oportunidade de ver a arte pela perspectiva da audiência e ampliar o seu entendimento sobre aquele trabalho ${ }^{82}$. As marcações digitais feitas nos acervos online

79 BANDELLI, 2010, p. 151.

80 SABBAGH, ACKER, KARAM, RAHBANI, 2011.

81 (Russo et al. 2008) In: STUEDAHL, Dagny; SMORDAL, Ole. Re-thinking museum assemblies. Universidade de Osio, Noruega, 2011. Disponivel em: <www.academia.edu>. Acesso em maio/2013.

82 CHAE, Gunho; KIM, Jungwha. Can Social Tagging Be a Tool to Reduce the Semantic Gap between Curators and Audiences? Museums and the Web 2011 Conference. Philadelphia, PA, USA. Abril, 2011.

Disponivel: $<$ www.museumsandtheweb.com/mw2011/programs/can_social_tagging_be_a_tool_to_reduce_the_s $>$. Acesso em maio/2013. 
dos museus também transmite ao setor, as tendências de linguagem do usuário, assim como transfere metadados para as obras, que podem ser usados nos acessos externo e interno da coleção ${ }^{83}$.

Todos os maiores centros artísticos já possuem uma grande presença nas redes sociais de mais relevantes da web. Segundo pesquisas ${ }^{84}$, as mídias sociais mais utilizadas pelos museus são: Facebook, Twitter, Flickr e YouTube, outras redes também muito utilizadas são Instagram, Pinterest e ArtBabble $e^{85}$. Alguns museus também criam suas próprias comunidades online, assim podem fortalecer os laços dos visitantes com a marca de sua instituição sem aproveitar a popularidade de alguma rede social específica.

No site do MOMA - NY, há um link para o blog do museu, no qual internautas recebem e interagem com notícias constantemente atualizadas sobre a instituição, organizadas entre as mais vistas, as mais recentes, ou as especialmente selecionadas pelo moderador. No blog, ainda são indicados links importantes relacionados às artes e as opções de seguir o museu em praticamente todas as redes sociais mais populares do momento, como Facebook, Twitter, Flickr, YouTube, Foursquare, além de iTunes e

83 Para a pesquisadora australiana Susan Cairs, 0 usuário classificar o conteúdo de museus com suas próprias marcações está sendo muito estudado, com a expectativa de que se possa diminuir a lacuna semântica entre curadores e espectadores. Ela explica que a marcação pelo usuário é conhecida como folksonomia, e em oposição a estrutura hierárquica e ordenada da taxonomia, tradicional ciência da classificação e da identificação: "A folksonomia é desorganizada, feita de informações sobrepostas e ambiguas. Além disso, a folksonomia não é projetada com antecedência, nem sua posse ou controle são centralizados. Em vez disso, eles são sistemas de categorização e comunicação orgânicos e colaborativos, de baixo para cima". [tradução livre]. CAIRNS, Susan. Tag! You're It! What Value Do Folksonomies Bring To The Online Museum Collection? Museums and the Web 2011 Conference. Philadelphia, PA, USA. Abril, 2011. Disponivel em: <www.museumsandtheweb.com/mw20Il/papers/tag_youre_it_what_value_do_folksonomies_bring >.Acesso em maio/2013.

84 BEALE, Nicole. A quick review of social media on museums' websites. Disponivel em: <www.theculturalheritageweb.wordpress.com/2011/09/01/what-the-websites-say >. Acesso em: maio/2013.

85 Facebook é uma rede social de contatos que em fevereiro de $201 \mathrm{I}$ era 0 site mais acessado do mundo. Twitter é uma rede social, que permite aos usuários enviar e receber atualizações pessoais de outros contatos em textos de até 140 caracteres. Flickr é um site da web de hospedagem e partilha de imagens fotográficas. YouTube é um site que permite que seus usuários carreguem e compartilhem vídeos em formato digital. Foursquare é uma rede social que permite ao utilizador indicar onde se encontra. Instagram é um aplicativo que permite aos usuários tirar fotos, aplicar um filtro e depois compartilhá-la em redes sociais. Pinterest é uma rede social de compartilhamento de fotos, inspirada em um quadro de referências. ArtBabble é um serviço de hospedagem de vídeo online para conteúdos relacionados às artes e por isso tem sido chamado de 'YouTube das artes'. WIKIPEDIA. Disponivel em: <www.wikipedia.org > . Acesso em julho/20II. 
$\mathrm{RSS}^{86}$. Essas redes também estão separadas e organizadas entre outras em uma página dentro do menu específica para elas, denominada Online Communities, [imagem 30].

$\mathrm{Na}$ corrida pelas atualizações quanto as novas regras da internet de criação e compartilhamento de conteúdo personalizado, o MOMA também criou uma plataforma própria de organização do acervo pelo usuário para fins de coleção e difusão à sua rede de conexões. No espaço My Collection, o internauta deve estar registrado em uma conta pessoal do portal, e então poderá escolher e montar sua própria coleção de obras do museu, editar e compartilhar com os amigos através das redes sociais facilmente acessadas pelo link Share, no canto superior direito da página [imagem 31].

Já o Museu Guggenheim também possui um blog com postagens de textos, vídeos e áudios sobre suas iniciativas. Além da página Communities, na qual se encontram links para as redes sociais usuais, Facebook, Twitter, Flickr e YouTube, de vários departamentos da instituição [imagem 32]. Ocasionalmente, durante a montagem de exposições, o museu organiza sessões de perguntas e respostas ao vivo, entre curadores e internautas, através das redes sociais. O público é incentivado a enviar as questões via Twitter, e-mail ou Facebook.

No website da Tate Gallery, encontramos um link para o Social Media Directory, uma página na qual a galeria nos convida para segui-la em suas redes sociais. Mais uma vez temos uma série de perfis no Twitter, Facebook, Flickr, entre outras. A Tate também desenvolve uma comunidade online própria, a Tate Collectives. Ela é apresentada como um 'espaço comunitário online para jovens criativos'. Nela, jovens artistas podem criar seu perfil, montar uma galeria virtual com seu próprio trabalho, compartilhar ideias com outros membros do grupo e desenvolver trabalhos colaborativos [imagem 33].

86 iTunes é um reprodutor de áudio (e video, a partir da versão 4.8, chamado de media player), desenvolvido pela Apple. RSS, abreviação de Rich Site Summary, é uma tecnologia que permite aos usuários da internet se inscreverem em sites que fornecem uma listagem de suas atualizações. WIKIPEDIA. Acesso em julho/20II. 
A Tate ainda alimenta, constantemente, sua página principal com vídeos dos bastidores das exposições, entrevistas de artistas e curadores. Os vídeos também são divulgados e armazenados no canal da galeria no YouTube. Porém, as atividades mais interessantes dos museus nas redes são aquelas que a utilizam em conjunto com suas práticas e exibições artísticas. No canal do Youtube da Tate Gallery, temos uma sessão chamada BMW Tate Live, na qual performances de artistas que ocorrem nas dependências da galeria são transmitidas ao vivo, dentro da rede social [imagem 34].

Em 2010, o MOMA - NY, apresentou a mostra Andy Warhol: Motion Pictures, que focava em seus filmes não-narrativos, mudos e em preto e branco, além de retratos cinematográficos que o artista fazia. O público era convidado a contribuir com a exposição, enviando seus próprios auto-retratos para uma 'atualização moderna' do processo de Warhol, através da rede social Flickr [imagem 35].

O Museu Guggenheim também utiliza o Flickr para atrair a participação do público em suas atividades. Em 2010, no seu 50 aniversário, convidou usuários da rede para um trabalho complementar à mostra 'Contemplando o Vazio: Intervenções no Museu Guggenheim'. Os participantes poderiam reimaginar a rotunda icônica do museu e enviar suas ideias através da rede social de postagens de imagens. O resultado ainda pode ser visto na página da competição no Flickr [imagem 36].

Também o Guggenheim coordenou uma das mais famosas mostras online de vídeos, a YouTube Play [imagem 37]. O evento, extremamente divulgado no site de hospedagem de vídeos, recebeu cerca de 23 mil inscrições de todo o mundo. Um grupo de curadores do museu separou 125 obras, para que os jurados escolhessem os 25 vencedores. Sobre a utilização da rede social com conteúdo gerado pelo público o museu explica em seu site:

"Nas últimas duas décadas, houve uma mudança de paradigma na cultura visual. A imagem em movimento foi totalmente absorvida em críticas práticas de arte contemporânea, e agora nós estamos testemunhando o poder da Internet para catalisar e difundir novas formas de mídia digital, incluindo o vídeo online. Com o vídeo já disponível para qualquer um produzir e assistir, quase a qualquer hora e em qualquer lugar - seja em 
telefones celulares, câmeras digitais, computadores ou tablets - ele se tornou o meio escolhido por muitos artistas. O YouTube Play reconheceu o efeito atual das novas tecnologias sobre a criatividade, e apresentou um talento excepcional trabalhando no campo cada vez maior das mídias digitais. ${ }^{87 \prime \prime}$

Aumentar o conteúdo gerado pelo usuário no espaço museológico é uma tendência que provoca debates. O acadêmico inglês John Hartley, no texto Utilizades do YouTube: alfabetização digital e a expansão do conhecimento, pensa que: "em uma sociedade de informação, contudo, o que é realmente necessário é uma rede aberta de inovação"88. Para ele, redes abertas à inovação podem aproveitar a energia criativa de toda a população, e não apenas de uma elite especializada isolada ${ }^{89}$.

Para alguns curadores e colecionadores, a ideia de postagens em redes socais serem considerados objetos de valor artístico é apenas um reflexo do momento atual. Eles acreditam que a arte deve caracterizar seu tempo e explicar o que é estar vivo hoje, e que a arte que resume o presente está na internet, e não em galerias ou museus ${ }^{90}$. As pessoas parecem estar cada vez mais deixando de contar com os museus para lhe dizerem que tipo de arte é importante, e em vez disso, através da internet, fazem essa determinação por is próprias. De qualquer forma, o papel que sempre sobrará às instituições culturais será o preservar a arte digital em toda e qualquer forma na qual ela surgir ${ }^{91}$.

870 texto 'Sobre o YouTube Play' se encontra na página explicativa do evento no site do Museu Guggenheim: $<$ www.guggenheim.org/new-york/interact/participate/youtube-play>. Acesso em julho/2013. [tradução livre]

88 HARTLEY, John. Utilidades do YouTube: alfabetização digital e a expansão do conhecimento. In: Burguess, Jean; Green, Joshua. YouTube e a revolução digital. São Paulo, Aleph, 2009. p. I72.

89 Idem, 2009, p.I72.

90 (Hugh McGrory) in: MILLER, Claire Cain. Social Media as Inspiration and Canvas. The New York Times online, 16 mar. 2011. Disponivel em: <www.nytimes.com/20II/03/I7/arts/design/flickr-photos-and-vimeo-videos-as-artwork.html>. Acesso em maio/2013.

91 (David Ross) in: MILLER, $201 \mathrm{I}$. 


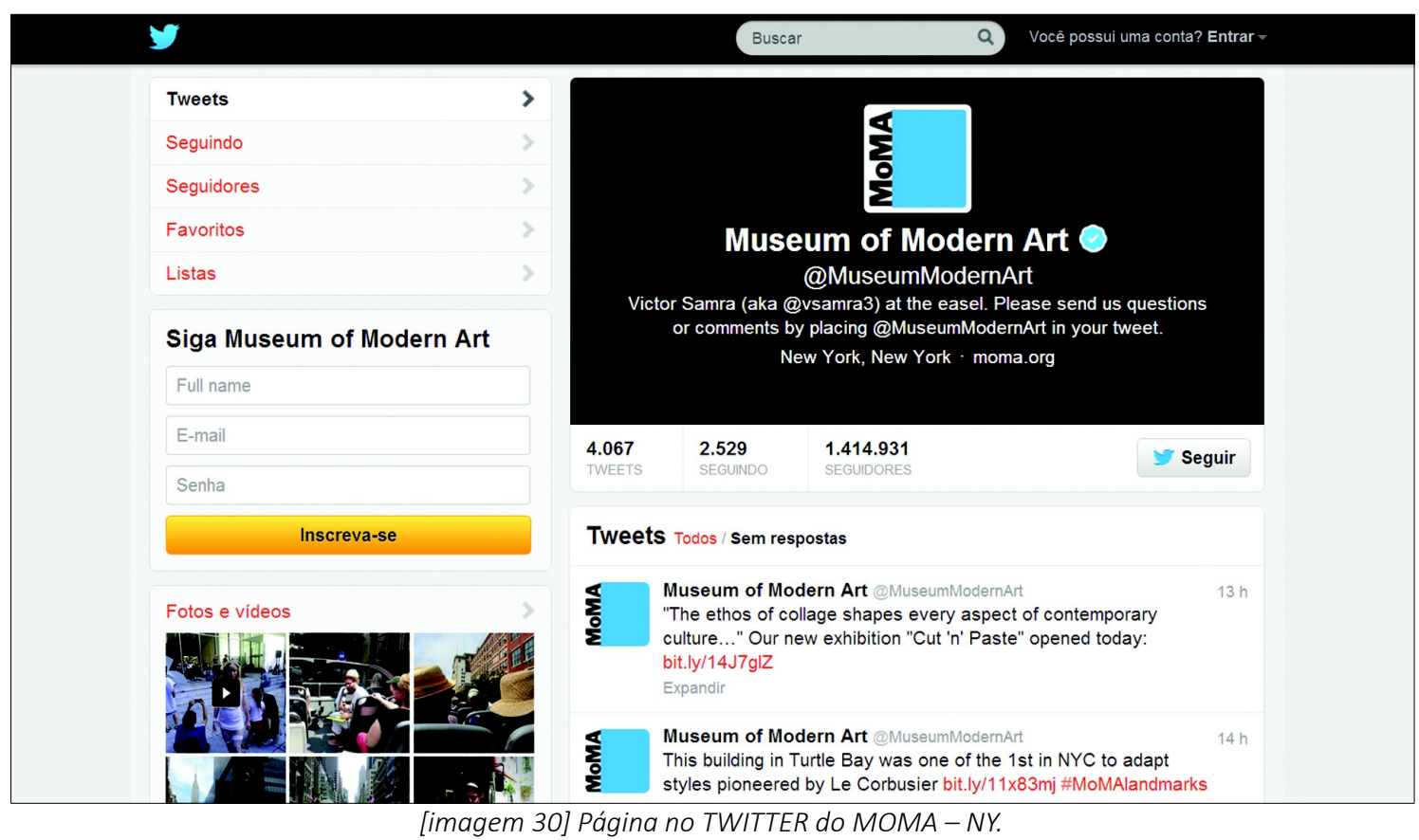

Fonte: $<$ http://twitter.com/MuseumModernArt $>$.Acesso em jul/2013.

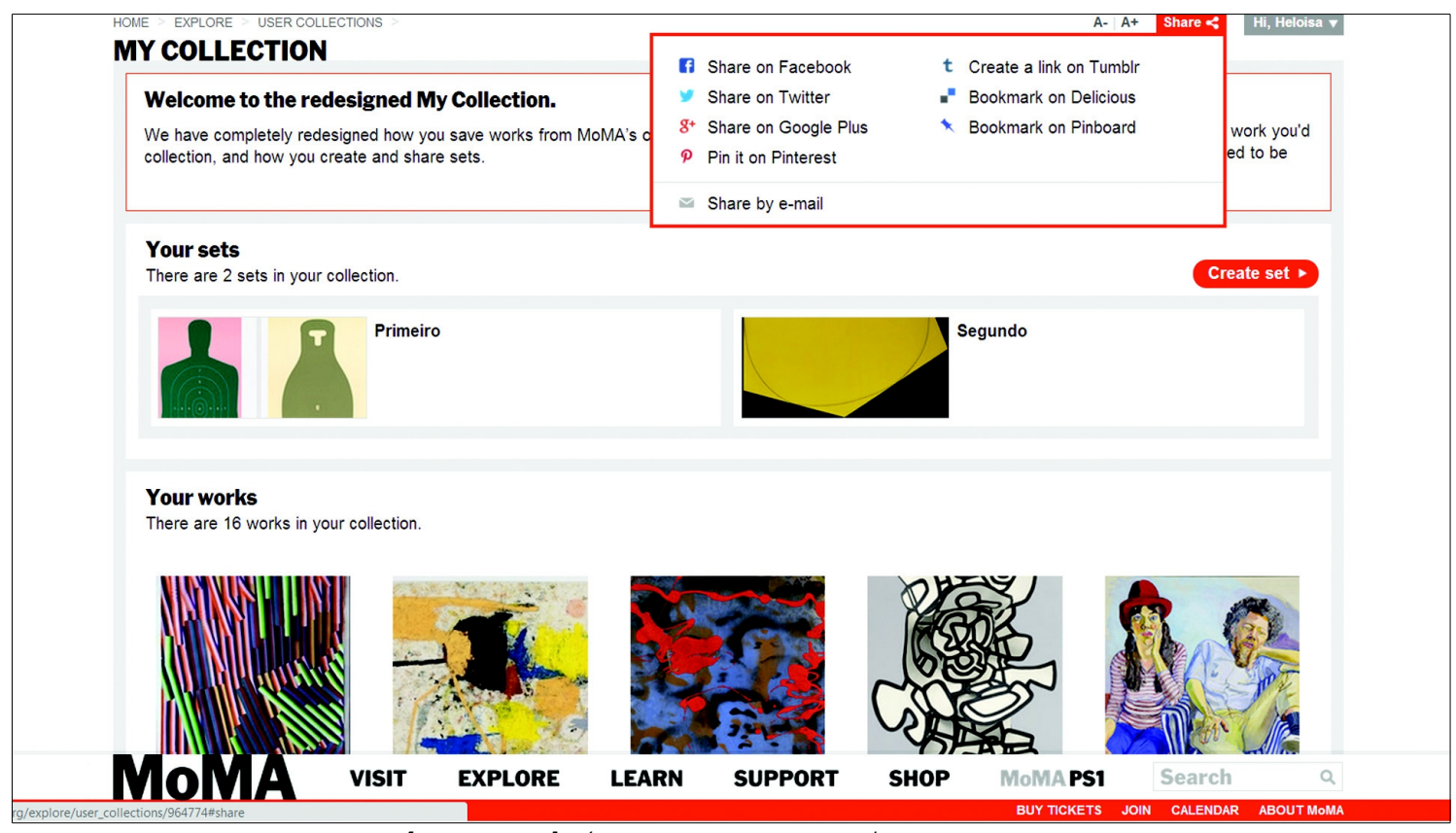

[imagem 31] Página MY COLLECTION do MOMA - NY.

Fonte: $<w w w . m o m a . o r g / e x p l o r e / u s e r$ collections $>$. Acesso em jul/2013. 


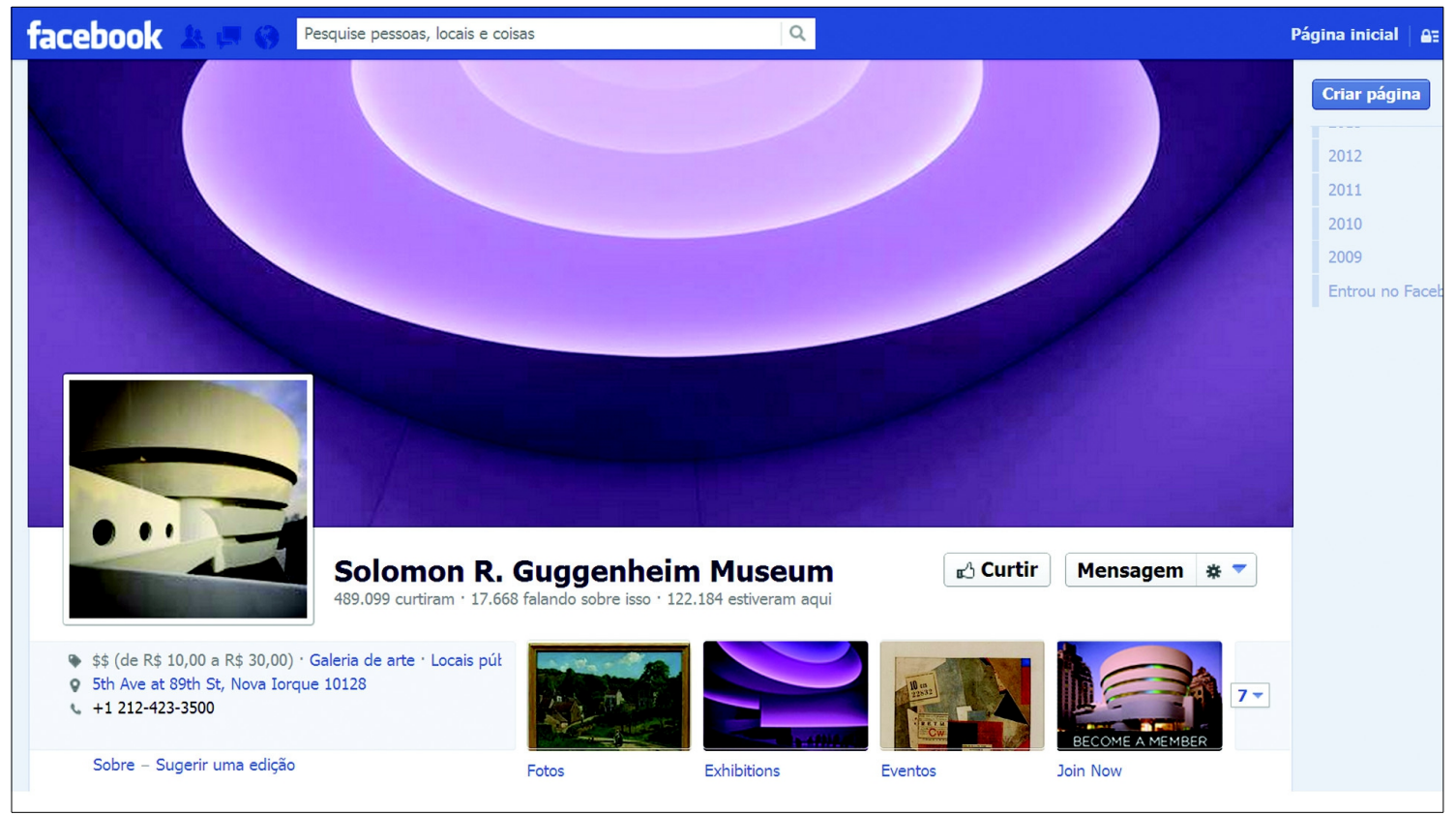

[imagem 32] Página do GUGGENHEIM no FACEBOOK.

Fonte: <www.facebook.com/quqgenheimmuseum $>$. Acesso em jul/2013.

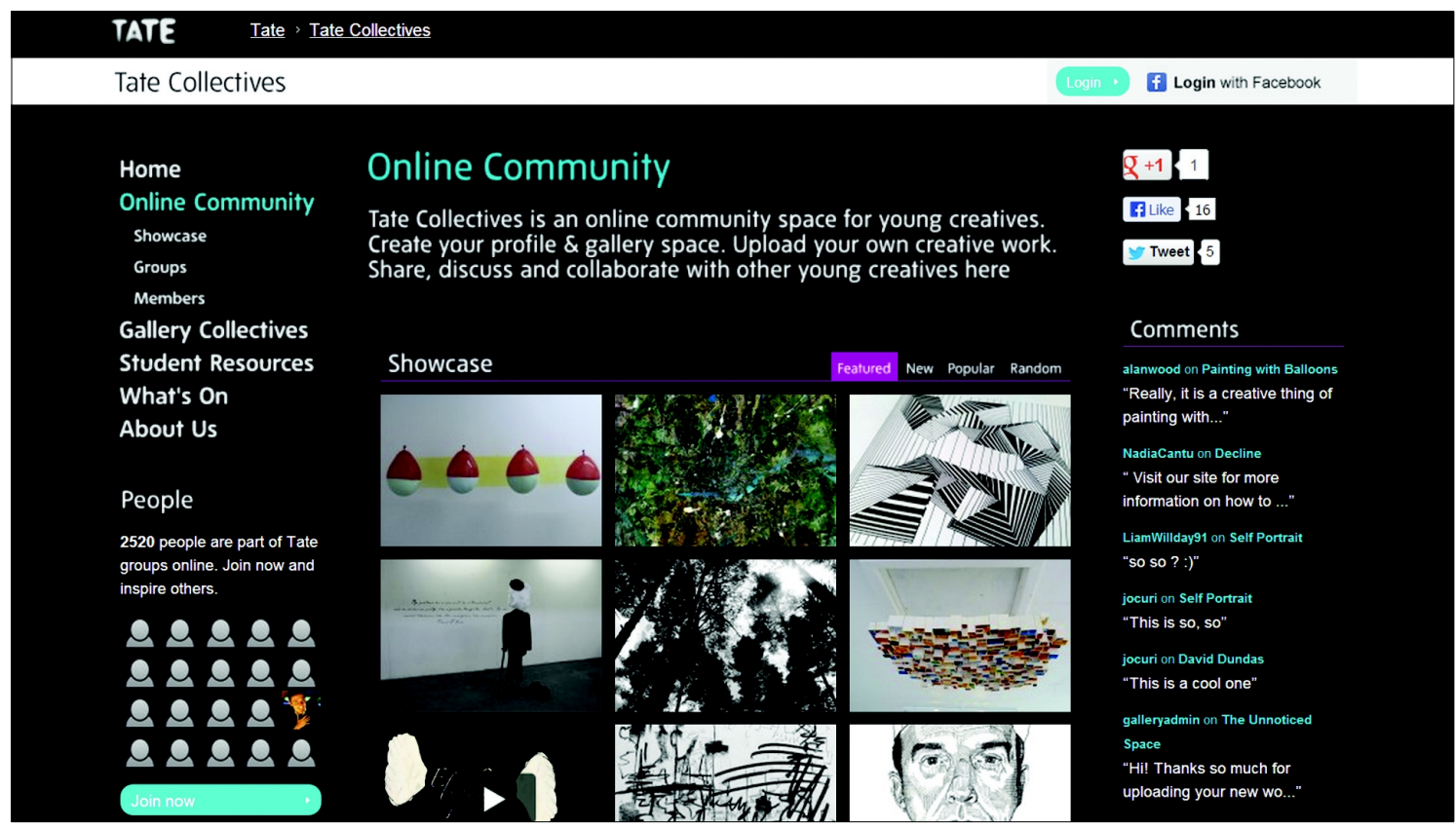

[imagem 33] Comunidade online TATE COLLECTIVES no site da TATE GALLERY.

Fonte: $<$ http://collectives.tate.org.uk>. Acesso em jul/2013. 


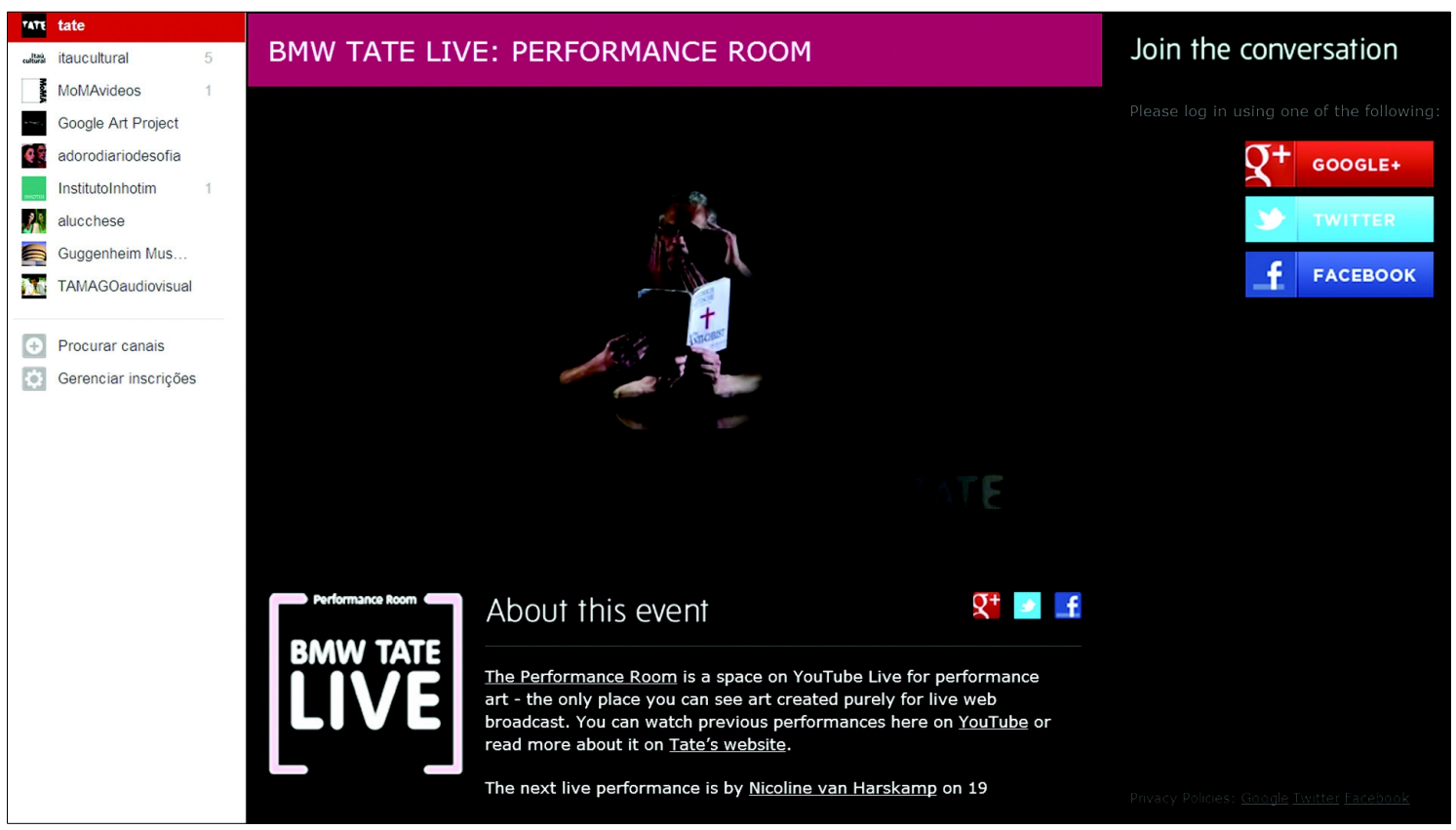

[imagem 34] BMW TATE LIVE no YOUTUBE.

Fonte: $\langle$ www.youtube.com/user/tate $>$. Acesso em jul/2013.

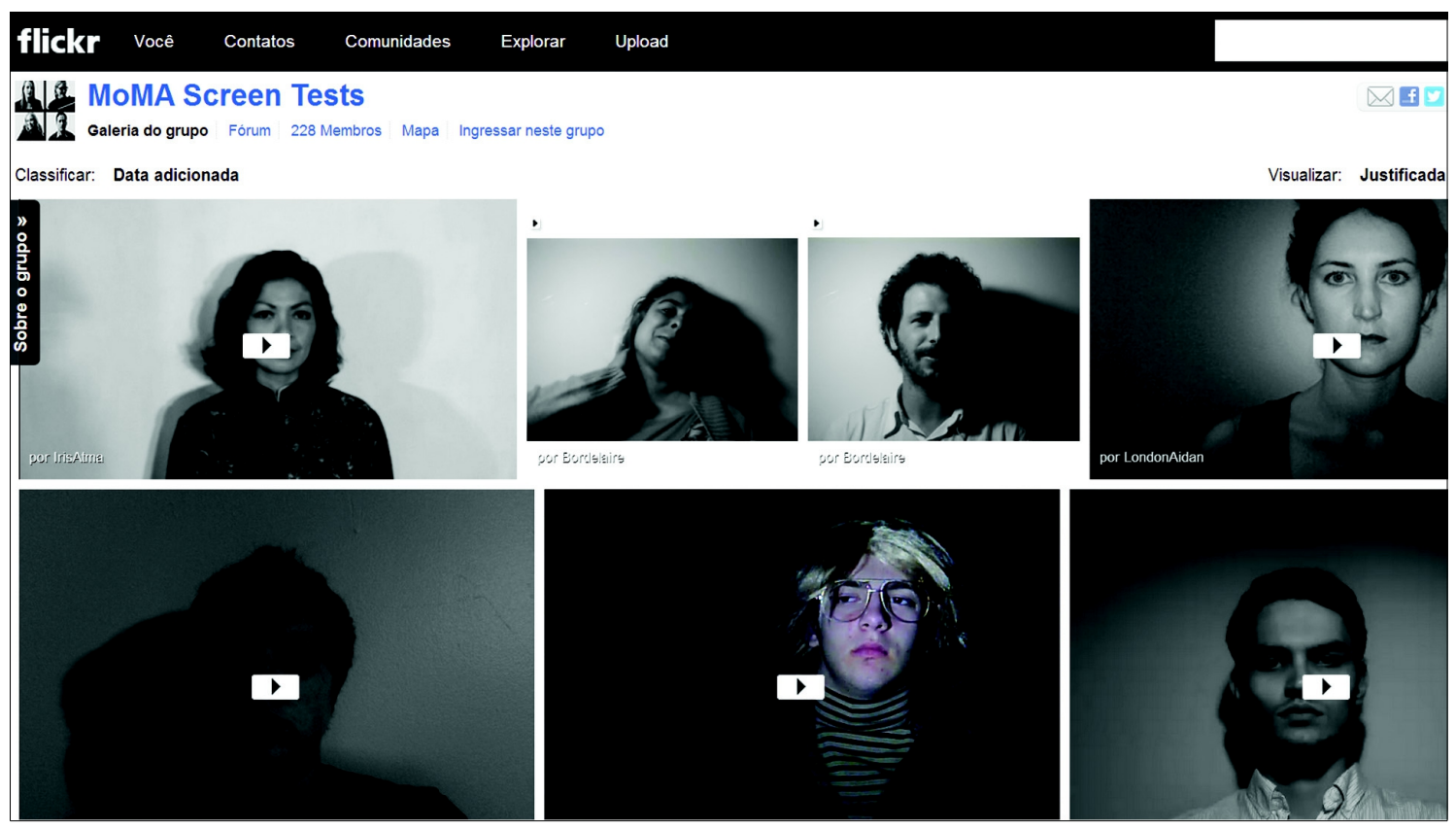

[imagem 35] MOMA SCREEN TESTS no FLICKR.

Fonte: $\langle$ www.flickr.com/search/?q=momasc90 $>$. Acesso em jul/2013. 


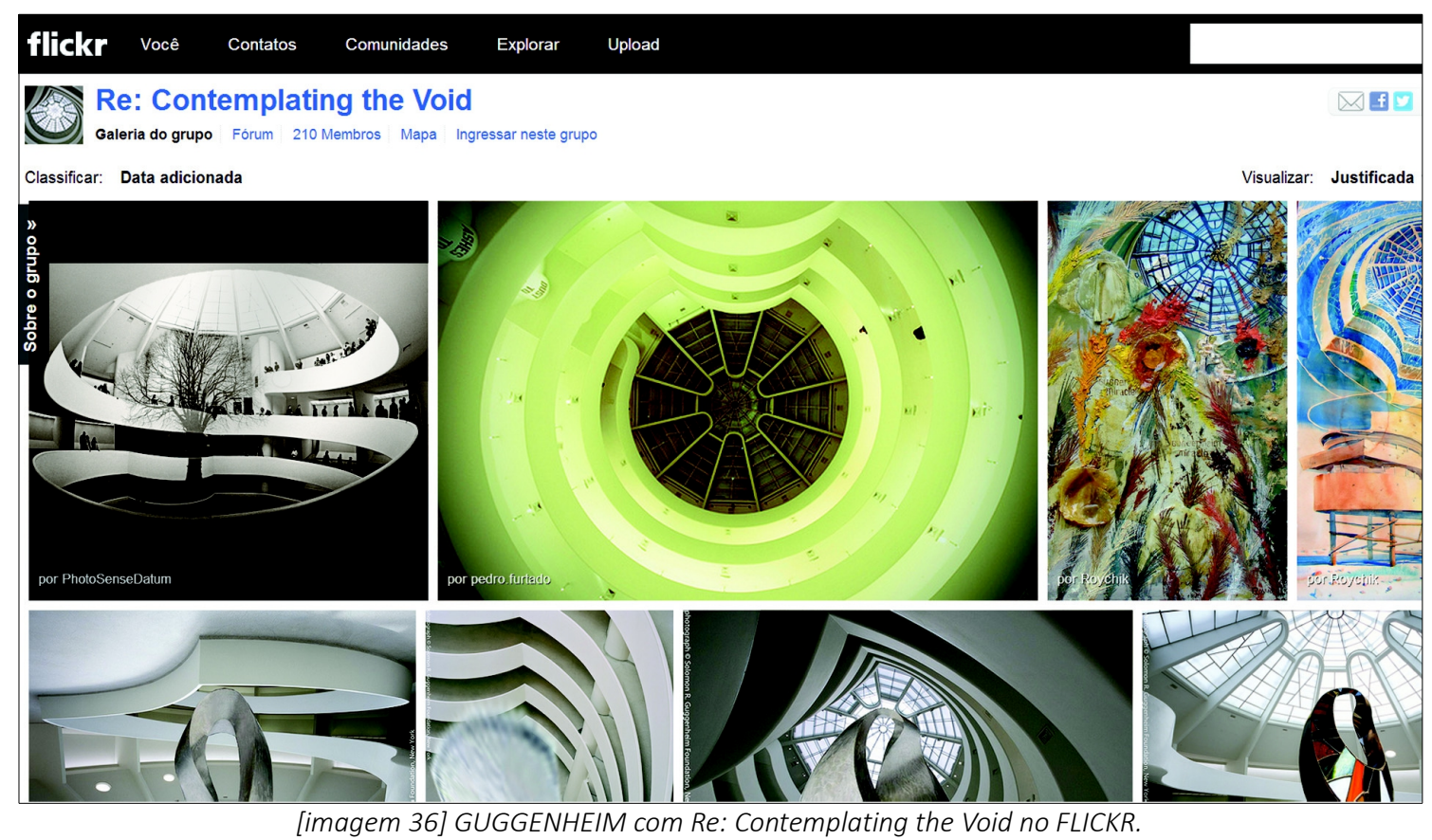
Fonte: $<w w w$.flickr.com/groups/recontemplating $>$. Acesso em jul/2013.

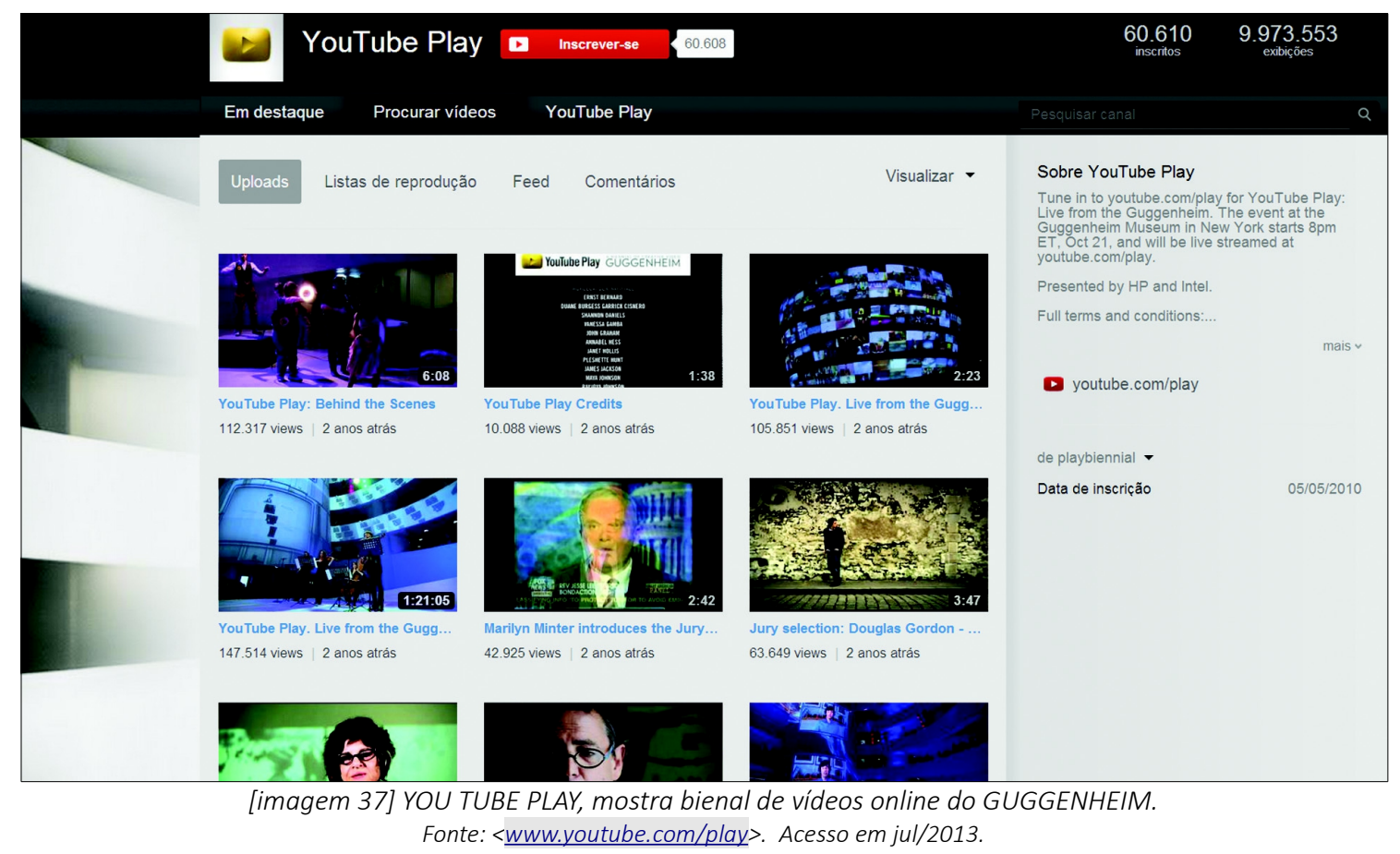




\subsection{MÍDIAS MÓVEIS DENTRO E FORA DOS MUSEUS}

\subsection{OS DISPOSITIVOS COMO EXTENSÕES DO HOMEM}

O pesquisador canadense Marshall Mcluhan, ainda na década de 60, foi quem primeiro apontou o interesse do ser humano em criar tecnologias e invenções que complementassem e ampliassem a si próprios. Descrevendo o homem como "amante dos gadgets", ele aponta a crescente utilização de dispositivos como extensões da pessoa e seus sentidos ${ }^{92}$. Um visionário à sua época, Mcluhan previa o que hoje fica claro ao observarmos a relação das pessoas com seus computadores pessoais, ou especialmente, com seus telefones inteligentes.

Toda a forma dos indivíduos se relacionarem com o mundo foi modificada com a popularização dos aparelhos de telefonia móvel conectados a internet e o amplo acesso a redes de banda larga. As pessoas são facilmente seduzidas pela possibilidade de estarem sempre conectadas a seus e-mails, redes sociais ou aplicativos de geolocalização, sem abrir mão da mobilidade ${ }^{93}$.

O que observamos agora é uma nova atitude dentro do espaço urbano. O homem passa a ter outra relação com o ambiente pelo uso de tecnologias móveis. Por exemplo, é possível ter acesso a informações sobre um estabelecimento, antes de entrar nele e decidir de antemão, se vale ou não a pena visitar o lugar. O pesquisador da cibercultura André Lemos fala da atual dinâmica dentro do espaço físico e de uma nova forma de mobilidade, a "mobilidade informacional":

"A mobilidade por fluxos de informação, que altera e modifica a mobilidade pelos espaços físicos da cidade, como a possibilidade de acesso, produção e circulação de informação em tempo real. (...) Mobilidades informacionais criam gestões fluidas do tempo e, consequentemente, do espaço. Não há

92 McLUHAN, Marshall. 0 amante de gadgets. In: Os meios de comunicação como extensão do homem. São Paulo: Cultrix, 1964, p. 59.

93 GABRIEL, Martha. Tecnologias Móveis: Amigos ou Inimigos Disfarçados? In: Apropriações do (In) Comum-Espaço Público e Privado em Tempos de Mobilidade, E-Book, Org: G. Beiguelman, Lucas Bambozzi, Marcus Bastos e Rodrigo Minelli, mai/2009. p. 66. 
descolamento entre os espaços e as correlatas mobilidades, mas a intersecção entre espaço eletrônico e espaço físico, criando os territórios informacionais ${ }^{\prime \prime 4}$.

O acadêmico também faz uma interessante comparação entre as formas de deslocamento através do "território informacional" com o nomadismo de sociedades antigas. Ele apresenta os "novos nômades high-tech" que passam de um ponto a outro do espaço buscando conexões wireless: "O território do Beduíno high-tech não é o deserto, mas o território informacional criado pela intersecção do espaço físico com o ciberespaço nas metrópoles contemporâneas. (...) Munidos de tecnologias sem fio como laptops Wi-Fi e smartphones, aliam mobilidade física no espaço público com a mobilidade informacional pelo ciberespaço" ${ }^{\prime \prime 5}$.

Lemos ainda, acrescente à ideia de mobilidade informacional, a capacidade de deslizamentos por bens simbólicos, mensagens ou informações ${ }^{96}$. Ele sugere um novo contato com os bens culturais proporcionado pelas tecnologias móveis:

"O deslocamento pelos bens simbólicos era imóvel, na maioria das vezes, em espaços privados, sem possibilidade de emissão massiva. Hoje, no começo do século XXI, os territórios informacionais (agora telemáticos e digitais) estão em expansão planetária, utilizando ferramentas ubíquas e permitindo uma mobilidade informacional (emissão e recepção de informação) acoplada a uma mobilidade pelo espaço urbano. [...] Essa nova mobilidade informacional, a mobilidade tecnológica (a dos dispositivos), pode permitir uma nova maneira de compreender, dar sentido e criar vivências no espaço das cidades contemporâneas."

Assim, vemos os museus iniciarem sua inclusão nesse novo ciberespaço informacional acessado pelos dispositivos móveis. Ao possibilitar o acesso remoto às suas informações, as instituições culturais pretendem ampliar a experiência para seus espectadores on-site e off-site, aqueles dentro e fora dos museus.

94 LEMOS. André. Cidade e Mobilidade. In: Apropriações do (In) Comum - Espaço Público e Privado em Tempos de Mobilidade, E-Book, Org: G. Beiguelman, Lucas Bambozzi, Marcus Bastos e Rodrigo Minelli, mai/2009. p. 53.

95 Idem, 2009, p. 55; FOST, Dan. Where neo-nomads' ideas percolate - New 'bedouins' transform a laptop, cell phone and coffee house into their office. San Francisco Chronicle online, I mar. 2007. Disponivel: <www.sfgate.com/default/article/WHERE-NEO-NOMADS-IDEAS-PERCOLATE-New-2610920.php >.

96 Idem, 2009, p. 59 


\subsubsection{APLICATIVOS MÓVEIS ON-SITE E OFF-SITE}

Ao longo dos últimos anos, os museus aprenderam a criar seus próprios conteúdos e publicá-los em múltiplas plataformas. Um incontável número de aplicativos para mídias móveis tem sido desenvolvidos por museus para atingir espectadores off-site, ou para ajudá-los em visitas on-site. A opção do uso da internet em aparelhos móveis tem substituído processos tradicionais como o audioguia ou a mídia impressa e tem trazido mais oportunidades e desafios ${ }^{97}$.

O uso de dispositivos do próprio visitante durante programas dentro dos museus, que começou com podcasts e audioguias para celulares há alguns anos, teve um grande aumento de popularidade com o surgimento do smartphone. No entanto, algumas questões são apontadas, em especial: Como prover, proteger, e manter os instrumentos adequados para os visitantes que não possuem - ou não querem usar o seu próprio aparelho? ${ }^{98}$

As possibilidades do uso de uma mídia móvel durante a visita ao museu são diversas. O visitante pode, por exemplo, encontrar mais facilmente a localização de exposições específicas, de um espaço para café, dos sanitários ou da saída. Ainda é citada a vantagem do espectador não precisar passar por filas, como as para retirar um audioguia ou para ler textos descritivos nas paredes, já que basta acessar o telefone pessoal em suas mãos ${ }^{99}$.

Dentro do espaço do museu, além de facilitar a visualização de mapas do local, aplicativos móveis também são usados para fornecer informação e interação extras com as exposições visitadas. Através de mobile tags ${ }^{100}$, como o QR Code ${ }^{101}$ por

97 BURNETTE, Allegra; CHERRY, Rich; PROCTOR, Nancy; SAMIS, Peter. Getting On (not Under) the Mobile 2.0 Bus: Emerging Issues in the Mobile Business Model. Museums and the Web $201 \mathrm{I}$ Conference. Philadelphia, PA, USA. Abril, $201 \mathrm{I}$.

Disponivel em: <www.museumsandtheweb.com/mw20II/papers/getting_on_not_under_the_mobile_20_bus>.

98 Idem, $201 \mathrm{I}$.

99 TEDESCHI, Bob. Apps as Tour Guides Through New York Museums, Step by Step. The New York Times online, 8 set. 2010. Disponivel em: <www.nytimes.com/2010/09/09/technology/personaltech/09smart.html? $r=2 \&$ emc=etal\& $>$

100 Mobile tagging é o processo de fornecer dados de leitura para dispositivos móveis através de etiquetas, geralmente um código de barras. WIKIPEDIA. Acesso em: jul/2013.

I0I QR Code (abreviação de Quick Response Code) é a marca de um tipo de matriz de código de barras. Um código de barras é uma marca opticamente legivel por máquina que está anexada a um item e que registra informações relacionadas a esse item. WIKIPEDIA. Acesso em: jul/2013. 
exemplo, o visitante pode acessar links na internet relacionados a obras e interagir com a exposição nas redes sociais, criando assim, "ligações entre o mundo tangível físico e o mundo online digital” ${ }^{102}$. Dessa forma, o espaço expositivo é ampliado para um espaço virtual além dos muros do museu, o que modifica, inclusive, a forma atual de se pensar o projeto de exposições.

De qualquer forma, fica claro para a maioria dos profissionais de museologia que o maior valor das mídias móveis é na criação de programas desenvolvidos como parte de um ecossistema maior de produtos, plataformas e iniciativas de superação ${ }^{103}$. Mas também, devido ao número de visitantes off-site ainda ser muito superior aos espectadores on-site, o potencial dos dispositivos portáteis é aproveitado no desenvolvimento de aplicativos para serem usados longes dos museus, como exposições virtuais, jogos educativos, coleções compartilháveis, entre outros.

O museu Guggenheim nos apresenta a possibilidade de baixar aplicativos para aparelhos com sistemas operacionais iOS e Android ${ }^{104}$. O programa promete melhorar a experiência do visitante dentro da instituição e também prover materiais a serem descobertos e estudados fora dela. São oferecidas informações sobre a coleção, o edifício, mostras, calendário e eventos, além de opções de customização, em cinco idiomas. Para a exposição Maurizio Catellan: All ${ }^{105}$ (2011-2012), uma retrospectiva do artista italiano, o museu desenvolveu seu primeiro aplicativo móvel multiplataforma. A exibição consistia em 128 obras penduradas no teto do edifício. Propositalmente, nenhuma parede foi utilizada na montagem, o que levou à busca de uma nova forma para apresentar as informações que antes ficavam em textos próximos às obras. Um aplicativo móvel para iPhone, iPad e Android foi então criado [imagem 38]. Os visitantes podiam aprender mais sobre a obra no contexto da carreira do artista, com textos, vídeos e áudios, entre outras características que permitiram que os usuários

102 GABRIEL, 2009, p. 67.

103 BURNETTE, CHERRY, PROCTOR, SAMIS, $201 \mathrm{I}$.

104 Página do Guggenheim | Visit|App. Disponivel em: <www.guggenheim.org/new-york/visit/app >. Acesso em julho/2013.

105 A mostra Maurizio Catellan: All ficou exposta no Guggenheim-NY entre 4 de novembro de 2011 e 22 de janeiro de 2012. Disponivel em: <www.guggenheim.org/new-york/exhibitions/past/exhibit/3961>. Acesso em maio/2013. 
recriassem a sua experiência antes ou depois da visita. O aplicativo mostrou ser uma ferramenta interativa importante, não só para os visitantes no local, mas também para quem quisesse experimentar a exposição, mas não pudesse ir ao Guggenheim ${ }^{106}$.

Na webpage do MOMA-NY ${ }^{107}$, na seção MoMA mobile, está a área mais atual do site. Nela são disponibilizados para download gratuito aplicativos para iPhone e Android, no qual o usuário tem acesso a informações exclusivas, como: calendário de exposições e eventos, audiotours e uma base de dados com todos os artistas e obras do museu [imagem 39]. Também há dois aplicativos para iPad. Um para adultos, no qual é possível acessar mapas multimídias de algumas exposições, assistir vídeos em alta resolução, ler inúmeras publicações do museu em formato ibook e compartilhar esses arquivos com colegas através de redes sociais. Outro para crianças, no qual usuários a partir de sete anos podem criar suas próprias obras de arte e aprender sobre artistas consagrados. O museu também apresenta para o iPad, a possibilidade de baixar gratuitamente um aplicativo que apresenta suas publicações online, ou comprar pela iBookstore livros digitais com uma experiência multimídia aprimorada.

No site da Tate Gallery, encontramos nada menos que dezesseis aplicativos para dispositivos móveis ${ }^{108}$. Além de apps específicos para algumas exposições em cartaz e guias sobre o trabalho de artistas reconhecidos, também temos jogos para crianças e para adultos. No Tate Trumps App, o usuário é convidado a montar sua própria galeria, ganhando o máximo de pontos para competir com os amigos. Em Magic Tate Ball, a pessoa balança o aparelho celular e o aplicativo indica uma obra especial próxima ao usuário utilizando serviços de geolocalização. A galeria inglesa também disponibiliza aplicativos que permitem fazer brincadeiras com as obras de Magritte e Muybridgizer e postá-las em redes sociais. Para iPad, o museu oferece entre outros apps, a versão digital de sua revista quadrimestral Tate Etc. e um dicionário de termos técnicos de arte, o Tate Guide to Modern Art Terms [imagem 40].

106 MUSEUMS AND THE WEB. <www.museumsandtheweb.com/mw2012/best/mobile/maurizio cattelan all app $>$. Acesso em maio/2013.

107 Página do MoMA|Explore|Mobile. Disponivel em: <www.moma.org/explore/mobile/index >. Acesso em julho/2013.

108 Página da Tate Gallery|Blogs\&channel| Apps. Disponivel em: $<$ http://tate.org.uk/context-comment/apps $>$. Acesso em julho/2013. 
Apesar de não ter um grande retorno financeiro com o investimento em mídias móveis, os museus continuam com um trabalho pioneiro na utilização dessa nova tecnologia. O investimento é justificado pela capacidade única das plataformas móveis de atender as missões do museu, oferecendo maiores possibilidades de difusão, acessibilidade, educação e interpretação. Além de facilitar outras fontes de receita através da internet (como as vendas online de catálogos e souvenirs). De qualquer modo, as mídias móveis também estão revolucionando a forma dos museus de fazer negócios. Como o público espera cada vez mais informações e experiências sob sua própria demanda, o mercado de conteúdo mobile para museus está crescendo. Esse conteúdo não será apenas produzido pelos próprios museus, mas também por empresas terceirizadas e por grupos independentes ${ }^{109}$.

O site holandês Museum App ${ }^{110}$, lançado em parceria com o Museu de Amsterdã, permite que qualquer espaço museológico crie seu próprio aplicativo. Através do produto, pequenos museus podem criar tours interativos em espaços externos e internos para serem acessados via smartphone. Ele consiste em um ambiente de edição online com o qual os passeios podem ser facilmente montados e publicados, através do uso de fotos, vídeos e textos ligados a obras, locais da cidade, ou a sala de uma galeria [imagem 41].

Ainda existem as produções independentes, de pequenos museus e galerias inteiramente planejados para o acesso via celular. O Mobile Online Museum of Contemporary $\operatorname{Art}^{111}$ (2010), criado pelo artista alemão Wolf Schreiber, apresenta exposições mensais otimizadas para visualização em telas de telefones celulares [imagem 42]. Já The Widget Art Gallery ${ }^{112}$, projeto desenvolvido pela artista italiana Chiara Passa, é uma minigaleria tridimensional com apenas uma sala, para caber na tela de um iPhone, iPod Touch ou iPad. Todo mês, uma exibição solo é escolhida para aparecer na galeria, enquanto todas as obras passadas ficam em um arquivo online [imagem 43].

109 BURNETTE, CHERRY, PROCTOR, SAMIS, 20II.

II0 MUSEUM APP. Disponivel em: < www.museumapp.nl>. Acesso em julho/2013.

III MOBILE ONLINE MUSEUM OF CONTEMPORARY ART. Disponivel em: < www.momca.de $>$. Acesso em junho/2013.

II2 THE WIDGET ART GALLERY. Disponivel em: < www.chiarapassa.it/TheWidgetArrGallery.html>. Acesso em julho/2013. 
Também não podemos esquecer os aplicativos de Realidade Aumentada, que transmitem ao vivo, a vista de um ambiente físico com elementos completares gerados por computador, tais como sons, vídeos, gráficos ou dados de GPS. A visão real é modificada digitalmente, com a intenção de aumentar a percepção da realidade. Informações artificiais são sobrepostas ao meio ambiente escolhido e enquadrado pela câmera do telefone. A visão computacional reconhece o mundo real e Ihe adiciona objetos informacionais que o tornam, digitalmente, manipulável e interativo ${ }^{113}$.

No MoMA, or artistas Mark Skwarek e Sander Veenhof realizaram uma 'invasão virtual' com a exibição em Augmented Reality chamada WeARinMoMA (2010). Fizeram com que todos que circulassem com um smartphone pela instituição pudessem ver obras tridimensionais feitas por eles flutuando entre suas galerias. $O$ museu polonês Sukiennice utilizou a programação em realidade aumentada em uma grande campanha de reabertura após passar por renovações. Um aplicativo chamado New Sukiennice trazia vida às pinturas do século XIX, com atores interpretando as histórias dos quadros da coleção. ${ }^{114}$

Segundo Lemos, os projetos de realidade aumentada permitem criar sentido por anotações no espaço público, colocando pessoas em contato permanente mesmo em um ambiente anônimo. Tentam criar, na superfície da cidade, uma zona de contato e acesso que fortalece as redes de sociabilidade e a apropriação do urbano. Essas são novas experiências de viver as metrópoles, "insistindo em formas de navegação por informações no interstício do espaço eletrônico e do espaço público das cidades contemporâneas" ${ }^{\prime 115}$.

O investimento na utilização dos dispositivos móveis e de telepresença, feito pelos museus e instituições artístico culturais, deve-se, principalmente, a sua característica de linha direta com o dia a dia do sujeito atual, constantemente conectado a essas

II3 WIKIPEDIA. Disponivel em: <

II4 REALIDADE AUMENTADA NA ARTE. 0 Globo online. Disponivel em: <www.oglobo.globo.com/infograficos/realidade-aumentada-arte>. Acesso jul/20l3.

IIS LEMOS, 2009, p. 58. 
tecnologias. Com a possibilidade de acessar o conteúdo dos museus em qualquer lugar, desde sua casa, trabalho ou ambiente de lazer, o espectador traz a vivência museológica para sua vida cotidiana, concretizando a antiga idealização de museu ubíquo.

Para o pesquisador de museologia Konstantinos Arvanitis, a relação do espectador com o museu através da mídia móvel modifica "a natureza ocasional da visita ao museu e transforma a informação e o conhecimento museológico em uma comodidade portátil, disponível em qualquer momento e em qualquer lugar". Arvanitis realça também, a importância da participação inversa, a vida cotidiana das pessoas entrando no museu:

"Ao acessar uma variedade de entendimentos que pertencem a efemeridade da vida cotidiana, ainda que escondendo mais profundos entendimentos e percepções da cultura material, museus devem melhorar o modo como eles interpretam a cultura material e prover experiências mais ricas para visitantes on-site e remotos. (...)

O cotidiano é um lugar de multiplicidade, onde a percepção das pessoas de seu redor toma a forma de conhecimento efêmero. As mídias móveis podem 'dar voz' à vida cotidiana e possibilitar os museus a se abrir à existência cotidiana que torna as pessoas quem elas são, como elas veem e compreendem o mundo a sua volta"116.

II6 ARVANITIS, Konstantinos. Museums outside walls: mobile phones and the museum in the everyday. In: Parry, Ross (ed.) Museums in a age digital. USA: Routledge, 2010, p. 172 e 175. [tradução livre] 


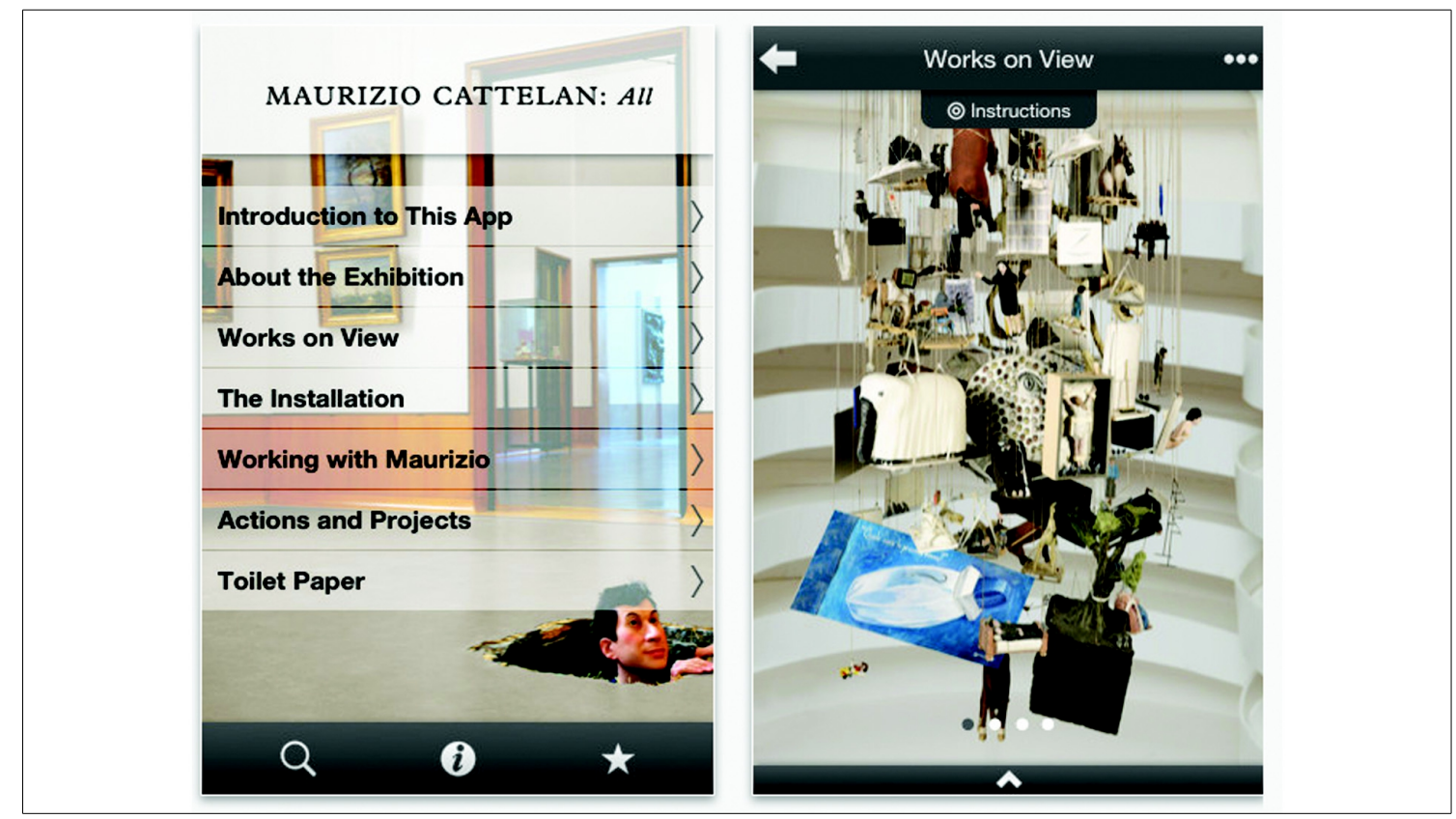

[imagem 38] MAURIZIO CATELLAN: ALL APP (Guggenheim).

Fonte:<www.papermaq.com/uploaded images/Screen $>$. Acesso em jul/2013.

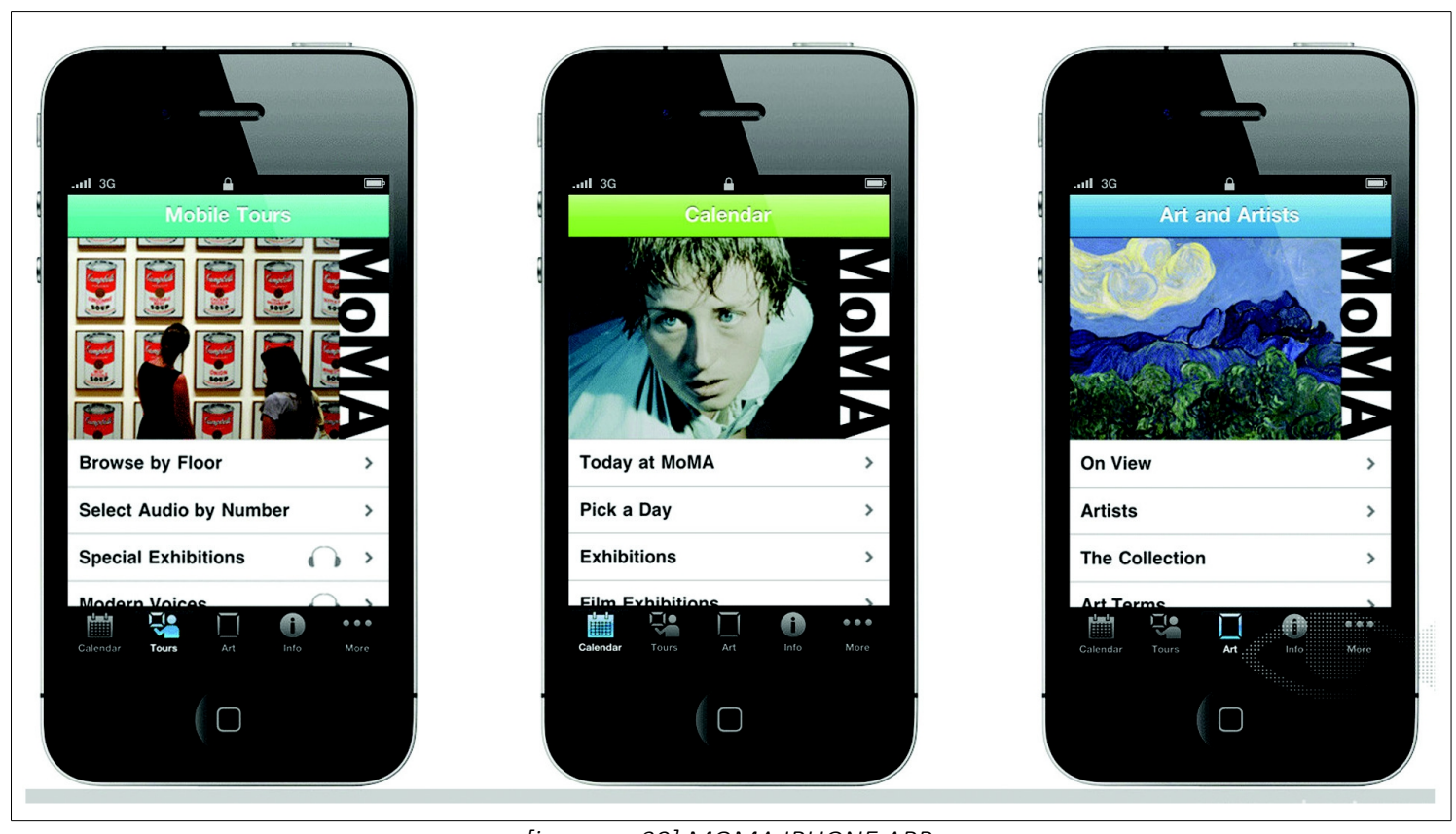

[imagem 39] MOMA IPHONE APP.

Fonte: <http://media.dexigner.com/article/20147/MoMA_iPhone_App.jpg>. Acesso em jul/2013. 


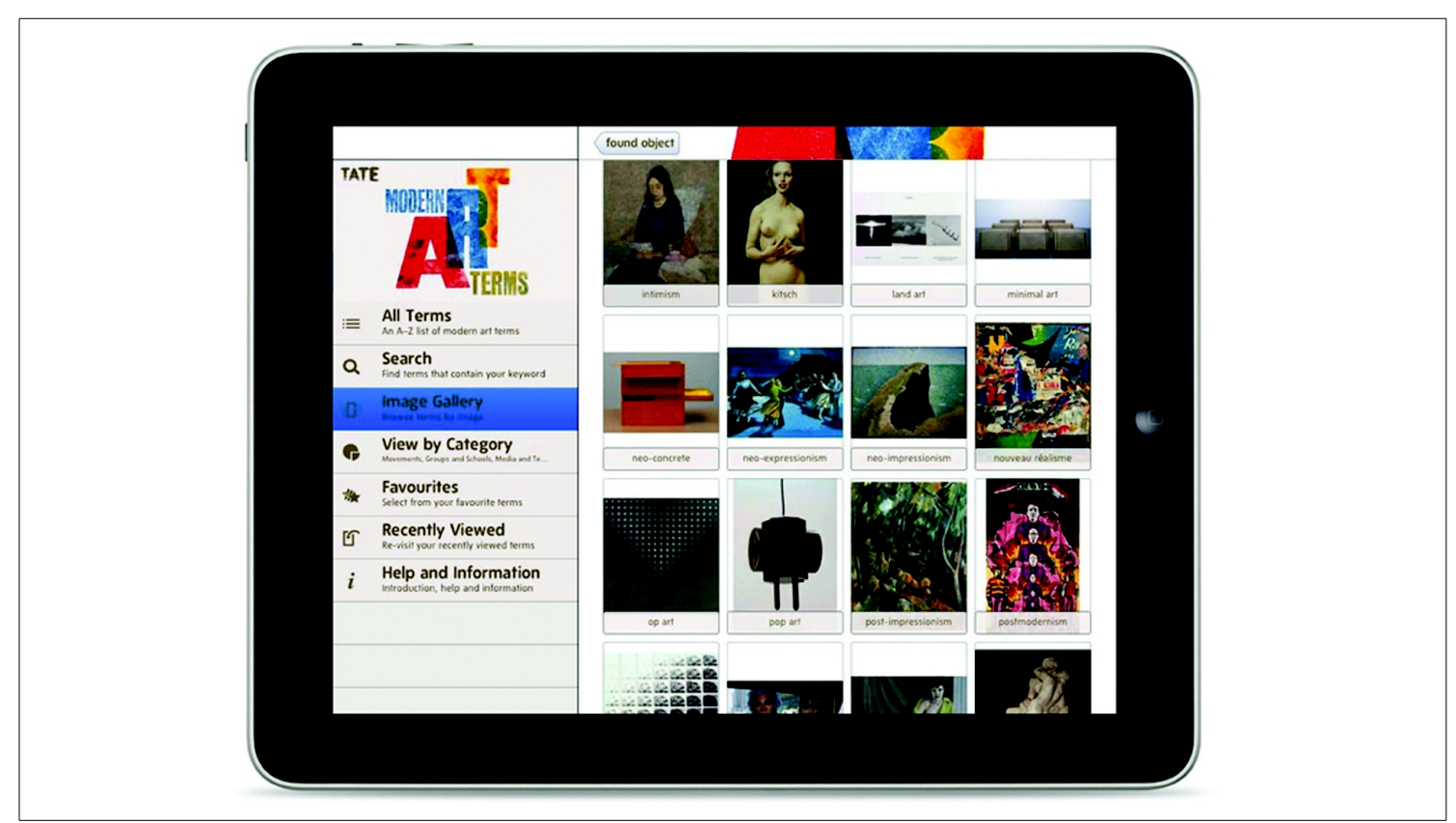

[imagem 40] TATE IPAD APP: Tate Guide to Modern Art Terms. Fonte: <http://ikono.org>. Acesso em jul/2013.

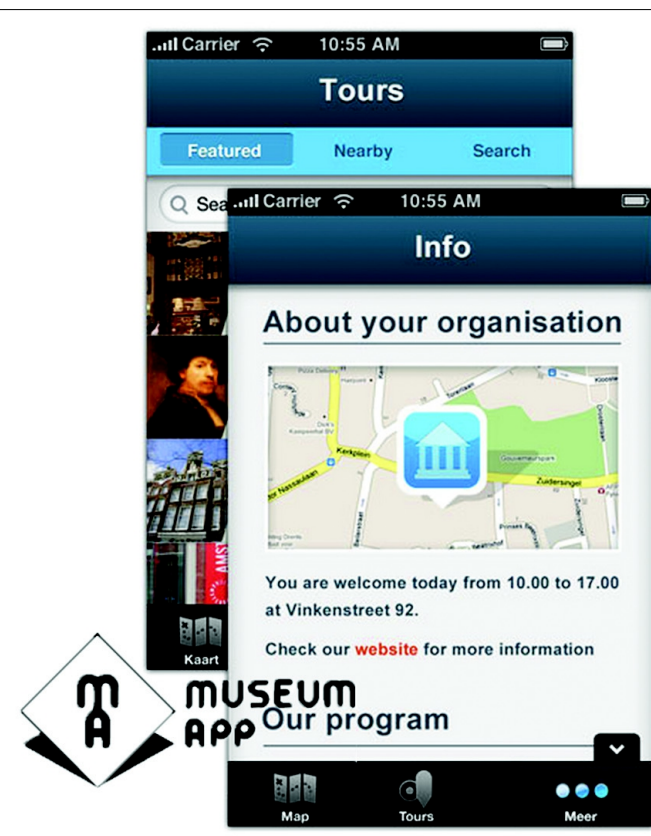

[imagem 41] Interface do MUSEUM APP.

Fonte: $\langle w w w$. museumapp.nl/mijn-eigen-museumapp.php $>$. Acesso em jul/2013. 


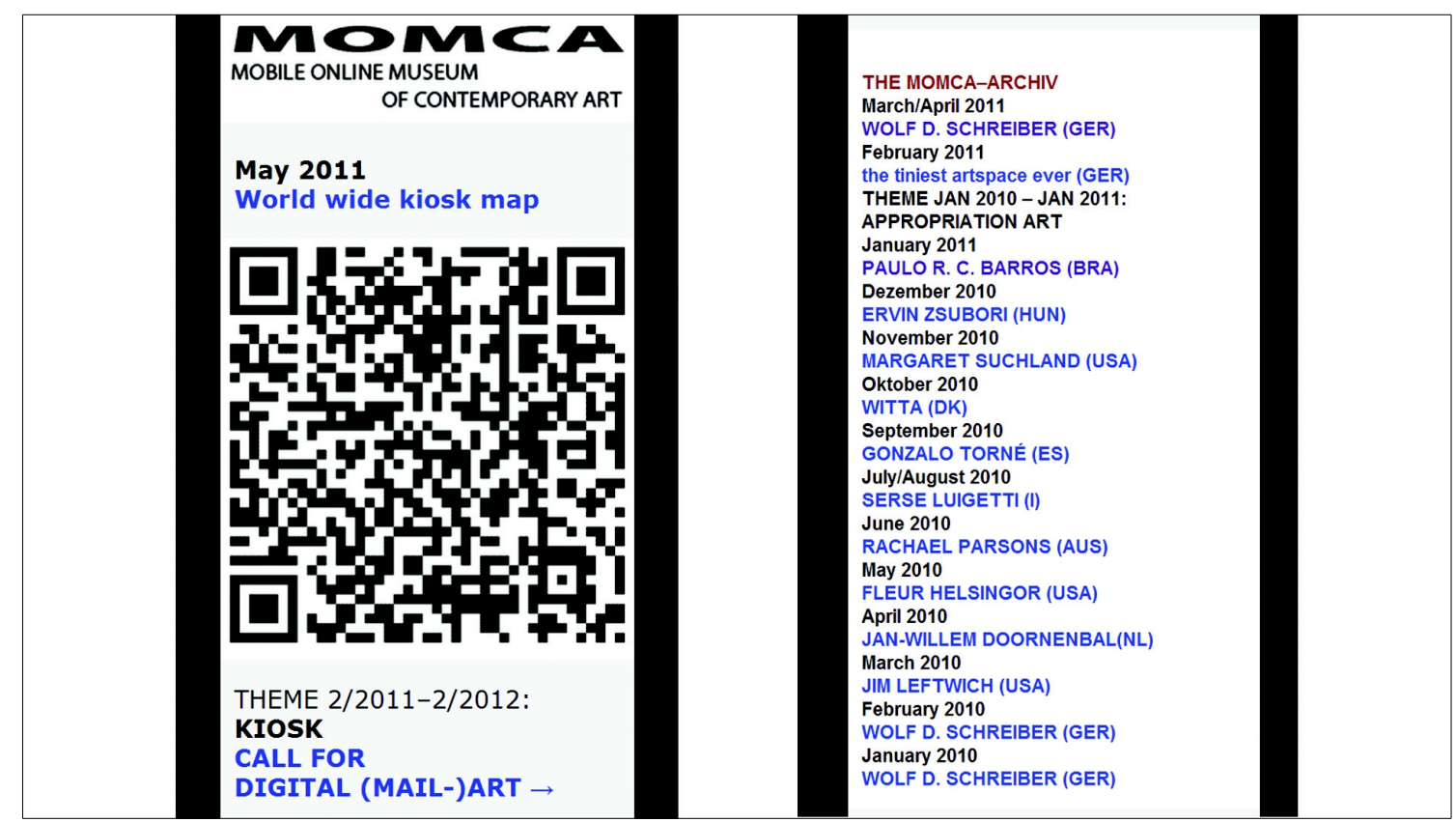

[imagem 42] MOBILE ONLINE MUSEUM OF CONTEMPORARY ART.

Fonte: $\langle$ www.momca.de $>$. Acesso em jul/2013.

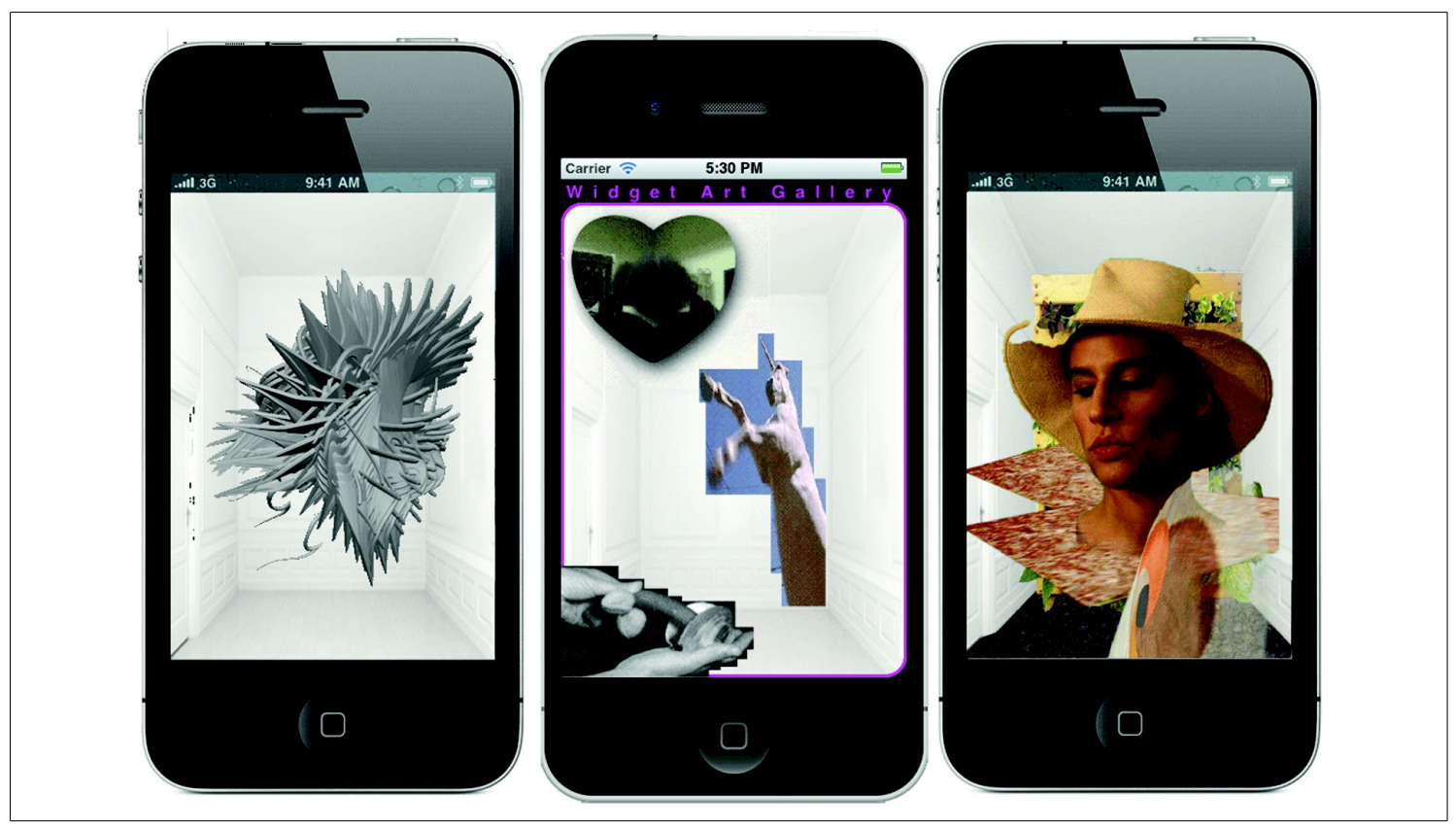

[imagem 43] THE WIDGET ART GALLERY.

Fontes: $\langle$ www.rhizome.org $\rangle\langle\underline{w w w . m e d i u m . c o m}\rangle\langle\underline{w w w . t u m b / r . c o m}\rangle$. Acesso em jul/2013. 
"As informações que hoje invadem nosso mundo são do tipo que nunca existiu antes: são informações imateriais. As imagens eletrônicas na tela da televisão, os dados armazenados no computador, os rolos de

filmes e microfilmes, hologramas e programas são tão 'impalpáveis' (software) que qualquer tentativa de agarrá-los com as mãos fracassa".

[Vilém Flusser, 1974] 


\section{DIRETRIZES PARA UM MUSEU VIRTUAL CONTEMPORÂNEO}

\section{I A WEB COMO ESPAÇO MUSEOGRÁFICO DA ARTE EFÊMERA, DA PERSONALIZAÇÃO E DO COLECIONISMO}

Ao observarmos de perto a forma como os museus adentraram a internet ao longo dos anos, podemos perceber que as práticas culturais na rede acompanharam sua evolução. A web passou a ser um lugar aberto a manifestações artísticas individuais, ao consumo de informação digitalizada e a socialização de preferências culturais. Seguindo esses passos, os formatos museográficos na internet hoje, realçam as capacidades de preservação de ações de arte efêmera, de divulgação de projetos artísticos pessoais, e de coleção e compartilhamento de conteúdos diversos entre amigos e desconhecidos.

A reprodução e documentação digital tornou possível que obras de arte de curta vida útil ou que desapareceram de alguma forma (má conservação ou roubo, por exemplo) pudessem ser expostas em forma de coleções virtuais. A Tate Gallery de Londres criou em seu website uma mostra chamada Gallery of Lost Art, ou em português: 'Galeria da Arte Perdida ${ }^{117}$. Ela expôs histórias de obras de arte do século XX que desapareceram. Obras que foram destruídas, descartadas ou apagadas. Eram fotografias, matérias de jornal, recortes, cartas e filmes, que revelavam as características de obras perdidas de mais de quarenta artistas. A galeria ficou online de julho de 2012 a julho de 2013, e por fim, seguindo a ocasionalidade do assunto tratado, também foi deletada [imagem 44].

II7 THE GALLERY OF LOST ART. Disponivel em: < http://galleryoflostart.com>. Acesso em julho/2013. 
Um vasto repositório de obras de artistas que já não podem ser facilmente encontradas, é o site $U$ buweb ${ }^{118}$. A página iniciou suas atividades na internet em 1996 como um depósito de poesia visual, concreta e sonora. Com o tempo, começou a abarcar outras formas de manifestações artísticas e continua ampliando seus parâmetros. Hoje, apresenta um catálogo com vídeos, sons e textos, além de artigos sobre áudio, performance, arte conceitual, entre outros assuntos. O site se define como um centro de distribuição de materiais difíceis de serem encontrados, fora de catálogo ou pouco conhecidos, transferidos para web. Segundo a própria página, um arquivo de "detritos de grandes artistas", "efemeridades", ou "periferias da produção artística" [imagem 45].

Uma das mais importantes conquistas do meio artístico, com o uso da internet, foi a apropriação do ciberespaço por artistas individuais, como canal de divulgação e exposição para suas obras. O caminho mais comum seria o artista desenvolver uma relação com o dono de uma galeria, que exibe seus trabalhos até conseguir a atenção do curador de um museu. Mas a web conseguiu, no mundo artístico e em muitas outras áreas, cortar o intermediário ${ }^{119}$. O artista de hoje consegue chamar a atenção de curadores sem passar, obrigatoriamente, pela galeria. No primeiro capítulo, foi citado o vídeo Luminare, exemplo de um dos primeiros passeios por galerias digitais criado. O vídeo pode ser encontrado no canal particular do YouTube do artista Dean Winkler, no qual ele pode expor seus trabalhos de videoarte realizados entre 1976 e 1991 [imagem 46].

Desde o início da internet, antes dos profissionais das artes começarem a divulgar seus trabalhos através de redes sociais, já eram criadas páginas de artistas e disponibilizadas na rede, coleções pessoais. Pessoas comuns, sozinhas ou em grupos, começaram a criar exposições e coleções na web, sobre qualquer assunto de seu interesse, mas especialmente, para apresentar trabalhos artísticos. Ainda em 1994,

118 UBUWEB. Disponivel em: $<$ www.ubuweb.com $>$. Acesso em jul/2013.

II9 MILLER, Claire Cain. Social Media as Inspiration and Canvas. The New York Times online, 16 mar. 2011. Disponivel em: < http://www.nytimes.com/2011/03//7/arts/design/flickr-photos-and-vimeo-videos-as-artwork.html>. Acesso em maio/2013. 
utilizando o navegador Mosaic, a artista de Cingapura Lin Hsin Hsin criou um museu pessoal para expor suas obras. O Lin Hsin Hsin Art Museum ${ }^{120}$ funciona até hoje com espaços para seus projetos em pintura, escultura, cerâmica, desenho, poesia e arte digital. Através de trabalhos digitais, ela brinca com a ideia de um teatro, um toalete e uma loja dentro de seu museu [imagem 47].

O processo de colecionismo também foi incentivado pela rede mundial de computadores. Com o fácil acesso a informações pela internet, as pessoas passaram a compilar assuntos de sua preferência e publicá-los em websites, formando coleções de curadoria própria. A trama da internet permite que uma série de links formem um catálogo gigantesco sobre algum tema específico, com conteúdo de qualquer parte do mundo.

No site One Hundred Boxes ${ }^{121}$ (2009), Nicolas Koch e Stefan Riebel começaram a relacionar "espaços artísticos obscuros". Na página podemos encontrar cerca de 25 links sobre espaços para exposição de arte diferentes do padrão. Nem todos funcionam apenas online e a maioria parte de algum tipo de proposta artística, de uma ou mais pessoas [imagem 48]. Ali, encontram-se abordagens interessantes das novas tecnologias como espaço museográfico. No projeto do Mini Museum of XXI Century $\operatorname{Arts}^{122}$ (2010), um museu foi fundado dentro de um porta-retratos digital de 7 polegadas. O pequeno museu passeia por uma rede de artistas que o utilizam para expor os seus trabalhos enquanto estão com ele. Cada exposição fica armazenada na memória interna do aparelho [imagem 49]. Já a 700MB Gallery ${ }^{123}$ (2009) apresenta mensalmente uma mostra de um artista novo em sua página. Os trabalhos devem ser enviados à galeria, exclusivamente, em CDs de 700 megabytes. Exibições antigas também são disponibilizadas no site [imagem 50].

I20 LIN HSIN HSIN ART MUSEUM. Disponivel em: <www.lhham.com.sg >. Acesso em jun/2013.

I2I ONE HUNDRED BOXES. Disponivel em: < www.onehundredboxes.com>. Acesso em jul/2013.

I22 THE MINI MUSEUM OF XXI CENTURY ARTS. Disponivel em: <http://minimuseum.linkartcenter.eu >. Acesso em jul/20I3.

I23 700MB GALLERY. Disponivel em: <www.700mbg.com>. Acesso em jul/2013. 
Por fim, ainda há uma compilação importante de ser lembrada. O estúdio de design e publicidade americano Coudal Partners criou em uma parte de seu site o Museum of Online Museums ${ }^{124}$ [imagem 51]. A página do 'museu dos museus online' apresenta links para arquivos, coleções e exposições online de diversos interesses, desde arte e arquitetura clássica até obsessões por objetos, que por sua quantidade e classificação, podem adquirir a posição de coleção artística. O museu possui três sessões: Campus do Museu, links para páginas online de grandes museus com sede física; Coleção Permanente, com links para mostras sobre design e publicidade especificamente; e Galerias, Exposições e Mostras, uma lista eclética e em constante mudança de coleções de assuntos específicos, geralmente postadas por pessoas comuns. A página acaba sendo uma grande fonte de referências para os profissionais de criação do estúdio. Alguns dos links disponibilizados são, por exemplo, para o Bauhaus Archive ${ }^{125}$, para o American Museum of Photography ${ }^{126}$, ou The Archive of Lost Films ${ }^{127}$.

I24 THE MUSEUM OF ONLINE MUSEUMS. Disponivel em: <www.coudal.com/moom >. Acesso em jun/2013.

I25 BAUHAUS ARCHIVE. Disponivel em: <www.bauhaus.de>. Acesso em jul/2013.

I26 AMERICAN PHOTOGRAPHY MUSEUM. Disponivel em: <www.photographymuseum.com >. Acessso em jul/2013.

127 THE ARCHIVE OF LOST FILMS. Disponivel em: <www.lost-films.eu>. Acesso em jul/2013. 


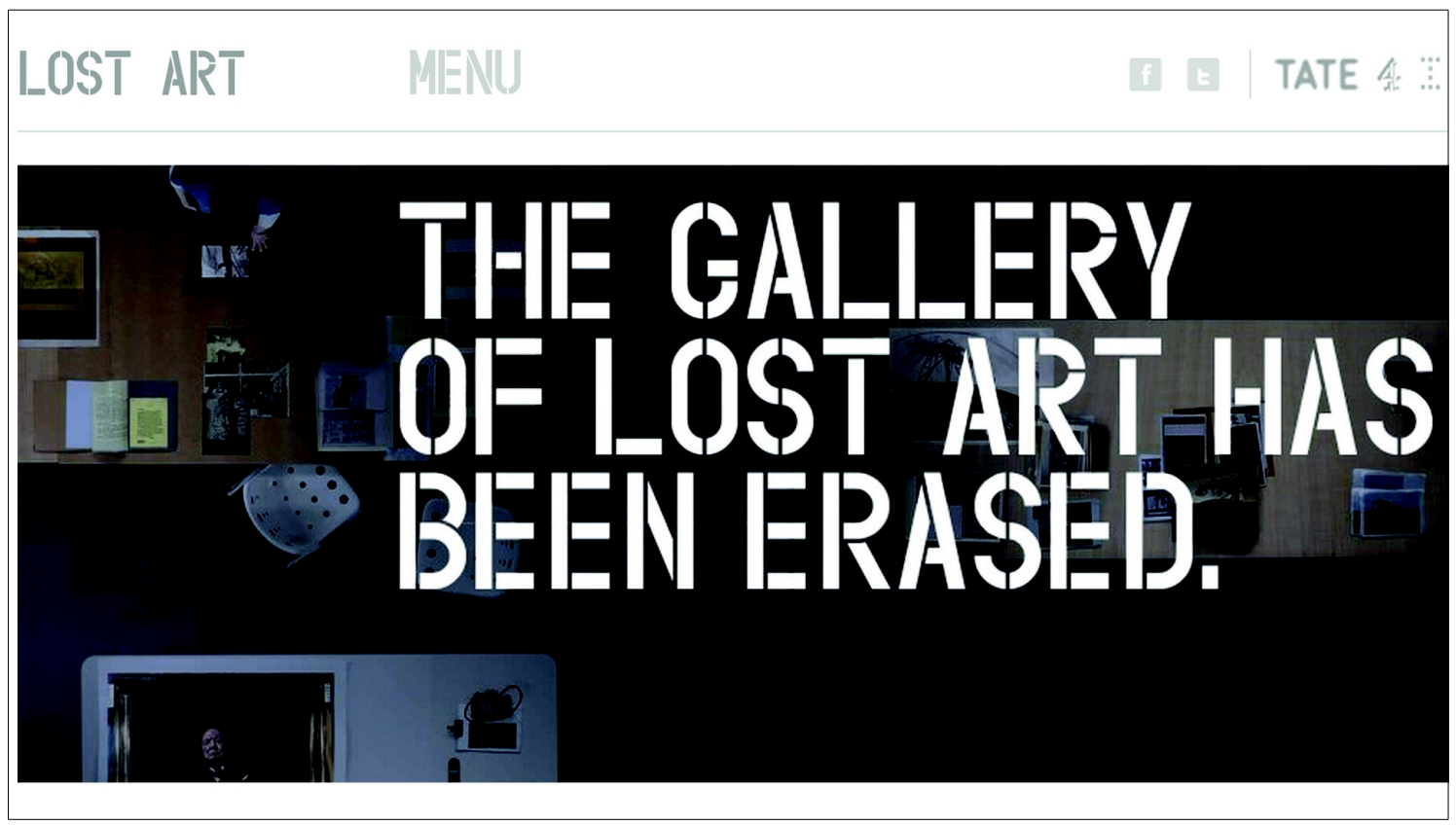

[imagem 44] Página da GALLERY OF LOST ART (Tate Gallery).

Fonte: <http://galleryoflostart.com>. Acesso em jul/2013.

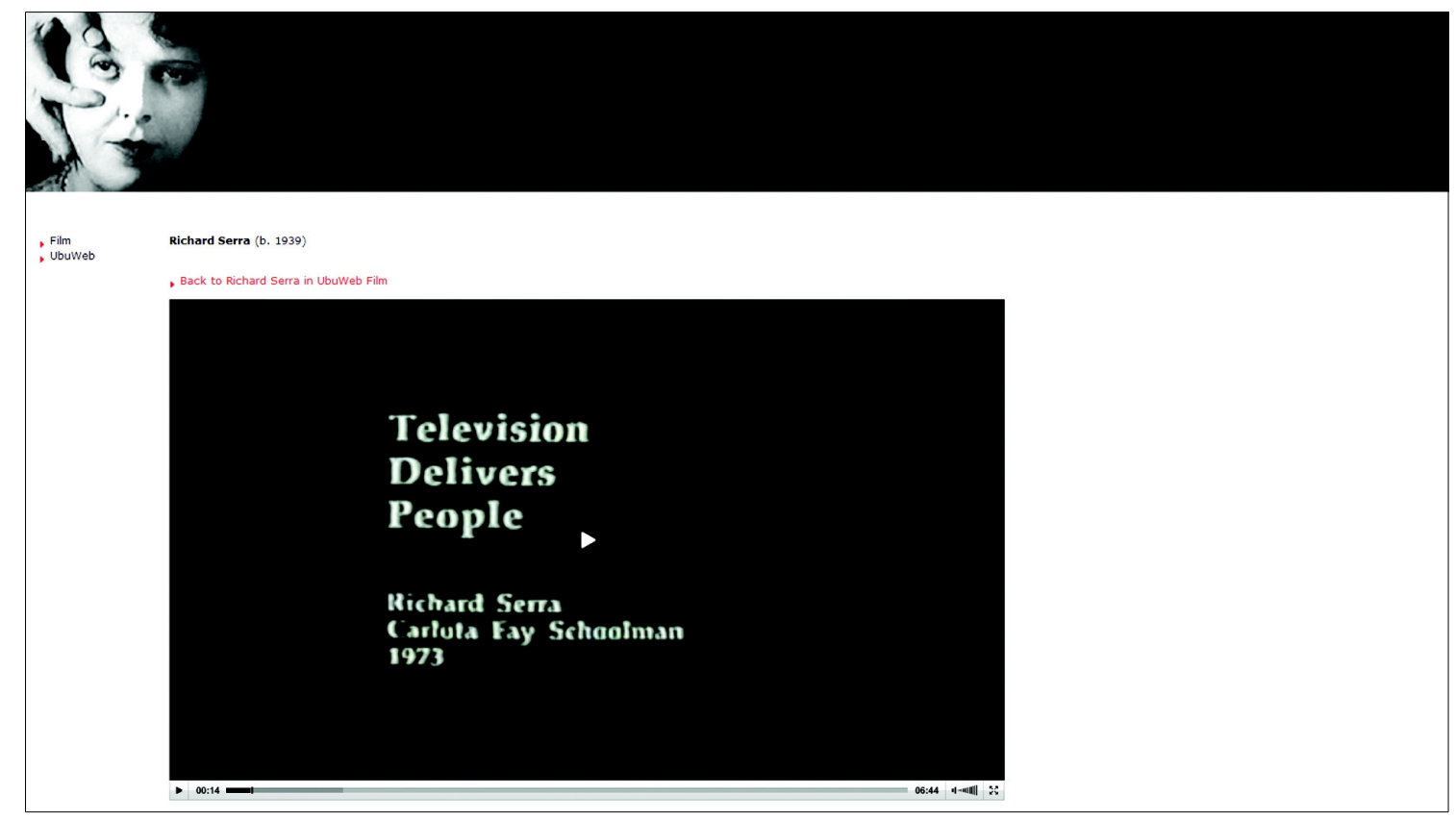

[imagem 45] Vídeo de Richard Serra: Television Delivers People (1973) no UBUWEB. Fonte: $\langle w w w . u b u w e b . c o m>$. Acesso em jul/2013. 

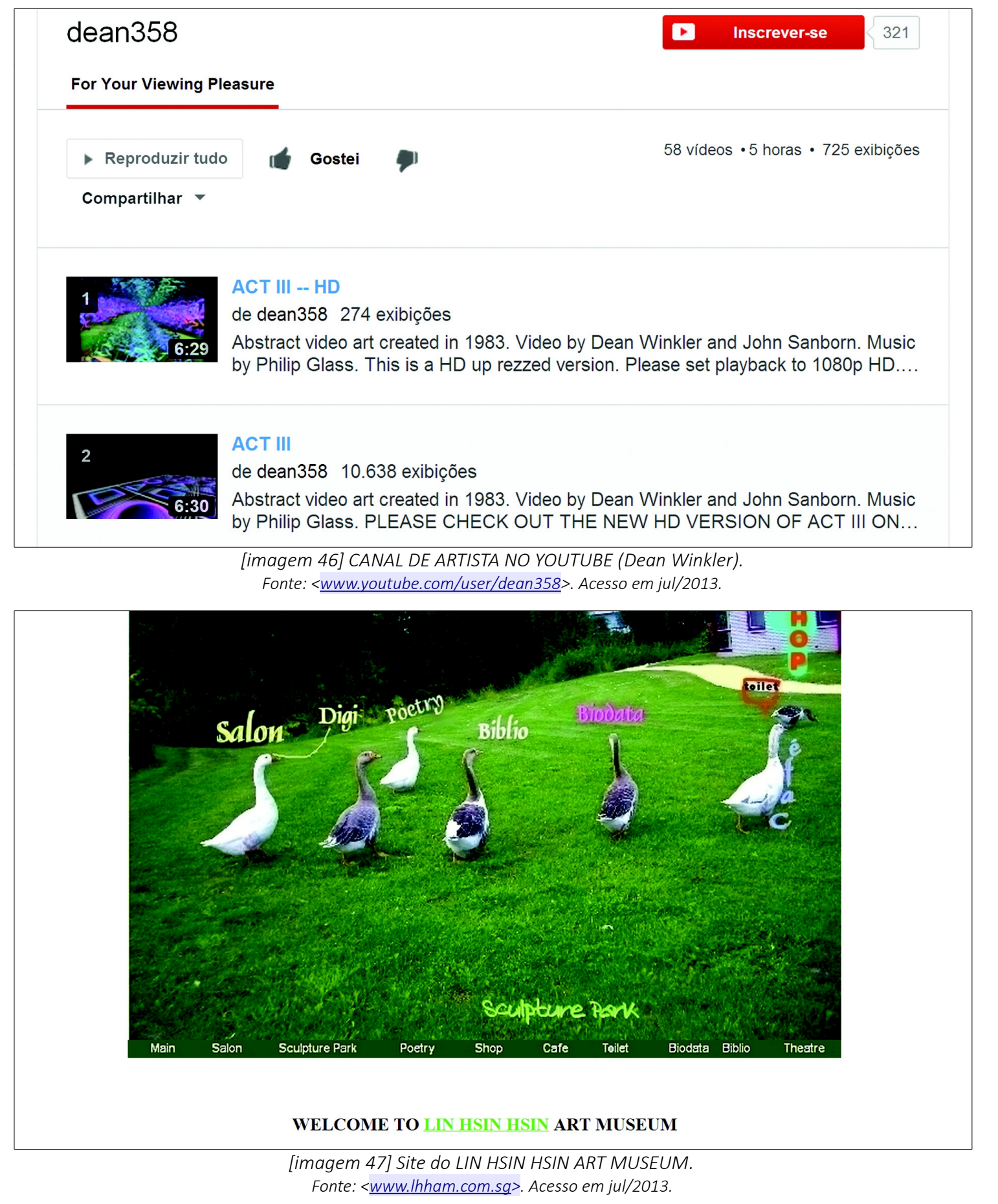


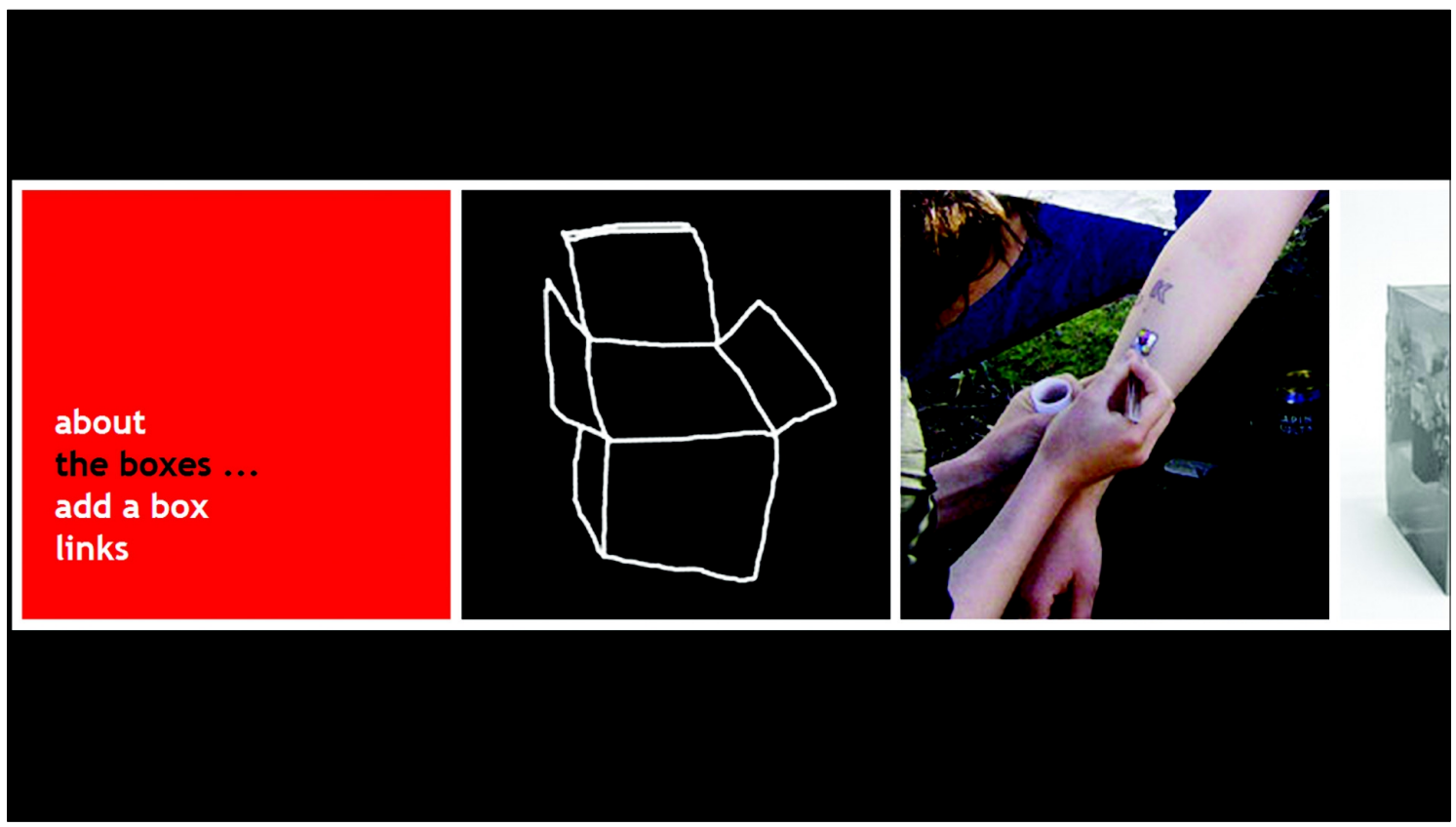

[imagem 48] Projeto ONE HUNDRED BOXES.

Fonte: <www.onehundredboxes.com>. Acesso em jul/2013.

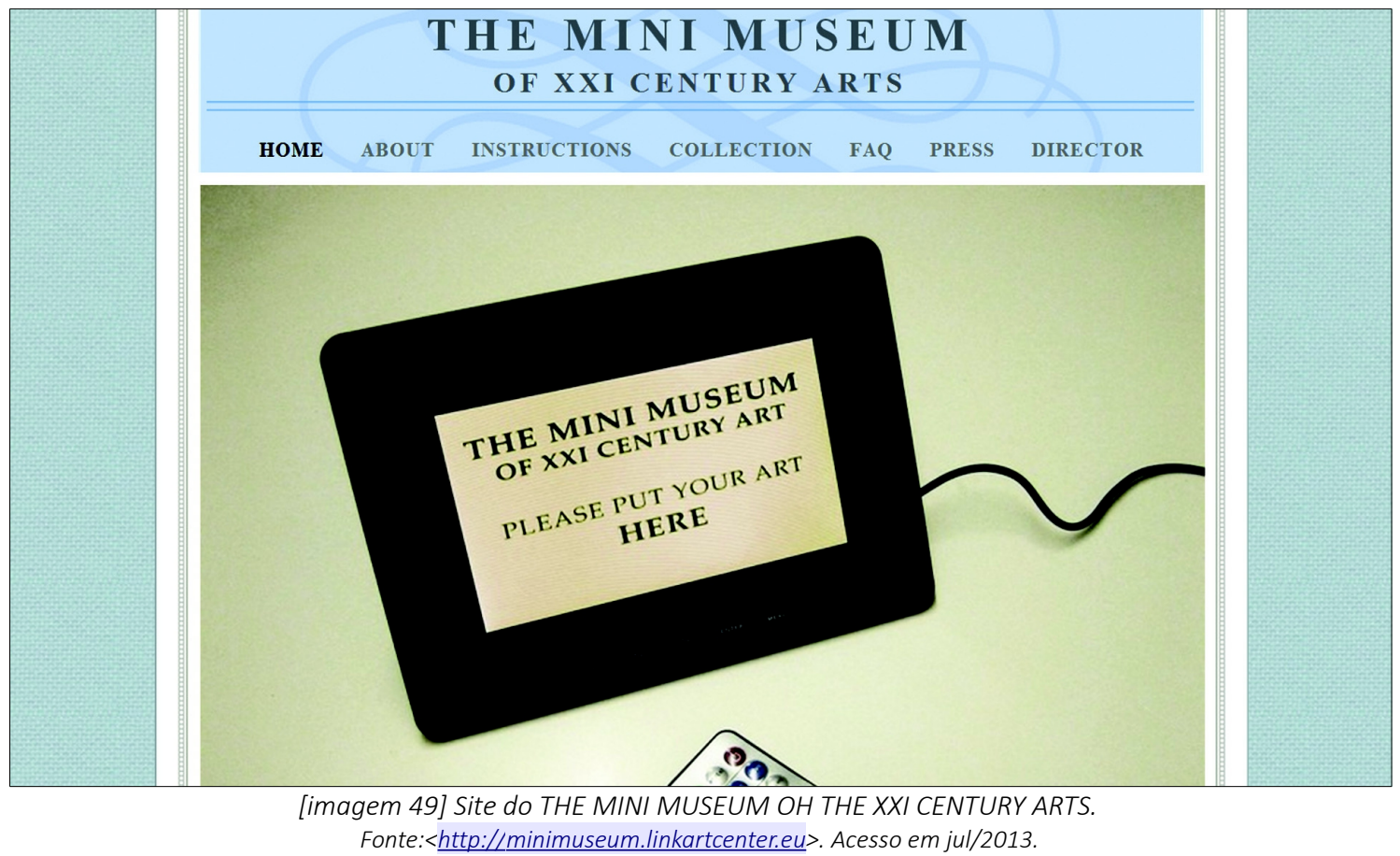




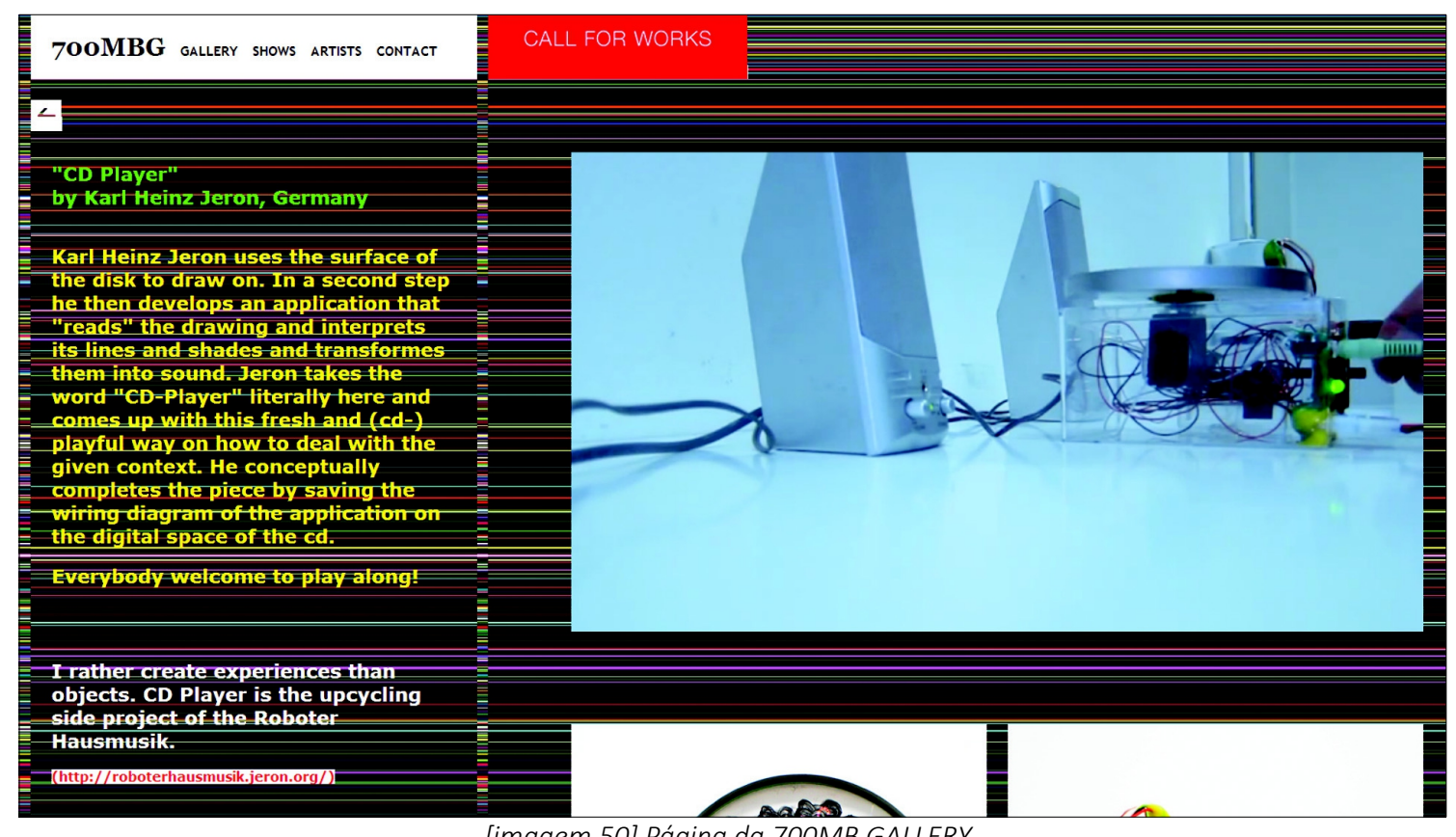

[imagem 50] Página da 700MB GALLERY.

Fonte: $<w w w .700 \mathrm{mbq} . \mathrm{com}>$. Acesso em jul/2013.

Can you really clean your computer keyboard in the dishwasher? Michele finds out in Shift Option Rinse.

COUDAL PARTNERS About This Site

NOW SHOWING

III Exceptional exhibits are highlighted each quarter. Selections from previous

seasons are archived here.

\section{THE BOARD}

Please consider joining our MoOM Board of Directors won't you? You'll receive some nice swag and can lord it over your less civic-minded friends.

FALL 2012

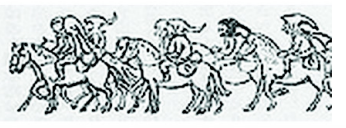

THE MUSEUM OF ONLINE MUSEUMS

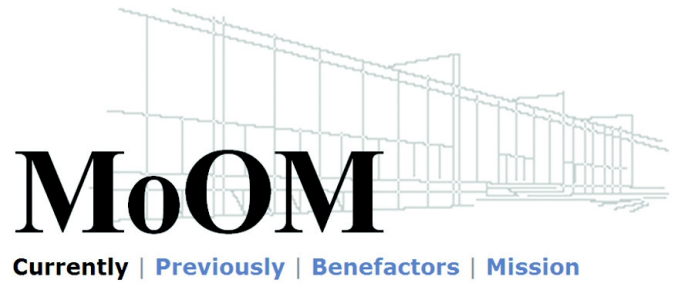

Welcome to the MoOM. The galleries are updated

continuously, and new exhibitions are hung each quarter.

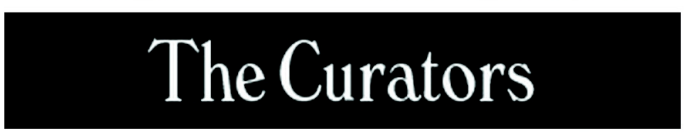

Introducing a film from Coudal Partners and The Board of

[imagem 51] Projeto THE MUSEUM OF ONLINE MUSEUMS.

Fonte: $<$ www.coudal.com/moom $>$. Acesso em jul/2013. 


\subsection{PROJETO EXPERIMENTAL: MUSEU VIRTUAL DA INTERVENÇÃO URBANA EM SÃO PAULO}

\subsection{REDES SOCIAIS COMO PLATAFORMA PARA O COLECIONISMO E PERSONALIZAÇÃO}

A web e a conexão móvel catalizaram o que se tornou o maior fenômeno da internet até o momento: as redes sociais. Grupos e círculos sociais já existiam há muitos anos, o que mudou agora foi a abrangência no espaço e a quantidade de seus participantes. Para a maioria dos jovens, usuários de sites como o Facebook, Twitter ou YouTube, as redes sociais substituem e-mail, blogs, chats, e álbuns de fotos e $v^{\text {vídeos }}{ }^{128}$. Elas revolucionaram a forma das pessoas se relacionarem ao incorporar as interações sociais à experiência de navegação online ${ }^{129}$. As mídias sociais geram valores através da comunicação e criatividade coletivas da audiência, e sua cultura apresenta motivações comerciais e comunitárias. Elas são grandes o suficiente para serem consideradas um importante mecanismo de mediação com a esfera cultural pública ${ }^{130}$. Castells vê um novo sistema de comunicação sendo organizado em nossas sociedades: "todos os meios de comunicação podem ser conectados através da internet; o que contribui para a socialização da comunicação"131.

As possibilidades tecnológicas atuais permitem que as informações postadas por todos sejam facilmente encontradas no local e momento certos ${ }^{132}$. No entanto, com a multiplicação exponencial da quantidade de conteúdo na web, as pessoas sentiram a necessidade de criar formas de guardar as informações que consideravam mais interessantes para usá-las e compartilhá-las dentro de diferentes contextos.

I28 GABRIEL, 2009, p. 67.

I29 SABBAGH, ACKER, KARAM, RAHBANI, 2011.

I30 HARTLEY, 2009, p. 105.

131 CASTELLS, 2010, p. 428. [tradução livre]

132 GABRIEL, 2009, p. 67. 
O surgimento de sites que possibilitam ao usuário a criação de conjuntos de referências próprias foi o primeiro passo para os movimentos de colecionismo através da internet. Guardar links considerados, pessoalmente importantes ou relevantes, passou a ser um hábito tão natural quanto acessar as redes sociais para postar fotos de festas e conversar com amigos. Aliás, os históricos online, de um perfil em qualquer rede social, já se tornaram grandes arquivos da história da vida das pessoas (pelo menos a história recente).

Em maio de 2011, a empresa de tecnologia Intel criou uma campanha publicitária interativa chamada The Museum of $\mathrm{Me}^{133}$. Ao acessar a página do museu, os visitantes se deparavam com um museu virtual deles mesmos. Utilizando o perfil do Facebook do usuário, a interface criava um conjunto de galerias virtuais com fotos de amigos, fotos pessoais, frases comumente utilizadas, localização geográfica e 'curtidas'. A exposição podia ser compartilhada com os amigos no mural do prórprio Facebook [imagem 52].

Também em 2011, uma dupla de publicitários de São Paulo criou o perfil Instagrafite ${ }^{134}$ na rede social de compartilhamento de fotografias Instagram. A ideia é que qualquer pessoa do mundo pode participar do processo curatorial postando fotos com o nome do perfil, que depois passam por uma seleção. Hoje, eles já possuem mais de 650 mil seguidores e 2 mil e trezentas postagens e se apresentam como a maior galeria colaborativa de arte urbana do mundo [imagem 53].

Galerias ainda mais pessoais são as criadas por indivíduos comuns para expor seus próprios trabalhos na internet de forma independente. Redes sociais como Behance, DeviantArt e ArtWorkProject, além dos mais populares Flickr e Vimeo ${ }^{135}$, para citar alguns exemplos, são amplamente usadas por fotógrafos, designers, artistas visuais,

133 THE MUSEUM OF ME. Disponivel em: <www.intel.com/museumofme> Acesso em julho/201I.

I34 INSTAGRAFITE. Disponivel em: < http://instagram.com/instagrafite>. Acesso em julho/2013.

I35 BEHANCE é uma plataforma para a criação de portfólios online e uma rede social para profissionais da indústria criativa <behance.net>. DEVIANTART é uma comunidade online para a divulgação de trabalhos artísticos de seus usuários < deviantart.com>. ARTWORKPROJECT é um espaço aberto para a criação de portfólios online de expressões artisticas e contato com uma comunidade de criativos <artworkproject.com>. FLICKR é um site da web de hospedagem e partilha de imagens fotográficas <flickr.com>. VIME0 é um portal de compartilhamento de vídeos no qual os usuários podem subir, compartilhar e assistir vídeos < vimeo.com>. Fonte: WIKIPEDIA. Acesso em jul/20I3. 
videomakers e não-profissionais, como galerias para seus portfólios virtuais. Além de publicar seus próprios trabalhos, os usuários das redes ainda podem se conectar a outros artistas ou empresas para criar parcerias e colaborações [imagens 54].

Uma das redes sociais mais utilizadas atualmente para separar referências e colecionar imagens é o website Pinterest ${ }^{136}$. Criado em março de 2010, o Pinterest é um site de compartilhamento de fotos em estilo 'quadro de anotações', que permite aos usuários criar e gerenciar coleções de imagens com base em temas escolhidos. Figuras encontradas na web são 'espetadas no mural' da conta pessoal de cada usuário. Essas imagens são compartilhadas e podem ser 'espetadas' por outros participantes da rede em seus murais. Muitos museus e galerias utilizam essa rede social para divulgar suas coleções e recolher imagens de seu local postadas por outros. A página do SFMOMA ${ }^{137}$ na rede social possui 690 imagens e 22 painéis de temas como Artist as a Muse, Exhibitions, MuseumStore, entre outros [imagem 55].

Outra página importante para se colecionar, além de imagens, também weblinks, textos, vídeos e variados tipos de arquivo é a rede social Delicious. O site, fundado em 2003 e anteriormente chamado del.icio.us, é uma rede social que promove serviços de 'marcação' de assuntos na web. Através da página, as pessoas podem publicar e marcar textos, fotos, weblinks e outros tipos de arquivos em seu perfil para guardarem materiais de seu interesse e também divulgá-los entre amigos [imagem 56].

As duas últimas redes sociais citadas, Pinterest e Delicious, serão utilizadas em um projeto experimental para a criação de um Museu Virtual da Intervenção Urbana em São Paulo, descrito a seguir.

I36 PINTEREST. Disponivel em: < http://pinterest.com >. Acesso em jul/2013.

I37 Perfil do SFMOMA na rede social Pinterest. Disponivel em: <http://pinterest.com/sfmoma $>$. Acesso em jul/20I3. 


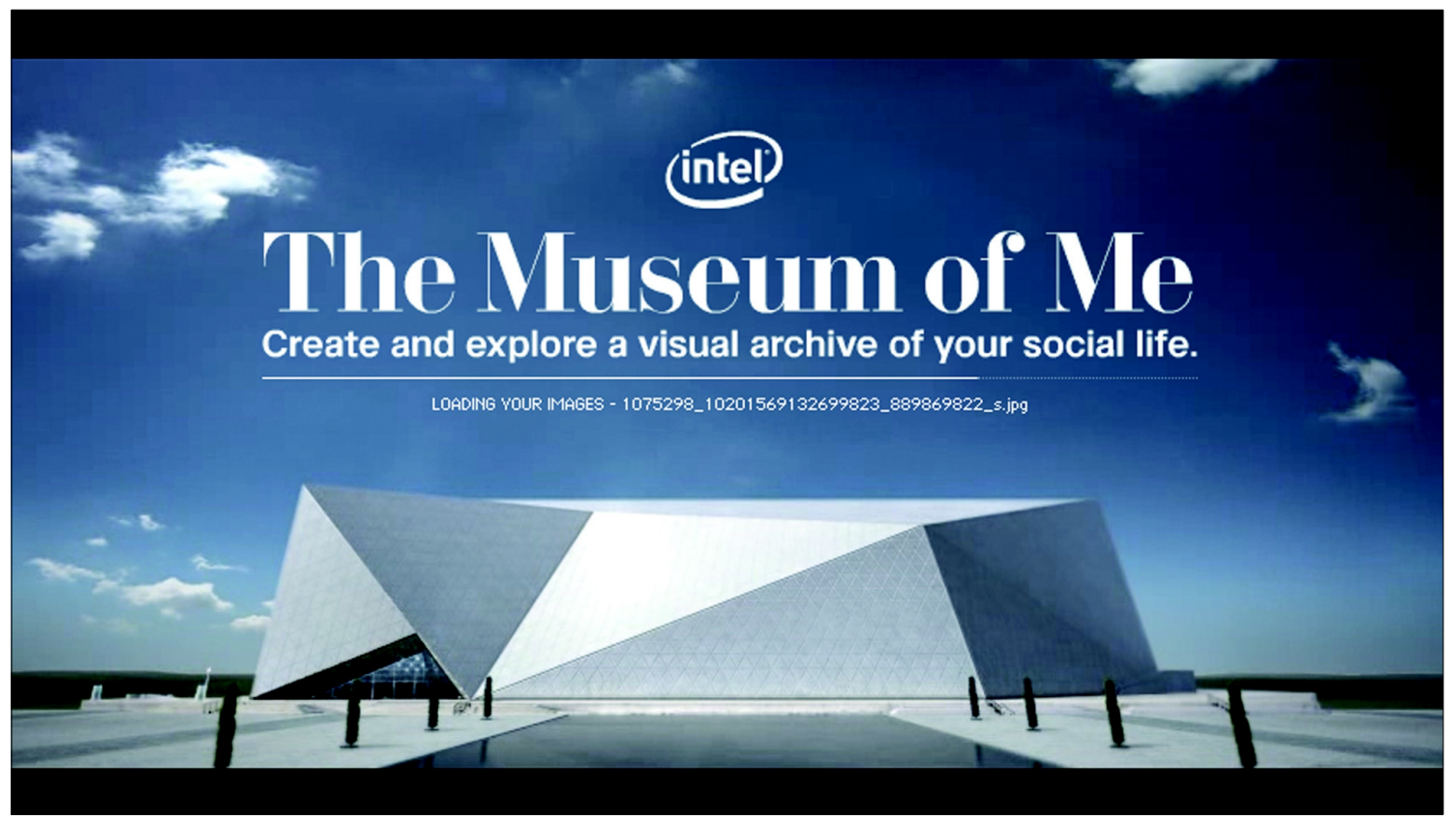

[imagem 52] Site do projeto da Intel: THE MUSEUM OF ME..

Fonte: $<w w w . i n t e l . c o m / m u s e u m o f m e>$. Acesso em julho/2013.

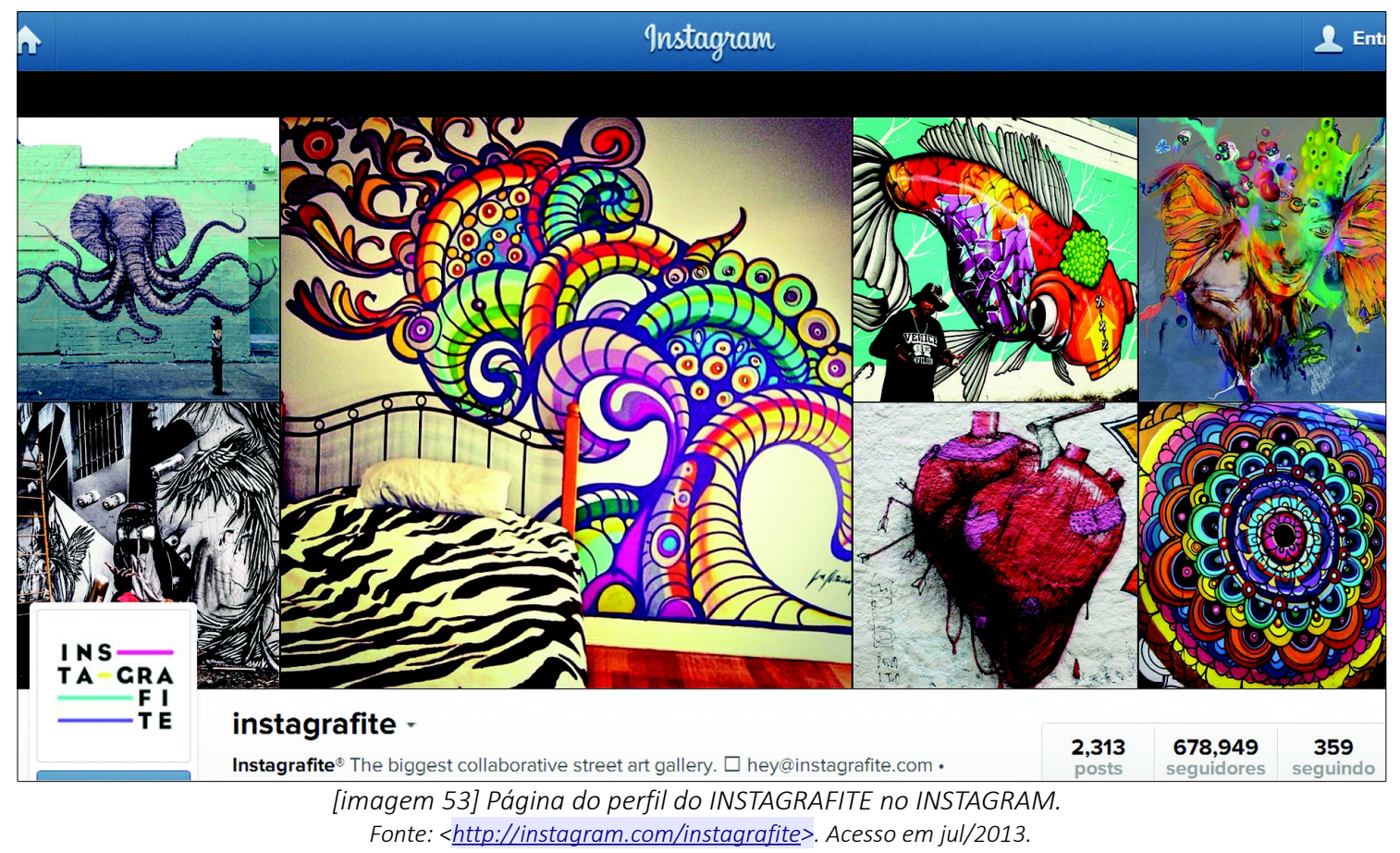




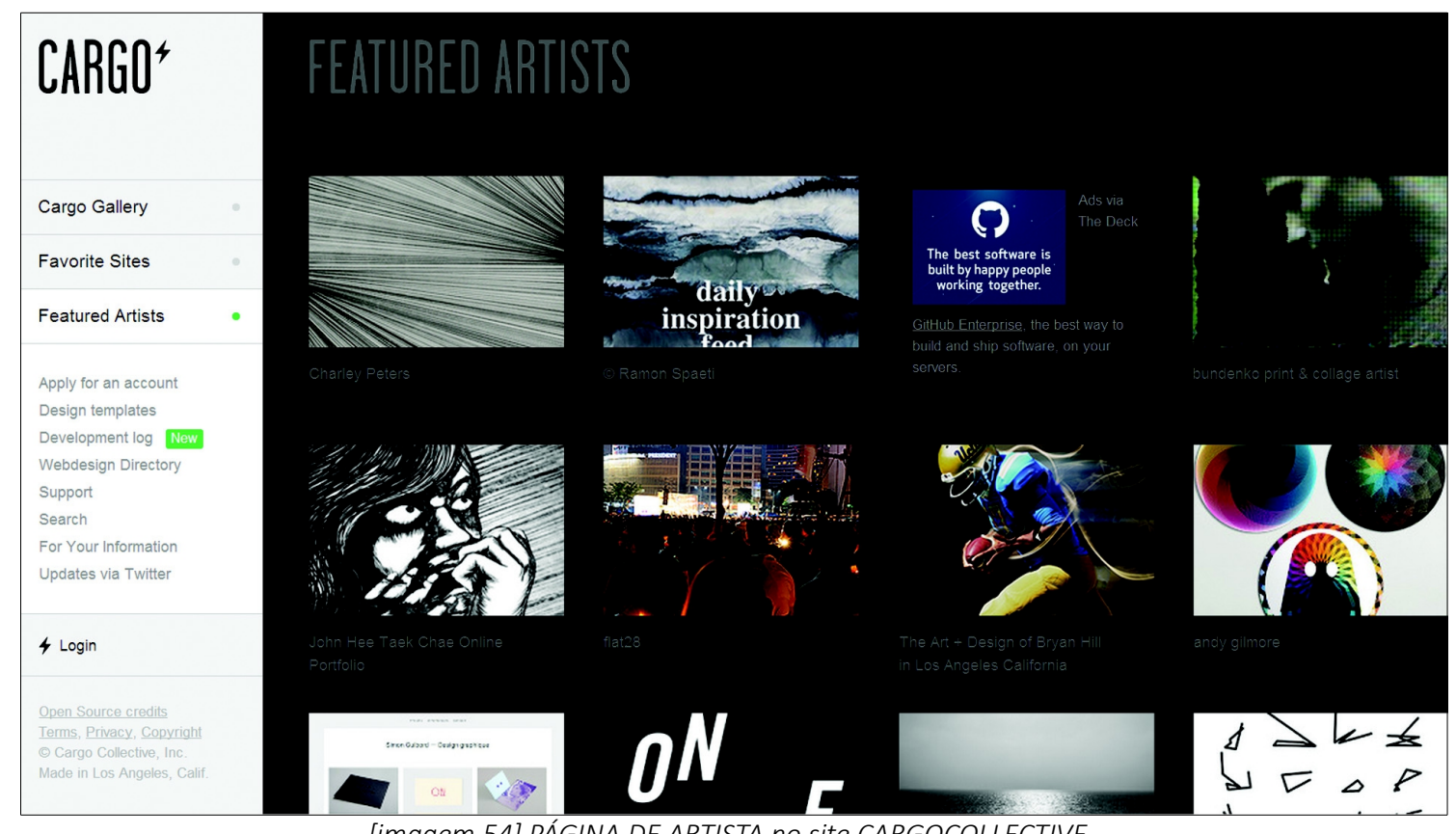

[imagem 54] PÁGINA DE ARTISTA no site CARGOCOLLECTIVE. Fonte: <http://cargocollective.com>. Acesso em jul/2013.

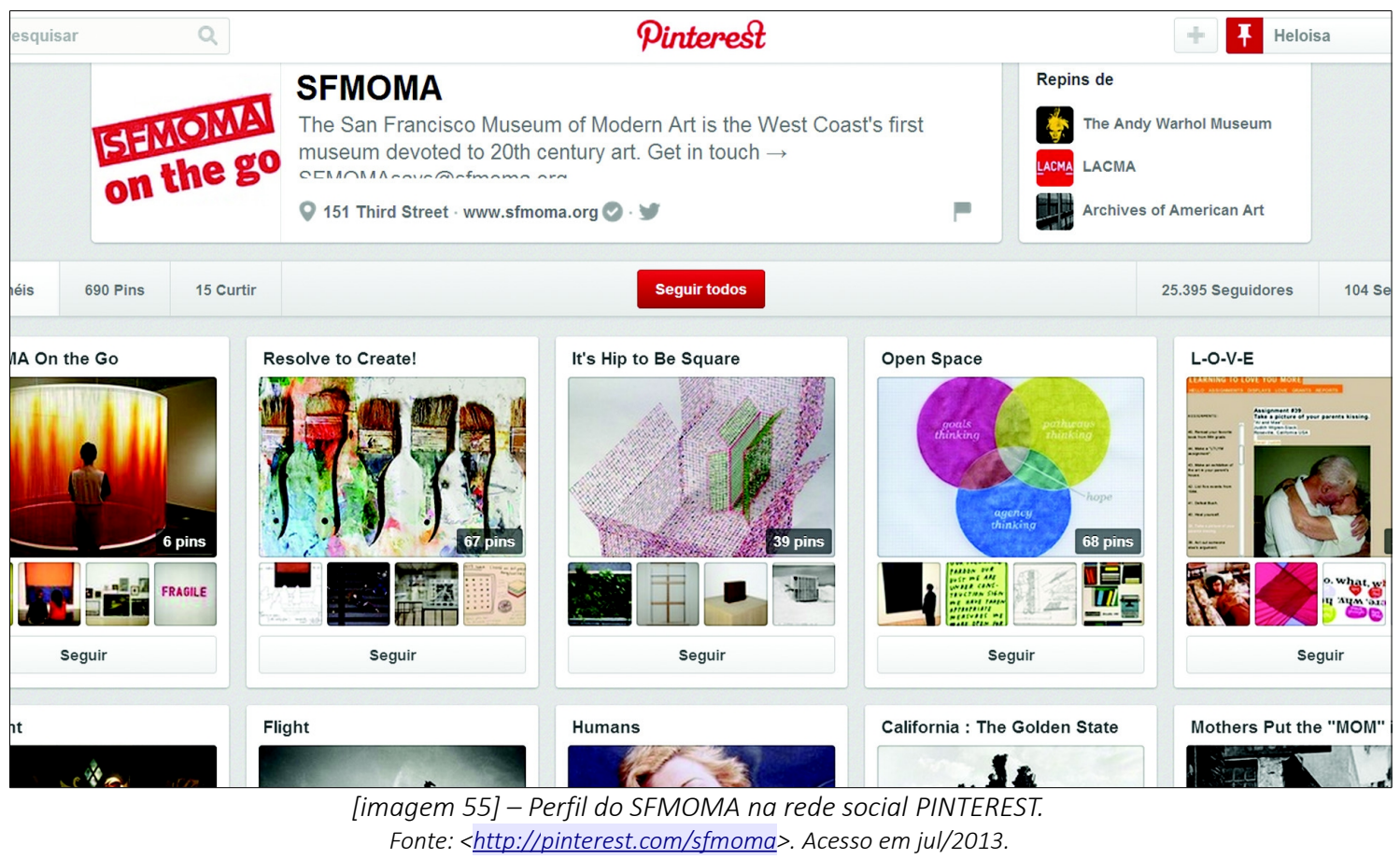


"Delicious has been essential for me. The more bookmarks I save, the more valuable the service becomes."

—Charlie Hoehn, Writer and Marketing Strategist

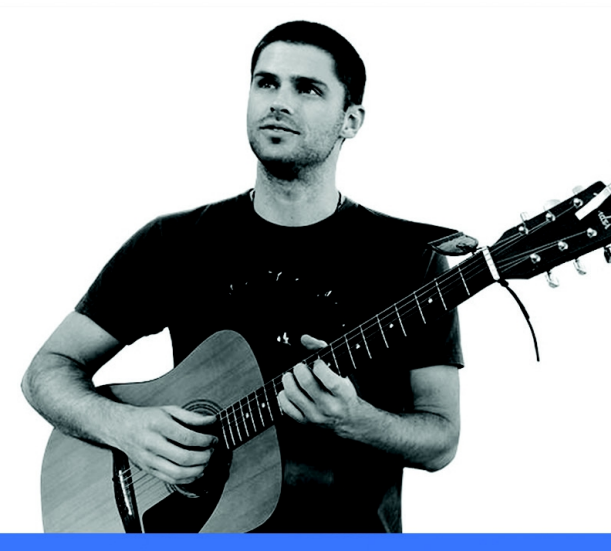

Delicious is an easy, free tool to save, organize, and remember the links you find interesting on the web. 


\subsubsection{MUSEU VIRTUAL DA INTERVENÇÃO URBANA SP: OS SITES DELICIOUS E PINTEREST COMO ESPAÇO MUSEOLÓGICO}

Atualmente, grande parte das pesquisas são feitas na world wide web, além dos arquivos públicos e bibliotecas tradicionais. A iniciativa de colecionar links online que levam muitas vezes meses para serem encontrados, ajuda o trabalho dos pesquisadores e propicia uma maior facilidade na investigação futura que outras pessoas possam fazer sobre a mesma temática. Também, a disponibilização de novos arquivos, nunca antes digitalizados ou recém-criados sobre o contexto, forma uma grande galeria online sobre o assunto estudado, disponível e arquivado de forma aberta na internet.

Para desenvolver um museu virtual contemporâneo com o intuito de divulgar materiais sobre intervenções urbanas na cidade de São Paulo, foram eleitas duas redes sociais como ponto de partida. Os sites Pinterest e Delicious, popularmente utilizados para guardar e compartilhar referências, são os repositórios dos artefatos virtuais que fazem parte desse museu e podem ser ordenados em forma de exposições e mostras específicas, ou também, pesquisados livremente através dos perfis sociais do museu.

Como recorte curatorial para o projeto experimental foi escolhida uma pesquisa de 2011 sobre intervenções realizadas por coletivos artísticos na cidade de São Paulo, no final da década de 79 e começo de 80, feita em conjunto com a artista e pesquisadora Maíra Vaz Valente. Através do edital Prêmio Pesquisador 2010 do Centro Cultural São Paulo, foi desenvolvida a investigação Inter(IN)venção - a intervenção artística a partir da ação efêmera na cidade de são Paulo entre as décadas de 70 e 80 [apêndice A]. A pesquisa consistiu em um grande levantamento de material de arquivo (jornais, revistas, vídeos, fotos e entrevistas antigas) no Arquivo Multimeios do CCSP e de outras instituições, além de entrevistas em vídeo com artistas e coletivos atuantes na época. A trabalho resultou em um artigo ilustrado e um projeto de documentário audiovisual a ser finalizado. A exposição de parte da pesquisa em redes sociais é um novo desdobramento que abre mais uma via de acesso aos documentos recolhidos. 
O Museu Virtual da Intervenção Urbana de São Paulo é inaugurado com a exposição Inter(IN)venção, sobre ações efêmeras realizadas por coletivos de jovens artistas de São Paulo nos anos 70 e 80 do último século. São criados perfis nas redes sociais Pinterest e Delicious com o nome Museu Virtual da Intervenção SP [imagens 57 e 58]. Nesses espaços virtuais foram separadas algumas áreas da exposição que contempla os três grupos mais ativos da época: Viajou Sem Passaporte, Manga Rosa e 3NÓS3 ${ }^{138}$.

Através do perfil do museu no site Pinterest, imagens das intervenções realizadas podem ser encontradas separadas em painéis com os nomes dos três coletivos. No entanto, como as imagens estão 'taggeadas', ou seja, descritas por marcadores, o visitante da rede social pode encontrar uma seleção personalizada através da busca por nomes de artistas ou de ações específicas.

No três murais temos algumas fotos encontradas na internet e 'espetadas' diretamente no painel, e também temos muitas fotos da pesquisa enviadas pelo próprio museu para a exposição. No grupo de imagens do Viajou Sem Passaporte, podemos ver fotos de suas intervenções: Trajetória da árvore, Trajetória do curativo, Das duas às quatro, entre outros materiais [imagens 59 e 60]. Dentre as fotos no mural do Manga Rosa, temos inúmeras fotos do projeto Ao ar livre, que teve a participação de muitos artistas da época [imagens 61 e 62]. No material 'espetado' sobre o grupo 3NÓS3, encontramos imagens das ações: Interdição, Ensacamento e Conecção, entre outras [imagens 63 e 64]. O site ainda conta com uma mini explicação dos grupos e dos trabalhos.

I38 VIAJOU SEM PASSAPORTE, MANGA ROSA e 3NÓS3 são três grupos importantes de uma geração paulista de coletivos de artistas formados no final da década de 1970.

O VIAJOU SEM PASSAPORTE, ativo entre 1978 e 1982, nasceu na Escola de Comunicações e Artes da USP e era um grupo de característica heterogênea, com estudantes de diferentes habilitações: música, artes cênicas, cinema, comunicação social e artes visuais. Os oito representantes da primeira formação teriam sido: Raghy, Celso Seabra, Marilda Carvalho, Tula Melo, Beto Melo, Fernanda Pompeu, Carlos Gordon e Beatriz Caldano. 0 MANGA ROSA também atuou entre 1978 e 1982, 0 grupo fez uma série de inserções na cidade de São Paulo inspirados pela poesia concreta. Era composto pelos jovens artistas: Carlos Dias, Chico Zorzete e Jorge Bassani.

0 grupo 3NÓS3 ficou conhecido por usar a cidade como suporte para 0 acontecimento visual e era formado pelos artistas Rafael França, Mario Ramiro e Hudinilson Jr. Atuou entre 1979 e 1982. (URURAHY\&VALENTE, 20II) 
No perfil do Museu Virtual da Intervenção Urbana SP no Delicious ${ }^{139}$, links para artigos, reportagens e vídeos na internet estão separados e 'taggeados' para que possam ser pesquisador por assunto. Lá são encontrados, por exemplo, ligações para os verbetes dos grupos na Wikipedia e na enciclopédia do Itaú cultural, artigos acadêmicos e até uma tese de doutorado americana sobre o tema. Além, da conexão com a própria coleção de imagens do museu no Pinterest ${ }^{140}$ [imagens 65 e 66].

139 MUSEU VIRTUAL DA INTERVENÇ̃̃o URBANA SP no Delicious. Disponivel em: <http://delicious.com/lecamaria>.

140 MUSEU VIRTUAL DA INTERVENÇÃO URBANA SP no Pinterest. Disponivel em: $<$ http://pinterest.com/intervenurbana $>$. 


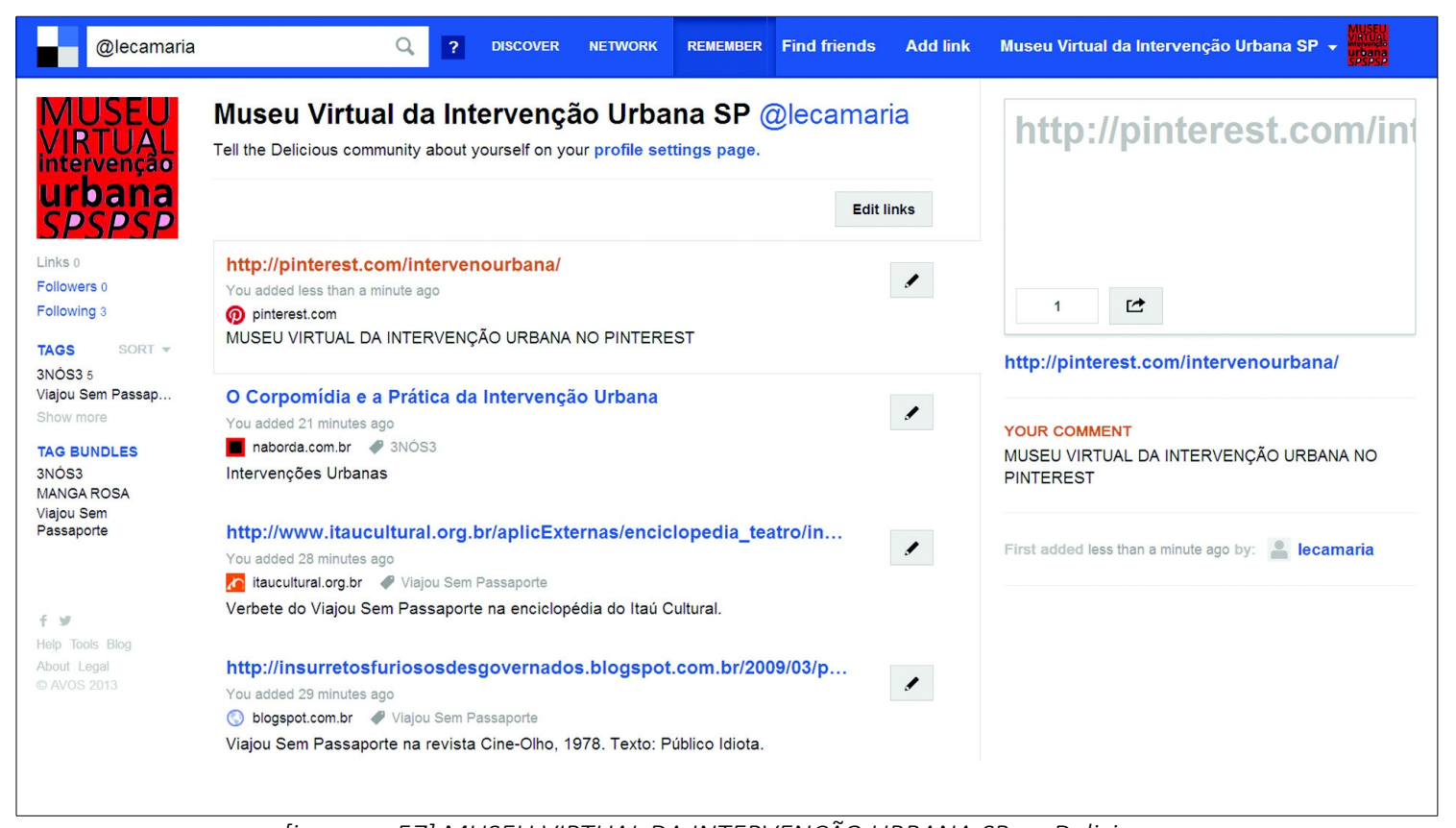

[imagem 57] MUSEU VIRTUAL DA INTERVENÇÃO URBANA SP no Delicious. Fonte: <http://delicious.com/lecamaria $>$. Acesso em jul/2013.

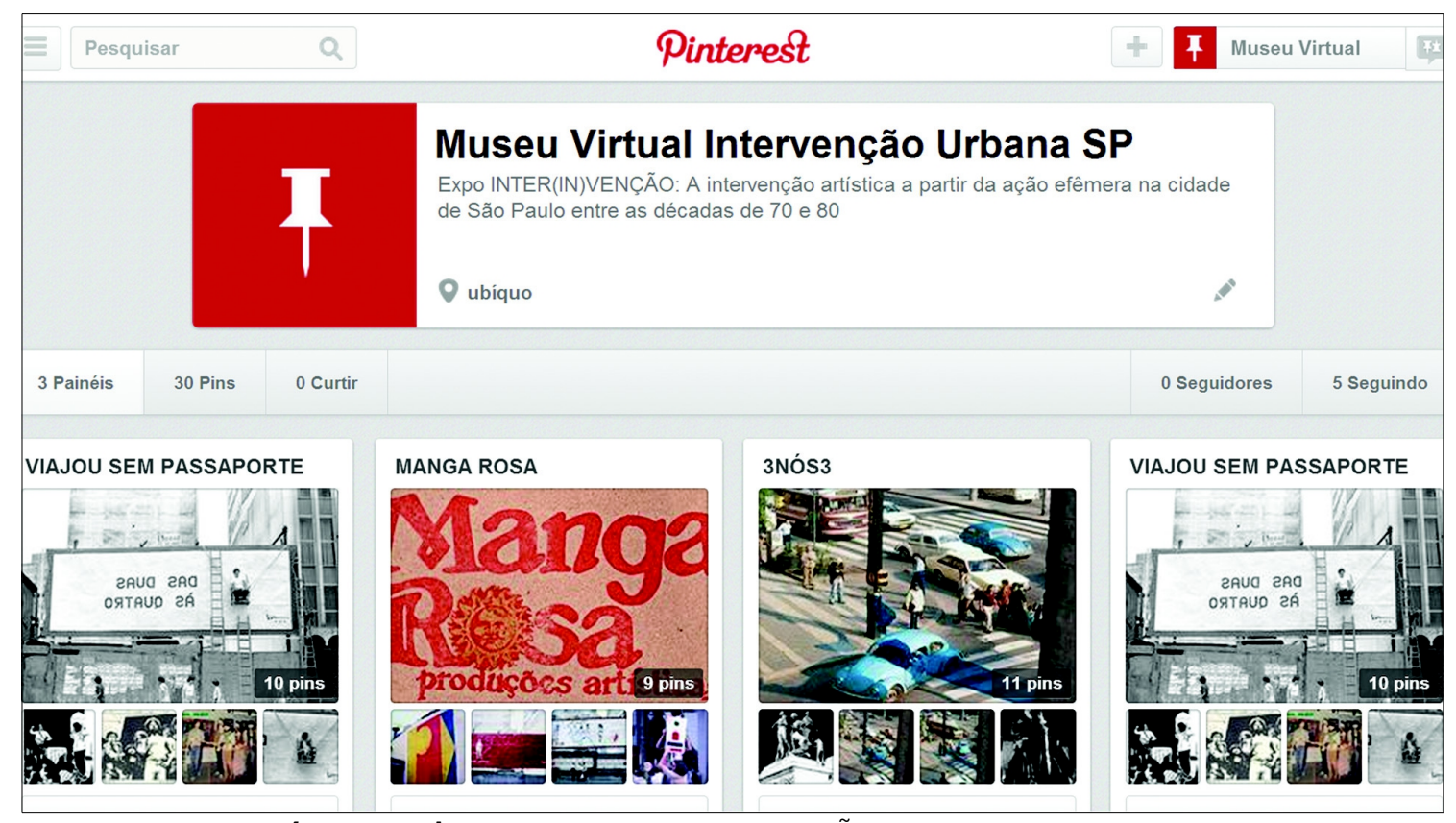

[imagem 58] MUSEU VIRTUAL DA INTERVENÇÃO URBANA SP no Pinterest. Fonte: <http://pinterest.com/intervenurbana $>$. Acesso em jul/2013. 


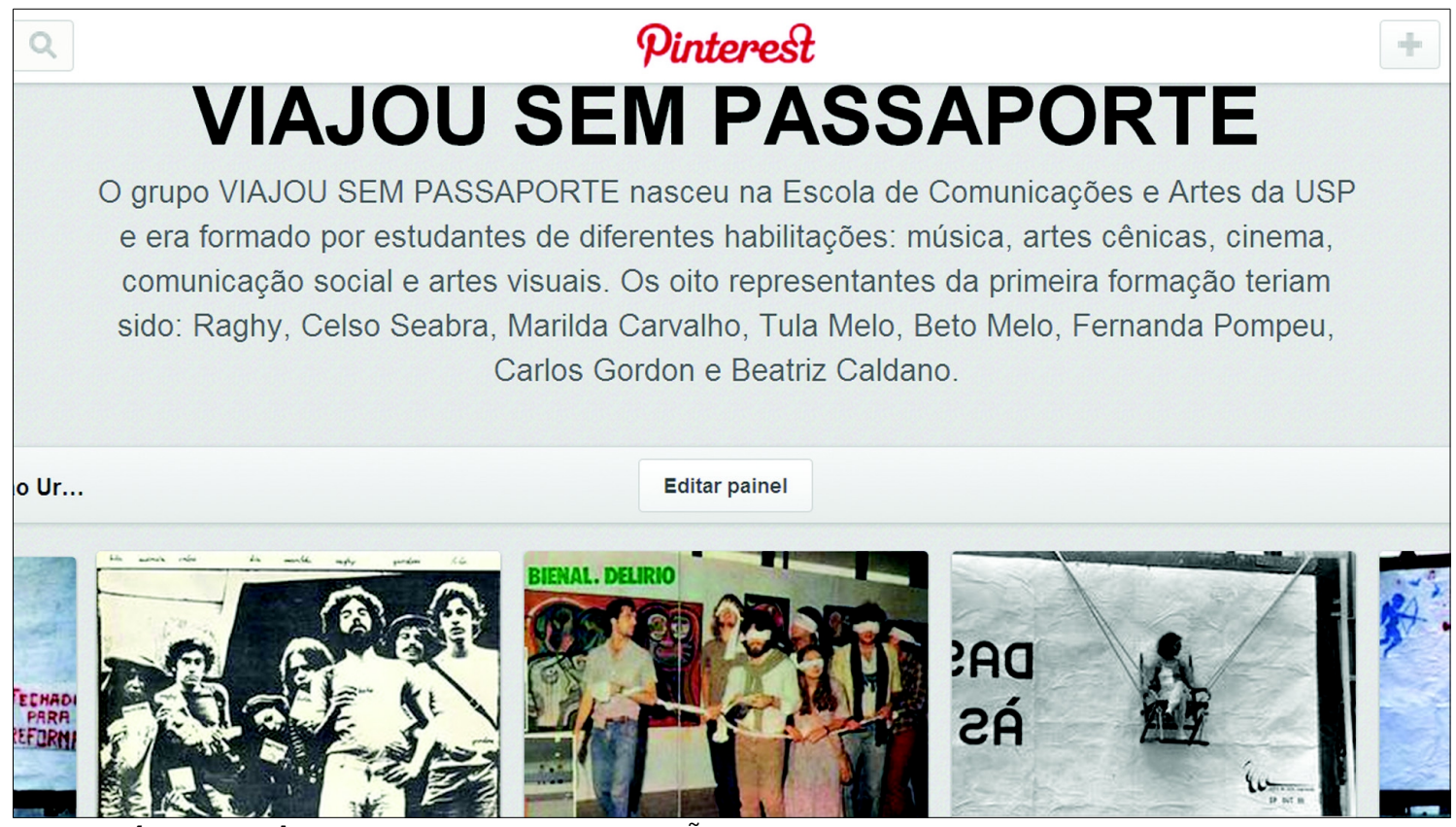

[imagem 59] MUSEU VIRTUAL DA INTERVENÇÃO URBANA SP no Pinterest - Viajou Sem Passaporte. Fonte: <http://pinterest.com/intervenurbana/viajou-sem-passaporte>. Acesso em jul/2013.

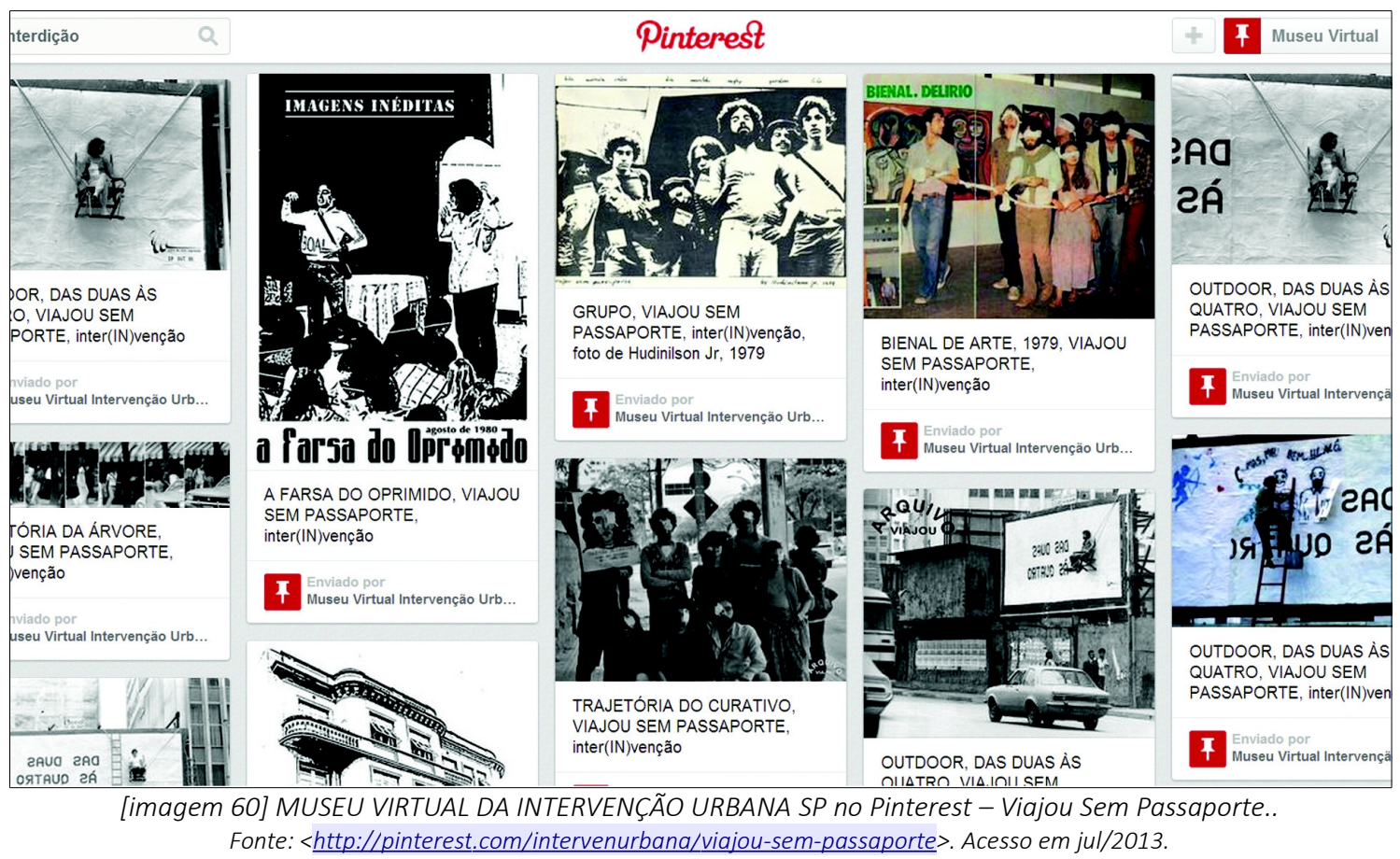




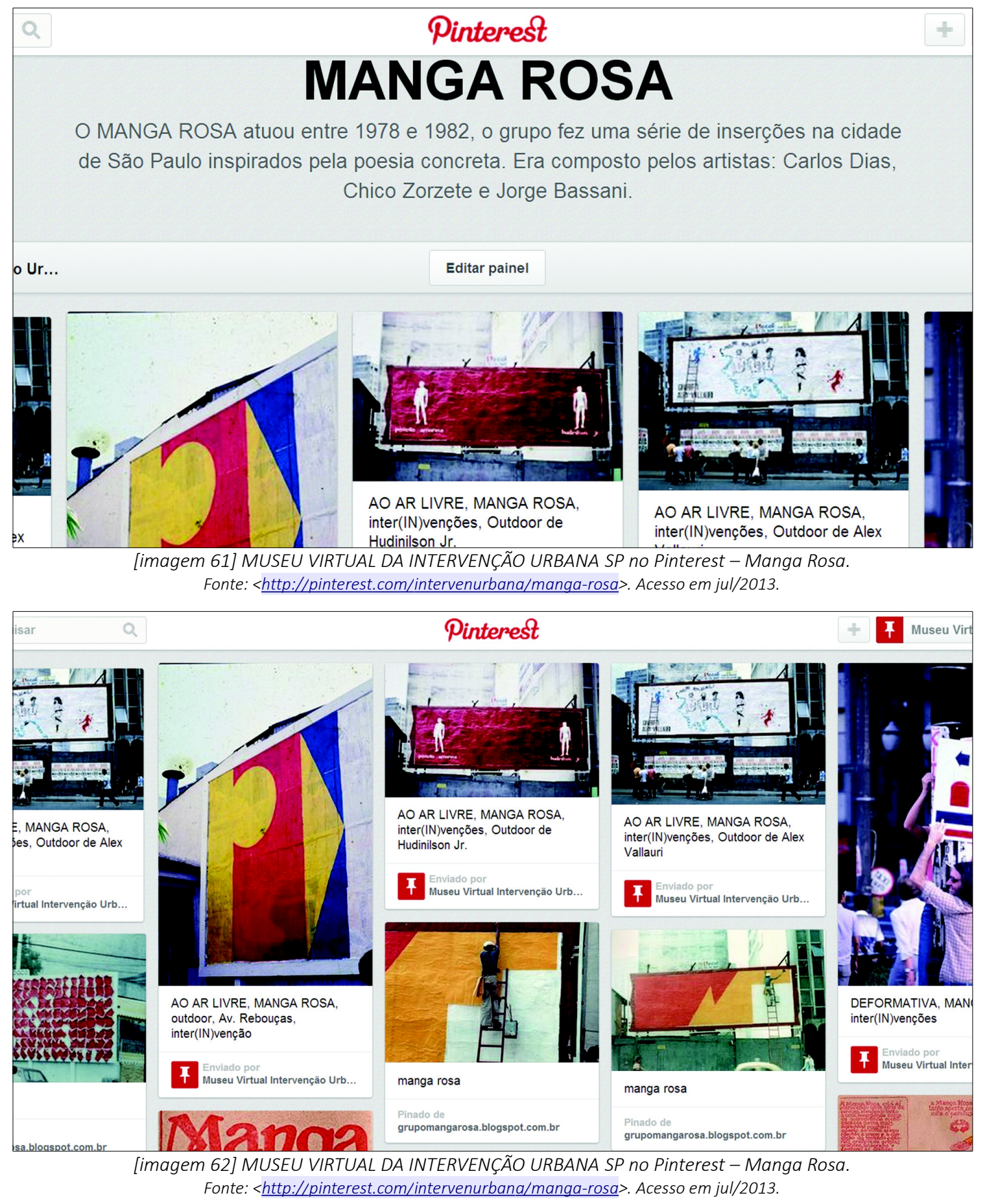




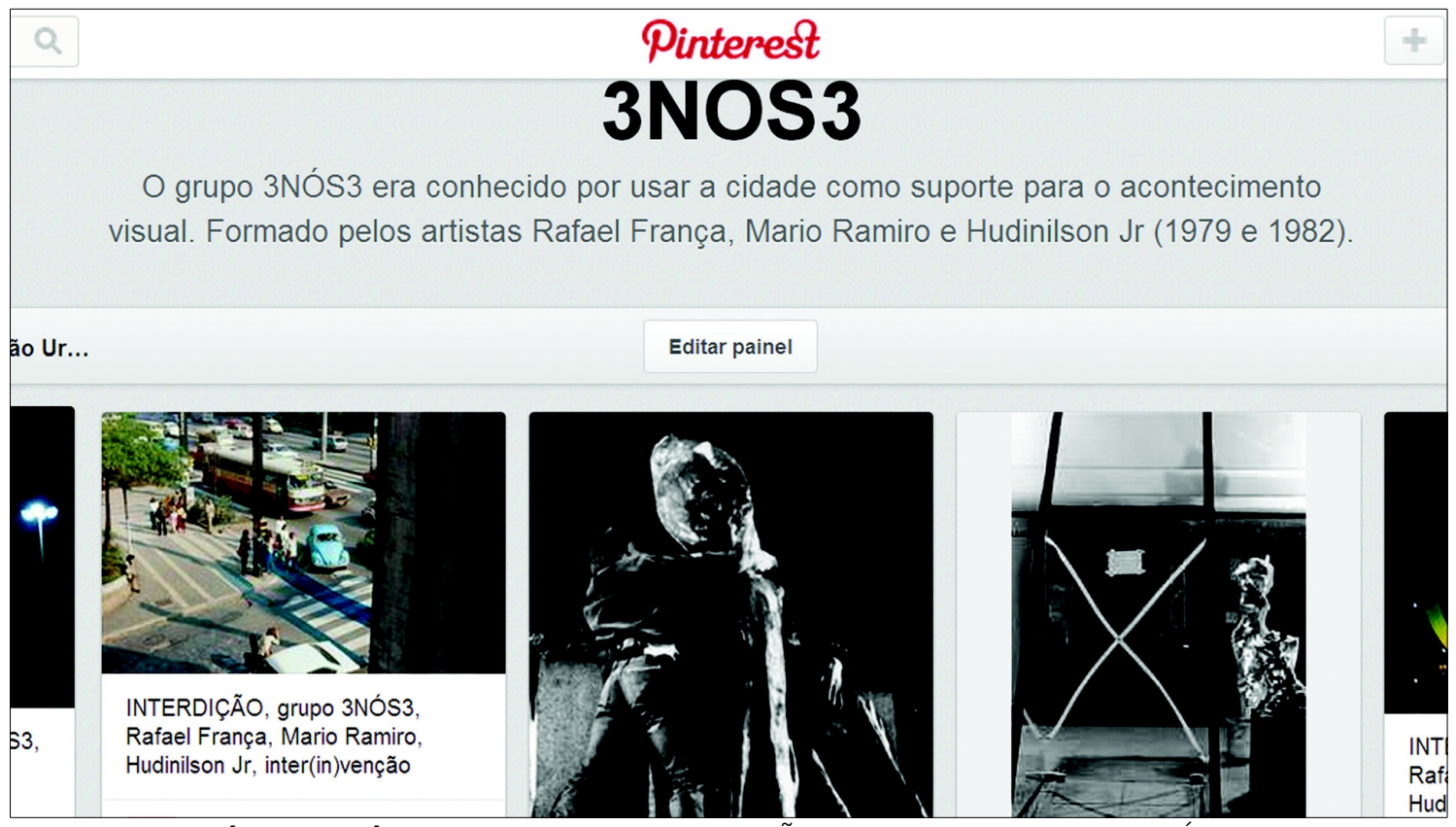

[imagem 63] MUSEU VIRTUAL DA INTERVENÇÃO URBANA SP no Pinterest - 3NÓS3.

Fonte: <http://pinterest.com/intervenurbana/3nós3>. Acesso em jul/2013.

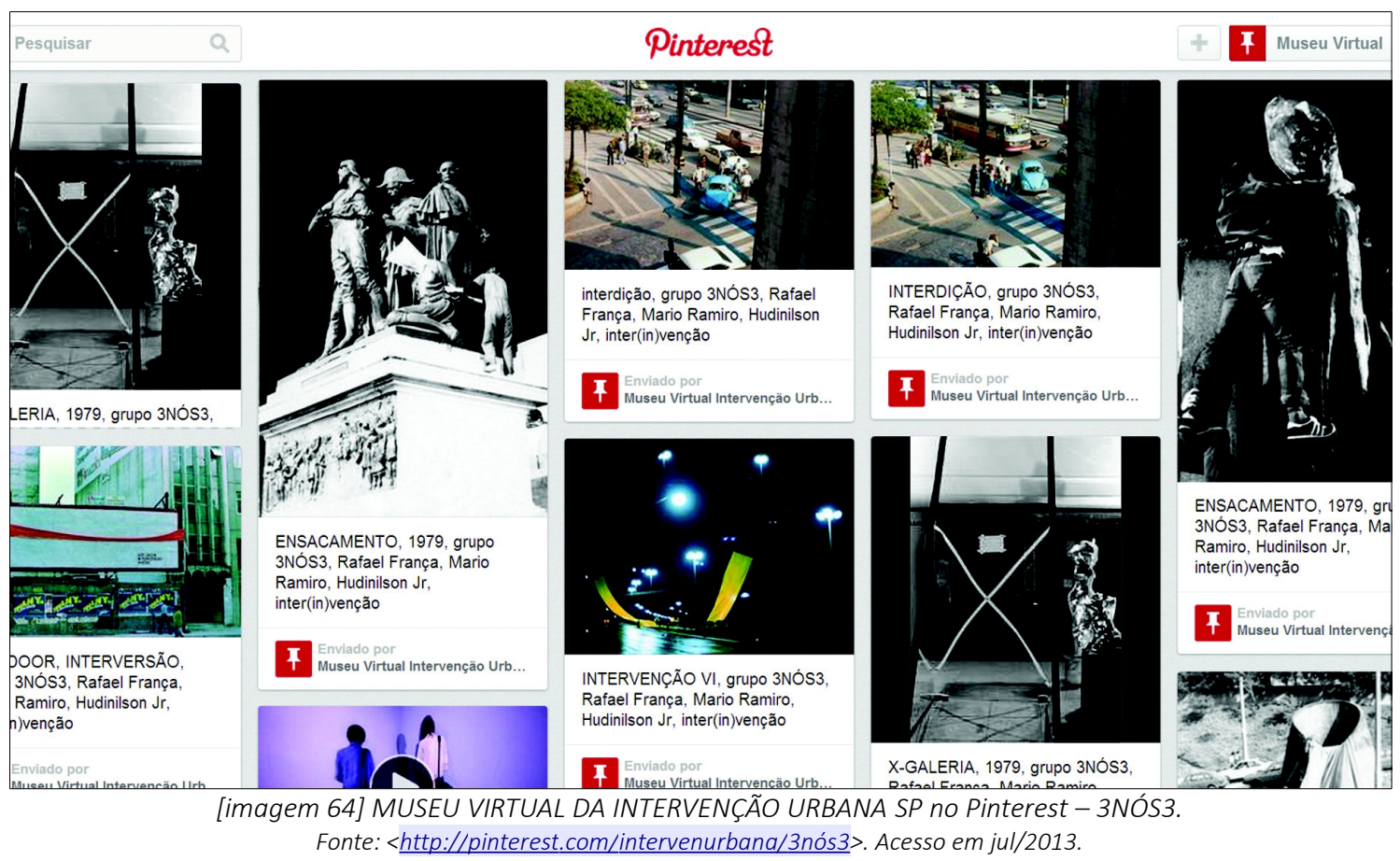




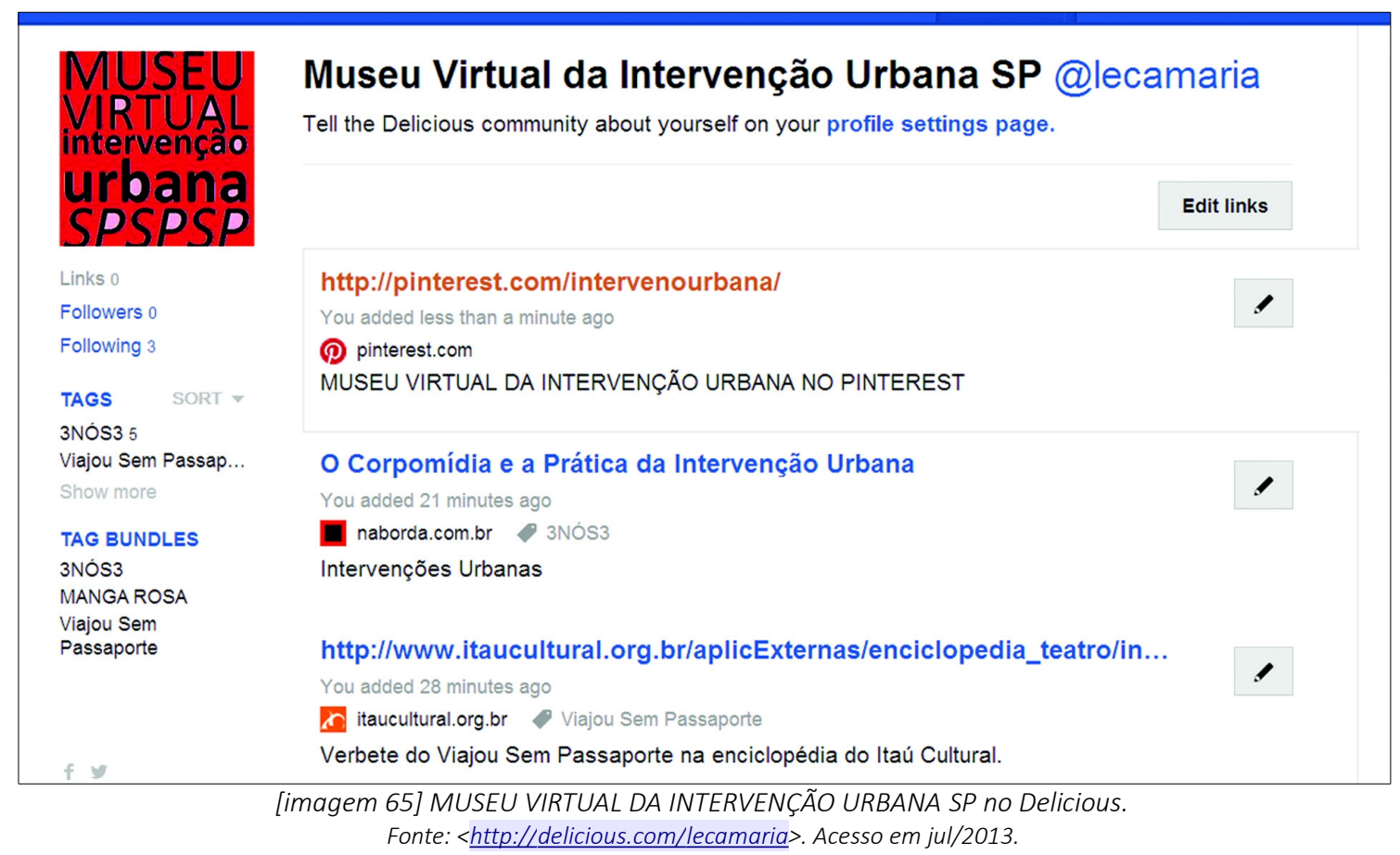

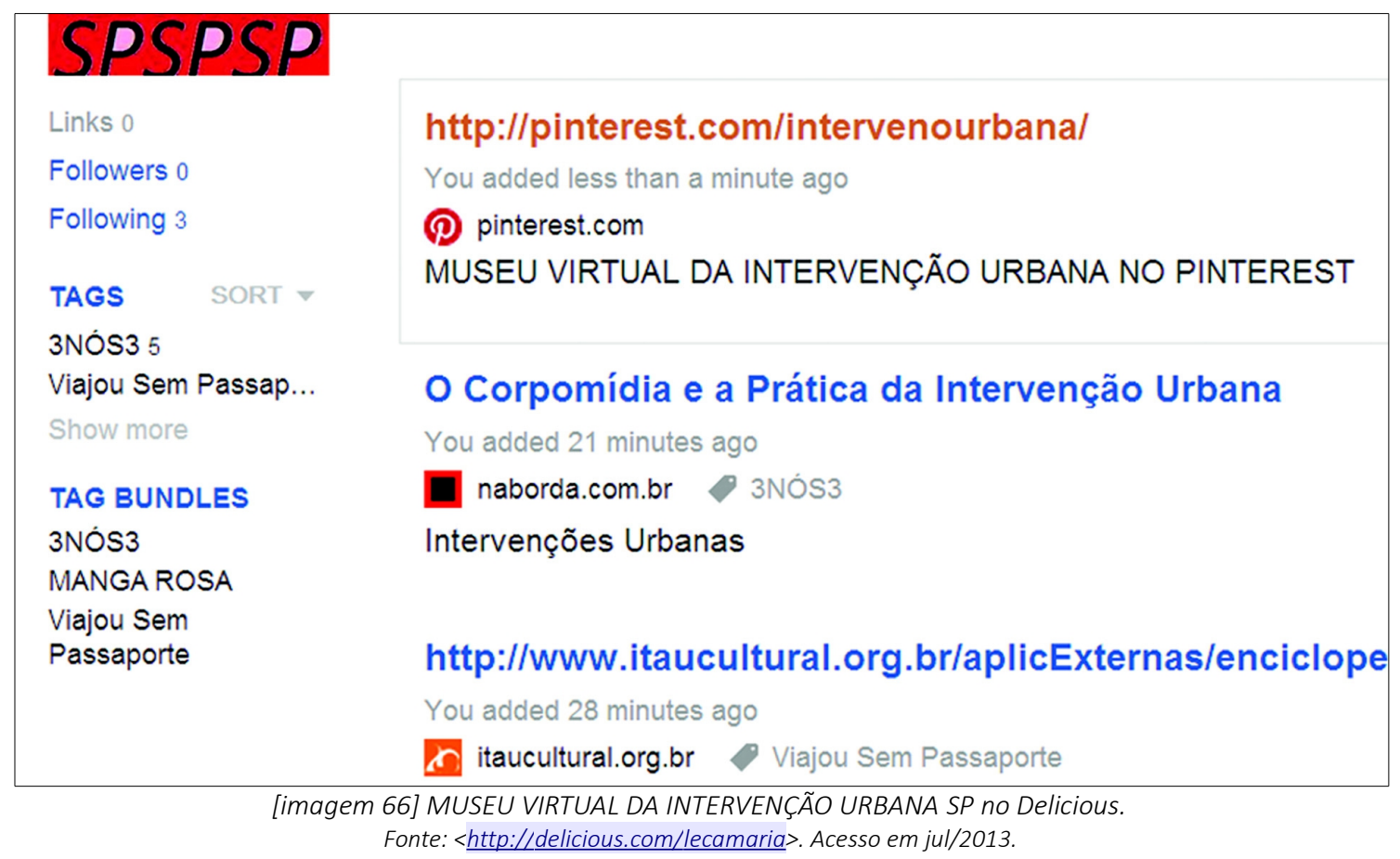


"Os museus podem se tornar mausoléus da cultura histórica reservados para o prazer de uma elite global ou eles podem responder ao desafio de se tornarem conectores culturais para uma sociedade que não sabe mais se comunicar. Em outras palavras, os museus podem continuar 'peças de museu' ou eles podem se reinventar como protocolos de comunicação para uma nova humanidade". [Manuel Castells, 200I] 


\section{MUSEUS, INTERNET E A CRIAÇÃO COLETIVA DA HERANÇA CULTURAL}

\section{I O PAPEL DA INTERNET NA PRESERVAÇÃO DO PATRIMÔNIO IMATERIAL}

A internet se tornou repositório de manifestações culturais cada vez mais específicas e personalizadas. Indivíduos e comunidades tomaram posse dos meios de comunicação e passaram a expressar suas ideias e experiências, coletivas ou individuais. A web traz uma nova possibilidade de compreensão das experiências, vivências e tradições, de um número ilimitado de pessoas. É um organismo crescente do patrimônio imaterial da nossa civilização. Segundo Manuel Castells:

"Os museus são instituições culturais, isto é, sistemas de armazenamento, processamento e transmissão de mensagens culturais potencialmente interativas, em e para, um contexto social determinado. Quanto ao termo cultura, eu o uso no sentido sociológico e antropológico clássico de um sistema de valores e crenças que informam o comportamento das pessoas e que são articuladas e expressas através de instituições sociais." ${ }^{141}$

Castells também reflete sobre o papel dos museus e a incomunicabilidade dos códigos culturais com a fragmentação da produção de sentidos e expressões culturais por múltiplos atores:

"Qual a capacidade que os museus têm para intervir na significativa contradição cultural que está surgindo na era da informação? Esta contradição que consiste na corrente alternada entre, por um lado, a criatividade tecnológica e da comunicação cultural global e, por outro, uma forte tendência para a individualização de mensagens, a fragmentação da sociedade e a falta de códigos compartilhados de comunicação entre

I4I CASTELLS, 2010, p. 428. [tradução livre] 
identidades particulares. Dito de outro modo, por um lado, vemos uma sociedade em rede, uma sociedade de hiper-comunicação emergentes e, por outro lado, vemos uma ruptura da comunicação entre identidades particulares"142.

Relevando também a multiplicidade contemporânea, García Canclini questiona se museus e globalização seriam compatíveis, pois a "globalização é um movimento de fluxos e redes mais que de identidades visíveis, colecionáveis e suscetíveis de exibição". Ele aponta que os objetos culturais da globalização não são facilmente identificáveis, pois não são objetos materiais e sim, "circuitos ou redes comunicacionais"143. Lembra que apesar de já existirem museus que documentem experiências ou conceitos itinerantes (como museus da imigração ou do holocausto, por exemplo), um museu da globalização - ou de 'redes comunicacionais' - traria muitos desafios:

"A museografia (de um museu da globalização) deveria ser flexível e fomentar que as perguntas, 'Isso é parte da globalização?' ou 'Isto merece fazer parte desse museu?', tivessem muitas respostas legítimas. A questão chave seria quem tem direito de dizer isso ou como dar recursos para que muitos possam responder essas perguntas" 144 .

Canclini acredita ser fundamental que sejam muitos a darem as respostas e contribuições ao museu global. Que o legado patrimonial da globalização seja mais do que a interdependência entre povos e sim, a criação de uma visão do mundo formada, essencialmente, de contrapontos ${ }^{145}$.

Ocorrem grandes mudanças na chamada 'economia da informação' que possibilitam a grupos e indivíduos com motivações e crenças diversas, uma maior habilidade para gerar ideias e fazê-las circularem além de seus próprios círculos de convivência $^{146}$. Observamos hoje, inúmeras ações de instituições culturais ou

142 CASTELLS, 2010, p. 427. [tradução livre]

143 CANCLINI, 2007, p. 100-101. [tradução livre]

144 Idem, 2007, p. II0. [tradução livre]

145 Idem, 2007, p. 110.

I46 JENKINS, Henry. 0 que aconteceu antes do YouTube? In: Burguess, Jean; Green, Joshua. YouTube e a revolução digital. São Paulo, Aleph, 2009. p. I50. 
iniciativas independentes para desenvolver formatos que possam armazenar conteúdo que represente patrimônio imaterial para a sociedade.

O Museu da Pessoa ${ }^{147}$, iniciado em São Paulo em 1991, é um museu virtual de histórias de vida. Seu acervo contém depoimentos, em áudio e vídeo, de pessoas comuns que contam sua trajetória, além de fotografias e outros documentos. Seu interesse é pelo homem comum, anônimo ou célebre, e pelas experiências vividas. $\mathrm{O}$ objetivo é proporcionar espaço para a memória oral, e para a valorização do papel de cada indivíduo na construção da nossa história. No site do museu fica aberto um espaço para que qualquer um possa enviar o seu conto de vida [imagem 67].

Temos também um projeto de museu em mídias móveis, o Cleveland Historical ${ }^{148}$, formado por conteúdo criado com a memória da comunidade local. Uma colaboração entre estudantes, professores, comunidades e organizações culturais foi formada para mapear a cidade de Cleveland (EUA) em um aplicativo para smartphones. O grupo conseguiu mostrar a trajetória do município através de narrativas e memórias orais contadas em vídeos feitos pela própria comunidade [imagem 68].

As tecnologias abertas da internet possibilitam que todas as pessoas façam parte da criação coletiva de uma nova história da civilização. Projetos como a Wikipedia atribuem a cultura popular como a maior fonte possível de informações variadas e atualizadas. A Wikipedia é uma enciclopédia online, colaborativa, multilíngue e livre de direitos de autor. Até o momento, possui 27 milhões de artigos escritos por voluntários ao redor mundo. As pessoas também são livres para editar os verbetes publicados. Apesar da enciclopédia online já ser a fonte de pesquisa mais usada entre estudantes, ainda há um grande preconceito quanto ao seu uso em trabalhos acadêmicos. Sua precisão e confiabilidade continuam alvo de críticas, ainda que o site mantenha uma forte política de verificabilidade e pontos de vista neutros, e que pesquisas tenham apontado que a página comete a mesma quantidade de 'erros graves' que as marcas de enciclopédias mais reconhecidas ${ }^{149}$ [imagem 69].

I47 MUSEU DA PESSOA. Disponivel em: < www.museudapessoa.net>. Acesso em julho/2012.

I48 CLEVELAND HISTORICAL. Disponivel em: < www.clevelandhistorical.org >. Acesso em julho/2013.

149 WIKIPEDIA. Disponivel em: <www.wikipedia.org >. Acesso em julho/2013. 
Empresas públicas e privadas também desenvolvem novas formas de acesso a tecnologias de construção de museus virtuais. O Virtual Museum Transnational Network é um consórcio firmado na União Europeia para prover ferramentas que apoiem o desenvolvimento de museus virtuais pelos setores de patrimônio cultural. Com duração de 4 anos, entre 2011 e 2015, o programa pretende realizar palestras, cursos, seminários e workshops, além de disponibilizar inúmeros materiais sobre o tema em seu site [imagem 70]. Já a TourSphere ${ }^{150}$ é uma empresa de tecnologia que oferece serviços pagos no qual o próprio cliente pode construir seu aplicativo para um tour virtual no ambiente de sua escolha. Seu foco são pequenos museus, hotéis, cidades, parques e universidades [imagem 71].

Ao direcionar as comunidades ao consumo e produção de conteúdos digitais, as instituições culturais tomam um papel proativo no desenvolvimento da nova alfabetização midiática, possibilitando experiências diretas de participação artística e gerando ambientes para o engajamento da comunidade. Esse treinamento na 'nova alfabetização' tem resultados poderosos: a comunidade recebe o poder de criar sua própria história digital. Histórias apoiadas pela instituição, mas desenvolvidas pela comunidade. Uma coleção de histórias digitais que pode vir a mostrar a identidade de toda uma sociedade ${ }^{151}$.

150 TOURSPHERE. Disponivel em: <www.toursphere.com>. Acesso em julho/2013.

I5I RUSSO, Angelina; WATKINS, Jerry. Digital cultural communication: audience and remediation. In: Theorizing digital cultural heritage - a critical discourse. (Ed.) Cameron, Fiona; Kenderdine, Sarah. Cambridge: The MIT Press, 2007, p. I5I. 


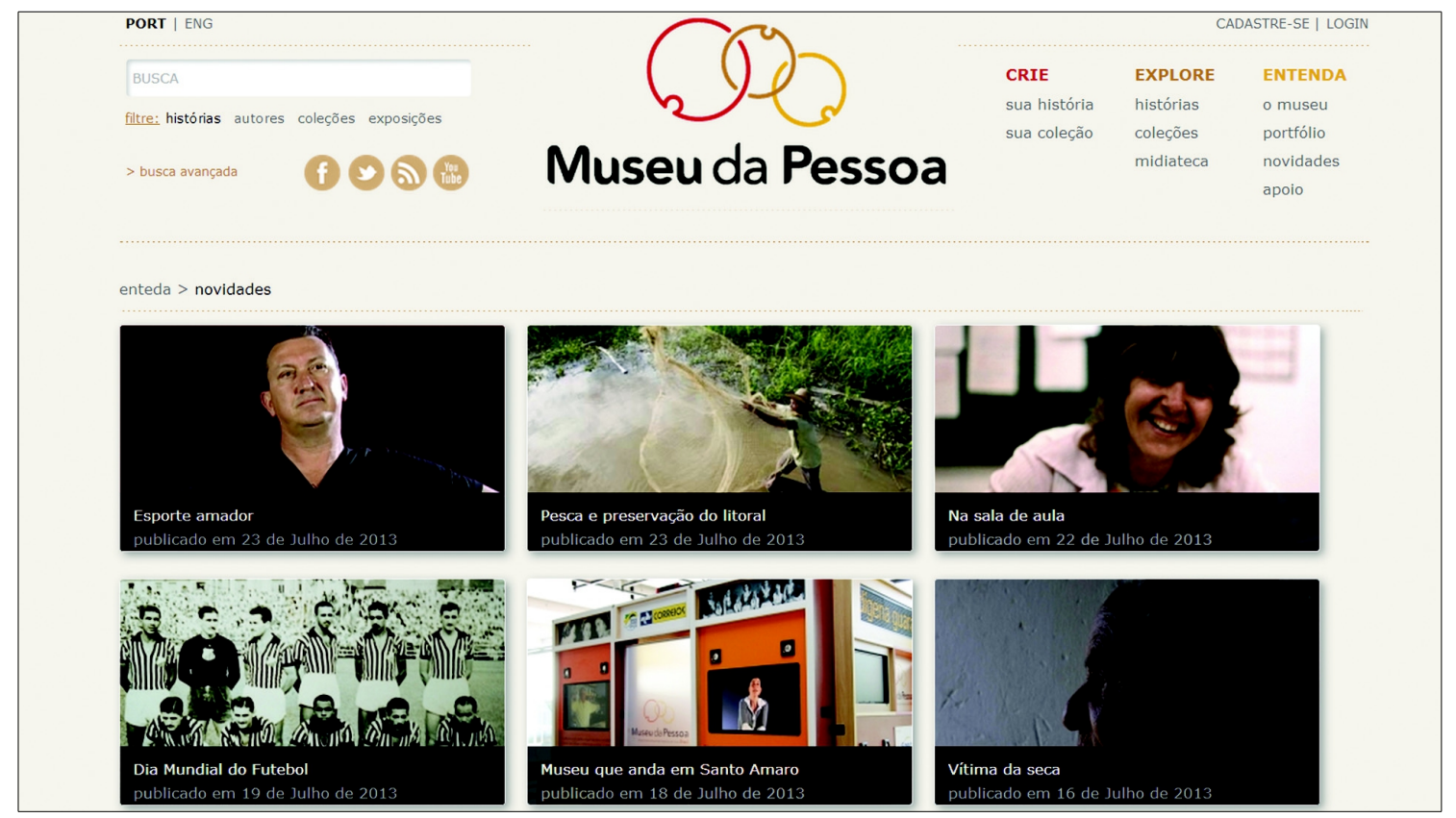

[imagem 67] Site do MUSEU DA PESSOA de São Paulo.

Fonte: <www. museudapessoa.net $>$. Jul/2013.

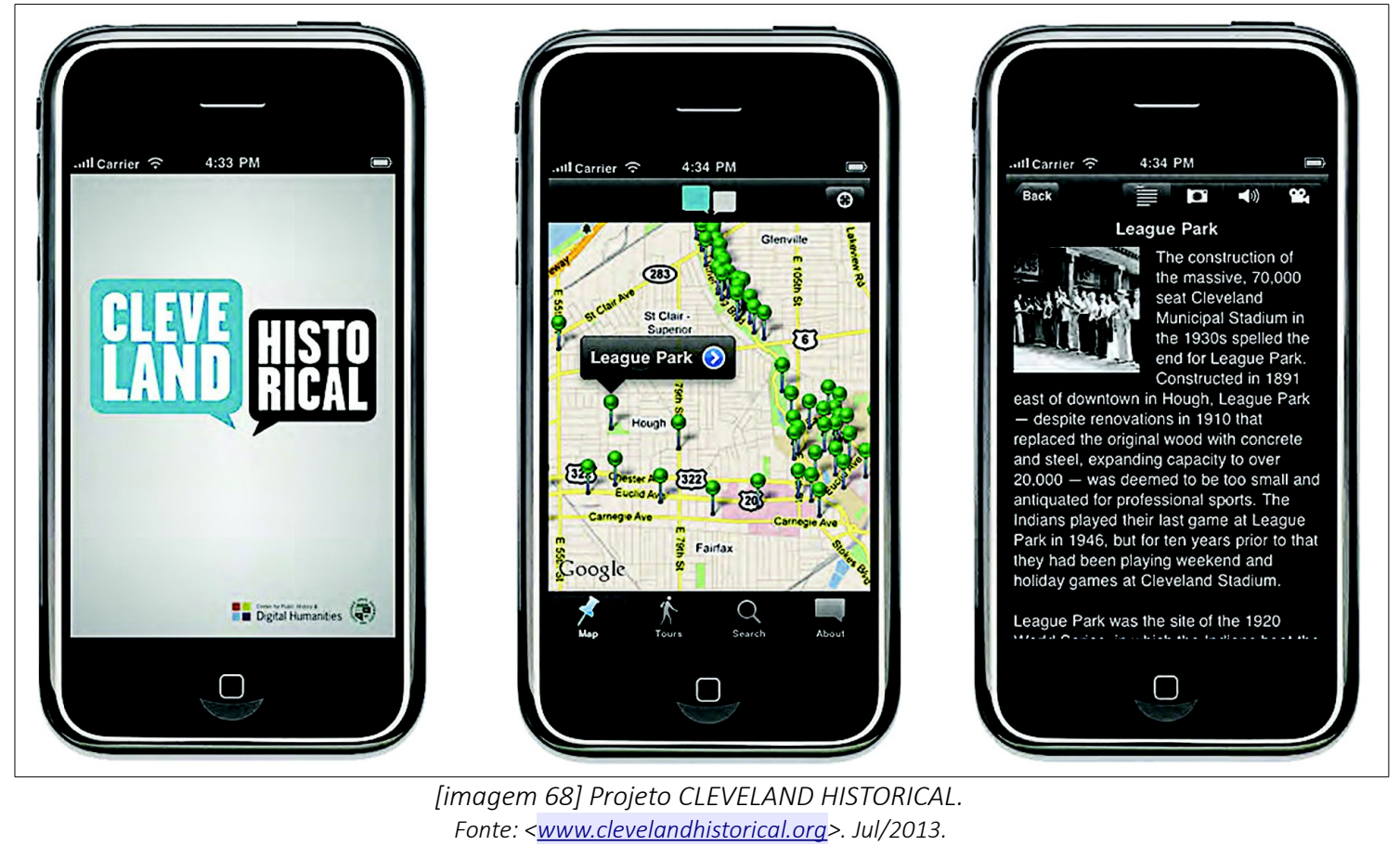




\section{WIKIPEDIA}

English

The Free Encyclopedia

$4240000+$ articles
Español

La enciclopedia libre

$1020000+$ artículos
Русский

Свободная энциклопедия

$1000000+$ статей

Deutsch

Die freie Enzyklopädie

$1590000+$ Artikel

Italiano

L'enciclopedia libera $1030000+$ voci

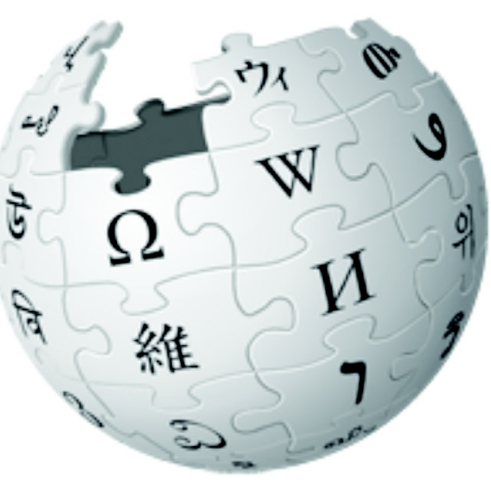

[imagem 69] Website da WIKIPEDIA

Fonte: <www.wikipedia.org >. Jul/2013.

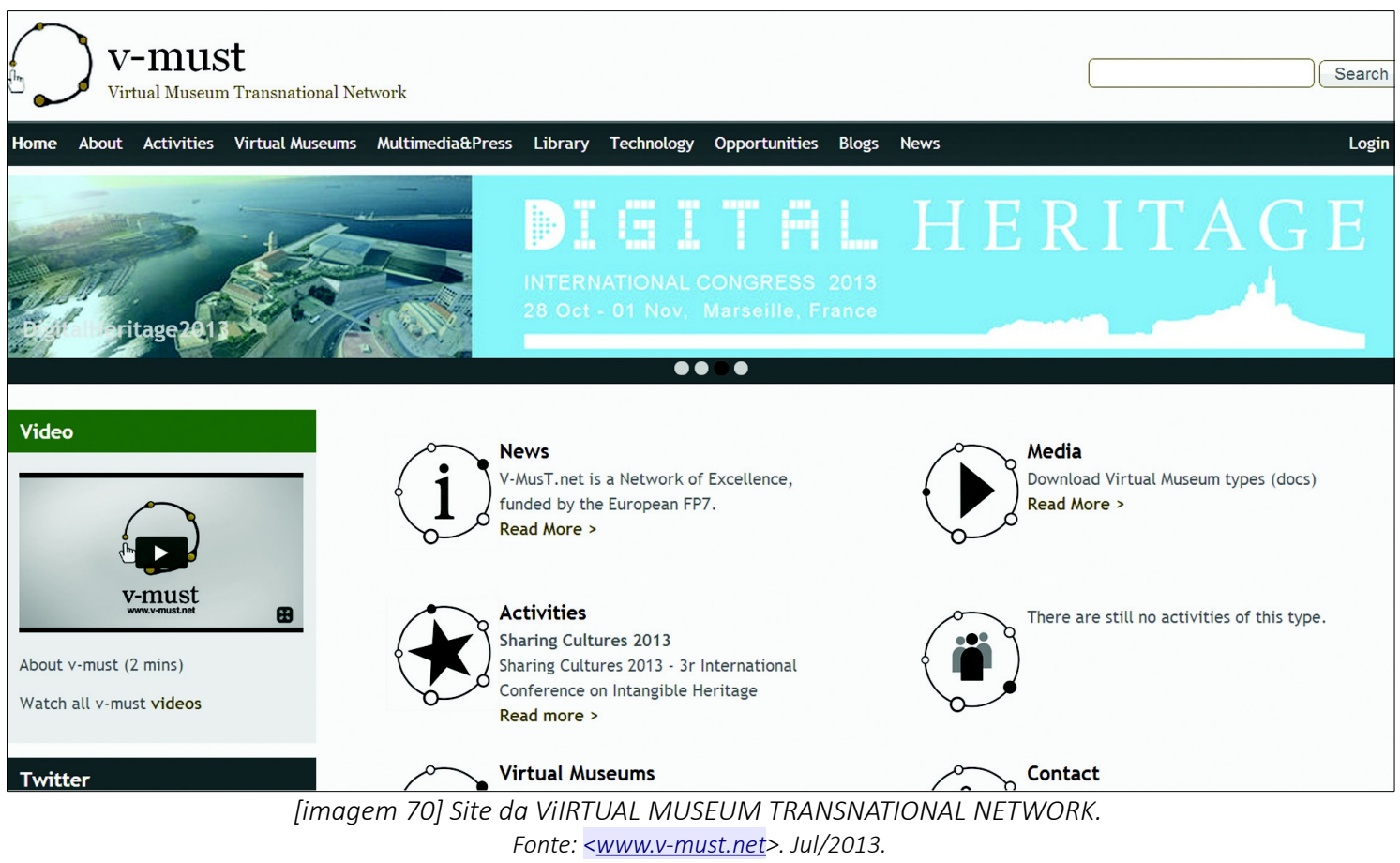




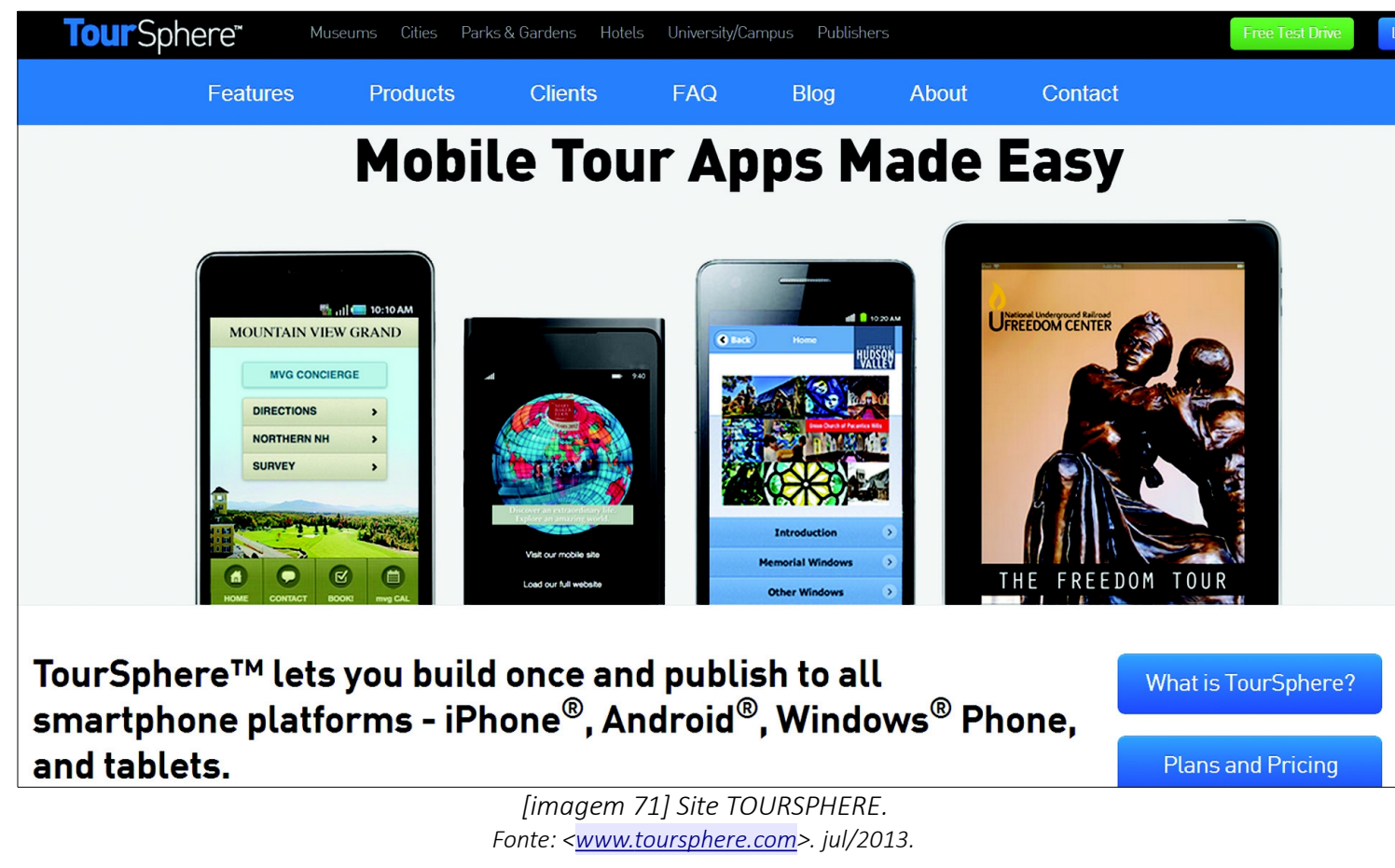




\subsection{CRIAÇÃO COLETIVA DE UMA HERANÇA CULTURAL GLOBAL}

\subsection{CRIAÇÕES COLABORATIVAS E PATRIMÔNIO CULTURAL}

A informação e a cultura estão se transformando em fatores muito relevantes economicamente na sociedade devido a sua grande influência no comportamento das pessoas. Os museus adentraram o mundo da internet com o objetivo de ganhar maior visibilidade social. Com o passar do tempo, puderam perceber que era a sua própria função na sociedade que poderia se expandir através desse meio. A cultura e a arte passam a ser um bem social acessível a todos, valorizado e incentivado por instituições, governos, e indivíduos. Hooper-Greenhill define o futuro dos museus: "o pós-museu é um lugar de mutualidade, no qual o conhecimento é construído em vez de transmitido, através do acúmulo de múltiplas subjetividades e identidades" ${ }^{152}$. Watkins e Russo comentam que as novas mídias possibilitam programas de colaboração interinstituições com o potencial de criar uma rede compartilhada e confiável de herança cultural na qual os visitantes podem seguir temas e associações livres do ditado pelas instituições individuais ${ }^{153}$.

Neste momento, é cada vez mais necessário que agentes tenham interesse em criar formatos que possam realmente aproveitar a função informativa e educativa do meio virtual. Os museus devem entender que o novo modelo de interação instituiçãoespectador permite a criação de um conteúdo muito mais amplo, ao anexar uma enorme variedade de informações geradas constantemente pela própria comunidade de usuários a seu grande acervo institucional, formando assim, um gigantesco mapa de herança cultural da sociedade.

152 (Eilean Hooper-Greenhill, 2000) in: ARVANITIS, Konstantinos. Museums outside walls: mobile phones and the museum in the everyday. In: Parry, Ross (ed.) Museums in a age digital. USA: Routledge, 2010, p. I7I. [tradução livre]

153 RUSSO, Angelina; WATKINS, Jerry. Digital cultural communication: audience and remediation. In: Theorizing digital cultural heritage - a critical discourse. (Ed.) Cameron, Fiona; Kenderdine, Sarah. Cambridge: The MIT Press, 2007, p. 155. 
García Canclini acredita que os novos trabalhos dos museus repensarão o sentido de colecionar, guardar e descartar. Que suas tarefas não devem se restringir apenas a organizar o passado e deixá-lo apresentável:

"Não se pretende que sejam anuladas as noções do próprio e do alheio, mas que se faça possível imaginá-las, em alguns momentos, como intercambiáveis. Sem iludirmo-nos que seja suprimida a diferença entre o familiar e o raro - talvez sempre necessitemos desta distinção para nossa segurança afetiva - mas que se possa estimular uma curiosidade não agressiva, até feliz. Classificar e inventariar, com menos interesse em disciplinar o entorno (...) que em dar lugar ao desconhecido"154.

Para Castells, os museus podem fazer a ponte comunicacional entre diferentes identidades, transportando arte, ciência e experiências humanas, conectando diferentes temporalidades e dimensões da sociedade. O desafio é articular os arquivos que já existem com as projeções do futuro, dentro da experiência de viver o presente, e sem perder o contato com a vida. Os museus "devem ser capazes de articular a cultura viva, a prática do presente, com o patrimônio cultural, não apenas no que se refere à arte, mas também no que se refere à experiência humana” ${ }^{155}$.

Segundo Ascott, a cultura museológica está em fase de mutação para uma "digicultura", com ênfase em "plantar ideias, florescer formas e imagens, colher significado". A divisão entre a criação da arte fora do museu e a curadoria da arte dentro do museu irá se dissipar ao ponto de o interior se tornar um "campo fértil" e o exterior sua "interface com a rede planetária". Tal aspecto já é considerado um processo de curadoria, que traz "o papel curatorial e o ato de criação a uma nova síntese produtiva". O museu do futuro não deve ser uma vitrine, um palco ou um repositório estático. Ele será uma plataforma para operações, um recurso internacional, um espaço de interação cultural e de criatividade colaborativa: "Fará história em vez de guardá-la. Será futuro-ativo em vez de passado-passivo"156.

I54 CANCLINI, 2007, p. II0-III. [tradução livre]

155 CASTELLS, 2010, p. 432-433. [tradução livre]

156 AscotT, 1996. [tradução livre] 
Russo e Watkins também apontam transformações nos processos curatoriais contemporâneos e definem o novo papel do curador museológico nesta rede:

"Conforme a prática curatorial se desenvolve, curadores estão provendo recursos para possibilitar o público a engajar-se na cocriação de conteúdo. Isso não significa que o papel primário do curador como agente entre tecnologia e conteúdo, patrimônio e programa, vá cessar. Na verdade, esse papel pode ser reforçado por uma aproximação focada no público, como uma decisão de política inclusiva, provendo modelos de colaboração, que permitem que múltiplos pontos de vista coexistam. Quando comunidades se unem a instituições culturais para preservar sua identidade cultural, cada parte pode contribuir partilhando conhecimento cultural e distribuindo esse conhecimento para um público maior"157.

Eles também salientam que as instituições não devem se preocupar com a autenticidade ou qualidade de um material gerado por fontes tão variadas, já que ele derivaria de interpretações distintas da cultura, representando um maior número de pontos de vista. Pois, o novo papel dos museus possibilitado pela rede não é mais o de serem vistos como grandes centros de conhecimento, e sim o de "facilitadores de conexões de informações validadas e confiáveis" ${ }^{\prime 158}$.

Profissionais do meio admitem que os museus já exerceram total comando sobre seu conteúdo, e que isso não é mais possível. Acredita-se que os museus continuarão sendo fontes muito confiáveis de informação, os curadores seguirão sendo as maiores autoridades em determinados assuntos, obras e artistas, no entanto, eles não tem mais controle sobre todos os canais por onde se move ae informação ${ }^{159}$.

157 RUSSO, WATKINS, 2007, p.I53. [tradução livre]

158 Idem, 2007, p. 156. [tradução livre].

159 STEIN, Rob in: SZÁNTO, András. Time to lose control: museums have made great strides in adapting to the digital age but they need to go much further. Art Basel Miami Beach daily edition, 2 dez. 2010. Disponivel em: < www.theartnewspaper.com/articles/Time + to + lose + control/22092>. 


\subsubsection{A DEMOCRATIZAÇÃO DOS MEIOS DE PRODUÇÃO E DIFUSÃO DA CULTURA}

A obrigação de sempre se atualizar aos novos modos de comunicação pode confundir as instituições quando mesclam sua responsabilidade social às suas necessidades de marketing. Christine Paul lembra que estamos em uma sociedade do espetáculo digital que precisa satisfazer seus consumidores com efeitos especiais cada vez mais sofisticados, e que os artistas e instituições que trabalham com novas tecnologias estão sujeitos a esses mesmos requisitos ${ }^{160}$. Para o inglês Peter Lewis, é importante lembrar que não se pode oferecer ao público dos museus o que eles querem, e tratá-los como simples consumidores, mas sim, deve-se oferecer o que é entendido que eles precisam, tratando-os como usuários e participantes ${ }^{161}$.

Essa participação foi apenas possibilitada pelas novas ferramentas de comunicação direta da internet, nas quais os usuários são receptores, criadores e difusores de conteúdo. As redes sociais, hoje o principal canal de interação entre as pessoas, não trabalham com a centralização de informações, muitas não estão ligadas a empresas, a marketing e a publicidade, não são concessões do estado e não se limitam a uma cobertura geográfica precisa. Diferente dos meios de comunicação de massa, os novos meios permitem a personalização, a publicação e a disseminação de informações sem grandes interferências de grupos dominantes ${ }^{162}$.

Nesse momento, o avanço rumo a web semântica parece ser o caminho natural e necessário, já que temos bilhões de pessoas no mundo acessando a internet e oferecendo seu conhecimento livremente na rede. Toda essa informação fica armazenada e pode ser facilmente encontrada e compartilhada. O desafio da próxima geração é conseguir aproveitar esse grande banco de dados sabiamente. Uma grande 'inteligência coletiva' pode ser criada se a web souber processar esses arquivos de forma a recombiná-los em novos tipos de conhecimentos e saberes que os seres humanos não poderiam facilmente construir ${ }^{163}$.

\footnotetext{
160 PAUL, 2008, p. 72.

I6I LEWIS, Peter. The role of marketing. In: Forward planning- a handbook of business, corporate and development planning for museums and galleries. (Ed.) Ambrose, Timothy; Runyard, Sue. London: Routledge, 1993, p. 26.

162 LEMOS, 2009, p. 47-48.

163 CAIRNS, 2013.
} 
No entanto, também é preciso comentar algumas questões sendo levantadas sobre a falsa democracia nos mecanismos da web. Ainda que as buscas na rede sejam impulsionadas pelo apoio de outros usuários, as perspectivas minoritárias podem se manter escondidas por ela ${ }^{164}$. Há uma crescente preocupação com o poder que os mecanismos de busca tem exercido na navegação online ${ }^{165}$. Grandes mecanismos de pesquisa na web, como o Google, podem controlar seus resultados de busca, filtrando, eliminado ou reposicionando os links encontrados. Anúncios pagos costumam ser os primeiros a aparecer nas pesquisas, e muitas pessoas não costumam ler além da primeira página de resultados. A mesma fartura de informações que parece um suprimento inesgotável de conteúdo gerado pelos usuários pode nos desencorajar a questionar que tipo de material não se encontra $\mathrm{ali}^{166}$.

A deficiência na formação de espectadores críticos também é apontada por Canclini, que culpa a persistente desigualdade econômica e as políticas culturais prédigitais. A educação atual ainda insiste em formar leitores de livros e observadores de artes visuais, quando a comunicação e a indústria já estão unindo todas as mídias e suportes. Livros podem ser lidos impressos, no computador ou em um tablet, filmes podem ser assistidos no cinema, na sala de estar ou no celular ${ }^{167}$. Apenas uma interação contínua entre instituições e comunidades podem prover uma nova alfabetização midiática para mudar efetivamente a experiência do público, de consumidor cultural, para produtor cultural ${ }^{168}$.

\footnotetext{
164 JENKINS, 2009, p. 163.

165 GABRIEL, 2009, p. 73.

166 JENKINS, 2009, p. 164.

167 CANCLINI, 2007, p. 24-25.

168 RUSSO, WATKINS, 2007, p. 152.
} 
Acerca dos desafios da real democratização das tecnologias, seus meios de produção e difusão, Jenkins cita o trecho de Ivey \& Tepper em Chronicle of higher education que se transcreve a seguir:

"Cada vez mais aqueles que têm educação, habilidades, recursos financeiros e o tempo necessários para navegar pelo mar das escolhas culturais ganharão acesso a novas oportunidades culturais (...). Eles serão semiprofissionais que se ligam em redes a outros amadores sérios para encontrar audiências para suas obras. Eles descobrirão novas formas de expressão cultural que os unem por suas paixões e os ajudam a forjar suas próprias identidades, e serão os curadores da expressão de suas próprias vidas e os especialistas que tornarão a vida de outros mais valiosas... Ao mesmo tempo, os cidadãos com menos recursos - menos tempo, menos dinheiro e menos conhecimento para navegar pelo sistema cultural - dependerão cada vez mais da ponte cultural oferecida a eles por mídias consolidadas e conglomerados de entretenimento (...) Tais cidadãos ficarão presos do lado de fora da barreira cultural. Assim, as mudanças tecnológicas e econômicas estão conspirando para criar uma nova elite cultural - e novas classes culturais desfavorecidas" ${ }^{\prime 169}$.

Ascott afirma que os museus das próximas gerações devem se preocupar tanto com a democratização da mensagem quanto com a democratização dos meios: "Uma vez que a tecnologia da telemática é a tecnologia da consciência, se sabiamente cultivada, pode nos levar a uma participação na criação compartilhada da realidade"170.

169 (Bill lvey \& Steven J. Tepper) in: JENKINS, 2009, p.163-164.

170 ASCOTT, 1996. [tradução livre] 
"O museu será parte de um macro-museu universal, um recurso global. Ao mesmo tempo que também encolherá para ser o micro-museu, uma interface neural minúscula como um biochip ligado ao hipercórtex".

[Roy Ascott, 1996] 


\section{CONSIDERAÇÕES FINAIS: PERSPECTIVAS PARA A RELAÇÃO MUSEUS E INTERNET}

A tecnologia está revitalizando todas as ações dos museus, em especial a sua relação com o público. Há uma nova dinâmica de trocas e parcerias entre as instituições, público, curadores e artistas. Os centros culturais mesclam estratégias tradicionais e inovadoras na tentativa de ampliar o alcance fora de seus prédios físicos e fazer cada vez mais parte da experiência cotidiana de todas as pessoas, principalmente, as que não tinham cultivados hábitos de consumo cultural.

O papel dos museus atuais, digitais ou não, é o de reconstruir e também construir cultura material e imaterial, em conjunto com a população. Porém, eles devem enfrentar desafios que incluem: o reaquecimento do espaço público urbano, o favorecimento da apropriação social das novas tecnologias de informação e o fortalecimento da democratização dos meios de comunicação ${ }^{171}$.

Müller observa a fusão do real e do virtual caracterizando a vida contemporânea, mas acredita que os museus ainda lutam para encontrar a conexão entre artefatos reais e suas representações virtuais ${ }^{172}$. O pesquisador apresenta questões para os museus atuais: Como podem definir a si mesmos? Quão importante é a identidade no mundo digital? Como fixar seu espaço no ambiente virtual sem se tornar fragmentado ou transitório? Ele acredita que os museus continuarão a se reinventar no mundo digital, na tentativa de garantir que sua missão de ajudar as pessoas a explorar suas

I7I LEMOS, 2009, p. 45.
I72 MÜLLER, 2009, p. 296. 
memórias, cultura e identidade seja cumprida também no século XXI ${ }^{173}$.

Para Castells, museus devem unir-se a outros centros culturais e se transformarem em espaços de inovação e experimentação, além de repositórios do patrimônio material. Devem estar em contato com a sociedade, ser instituições educativas e interativas, ancoradas em um grupo identitário específico, mas também abertos a novas correntes multiculturais. Devem ser capazes de sintetizar a arte, a experiência humana e a tecnologia, criando novas formas de comunicação e expressão ${ }^{174}$. Ele acredita que: "A arte como uma expressão híbrida de materiais físicos e virtuais no presente e no futuro pode se tornar um elemento essencial na construção de pontes entre a Rede e o $\mathrm{Eu}^{\prime \prime 175}$.

A relação que o público tem com a arte, o conhecimento e a informação tem exigido novas formas de dinâmica e interação. Segundo Ascott, os artistas deverão criar sistemas que capacitem o público a produzir suas próprias experiências e sentidos. O museu se tornará um lugar de transformação, engajado na construção de consciência e comportamento, esclarecendo e codificando as nossas percepções. Seu papel mudará, não será mais o guardião de uma realidade oficial, mas o guia para uma realidade emergente. Será tomado por artes da conectividade, da interação e da experiência colaborativa. Não unirá apenas pessoas e distâncias, mas também ideias e diferenças. Sua ênfase ficará mais na ação, interação e construção do que no armazenamento, classificação e interpretação ${ }^{176}$.

Ascott também apresenta o conceito de "cibercepção", que implica uma reestruturação do modo de viver, não realizada apenas com um novo corpo e uma nova consciência, mas com a redefinição total de como devemos habitar o interespaço entre o virtual e o real. A cultura telemática leva a uma conexão internacional entre pessoas, lugares e mentes. A internet é a infraestrutura de uma

173 MÜLLER, 2010, p. 303-304.

174 CASTELLS, 2010, p. 434.

175 Idem, 2010, p. 430.

176 AscotT, 1996. 
consciência global, ou um 'cérebro mundial', como o imaginado por H.G. Wells. Ele vislumbra a inteligência coletiva em forma de rede neural, um "hipercórtex planetário"177. Por fim, Ascott questiona a necessidade de uma dimensão espiritual na arte tecnológica e amplia o apontamento clássico de Benjamin sobre se há aura na reprodução técnica da obra de arte, para 'existe amor no abraço telemático?'.

Muitas são as pesquisas atuais para o aproveitamento das crescentes tecnologias, na inserção das instituições artístico culturais e da própria arte no dia a dia das pessoas. E principalmente, após um recente entendimento, mais ainda tem sido feito para inserção também da vida cotidiana das pessoas e da sociedade na produção da herança cultural que é reservada, alimentada e protegida pelos espaços museológicos.

O caminho dos museus na internet percorreu uma primeira fase do seu uso para distribuição de informações a um público mais amplo; uma segunda fase, na qual se preocupava em oferecer aos visitantes, conteúdos diferentes dos que havia nos museus físicos, investindo na arte computacional; até chegar a uma fase atual, onde as instituições se dispõem a compartilhar a criação e organização de seus acervos com os usuários e a comunidade.

Uma poderosa memória cultural da humanidade tem sido perenemente construída, de forma coletiva, pela população mundial. No entanto, o desafio das grandes instituições é incluir uma grande parte da população que ainda não tem acesso às possibilidades de interação com a arte e a cultura que as novas tecnologias têm trazido a sociedade atual.

177 AsCOTT, 1996. 


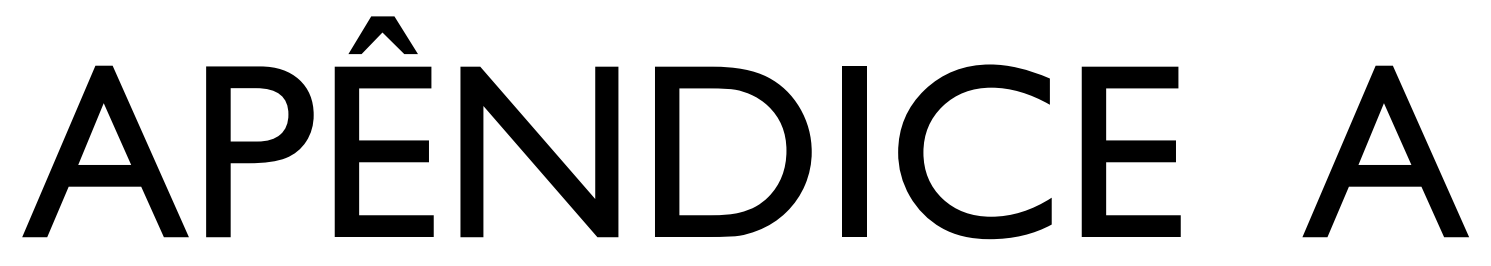

\section{INTER(IN)VENÇÃO:}

\section{A intervenção artística a partir da ação efêmera na cidade de são Paulo entre as décadas de 70 e 80}

[Edital Prêmio Pesquisador 2010 do Centro Cultural São Paulo]

Resumo descritivo da pesquisa:

O projeto de pesquisa intitulado Inter(IN)venção foi selecionado pelo Edital Prêmio Pesquisador 2010 do Centro Cultural São Paulo. $O$ assunto tratado ao longo de dez meses de pesquisa teve como foco a produção de intervenções artísticas no espaço público e urbano a partir de ações efêmeras entre os anos de 1970 e 1980 na cidade de São Paulo. Para tanto, foram escolhidos dois eixos. O primeiro tratou de três grupos de artistas atuantes e bastante importantes entre os anos de 1977 e 1982: Viajou Sem Passaporte (1977-1982), Manga Rosa (1978-1982) e 3NÓs3 (1979-1982). O segundo eixo trouxe dois eventos idealizados e promovidos pelos próprios artistas fora de espaços institucionais: Mitos Vadios (1978) e Evento Fim de Década (1979).

Diante desses objetos de investigação, as práticas de ações no espaço aberto/público nos motivaram a realizar uma série de entrevistas com os artistas participantes e atuantes da época. A pesquisa levou em conta as categorias preexistentes no Arquivo Multimeios do CCSP, Arte Experimental, Arte Urbana, Intervenção Urbana e Performance, como ponto de partida.

PALAVRAS-CHAVE: intervenção, performance, arte urbana, artes visuais, coletivos artísticos.

(Heloisa Ururahy \& Maíra Vaz Valente / novembro de 2011) 


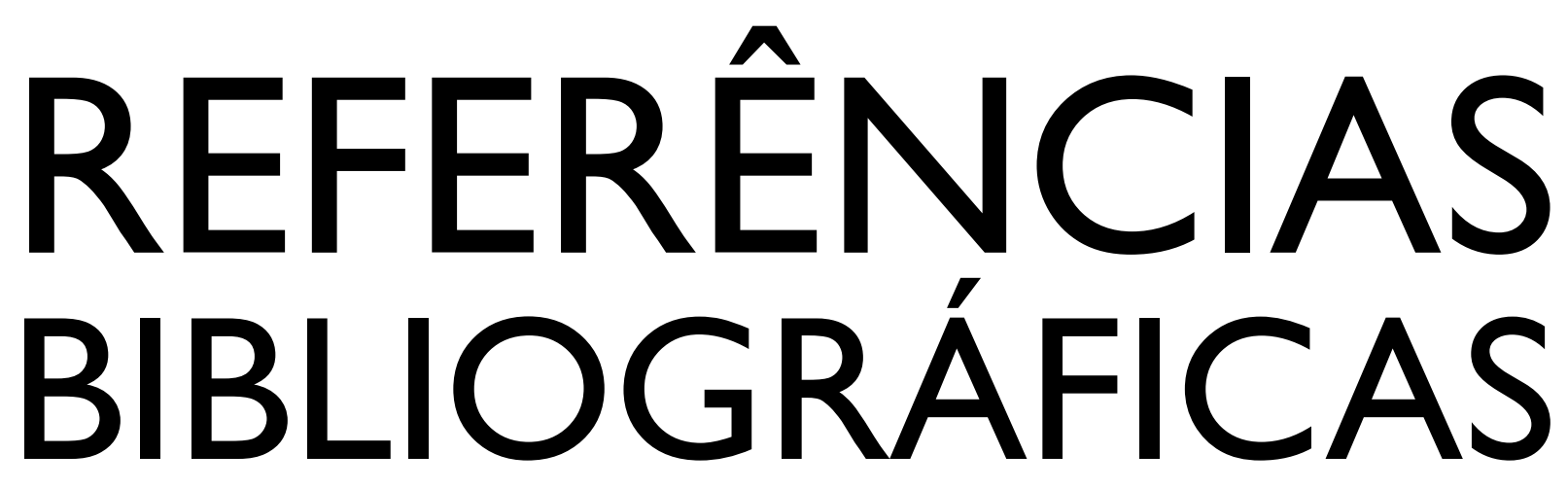

\section{BIBLIOGRAFIA DE REFERÊNCIA:}

\section{TEXTOS:}

ARVANITIS, Konstantinos. Museums outside walls: mobile phones and the museum in the everyday. In: Parry, Ross (ed.) Museums in a age digital. USA: Routledge, 2010, p. 170-175.

ASCOTT, Roy. The Museum of the third Kind. Intercommunication, n.15, 1996. Disponível em: <www.ntticc.or.jp/pub/ic mag/ic015/ascott/ascott_e.html>. Acesso em maio/2013.

BANDELLI, Andrea. Virtual spaces and museums. In: Parry, Ross (ed.) Museums in a age digital. USA: Routledge, 2010, p. 148-152.

BATTRO, Antonio M. From Mauraux's imaginary museum to the virtual museum. In: Parry, Ross (ed.) Museums in a age digital. USA: Routledge, 2010, p. 136-147.

BEALE, Nicole. A quick review of social media on museums' websites. Disponível em: $\leq$ www.theculturalheritageweb.wordpress.com/2011/09/01/what-the-websites-say $>$. Acesso em maio/2013.

BELLIDO GANT, María Luisa. Arte, museos y nuevas tecnologías. Gijón, España: Ediciones Trea, 2001.

BENJAMIN, Walter. A obra de arte na era de sua reprodutibilidade técnica. In: Magia e técnica, arte e política: ensaios sobre literatura e história da cultura. São Paulo: Brasiliense, 1994.

BURNETTE, Allegra; CHERRY, Rich; PROCTOR, Nancy; SAMIS, Peter. Getting On (not Under) the Mobile 2.0 Bus: Emerging Issues in the Mobile Business Model. Museums and the Web 2011 Conference. Philadelphia, PA, USA. Abril, 2011. Disponível em:

<www.museumsandtheweb.com/mw2011/papers/getting_on_not_under_the_mobile_20_bus>

CAIRNS, Susan. Tag! You're It! What Value Do Folksonomies Bring To The Online Museum Collection? Museums and the Web 2011 Conference. Philadelphia, PA, USA. Abril, 2011. Acesso em maio/2013. Disponível em:

<www.museumsandtheweb.com/mw2011/papers/tag_youre_it_what_value_do_folksonomies_bring >. 
CANCLINI, Néstor García. Lectores, espectadores e internautas. Barcelona, España: Editoral Gedisa, 2007.

CASTELLS, Manuel. Museums in the information era: cultural connectors of time and space. In: Parry, Ross (ed.) Museums in a age digital. USA: Routledge, 2010, p.427-434.

CHAE, Gunho; KIM, Jungwha. Can Social Tagging Be a Tool to Reduce the Semantic Gap between Curators and Audiences? Museums and the Web 2011 Conference. Philadelphia, PA, USA. Abril, 2011. Disponível em: $<w w w . m u s e u m s a n d t h e w e b . c o m / m w 2011 /$ programs/can_social_tagging_be_a_tool_to_reduce_the_s $>$.Acesso em maio/2013.

FAZENDO ARTE NO PINTEREST. Revista Status, online, 11 jul. 2012. Disponível em: <www.revistastatus.com.br/2012/07/11/fazendo-arte-no-pinterest>. Acesso em julho/2013.

FLUSSER, Vilém. O mundo codificado - por uma filosofia do design e da comunicação. São Paulo, Brasil: Cosac Naify, 2007.

FOST, Dan. Where neo-nomads' ideas percolate - New 'bedouins' transform a laptop, cell phone and coffee house into their office. San Francisco Chronicle online, 1 mar. 2007. Acesso em jul/2013. Disponível em: $<w w w . s f g a t e . c o m / d e f a u l t / a r t i c l e / W H E R E-N E O-N O M A D S-I D E A S-P E R C O L A T E-N e w-2610920 . p h p>$

GABRIEL, Martha. Tecnologias Móveis: Amigos ou Inimigos Disfarçados? In: Apropriações do (In) Comum - Espaço Público e Privado em Tempos de Mobildade, E-Book, Org: G. Beiguelman, Lucas Bambozzi, Marcus Bastos e Rodrigo Minelli, mai/2009. p. 65-77.

GRAHAM, Beryl; COOK, Sarah. Rethinking curating - Art after new media. Cambridge: The MIT Press, 2010.

HARTLEY, John. Utilidades do YouTube: alfabetização digital e a expansão do conhecimento. In: Burguess, Jean; Green, Joshua. YouTube e a revolução digital. São Paulo, Aleph, 2009. p. 165-186.

HUHTAMO, Erkki. On the origins of the virtual museum. In: Parry, Ross (ed.) Museums in a age digital. USA: Routledge, 2010, 121-135.

JENKINS, Henry. O que aconteceu antes do YouTube? In: Burguess, Jean; Green, Joshua. YouTube e a revolução digital. São Paulo, Aleph, 2009. p. 143-164.

LEMOS. André. Cidade e Mobilidade. In: Apropriações do (In) Comum - Espaço Público e Privado em Tempos de Mobildade, E-Book, Org: G. Beiguelman, Lucas Bambozzi, Marcus Bastos e Rodrigo Minelli, mai/2009. p. 43-59.

MAGENTA, Matheus. Google Art Project libera visita virtual à Pinacoteca e ao MAM. Folha online, 03 abr. 2012. Disponivel em: <www.folha.uol.com.br/ilustrada/1071082-google-art-project-libera-visita-virtual-a-pinacoteca-eao-mam.shtml>. Acesso em abril/2012.

MALRAUX, Andre. O museu imaginário. Lisboa: Edições 70, 2000.

McLUHAN, Marshall. Os meios de comunicação como extensão do homem. São Paulo: Cultrix, 1964.

A galáxia de Gutenberg: a formação do homem tipográfico. São Paulo: Companhia Editora Nacional, 1972.

MILLER, Claire Cain. Social Media as Inspiration and Canvas. The New York Times online, 16 mar. 2011. Disponível em: <www.nytimes.com/2011/03/17/arts/design/flickr-photos-and-vimeo-videos-as-artwork.html>. 
MÜLLER, Klaus. Museums and virtuality. In: Parry, Ross (ed.) Museums in a age digital. USA: Routledge, 2010, p. 295-305.

PAUL, Christiane. Challenges for a Ubiquitous Museum. In: From the White Cube to the Black Box and Beyond curatorial models for digital art. 2008, p.53-75.

REALIDADE AUMENTADA NA ARTE. O Globo online. Disponível em:

<www.oglobo.globo.com/infograficos/realidade-aumentada-arte>. Acesso em julho/2013.

RUSSO, Angelina; WATKINS, Jerry. Digital cultural communication: audience and remediation. In: Theorizing digital cultural heritage - a critical discourse. (Ed.) Cameron, Fiona; Kenderdine, Sarah. Cambridge: The MIT Press, 2007, p. 149-164.

SABBAGH, Karim. ACKER, Olaf. KARAM, Danny. RAHBANI, Jad. Designing the Transcendent Web The Power of Web 3.0. (C) 2011 Booz \& Company Inc. 13 p.

STUEDAHL, Dagny; SMORDAL, Ole. Re-thinking museum assemblies. Universidade de Oslo, Noruega, 2011.12 p. Disponível em: <www.academia.edu>. Acesso em maio/2013.

SVILICIC, Niksa. Creation and Typology Definition of the Museum on the Internet. Croatian Audiovisual Center, Zagreb, Croácia, 2010. 8 p. Disponível em: <www.academia.edu>

SZÁNTO, András. Time to lose control: museums have made great strides in adapting to the digital age but they need to go much further. Art Basel Miami Beach daily edition, 2 dez. 2010. Disponível em: $<$ www.theartnewspaper.com/articles/Time+to+lose+control/22092>.

TEDESCHI, Bob. Apps as Tour Guides Through New York Museums, Step by Step. The New York Times online, 8 set. 2010. Disponível em: <www.nytimes.com/2010/09/09/technology/personaltech/09smart.html? $r=2 \& e m c=e t a 1 \&$

\section{INTERNET:}

CLEVELAND HISTORICAL. Disponível em: <www.clevelandhistorical.org>. Acesso em julho/2013.

DELICIOUS. Disponível em: <www.delicicous.com>. Acesso em jul/2013.

DIA CENTER FOR THE ARTS. Disponível em: <www.diacenter.org>. Acesso em jul/2012.

ERA VIRTUAL MUSEUS. Disponível em: <www.eravirtual.org>. Acesso em maio/2013.

E.SPACE. Disponível em: <www.sfmoma.org/espace/espace overview.html>. Acesso pelo Wayback Machine: $<$ www.archive.org $>$. Acesso em jul/2011.

FACEBOOK. Disponível em: <www.facebook.com>. Acesso em jul/2013.

FILIPPO INNOCENTI. Disponível em: <www.filippoinnocenti.com>. Acesso em jul/2013.

FLICKR. Disponível em: <www.flickr.com>. Acesso em jul/2013.

GOOGLE ART PROJECT. Disponível em: <www.googleartproject.com>. Acesso em jul/2012.

GUGGENHEIM MUSEUM. Disponível em: <www.guggenheim.org>. Acesso em jun/2013. 
LUMINARE. Direção: John Sanborn e Dean Winkler. (Vídeo, 6'54", 1986). Disponível em:

$<$ www.youtube.com/watch?V=8Ip3yC2KdpU>. Acesso em junho/2013.

MAC NITERÓI. Disponível em: <www.macniteroi.com.br>. Acesso em jul/2012.

MAC-USP. Museu de Arte Contemporânea de São Paulo. Disponível em: <www.mac.usp.br>. Acesso em jul/2011.

MASP - Museu de Arte de São Paulo Assis Chateaubriand. Disponível em: <www.masp.art.br>. Acesso em jul/2013.

MOCA. MUSEUM OF COMPUTER ART. Disponível em: <www. museumofcomputerart.org>. Acesso em jun/2013.

MOMA. Museum of Modern Art of New York. Disponível em: <www.moma.org>. Acesso em jul/2012.

MUSEU DA PESSOA. Disponível em: <www.museudapessoa.net>. Acesso em julho/2012.

MUSEU VIRTUAL PARA A ARTE COMPUTACIONAL. Disponível em: <www.arte.unb.br/museu/museu.htm>. Acesso em jul/2012.

MUSEUMS AND THE WEB. Disponível em: <www.museumsandtheweb.com>. Acesso em maio/2013.

MUSEUMS WITH NO FRONTIERS. Disponível em: <www.discoverislamicart.org>. Acesso em jul/2011.

MUVA. MUSEU VIRTUAL DE ARTES. Disponível em: <http://muva.elpais.com.uy> . Acesso em maio/2013.

ONE HUNDRED BOXES. Disponível em: <www.onehundredboxes.com>. Acesso em jul/2013.

PINTEREST. Disponível em: <http://pinterest.com>. Acesso em jul/2013.

SFMOMA - San Francisco Museum of Modern Art. Disponível em: <www.sfmoma.org>. Acesso em jul/2012.

STREAMING MUSEUM. Disponível em: <www.streamingmuseum.org>. Acesso em maio/2013.

TATE MODERN MUSEUM. Disponível em: <http://tate.org.uk>. Acesso em jul/2012.

THE BIG INTERNET MUSEUM. Disponível em: <www.thebiginternetmuseum.com>. Acesso em maio/2013.

THE FRICK COLLECTION. Disponível em: <www.frick.org>. Acesso em jun/2013.

THE GALLERY OF LOST ART. Disponível em: <www.galleryoflostart.com>. Acesso em jul/2013.

THE MINI MUSEUM OF XXI CENTURY ARTS. Disponível em: <http://minimuseum.linkartcenter.eu>. Acesso em $\mathrm{jul} / 2013$.

THE MUSEUM OF ME. Disponível em: <www.intel.com/museumofme>. Acesso em julho/2011.

THE MUSEUM OF ONLINE MUSEUMS. Disponível em: <www.coudal.com/moom>. Acesso em jul/2013.

THE WIDGET ART GALLERY. Disponível em: <www.chiarapassa.it/TheWidgetArtGallery.html>. Acesso em jul/2013.

TOURSPHERE. Disponível em: <www.toursphere.com>. Acesso em julho/2013.

TWITTER. Disponível em: <www.twitter.com>. Acesso em jul/2013.

UBUWEB. Disponível em: <www.ubuweb.com>. Acesso em jul/2013.

VIDEOMUSEUM. Disponível em: <www.videomuseum.fr>. Acesso em: jul/2011. 
WEB GALLERY OF ART. Disponível em: <www.wga.hu>. Acesso em: jun/2013.

WIKIPEDIA. Disponível em: <www.wikipedia.org>. Acesso em: jul/2011.

YOUTUBE. Disponível em: <www.youtube.com>. Acesso em: jul/2013.

ZKM MEDIA MUSEUM. Disponibilizado em: http://on1.zkm.de/zkm/e/institute/medienmuseum. Acesso jul/2012.

\section{BIBLIOGRAFIA ADICIONAL:}

\section{TEXTOS:}

ALTSHULER, Bruce. Curadoria, exposição e educação no museu de arte. In: Sobre museus. (Ed.) GONÇALVES, Lisbeth Rebollo. São Paulo: MAC-USP, 2010, p. 43-65.

AMAZONAS J.R.A.; BELLINETTI J.V.; FERNANDES, J.N.; MARÃO, G.A.; A importância da internet das coisas para o Brasil. Fórum de Competitividade em loT no Brasil, 2012. Disponível em: www.iotbrasil.com.br. Acesso ago/2012.

AS CAMADAS DA INTERNET. Folha de São Paulo. São Paulo, 5 set. 2011. Link, Caderno L, p.1-6.

BOWEN, Jonathan P; FANTONI, Silvia F. Multimedia Tours in Museums: Reflections from ten years of practice. França/Reino Unido, 2008. 15 p. Disponível em: <www.academia.edu>.

CASTELLS, Manuel. A era da intercomunicação. 2006. Disponível em: <www.diplomatique.org.br/acervo.php? $\mathrm{id}=1915>$. Acesso em: maio/2013.

CHARLESWORTH, JJ. Curating doubt. In: (Ed.) Rugg, Judith; Sedgwick, Michèle. Issues in curating contemporary arts and performance. Bristol: Intellect Books, 2007, p. 91-99.

COOK, Sarah. Online activity and offline community: cultural institutions and new media art. In: Theorizing digital cultural heritage - a critical discourse. (Ed.) Cameron, Fiona; Kenderdine, Sarah. Cambridge: The MIT Press, 2007, p. 113-132.

CUERO, Raquel. Redes sociais na internet. Porto Alegre: Editora Sulina, 2010.

CYPRIANO, Fabio. Pinacoteca and MAM join Google Art. Folha Online, março/2012. Disponível em: $<$ www.folha.uol.com.br/internacional/en/culture/1069989-pinacoteca-and-mam-join-google-art.shtml >. Acesso em: julho/2012.

DENNIS, Kingsley. Time in the Age of Complexity. TIME \& SOCIETY. 2007; 16; 139. Disponível em: <http://tas.sagepub.com/cgi/content/abstract/16/2-3/139>. Acesso em: julho/2012.

DONAHUE, Ryan. Archiving Flickr and Other Websites of Interest to Museums. Museums and the Web 2012. Conference. San Diego, CA, USA. Abril, 2012. Acesso em: julho/2013. Disponível em: <www.museumsandtheweb.com/mw2012/papers/archiving_flickr_and_other_websites_of_interes>.

ECO, Humberto. Como se faz uma tese. São Paulo: Perspectiva, 2009. (22a Ed.) 
FALCÃO, Eduardo; MACHADO, Liliane. Museu 3I: Publicação e Visitação Online de Acervos Tridimensionais. Universidade Federal da Paraíba - CCEN. Artigo no Scribd.

FORTE, M; DELL'UNTO, N; DI FRANCO, PDG; GALEAZZI, F; LIUZZA, C; PESCARIN, S. The virtual museum of the Western Han Dynasty: 3D documentation and interpretation. University of California, Merced / Stanford University / Istituto per le Tecnologie Applicate ai Beni Culturali. Roma, 2010. 5 p. Disponível em: < $\underline{w w w . a c a d e m i a . e d u>. ~}$

FREIRE, Cristina. Do perene ao transitório: novos paradigmas para o museu de arte contemporânea. In: Magalhães, Ana Gonçalves (org.) I Seminário internacional de arquivos de museus e pesquisa. São Paulo: MAC-USP, 2010, p. 93-100.

FUNARO, Vânia Martins Bueno de Oliveira (coord.) [et al.] Diretrizes para apresentação de dissertações e teses da USP: documento eletrônico e impresso Parte IV (Vancouver); São Paulo: Sistema Integrado de Bibliotecas da USP, 2009, 96 p. (2a ed.)

GANSALLO, Matthew. Curating new media. In: Parry, Ross (ed.) Museums in a age digital. USA: Routledge, 2010, p. 345-350.

GHIANNI, Tim. Museu online mostra cartas do assassino de Martin Luther King Jr. Reuters, 31 mar. 2011. Disponível em: <http://br.noticias.yahoo.com/museu-online-mostra-cartas-assassino-martin-luther-king-20110331-140457813.html>. Acesso em abril/2011.

GOOGLE ART PROJECT VS DELIRIOUS MUSEUM. 31 maio 2011 (?). Acesso em maio/2013. Disponível em: $<w w w$.museumcultures.wordpress.com/2011/05/31/google-art-project-vs-the-delirious-museum>.

GOTVED, Stine. Time and space in cyber social reality. NEW MEDIA \& SOCIETY. 2006. Vol8(3):467-486.

GRAU, Oliver. Arte virtual - da ilusão à imersão. São Paulo: Unesp-Senac, 2007.

GUZMÁN FRANCO, María Dolores. "Los lenguajes ON LINE". In: La galaxia digital - Lenguaje y cultura sin fronteras en la era de la información. (Org.) Prado Aragonés, Josefina; Pérez Rodríguez, María Amor; Galloso Camacho, María Victoria; Andalucía, España: Grupo Editorial Universitario, 2003, 109-120.

HEATH, Christian; LEHN, Dirk Vom. Interactivity and collaboration: new forms of participation in museums, galleries and science centres. In: Parry, Ross (ed.) Museums in a age digital. USA: Routledge, 2010, 266-280.

HERCULANO, Mônica. Instituto Brasileiro de Museus completa dois anos. Cultura e Mercado, online, 20 jan. 2011. Disponível em: <www.culturaemercado.com.br/noticias/politica/instituto-brasileiro-de-museus-completa-doisanos>. Acesso em jan/2011.

HIGHLIGHTS IN CONSERVATION OF TIME-BASED MEDIA ART. Guggenheim.org, 1 ago. 2012. Disponível em: $<$ www.guggenheim.org/new-vork/press-room/news/4790-guggenheimorg-highlights-conservation-of-time-basedmedia-art>. Acesso em jul/2012.

HYLTON, Richard. Thoughts on curating. In: (Ed.) Rugg, Judith; Sedgwick, Michèle. Issues in curating contemporary arts and performance. Bristol: Intellect Books, 2007, p. 113-127.

INTERNET DAS COISAS - INTERNET OF THINGS (IOT). Fórum de Competitividade em loT no Brasil, 2012. Disponível em: $<\underline{w w w}$.iotbrasil.com.br $>$. Acesso em ago/2012. 
KÄLLMAN, Rolf. Cultural Heritage 2.0 and beyond. (apresentação de slides) Swedish National Heritage Board, ICLAM, 2011. 38 p. Disponível em: <www.slideshare.net $>$.

KELLY, Lynda. Museum 3.0: informal learning \& social media. (apresentação de slides) Social Media and Cultural Communication Conference. Sydney, Austrália. 29 fev. 2008 . 17 p. Disponível em: <www.slideshare.net>.

KENNEDY, Bryan; SHERMAN, Rose. Social Networking and Web-Based Communities for Learning. (apresentação de slides) Science Museum of Minnesota / Minnesota Historical Society. 32 p. Disponível em: <www.slideshare.net>.

LÉVY, Pierre. Cibercultura. São Paulo: Editora 34, 1999.

LEWIS, Peter. The role of marketing. In: Forward planning- a handbook of business, corporate and development planning for museums and galleries. (Ed.) Ambrose, Timothy; Runyard, Sue. London: Routledge, 1993, p. 26-31.

MANASSEH, Cyrus. The problematic of vídeo art in the museum. New York: Cambria Press, 2009.

MOLINA, Fernando. USP desenvolve projetos ligados à "Internet das Coisas". USP Online. São Paulo, 31 jul. 2012. Tecnologia. Acesso em ago/2012.

MORETTI, Franco. MOMA: The capitulation. In: Harrison, Charles \& Wood, Paul (ed.). Art in theory - 1900/2000 an anthology of changing ideias. USA: Blackwell, 2002, p.1183-1187.

MORRISON, Alex. App Publishing Opportunities for Museums. (apresentação de slides) Cogapp. 16 Nov. 2010. 115 p. Disponivel em: <www.slideshare.net $>$.

MUSEUMS \& MOBILE IN 2012 - An analysis of the Museums \& Mobile Survey 2012 responses. (apresentação de slides). Pocket-Proof \& LearningTimes, fev. 2012. 60 p. Disponível em: <www.slideshare.net>.

MUSEUS E INTERNET (parte 1). Disponível em: <www.culturaempauta.com.br/?p=1389>. Acesso em jul/2011.

NEW ART TRUST EXPANDS HOLDINGS. Artdaily.org, 13 jan. 2007. Disponível em: $<w w w$.artdaily.com/news/18873/New-Art-Trust-Expands-Holdings>.

PARRY, Ross; ARBACH, Nadia. Localized, personalized, and constructivist: a space for online museum learning. In: Theorizing digital cultural heritage - a critical discourse. (Ed.) Cameron, Fiona; Kenderdine, Sarah. Cambridge: The MIT Press, 2007, p. 281-300.

PARRY, Ross (ed.) Museums in a age digital. USA: Routledge, 2010.

PARRY, Ross. Closing keynote. (apresentação de slides). DISH2009 . Rotterdam, Holanda. 18 set. 2009. 110 p. Disponível em: <www.slideshare.net $>$.

PAUL, Christiane. Challenges for a Ubiquitous Museum. In: From the White Cube to the Black Box and Beyond curatorial models for digital art. 2008, p.53-75.

PIMENTEL, Lucia Gouvêa. Tecnologias contemporâneas e o ensino da arte. In: Inquietações e mudanças no ensino da arte. (Org.) Barbosa, Ana Mae. São Paulo: Cortaz Editora, 2008, 4ạ ed, 113-121.

PORTELLA, Adriana. Aprendizagem da arte e o museu virtual do projeto portinari. In: Inquietações e mudanças no ensino da arte. (Org.) Barbosa, Ana Mae. São Paulo: Cortaz Editora, 2008, 4aed, 123-137.

PRADO, Gilbertto. Arte telemática: dos intercâmbios pontuais aos ambientes virtuais multiusuário. Itaú Cultural: São Paulo, 2003. 
PROCTOR, Nancy. Mobile is Social Media: In the Museum as Distributed Network. (apresentação de slides) Design for Mobile, Chicago, USA, 22 set. 2010 . 46 p. Disponível em: <www.slideshare.net>.

PROCTOR, Nancy. Mobile as Radical Social Media: In the Museum of the 21st Century. (apresentação de slides) Smithsoniam Institution, USA, 28 out. 2011. 39 p. Disponível em: <www.slideshare.net>.

RODRIGUES, Bruno César. Reflexões acerca do museu virtual de arte e seu papel como mediador cultural. Tese de mestrado, ECA-USP, 2011.

RUSH, Michael. Novas mídias na arte contemporânea. São Paulo: Martins Fontes, 2006.

RUSSO, Angelina; WATKINS, Jerry; KELLY, Lynda; CHAN, Sebastian. How will social media affect museum communication? In: Proceedings Nordic Digital Excellence in Museums (NODEM), Oslo, Noruega, 2006.

SANDVIK, Kjetil. Museums, digital media and a perpetual beta way of communicating. 29 p. Disponível em: $<$ www.academia.edu>.

SEVERINO, Antonio Joaquim. Metodologia do trabalho científico. São Paulo: Cortez Editora, 2007. (23a Ed.)

SHERMAN, Rose. Museum Social Media Strategic Planning Worksheet. (apresentação de slides). Minnesota Historical Society. Set. 2009. 5 p. Disponível em: <www.slideshare.net> .

SOLON, Marcos. Os museus e a cultura digital: a virtualização dos espaços expositivos. In: A arquitetura museológica contemporânea e a sua relação com a cidade, a arte e as novas mídias. São Paulo, 2013. Disponível em: <www.transmuseus.net>. Acesso em: abril/2013.

SURVEYING TECHNOLOGY: A MUSEUM EXPERIMENT. Museums in Conversation Conference, 14-16 abr. 2013. Syracuse, NY, USA. Disponível em: <www.engagingyouraudience.files.wordpress.com/2013/04/surveyingtechnology.pdf>. Acesso em maio/2013.

VOSS, Jon. Radically Open Cultural Heritage Data on the Web. Museums and the Web 2012 Conference. San Diego, CA, USA. Abril, 2012. Acesso em jul/2013. Disponível em: <www.museumsandtheweb.com/mw2012/papers/radically open cultural heritage data on the w>

WALLIS, Brian (ed.) Art after modernism: rethinking representation. New York: New Museum of Contemporary Art, 1984.

WALSH, Peter. Rise and fall of the post-photographic museum: technology and the transformation of art. In: Theorizing digital cultural heritage - a critical discourse. (Ed.) Cameron, Fiona; Kenderdine, Sarah. Cambridge: The MIT Press, 2007, p. 19-34.

WYTHE. Deborah. Reinstrumentalização dos arquivos de museus para o século XXI: Novas coleções, novos públicos, novas parcerias, novas tecnologias. In: Magalhães, Ana Gonçalves (org.) I Seminário internacional de arquivos de museus e pesquisa. São Paulo: MAC-USP, 2010, p. 28-58.

YAMAMOTO, Patricia. Os museus de arte contemporânea na www: novas formas de ampliação do acesso intelectual. Tese de mestrado, ECA-USP, 2001. 


\section{INTERNET:}

BRITISH MUSEUM. Disponível em: <www.britishmuseum.org>. Acesso em jul/2012.

CECCONI, Carlo. TRACCE - museum of a flâneur. Itália, fev. 2012. Disponível em: <www.carlocecconitracce.blogspot.com.br>. Acesso em jun. 2012.

CENTRE POMPIDOU. Disponível em: <www.centrepompidou.fr $>$.

COMMUNITY MUSEUM PROJECT. Disponível em: <www.hkcmp.org/cmp>. Acesso em maio/2013.

IBRAM - INSTITUTO BRASILEIRO DE MUSEUS. Disponível em: <www.ibram.gov.br>. Acesso em jul/2012.

MAM - MUSEU DE ARTE MODERNA DE SÃO PAULO. Disponível em: <www.mam.org.br>. Acesso em jul/2012.

MOM - MUSEUM OF MUSEUM. Disponível em: <www.museumofmuseum.com>

MUSEU AFRO-BRASIL. Disponível em: <www.museuafrobrasil.org.br>. Acesso em jul/2012.

MUSEU VIRTUAL RTP. Disponível em: <http://museu.rtp.pt> . Acesso em maio/2013.

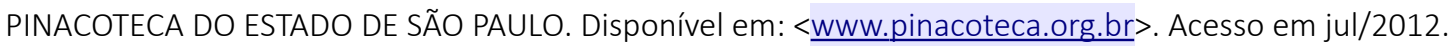


JULHO
2013 